\title{
Calculation of \\ Releases of Radioactive Materials \\ in Gaseous and Liquid Effluents \\ from Pressurized Water Reactors
}

PWR-GALE Code

Manuscript Completed: March 1985

Date Published: April 1985

T. Chandrasekaran, J. Y. Lee, C. A. Willis

Division of Systems Integration

Office of Nuclear Reactor Regulation

U.S. Nuclear Regulatory Commission

Washington, D.C. 20555

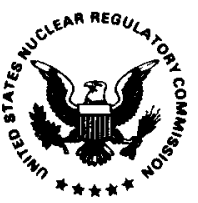




\section{DISCLAIMER}

This report was prepared as an account of work sponsored by an agency of the United States Government. Neither the United States Government nor any agency Thereof, nor any of their employees, makes any warranty, express or implied, or assumes any legal liability or responsibility for the accuracy, completeness, or usefulness of any information, apparatus, product, or process disclosed, or represents that its use would not infringe privately owned rights. Reference herein to any specific commercial product, process, or service by trade name, trademark, manufacturer, or otherwise does not necessarily constitute or imply its endorsement, recommendation, or favoring by the United States Government or any agency thereof. The views and opinions of authors expressed herein do not necessarily state or reflect those of the United States Government or any agency thereof. 


\section{DISCLAIMER}

Portions of this document may be illegible in electronic image products. Images are produced from the best available original document. 


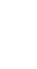




\section{ABSTRACT}

This report revises the original issuance of NUREG-0017, "Calculation of Releases of Radioactive Materials in Gaseous and Liquid Effluents from Pressurized Water Reactors (PWR-GALE-Code)" (April 1976), to incorporate more recent operating data now available as well as the results of a number of in-plant measurement programs at operating pressurized water reactors. The PWR-GALE Code is a computerized mathematical model for calculating the releases of radioactive material in gaseous and liquid effluents (i.e., the gaseous and liquid source terms). The U.S. Nuclear Regulatory Commission uses the PWR-GALE Code to determine conformance with the requirements of Appendix I to 10 CFR Part 50. 
ABSTRACT .......................

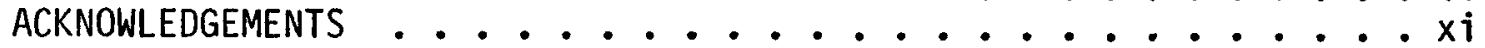
EXECUTIVE SUMMARY ................................. CHAPTER 1. PWR-GALE CODE

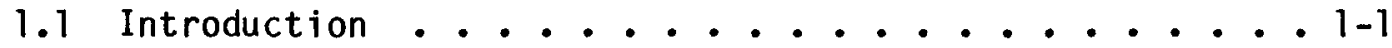

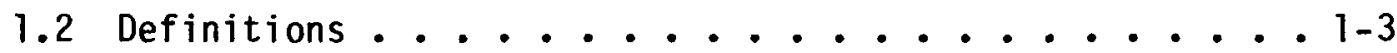

1.3 Gaseous Source Terms .............. 1-6

1.4 Liquid Source Terms .............. . . . . . .

1.5 Instructions for Completing PWR-GALE Code Input Data Cards ....................... 1-8

1.5.1 Parameters Included in the PWR-GALE Code ... 1-8

1.5.2 Parameters Required for the PWR-GALE Code ... 1-13

CHAPTER 2. PRINCIPAL PARAMETERS USED IN PWR SOURCE TERM CALCULATIONS AND THEIR BASES

2.1 Introduction ................. 2-1

2.2 Principal Parameters and Their Bases ....... 2-1

2.2.1 Thermal Power Level ............ 2-1

2.2.2 Plant Capacity Factor ........... 2-1

2.2.3 Radionuclide Concentrations in the Primary and

Secondary Coolant ......... 2-2

2.2.4 Iodine Releases from Building Ventilation

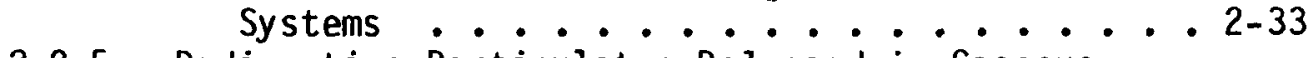

2.2.5 Radioactive Particulates Released in Gaseous

2.2 .6 Effluents ........... 2-40

2.2.6 Noble Gas Releases from Building Ventilation

2.2.7 Steam Generator Biowdown Fiash $\dot{T}^{\circ} \dot{k}$ Vent $\cdots \cdot 2-42$

2.2.8 Iodine Releases from Main Condenser Air Ejector

2.2 .9 Containment Purge Frequency . . . . . 2-48

2.2.10 Containment Internal Cleanup System . . . 2-55

2.2.11 Radioiodine Removal Efficiencies for Charcoal

Adsorbers and Particulate Removal

Efficiencies for HEPA Filters .... 2-56

2.2.12 Waste Gas System Input Flow to Pressurized

Storage Tanks ....... 2- 2-57

2.2.13 Holdup Times for Charcoal Delay System .... 2-60

2.2.14 Liquid Waste Inputs ........... 2-61

2.2 .15 Detergent Waste ............. 2-61

2.2.16 Chemical Wastes from Regeneration of

Condensate Demineralizers . . . . 2-68 
Page

2.2.17 Tritium Releases ............ 2-68

2.2.18 Decontamination Factors for Demineralizers . . 2-77

2.2.19 Decontamination Factors for Evaporators . . . 2-79

2.2.20 Decontamination Factors for Liquid Radwaste

Filters ............ 2-80

2.2.21 Decontamination Factors for Reverse Osmosis . 2-80

2.2.22 Guideline for Calculating Liquid Waste Holdup

Times ................ 2-81

2.2.23 Adjustment to Liquid Radwaste Source Terms for

Anticipated Operational 0ccurrences . . 2-86

2.2.24 Atmospheric Steam Dump . . . . . . . . 2-89

2.2.25 Carbon-14 Releases ........... 2- 2-90

2.2.26 Argon-41 Releases .......... 2-93

CHAPTER 3. INPUT FORMAT, SAMPLE PROBLEM, AND FORTRAN LISTING

OF THE PWR-GALE CODE

3.1 Introduction .................. 3-

3.2 Input Data . . . . . . . . . 3-1

3.2.1 Explanation of the Inputs for the Sample Problem . 3-1

3.2.2 Input Coding Sheets .......... 3-5

3.3 Sample Problem -- Input and Output ....... 3-5

3.4 Listing of PWR-GALE Code ............ 3-5

3.4.1 Nuclear Data Library ........... 3-5

3.4 .2 FORTRAN Program Listing ........ 3-15

CHAPTER 4. DATA FOR RADIOACTIVE SOURCE TERM CALCULATIONS

FOR PRESSURIZED WATER REACTORS

4.1 General ................. 4-

4.2 Primary System .............. . . . . 1

4.3 Secondary System .............. 4-1

4.4 Liquid Waste Processing Systems ......... 4-2

4.5 Gaseous Waste Processing System ........ 4-3

4.6 Ventilation and Exhaust Systems ........ 4-3

APPENDIX A

Liquid Source Term Calculational Procedures for Regenerant Wastes from Demineralizers Other Than Condensate

Demineralizers ..................... 


\section{LIST OF TABLES}

$\underline{\text { Table }}$

Page

$1-1$

Radioiodine Releases from Building Ventilation Systems

Prior to Treatment ............. 1-9

1-2 Radioactive Particulate Releases from Building

Ventilation Systems Prior to Treatment ....... 1-10

1-3 PWR Liquid Wastes ................ 1-18

1-4 Decontamination Factors for PWR Liquid Waste

Treatment Systems .............. . 1-21

1-5 Assigned Removal Efficiencies for Charcoal Adsorbers

for Radioiodine Removal .......... . . 1-29

2-1 Plant Capacity Factors at Operating PWR's . . . . . 2-3

2-2 Numerical Values - Concentrations in Principal Fluid Streams of the Reference PWR with U-Tube Steam Generators .............. 2-4

2-3 Numerical Values - Concentrations in Principal Fluid Streams of the Reference PWR with Once-Through Steam Generators ... . . . . . . . 2-6

2-4 Parameters Used to Describe the Reference Pressurized Water Reactor with U-Tube Steam Generators . . . . 2-8

2-5 Parameters Used to Describe the Reference Pressurized Water Reactor with Once-Through Steam Generators . . 2-9

2-6 Values Used in Determining Adjustment Factors for Pressurized Water Reactors .......... 2-10

2-7 Adjustment Factors for PWR's with U-Tube Steam Generators .............. 2-12

2-8 Adjustment Factors for PWR's with Once-Through Steam Generators ........... . . 2-13

2-9 Summary of Iodine-131 and Iodine-133 Primary Coolant Concentrations in PWR's......... 2-21

2-10 Summary of Radionuclide Primary Coolant Concentrations in PWR's ................. 2-22

2-11 Monthly Average Primary/Secondary Leakage . . . . . 2-26

2-12 Moisture Carryover in Recirculating U-Tube Steam Generators ........... 2- . . 32 
2-13 Annual Iodine Normalized Releases from Containment

Ventilation Systems.............. 2-34

2-14 Annual Iodine Normalized Releases from Auxiliary Bldg. Ventilation Systems . . . . . . . . . . 2-35

2-15 Annual Iodine Normalized Releases from Refueling Area Ventilation Systems ............ 2-36

2-16 Annual Iodine Normalized Releases from Turbine Building Ventilation Systems ........... . 2-37

2-17 Particulate Release Rate for Gaseous Effluents . . . 2-42

2-18 Measured Release Upstream of HEPA Filters Containment.............. 2-43

2-19 Measured Releases Upstream of HEPA Filters - Auxiliary Building ............... . . 2-44

2-20 Measured Releases Upstream of HEPA Filters - Fuel Pool Area................. 2-... 245

2-21 Measured Releases Upstream Filters - Waste Gas System ................... 2-46

2-22 Annual Iodine Normalized Releases from Main Condenser Air Ejector Exhaust . . . . . . . . . . 2-49

2-23 PWR Containment Purging and Venting Experience . . . 2-52

2-24 Waste Gas System Input Flow to Pressurized Storage

Tanks and PWR's Without Recombiners ........ 2-58

2-25 Waste Gas System Input Flow to Pressurized Storage

Tanks for PWR's with Recombiners ....... 2-59

2-26 PWR Liquid Wastes ............... 2-65

2-27 Calculated Annual Release of Radioactive Material in Untreated Detergent Waste.......... 2-67

2-28 Radionuclide Distribution of Detergent Waste . . . 2-69

2-29 Tritium Release Data from Operating PWR's with Zircaloy-Clad Fuels.............. 2-71

2-30 Tritium Release Rate from Operating PWR's as a Function of Number of Years of Operation ....... 2-75 
2-31 Tritium Release Rate from Operating PWR's - Percent of Total Tritium Released in Liquid Effluents... . 2-76

2-32 Distribution of Tritium Release in Gaseous Effluents • 2-78

2-33 Reverse Osmosis Decontamination Factors, Ginna Station . . . . . . . . . . 2-82

2-34 Reverse Osmosis Decontamination Factors, Point Beach ............. 2- . . . 83

2-35 Reverse Osmosis Decontamination Factors, H. B. Robinson No. 2 Station ....... 2-84

2-36 Expected Reverse Osmosis Decontamination Factors for Specific Nuclides . . . . . . . . 2-85

2-37 Frequency and Extent of Unplanned Liquid Radwaste Releases from Operating Plants ....... 2-88

2-38 Carbon-14 Release Data from Operating PWR's . . . . 2-91

2-39 Distribution of Carbon-14 Released in Gaseous Effluents.............. 2- . . . . 22

2-40 Summary of Argon-41 Releases for Operating PWR's

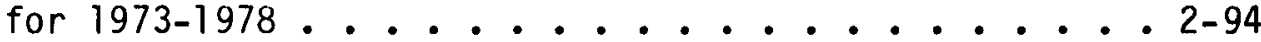




\section{LIST OF FIGURES}

Figure

2-1 Removal Paths for Pressurized Water Reactor with

U-Tube Steam Generators.......... 2-14

2-2 Removal Paths for Pressurized Water Reactor with Once-Through Steam Generators ......... 2-15

2-3 Krypton and Xenon $K$ Values as a Function of Reciprocal Temperature ......... 2-62

2-4 Effect of Moisture Content on the Dynamic Adsorption Coefficient ................. 2-63

2-5 Charcoal Moisture as a Function of Relative Humidity . . 2-64

3-1 Input Coding Sheets for Sample Problem . . . . 3-6

3-2 Printout of Input and Output for the Sample Problem . . 3-8

3-3 Program Listing for Gaseous Determination . . . . 3-16

3-4 Program Listing for Liquid Determination . . . . 3-26 


\section{ACKNOWLEDGMENTS}

Many individuals contributed to the preparation of Revision 1 of this document. In particular, R. L. Bangart and F. P. Cardile of the Nuclear Regulatory Commission, and A. E. Refre of the Philippine Atomic Energy Commission were the principal contributors. J. W. Mandler and F. Y. Tsang of EG\&G Idaho edited this revision and have incorporated the results of a number of in-plant measurement programs at operating pressurized water reactors under an INEL Technical Assistance contract to the Division of Systems Integration, U. S. Nuclear Regulatory Commission (FIN A-6460). The Revision 0 of this document was prepared by L. G. Bell, M. J. Bell, R. R. Bellamy, J. S. Boegli, W. C. Burke, F. P. Cardile, J. T. Collins, J. Y. Lee, P. G. Stoddart, W. D. Travers, and R. A. Weller of the Nuclear Regulatory Commission. 


\section{EXECUTIVE SUMMARY}

The average quantity of radioactive material released to the environment from a nuclear power reactor during normal operation including anticipated operational occurrences is called the "source term,"* since it is the source or initial number used in calculating the environmental impact of radioactive releases. The PWR-GALE (Pressurized Water Reactor - Gaseous and Liquid Effluents) Code is a computerized mathematical model for calcūlating the releases of radioactive material in gaseous and liquid effluents (i.e., the gaseous and liquid source terms) from pressurized water reactors. The calculations are based on data generated from operating reactors, field and laboratory tests, and plant-specific design considerations incorporated to reduce the quantity of radioactive materials that may be released to the environment during normal operation, including anticipated operational occurrences.

The U.S. Nuclear Regulatory Commission uses the PWR-GALE Code to determine conformance with the requirements of Appendix I to $10 \mathrm{CFR}$ Part 50 . The first issue of this NUREG report was published in April 1976. In order to use the best available data for improving the calculational models used by the Commission staff to determine conformance with Appendix I to 10 CFR Part 50, Revision 1 is being issued to update NUREG-0017. This revision incorporates more recent operation data now available and also incorporates the results of a number of in-plant measurement programs at operating pressurized water reactors.

Chapter 1 of this report gives a step-by-step procedure for using the PWR-GALE Code along with a description of the parameters which have been built into the Code for use with all PWR source term calculations. These parameters, which apply generically to all PWR's, have been incorporated into the Code to eliminate the need for their entry on input data cards. Other parameters are required to be entered on input cards used by the Code. Explanations of the data require, along with acceptable means for calculating such data, are given for each input data card.

Descriptions of the principal parameters used in source term calculations and explanations of the bases for each parameter are given in Chapter 2. The parameters have been derived from reactor operating experience where data were available. Where operating data were inconclusive or not available, information was drawn from laboratory and field tests and from engineering judgment. The bases for the source term parameters explain the reasons for choosing the numerical values listed. A list of references used in developing the parameters is also included. The source term parameters used are believed to provide a realistic assessment of reactor and radwaste system operation.

\# "Source term" as discussed in this report differs from "accident source term," which deals with potential releases resulting from nuclear reactor accidents. 
Chapter 3 contains sample input data together with an explanation of the input to orient the user in making the required entries. Also included is a listing of the input data for a sample problem, a discussion of the nuclear data library used, and a FORTRAN listing of the PWR-GALE Code.

Chapter 4 ists the information needed to generate source terms for PWR's. The information is proved by the applicant and is consistent with the contents of the Safety Analysis Report (ER) of the proposed PWR. This information constitutes the basic data required in calculating the releases of radioactive material in liquid and gaseous effluents. 


\section{CHAPTER 1. PWR-GALE CODE}

\subsection{INTRODUCTION}

In promulgating Appendix I to 10 CFR Part 50, the U. S. Nuclear Regulatory Commission indicated its desire to use the best available data for improving the calculational models used by the Commission Staff to determine conformance with the requirements of the regulation. The first issue of this NUREG Report was published in April 1976. Revision 1 is being issued to update NUREG-0017 by incorporating more recent operating data now available and also by incorporating the results of a number of in-plant measurement programs at operating pressurized water reactors (PWR's).

The PWR-GALE (Pressurized Water Reactor - Gaseous and Liquid Effluents) Code is a computerized mathemat $\overline{i c a l}$ model for $\bar{c} \bar{a} l c u l a t i \bar{n} g$ the releases of radioactive material in gaseous and liquid effluents from pressurized water reactors. The calculations are based on data generated from operating reactors, field and laboratory tests, and plant-specific design considerations incorporated to reduce the quantity of radioactive materials that may be released to the environment during normal operation, including anticipated operational occurrences.

The average quantity of radioactive material released to the environment from a nuclear power reactor during normal operation is called the "source term" since it is the source or initial number used in calculating the environmental impact of radioactive releases. The calculations performed by the PWR-GALE Code are based on (1) American Nuclear Society (ANS) 18.1 Working Group recommendations (Ref. 1) for adjustment factors, (2) the release and transport mechanisms that result in the appearance of radioactive material in liquid and gaseous waste streams, (3) plant-specific design features used to reduce the quantities of radioactive materials ultimately released to the environment, and (4) information received on the operation of nuclear power plants.

In a PWR, primary coolant water circulates through the reactor core where it removes the heat from the fuel elements. In the steam generators, heat from the pressurized primary coolant water is transferred to the secondary coolant water to form steam. The steam expands through the turbine and is then condensed and returned to the steam generators. The primary coolant water flows back to the reactor core. The principal mechanisms that affect the concentrations of radioactive materials in the primary coolant are: (1) fission product leakage to the coolant from defects in the fuel cladding and fission product generation in tramp uranium, (2) corrosion products activated in the core, (3) radioactivity removed in the reactor coolant treatment systems, and (4) activity removed because of primary coolant leakage. These mechanisms are described briefly in the following paragraphs. 
The primary coolant is continuously purified by passing a side stream through filters and demineralizers in the reactor coolant treatment systems (RCTS). It is necessary to maintain the purity of the primary coolant to prevent fouling of heat transfer surfaces and to keep releases to the environment as low as is reasonably achievable. Chemicals are added to the primary coolant to inhibit corrosion and/or improve fuel economy. Lithium hydroxide is added for $\mathrm{pH}$ control to reduce corrosion.

Water decomposes into oxygen and hydrogen as a result of radiolysis. The control of oxygen concentration in the primary coolant is important for corrosion control. Hydrogen, added to the primary coolant as dissolved free hydrogen, tends to force the net reaction toward the recombination of hydrogen and oxygen to water at an overall rate sufficient to maintain low primary coolant oxygen concentrations.

Boron is added to the primary coolant as a neutron absorber (shim control). As the fuel cycle progresses, boron is removed from the primary coolant through the RCTS loop (shim bleed). The shim bleed is processed through an evaporator, and the boron in the evaporator bottoms is either reused or packaged as solid waste. The evaporator distillate may be recycled to the reactor coolant system as makeup water or discharged to the environment.

Radioactive gases stripped from the primary coolant by degassification are normally collected in pressurized storage tanks and held for radioactive decay prior to recycle or release to the environment. Alternative treatment methods include charcoal delay systems and cryogenic distillation.

Because of leakage through valve stems and pump shaft seals, some coolant escapes into the containment and the auxiliary buildings. A portion of the leakage evaporates, thus contributing to the gaseous source term, and a fraction remains as liquid, becoming part of the liquid source term. The relative amount of leakage entering the gaseous and liquid phases is dependent upon the temperature and pressure at the point where the leakage occurs. Most of the noble gases enter the gas phase, whereas iodine partitions into both phases.

Leakage of primary coolant into the secondary coolant in the steam generator is the only source of radioactivity in the secondary coolant system. Water or steam leakage from the secondary system provides significant inputs to the liquid and gaseous radwaste treatment systems. Steam leakage may be significant to the gaseous source term since the radioactivity released remains in the gas phase.

In a recirculating $U$-tube steam generator, the nonvolatile radionuclides leaking from the primary coolant concentrate in the liquid phase in the steam generator. The degree of concentration is controlled by the steam generator blowdown rate and condensate demineralizer flow rate.

Since there is no liquid reservoir in a once-through steam generator, the primary coolant leakage boils to steam when it enters the secondary 
side of the steam generator. Secondary coolant purity is maintained by a condensate demineralizer system and there is no steam generator blowdown. The concentration of radioactivity in the secondary coolant is controlled by the condensate demineralizer flow rate.

Sources of radioactive wastes from the secondary system are the offgases from the turbine condenser, vent gases from the turbine gland seal, liquid and vent gases from the steam generator blowdown, and liquid and gaseous leaks into the turbine building. Liquid wastes also originate from the chemical regeneration of condensate demineralizers in feedwater/ condensate systems.

In this chapter, a step-by-step procedure for using the PWR-GALE Code is given along with a description of the parameters which have been built into the Code for use with all PWR source term calculations. These parameters, which apply generically to all PWR's, have been incorporated into the Code to eliminate the need for their entry on input data cards. other parameters are required to be entered on input data cards used by the Code. Explanations of the data required, along with acceptable means for calculating such data, are given for each input data card. Chapter 2 gives the principal source term parameters developed for use with the PWR-GALE Code and explains the bases for each parameter. Chapter 3 contains a sample data input sheet and a Fortran IV listing of the PWR-GALE Code. Chapter 4 lists the information needed to generate source terms that an applicant is required to submit with the application.

\subsection{DEFINITIONS}

The following definitions apply to terms used in this report:

Activation Gases: The gases (including oxygen, nitrogen, and argon) that become radioactive as a result of irradiation in the core.

Anticipated Operational 0ccurrences: Unplanned releases of radioactive materials from miscellaneous actions such as equipment failure, operator error, administrative error, that are not of consequence to be considered an accident.

Chemical Waste Steam: Normally liquids that contain relatively high concentrations of decontaminants, regenerants, or chemical compounds other than detergents. These liquids originate primarily from resin regenerant and laboratory wastes.

Clean Waste System: Normally tritiated, nonaerated, low-conductivity liquids consisting primarily of liquid waste collected from equipment leaks and drains and certain valve and pump seal leakoffs. These liquids originate from systems containing primary coolant and are normally reused as primary coolant makeup water. 
Decontamination Factor (DF): The ratio of the initial amount of a nuclide in a stream (specified in terms of concentration or activity of radioactive materials) to the final amount of that nuclide in a stream following treatment by a given process.

Detergent Waste Stream: Liquids that contain detergent, soaps, or similar organic materials. These liquids consist principally of laundry, personnel shower, and equipment decontamination wastes that normally have a low radioactivity content.

Dirty Waste Stream (Floor Drains): Normally nontritiated, aerated, high-conductivity, non-primary-coolant quality liquids collected from building sumps and floor and sample station drains. These liquids are not readily amenable for reuse as primary coolant makeup water.

Effective Full Power Days: The number of days a plant would have to operate $100 \%$ licensed power to produce the integrated thermal power output during a calendar year, i.e.,

$$
\text { Effective Ful1 Power Days }=\frac{\text { Integrated Thermal Power }}{\text { Licensed Power Level }}=\frac{{ }_{i} P_{i} T_{i}}{P_{\text {total }}}
$$

where

$$
\begin{array}{ll}
P_{i} & \text { is the } i \text { th power level, in MWt; } \\
P_{\text {total }} & \text { is the licensed power level, in MWt; and } \\
T_{i} & \text { is the time of operation at power level } P_{i} \text {, in days. }
\end{array}
$$

Fission Product: A nuclide produced either by fission or by subsequent radioactive decay or neutron activation of the nuclides formed in the fission process.

Gaseous Effluent Stream: Processed gaseous wastes containing radioactive materials resulting from the operation of a nuclear power reactor.

Liquid Effluent Stream: Processed liquid wastes containing radioactive materials resulting from the operation of a nuclear power reactor.

Partition Coefficient (PC): The ratio of the concentration of a nuclide in the gas phase to the concentration of a nuclide in the liquid phase when the liquid and gas are at equilibrium.

Partition Factor (PF): The ratio of the quantity of a nuclide in the gas phase to the total quantity in both the liquid and gas phases when the liquid and gas are at equilibrium. 
Plant Capacity Factor: The ratio of the average net power to the rated power capacity.

Primary Coolant: The fluid circulated through the reactor to remove heat. The primary coolant activity is considered to be constant over a range of power levels, coolant and cleanup flows, and coolant volumes. Radionuclide concentrations given in this NUREG are based on a recent compilation of available operating data. Therefore, the concentration values in NUREG-0017, Rev. I differ from the ANSI N237 values (Ref. 1). Provisions are made in the PWR-GALE Code, in accordance with the recommendations of the standard, for adjusting coolant concentrations should the plant be designed to parameters that are outside the ranges considered in the standard. The radionuclide concentrations used are considered to be representative of measured values based on the available operating data. The radionuclides are divided into the following categories:

1. Noble gases

2. Halogens $(\mathrm{Br}, \mathrm{I})$

3. $\mathrm{Cs}, \mathrm{Rb}$

4. Water activation products

5. Tritium

6. Other nuclides (as 1isted in Tables 2-2 and 2-3 of Chapter 2 of this document)

Radioactive Halogens: The isotopes of fluorine, chlorine, bromine, and iodine. The radicactive isotopes of iodine are the key isotopes considered in dose calculations.

Radioactive Noble Gases: The radioactive isotopes of helium, neon, argon, krypton, xenon, and radon, which are characterized by their chemical inactivity. The radioactive isotopes of krypton and xenon are the key elements considered in dose calculations.

Radioactive Release Rate: The average quantity of radioactive material released to the environment from a nuclear power reactor during normal operation, including anticipated operational occurrences.

Secondary Coolant: The coolant converted to steam by the primary coolant in a heat exchanger (steam generator) to power the turbine. The radionuclide concentrations in the secondary coolant are obtained as discussed above in the definition of primary coolant. 
Source Term: The calculated average quantity of radioactive material released to the environment from a nuclear power reactor during norma 1 operation, including anticipated operational occurrences. The source term is the isotopic distribution of radioactive materials used in evaluating the impact of radioactive releases on the environment.

Steam Generator Blowdown: Liquid removed from a steam generator in order to maintain proper water chemistry.

Tramp Uranium: The uranium present on the cladding of a fuel rod.

Turbine Building Floor Drains: Liquids of high conductivity and lowlevel radioactivity primarily resulting from secondary system leakage, steam trap drains, sampling system drainage, and maintenance and waste drains.

\subsection{GASEOUS SOURCE TERMS}

The following sources are considered in calculating the releases of radioactive materials (noble gases, radioactive particulates, carbon-14, tritium, argon-41, and iodine) in gaseous effluents from normal operation, including anticipated operational occurrences:

1. Waste gas processing system;

2. Steam generator blowdown system;

3. Condenser air ejector exhaust;

4. Containment purge exhaust;

5. Ventilation exhaust air from the auxiliary, and turbine buildings, and the spent fuel pool area; and

6. Steam leakage from the secondary system.

The releases of radioactive materials in gaseous effluents from the following sources are calculated to be less than $1 \mathrm{Ci} / \mathrm{yr}$ of noble gases and $10^{-4} \mathrm{Ci} / \mathrm{yr}$ of iodine-131. Therefore, the following releases are considered negligible:

1. Steam releases due to steam dumps to the atmosphere and lowpower physics testing and

2. Ventilation air from buildings not covered in 5. above.

The calculational model considers inputs to the waste gas processing system from both continuous stripping of the primary coolant during normal operation and from degassing the primary coolant for two cold shutdowns per year. For plants equipped with steam generator blowdown systems, the model considers iodine present in gases leaving the system 
vent. The PWR-GALE Code calculates the release rates of noble gases and iodine to building atmospheres based on coolant leakage rates to buildings. Radioiodine releases are related to the iodine-131 coolant concentrations for the PWR being evaluated. Particulate release rates are based on measurements at operating PWR's.

Chapter 2 provides iodine and particulate decontamination factors for removal equipment and parameters for calculating holdup times for noble gases and for calculating tritium, argon-4l and carbon-14 releases.

\subsection{LIQUID SOURCE TERMS}

The following sources are considered in calculating the release of radioactive materials in liquid effluents from normal operation, including anticipated operational occurrences:

1. Processed water generated from the boron recovery system to maintain plant water balance or for tritium control;

2. Processed liquid waste discharged from the dirty waste or miscellaneous waste systems;

3. Processed 1iquid waste discharged from the steam generator blowdown treatment system;

4. Processed liquid waste discharged from the chemical waste and condensate demineralizer regeneration system;

5. Liquid waste discharged from the turbine building floor drain sumps; and

6. Detergent waste.

The radioactivity input to the liquid radwaste treatment system is based on the flow rates of the liquid waste streams and their radioactivity levels expressed as a fraction of the primary coolant activity (PCA). The PCA is based on the recommendations of the American National Standard (ANSI N237) Source Term Specification (Ref. 1), with the changes as noted in Section 1.2 under the Primary Coolant definition.

Radionuclide removal by the liquid radwaste treatment system is based on the following parameters:

1. Decay during collection and processing and

2. Removal by the proposed treatment systems, e.g., filtration, ion exchange, evaporation, reverse osmosis, and plateout.

For PWR's using a deep-bed condensate demineralizer, the inventory of radionuclides collected on the demineralizer resins is calculated by considering the flow rate of condensate at main steam activity that 
is processed through the demineralizers and radionuclide removal using the decontamination factors given in Chapter 2. The activity on the condensate demineralizer resins will also include the steam generator blowdown activity if the blowdown is recycled to the condensate demineralizers. The radioactivity content of the demineralizer regenerant solution is obtained by considering that all the radioactivity is removed from the resins at the interval dictated by the regeneration frequency.

Methods for calculating collection and processing times and the decontamination factors for radwaste treatment equipment are given in this chapter. The liquid radioactive source terms are adjusted to compensate for equipment downtime and anticipated operational occurrences.

For plants using an onsite laundry, a standard detergent waste source term, adjusted for the treatment provided, is added to the adjusted source term.

\subsection{INSTRUCTIONS FOR COMPLETING PWR-GALE CODE INPUT DATA CARDS}

\subsubsection{PARAMETERS INCLUDED IN THE PWR-GALE CODE}

The parameters listed below are built into the PWR-GALE Code since they are generally applicable to all PWR source term calculations and do not require entry on input data cards.

\subsubsection{The P1ant Capacity Factor}

0.80 (292 effective full power days per year).

\subsubsection{Radionuclide Concentrations in the Primary Coolant, Secondary} Coolant, and Main Steam

See Section 2.2.3 of Chapter 2 of this document.

\subsubsection{Radioiodine Releases from Building Ventilation Systems Prior to Treatment}

See Table 1-1. For a discussion of the normalization techniques see Section 2.2.4.

\subsubsection{Radioactive Particulate Releases from Building Ventilation} Systems Prior to Treatment

See Table 1-2.

\subsubsection{Noble Gas Releases from Building Ventilation Systems}

Noble Gas Releases from the containment building are based on a leakage rate of $3 \%$ /day of primary coolant noble gas inventory. Releases from the auxiliary building are based on $160 \mathrm{lb} /$ day primary coolant leakage. Releases from the turbine building are based on $1700 \mathrm{lb} / \mathrm{hr}$ steam leakage. 
TABLE $1-1^{\dagger *}$

RADIOIODINE RELEASES FROM BUILDING VENTILATION

SYSTEMS PRIOR TO TREATMENT

$(\mathrm{Ci} / \mathrm{yr} / \mu \mathrm{Ci} / \mathrm{g})$

Containment

Building

Auxiliary

Building**
Turbine

Building ***

Annual Normalized* Iodine

Release Rate
Power Operation
$8.0 \times 10^{-4 t t}$
$0.72^{\dagger}$
$3.8 \times 10^{3}$
Refueling/Maintenance
$0.32 * \star$
2.59
$4.2 \times 10^{2}$ Outages

$t^{\star}$ The values in this table come from Tables 2-13 through 2-16.

* The normalized release rate, during different modes of operation, represents the effective leak rate for radioiodine. It is the combination of the reactor water leakage rate into the building and the partitioning of the radioiodine between the water phase in the leakage and the gas phase where it is measured. For the turbine building the effective leak rate must consider the carryover for radioiodine from water to steam in the steam generator.

** To obtain the actual iodine release from these buildings in Ci/yr, multiply the normalized release by the iodine coolant concentration in $\mu \mathrm{Ci} / \mathrm{g}$.

$\star \star \star$ To obtain the actual iodine release from the turbine building in $\mathrm{Ci} / \mathrm{yr}$, multiply the normalized release by the secondary coolant concentration in $\mu \mathrm{Ci} / \mathrm{g}$ and by the partition coefficient (NS) from Table 2-6.

$+\quad$ Includes contribution from the fuel pool area.

t† This release rate is expressed in \%/day of leakage of primary coolant inventory of iodine and represents the effective leak rate for radioiodine. It is the combination of the reactor water leakage rate into the buildings, and the partitioning of the radioiodine between the water phase in the leakage and the gas phase where it is measured. In order to obtain the releases in curies/year during power operations from the containment building of a particular PWR, the normalized leak rates in Table 1-1, are multiplied in the PWR-GALE Code by the iodine concentration in the reactor coolant for that particular PWR, and then this leak rate is considered along with the containment purging method for that particular PWR. 
TABLE $1-2$

RADIOACTIVE PARTICULATE RELEASES FROM BUILDING VENTILATION SYSTEMS $\frac{\text { PRIOR TO TREATMENT* }}{(\mathrm{C} i / \mathrm{yr}) / \text { Unit }}$

\begin{tabular}{|c|c|c|c|c|}
\hline Nuclide & Containment & $\begin{array}{l}\text { Auxiliary } \\
\text { Building } \\
\end{array}$ & $\begin{array}{c}\text { Fuel Pool } \\
\text { Area } \\
\end{array}$ & $\begin{array}{c}\text { Waste Gas } \\
\text { System }\end{array}$ \\
\hline$C r-51$ & $9.2(-3)^{\dagger}$ & $3.2(-4)$ & $1.8(-4)$ & $1.4(-5)$ \\
\hline$M n-54$ & $5.3(-3)$ & $7.8(-5)$ & $3.0(-4)$ & $2.1(-6)$ \\
\hline $\mathrm{Co-57}$ & $8.2(-4)$ & NA & NA & NA \\
\hline Co-58 & $2.5(-2)$ & $1.9(-3)$ & $2.1(-2)$ & $8.7(-6)$ \\
\hline Co-60 & $2.6(-3)$ & $5.1(-4)$ & $8.2(-3)$ & $1.4(-5)$ \\
\hline $\mathrm{Fe}-59$ & $2.7(-3)$ & $5.0(-5)$ & NA & $1.8(-6)$ \\
\hline$S r-89$ & $1.3(-2)$ & $7.5(-4)$ & $2.1(-3)$ & $4.4(-5)$ \\
\hline$S r-90$ & $5.2(-3)$ & $2.9(-4)$ & $8.0(-4)$ & $1.7(-5)$ \\
\hline$Z r-95$ & NA & $1.0(-3)$ & $3.6(-6)$ & $4.8(-6)$ \\
\hline$N b-95$ & $1.8(-3)$ & $3.0(-5)$ & $2.4(-3)$ & $3.7(-6)$ \\
\hline$R u-103$ & $1.6(-3)$ & $2.3(-5)$ & $3.8(-5)$ & $3.2(-6)$ \\
\hline$R u-106$ & NA & $6.0(-6)$ & $6.9(-5)$ & $2.7(-6)$ \\
\hline$S b-125$ & NA & $3.9(-6)$ & $5.7(-5)$ & NA \\
\hline Cs -134 & $2.5(-3)$ & $5.4(-4)$ & $1.7(-3)$ & $3.3(-5)$ \\
\hline Cs-136 & $3.2(-3)$ & $4.8(-5)$ & NA & $5.3(-6)$ \\
\hline Cs -137 & $5.5(-3)$ & $7.2(-4)$ & $2.7(-3)$ & $7.7(-5)$ \\
\hline $\mathrm{Ba}-140$ & $N A$ & $4.0(-4)$ & NA & $2.3(-5)$ \\
\hline $\mathrm{Ce}-141$ & $1.3(-3)$ & $2.6(-5)$ & $4.4(-7)$ & $2.2(-6)$ \\
\hline
\end{tabular}

NA - No release observed from this source. Release assumed to be less than $1.0 \%$ of total.

$+\quad 9.2(-3)=9.2 \times 10^{-3}$.

* The values in this table come from Tables 2-17 through 2-21. 


\subsubsection{Containment Building Purge Frequency}

Two purges at cold shutdown per year plus a continuous purge specified by the applicant in his containment design.

\subsubsection{Primary System Volumes Degassed per Year}

Two coolant volumes per year for cold shutdowns plus volumes degassed due to continuous stripping.

\begin{tabular}{cc}
1.5 .1 .8 & \multicolumn{2}{c}{ Steam Generator Partition Coefficient } & $(P C)$ \\
$\frac{\text { Once-through }}{\text { Iodine }}$ & $P C$ \\
Nonvolatiles & 1.0 \\
Recirculation U-Tube & 1.0 \\
Iodine & \\
Nonvolatiles & 0.01 \\
& 0.005
\end{tabular}

1.5.1.9 Radioiodine Releases from the Main Condenser Air Ejector Exhaust Prior to Treatment

The normalized release rate of radioiodine from the main condenser air ejector exhaust prior to treatment is $1.7 \times 10^{3} \mathrm{Ci} / \mathrm{yr} / \mu \mathrm{Ci} / \mathrm{g}$. The normalized release rate represents the effective release rate for radioiodine. It is the combination of the steam flow to the main condenser, the partitioning of radioiodine between the main condenser and the air ejector exhaust where it is measured, and the partition coefficient for radioiodine from water to steam in the steam generator. To obtain the actual iodine release from the main condenser air ejector exhaust in Ci/yr, multiply the normalized release by the secondary coolant concentration in $\mu \mathrm{Ci} / \mathrm{g}$ and by the iodine partition coefficient (NS) from Table 2-6.

\subsubsection{Containment Internal Cleanup System}

For systems using an internal cleanup system, the PWR-GALE Code calculates the iodine concentration in the containment atmosphere based on 16 hours of system operation prior to purging, an iodine removal efficiency for the charcoal adsorbers corresponding to Table 1-5, a particulate DF of 100 for HEPA filters and an internal mixing efficiency of $70 \%$.

\subsubsection{Detergent Wastes}

The radionuclides listed in Table 2-27 of Chapter 2 are assumed to be released unless treatment is provided or laundry is not processed on site. 


\subsubsection{Tritium Releases}

The tritium releases through the combined liquid and vapor pathways are $0.4 \mathrm{Ci} / \mathrm{yr}$ per MWt. The quantity of tritium released through the liquid pathway is based on the calculated volume of liquid released, excluding secondary system wastes, with a primary coolant tritium concentration of $1.0 \mu \mathrm{Ci} / \mathrm{ml}$ up to a maximum of 0.9 of the total quantity of tritium calculated to be available for release. It is assumed that the remainder of the tritium produced is released as a gas from building ventilation exhaust systems.

\subsubsection{Argon-41 Re leases}

The annual quantity of argon-41 released from a pressurized water reactor is $34 \mathrm{Ci} / \mathrm{yr}$. The argon- 41 is released to the environment via the containment vent when the containment is vented or purged.

\subsubsection{Carbon-14 Releases}

The annual quantity of carbon-14 released is $7.3 \mathrm{Ci} / \mathrm{yr}$, of which the releases from the containment, auxiliary building and waste gas system are $1.6,4.5$ and $1.2 \mathrm{Ci} / \mathrm{yr}$, respectively.

1.5.1.15 Decontamination Factors for Condensate Demineralizer

\begin{tabular}{|c|c|c|c|}
\hline Demineralizer & Anion & $\mathrm{Cs}, \mathrm{Rb}$ & Other Nuclides \\
\hline Deep Bed & 10 & 2 & 10 \\
\hline Powdex & 10 & 2 & 10 \\
\hline
\end{tabular}

Note: For a system using filter/demineralizers (Powdex), a zero is entered for a regeneration frequency as explained later in Section 1.5.2.10.

1.5.1.16 Primary Coolant Purification System Demineralizers

\begin{tabular}{|c|c|c|c|}
\hline Demineralizer & Anion & $\mathrm{Cs}, \mathrm{Rb}$ & Other Nuclides \\
\hline Mixed Bed & 100 & 2 & 50 \\
\hline Cation & 1 & 10 & 10 \\
\hline
\end{tabular}

1.5.1.17 Releases of Radioactive Material in Liquid Waste from the Turbine Building Floor Drain System

$7200 \mathrm{gal} /$ day at main steam activity.

\subsubsection{Regeneration of Condensate Demineralizers}

Flow rates and concentrations of radioactive materials routed to the liquid radwaste treatment system from the chemical regeneration of the condensate demineralizers are based on the following parameters: 
1. Liquid flow to the demineralizer is based on the radioactivity of the main steam and the fraction of radioactivity which does not bypass the condensate demineralizer if there is pumped forward flow. The steam generator blowdown radioactivity is added to the condensate radioactivity if the blowdown is processed through the condensate demineralizer.

2. All radionuclides removed from the secondary coolant by the demineralizer resins are removed from the resins during chemical regeneration. The radioactivity in the regenerant wastes is adjusted for radionuclide decay during demineralizer operation.

\subsubsection{Adjustment to Liquid Radwaste Source Terms for Anticipated} Operational Occurrences

1. The calculated source term is increased by $0.16 \mathrm{Ci} / \mathrm{yr}$ per reactor using the same isotopic distribution as for the calculated source term to account for anticipated occurrences such as operator errors resulting in unplanned releases.

2. Evaporators are assumed to be unavailable for two consecutive days per week for maintenance. If a two-day holdup capacity or an alternate evaporator is available, no adjustment is needed. If less than a two-day capacity is available, the waste excess is assumed to be handled as follows:

a. Clean or Dirty Waste - Processed through an alternative system (if available) using a discharge fraction consistent with the lower purity system.

b. Chemical Waste - Discharged to the environment to the extent holdup capacity or an alternative evaporator is not available.

\subsubsection{PARAMETERS REQUIRED FOR THE PWR-GALE CODE}

Complete the cards designated in the sections below by "(SAR/ER)" from information given in the Safety Analys is and Environmental Reports. Complete the remaining cards (i.e., those not designated below as "(SAR/ER)" cards), using the principal source term parameters specified below and discussed in Chapter 2 of this document.

\subsubsection{Card 1: Name of Reactor (SAR/ER)}

Enter in spaces 33-60 the name of the reactor.

Enter in spaces $78-80$ the type of reactor, i.e., PWR.

\subsubsection{Card 2: Thermal Power Level (SAR/ER)}

Enter in spaces 73-80 the maximum thermal power level (in MWt) evaluated for safety considerations in the Safety Analys is Report. 


\subsubsection{Card 3: Mass of Coolant in Primary System (SAR/ER)}

Enter in spaces $73-80$ the mass of coolant (in $10^{3}$ ib) in the primary system at operating temperature and pressure.

1.5.2.4 Card 4: Primary System Letdown Rate (SAR/ER)

Enter in spaces $73-80$ the average letdown rate (gal/min) from the primary system to the purification demineralizers.

1.5.2.5 Card 5: Letdown Cation Demineralizer Flow Rate (SAR/ER)

Enter in spaces $73-80$ the annual average flow rate (gal/min) through the cation demineralizers for the control of cesium in the primary coolant. The average flow rate is determined by multiplying the average letdown rate (value entered on Card 4 ) by the fraction of time the cation demineralizers are in service to obtain the average cation demineralizer flow rate.

1.5.2.6 Card 6: Number of Steam Generators (SAR/ER)

Enter in spaces $73-80$ the number of steam generators.

\subsubsection{Card 7: Total Steam Flow (SAR/ER)}

Enter in spaces $73-80$ the total steam flow (in $10^{6} 1 \mathrm{~b} / \mathrm{hr}$ ) for all steam generators.

\subsubsection{Card 8: Mass of Liquid in Each Steam Generator (SAR/ER)}

Enter in spaces $73-80$ the mass of liquid (in $10^{3}$ lb) in each steam generator.

\subsubsection{Card 9: Steam Generator Blowdown Rate and Blowdown Treatment Method (SAR/ER)}

Enter in spaces 37-44 the steam generator blowdown rate as given in the applicants SAR or ER.

Enter total blowdown rate in thousands of $1 \mathrm{~b} / \mathrm{hr}$ in spaces 37-44. For a once-through steam generator, leave spaces 37-44 blank.

Describe the Blowdown Treatment Method as follows:

1. Enter 0 in space 80 if the blowdown is recycled to the condensate system after treatment in the blowdown system whether or not there are condensate demineralizers.

2. Enter 1 in space 80 if the steam generator blowdown is recycled directly to condensate system demineralizers without prior treatment in the blowdown system. 
3. Enter 2 in space 80 if the steam generator blowdown is not recycled to the condensate system.

If the plant has once-through steam generators, leave space 80 blank. 1.5.2.10 Card 10: Condensate Demineralizer Regeneration Time

For deep-bed condensate demineralizers which do not use ultrasonic resin cleaner, use a 1.2-day regeneration frequency. Multiply the frequency by the number of demineralizers and enter the calculated number of days in spaces 73-80; for deep-bed condensate demineralizers which use ultrasonic resin cleaning, use an 8-day regeneration frequency. For filter/demineralizers (Powdex) or if condensate demineralizers are not used, enter zeros in spaces 73-80.

\subsubsection{Card 11: Fraction of Feedwater Through Condensate Demineralizer (SAR/ER)}

Enter in spaces 73-80 the fraction of feedwater to the steam generator processed through the condensate demineralizers. If condensate demineralizers are not used, enter 0.0 in spaces $73-80$.

\subsubsection{Cards 12-29: Liquid Radwaste Treatment System Input Parameters}

Six 1 iquid radwaste inlet streams are considered in the PWR-GALE Code:

1. Shim Bleed, Cards 12-14.

2. Equipment Drain Waste, Cards 15-17.

3. Clean Waste, Cards 18-20.

4. Dirty Waste, Cards 21-23.

5. Blowdown Waste, Cards 24-26.

6. Regenerant Wastes, Cards 27-29.

Three input data cards are used to define the major parameters for each of the six waste streams. Essentially the same information is needed on the three input data cards used for each of the six waste streams. The instructions given in this section are applicable to all six waste streams with the following exception: The inlet waste activity is not entered for Cards 12, 24, and 27 for the shim bleed, blowdown wastes, or regenerant wastes since that activity for these wastes is calculated by the PWR-GALE Code.

Cards 12-14 are used only for the shim bleed stream. For reactor designs that combine the shim bleed with other reactor grade wastes prior to processing, the other wastes are entered as equipment drain wastes on Cards 15-17. 
The entries required on the first card $(12,15,18,21,24$, and 27) for each of the six waste streams, respectively, considered in the PWR-GALE Code are outlined below and described in more detail in Section 1.5.2.15.1.

1. Enter in spaces 17-39 the name of the waste stream (Card 24 spaces 17-44).

2. Enter in spaces $42-49$ the flow rate (in gal/day) of the inlet stream (except on Cards 24 and 27).

3. Enter in spaces 57-61 the activity of the inlet stream expressed as a fraction of primary coolant activity (PCA) (except on Cards 12, 24 and 27).

The second card $(13,16,19,22,25$, and 28) for each waste stream contains the overall system decontamination factors for the three categories of radionuclides, as follows:

1. Enter in spaces 21-28 the DF for jodine.

2. Enter in spaces 34-41 the DF for cesium and rubidium.

3. Enter in spaces 47-54 the DF for other nuclides.

The following entries are required on the third card $(14,17,20$, 23, 26, and 29) for each waste stream:

1. Enter in spaces 28-33 waste collection time (in days) prior to processing.

2. Enter in spaces 48-53 waste processing and discharge times (in days).

3. Enter in spaces $72-77$ the average fraction of wastes to be discharged after processing.

Cards 24-26 are for waste inputs due to steam generator blowdown.

1. Card 24

a. For recirculating U-tube steam generator systems, enter the fraction of the blowdown stream processed in spaces 73-80. The PWR-GALE Code will calculate releases based on steam generator blowdown wastes.

b. For once-through steam generator systems, leave spaces 73-80 blank.

2. Card 25

a. If the steam generator blowdown is not recycled to the condensate system, enter blowdown system DF's as explained for Card 13. 
b. If the steam generator blowdown is recycled directly to the condensate system demineralizers without prior treatment in the blowdown system, enter DF of 1.0 for iodine in spaces 21-28, DF of 1.0 for cesium and rubidium in spaces 34-41, and DF of 1.0 for other nuclides in spaces 47-54.

c. If the steam generator blowdown is recycled to the condensate system demineralizers after treatment in the blowdown system, enter blowdown system DF's as explained for Card 13.

\section{Card 26}

Complete Card 26 as explained for Card 14.

Cards 27-29 are for waste inputs due to regenerant wastes.

1. $\quad$ Card 27

a. For recirculating U-tube steam generator systems that do not utilize condensate demineralizers in the secondary system, leave spaces $73-80$ blank.

b. For once-through steam generator systems and for recirculating U-tube steam generator systems that utilize condensate demineralizers in the secondary system, enter the regeneration solution waste flow (gal/day) in spaces 73-80. The inlet waste activity is not needed since the activity is calculated by the PWR-GALE Code.

2. Cards 28 and 29

Complete Cards 28 and 29 as explained for Cards 13 and 14.

The following sections explain in more detail the use of the parameters in this report and the information given in the SAR/ER to make the data entries on Cards 12-92 listed above.

\subsection{Liquid Waste Flow Rates and Activities (Cards 12, 15, 18, 21 ,} 24 and 27)

Flow rates and activity are calculated, using the waste volumes and activities given in Table 1-3. To the input flow rates given in the table, add expected flows and activities more specific to the plant design as given in the SAR/ER. With the exception of the shim bleed, the individual streams are combined based on the radwaste treatment system described in the SAR/ER.

Waste streams processed with the shim bleed are entered as equipment drain wastes on Cards 15-17. Input activities are based on the weighted average activity of the composite stream entering the waste collection 
TABLE $1-3$

PWR LIQUID WASTES

EXPECTED DAILY AVERAGE INPUT FLOW RATE (in Gal/day)

Type of treatment of blowdown recycled to secondary system (U-tube steam generator plants) or type of

treatment of condensate (once-through steam generator plants)

SOURCE

\begin{tabular}{lcc} 
& generator plants) \\
\hline $\begin{array}{l}\text { Deep-bed cond. } \\
\text { demineralizers }\end{array}$ & $\begin{array}{c}\text { Deep-bed cond. } \\
\text { demineralizers } \\
\text { with ithout }\end{array}$ \\
$\begin{array}{l}\text { resincleaner } \\
\text { ultrasonic }\end{array}$ & Filter- \\
\end{tabular}

Plant with

blowdown treat ment. Product not recycled to condenser or secondary coolant

system

FRACTION OF PRIMARY COOLANT ACTIVITY (PCA)

1. REACTOR CONTAINMENT

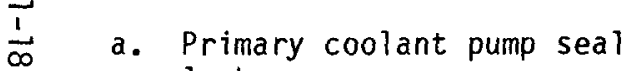

20 leakage

b. Primary coolant leakage, miscellaneous sources

c. Primary coolant equipment drains

2. PRIMARY COOLANT SYSTEMS

(OUTSIDE OF CONTAINMENT)

a. Primary coolant system equipment drains

b. Spent fuel pit liner drains

c. Primary coolant sampling system drains

d. Auxiliary building floor drains
80

80

80

1.0

700

700

200

200

200

0.05

0.1
80

20

10

10

500

700

200

200
20

10

500

0.1

$1.67 \star$

0.001 
TABLE 1-3 (Continued)

3. SECONDARY COOLANT SYSTEMS

a. Secondary coolant sampling system drains

b. Condensate demineralizer rinse and transfer

solutions

c. Condensate demineralizer regenerant solutions

d. Ultrasonic resin cleaner solutions

e. Condensate filterdemineralizer backwash

f. Steam generator blowdown

$\overrightarrow{\vec{b}}$ g. $\begin{aligned} & \text { Turbine building floor } \\ & \text { drains }\end{aligned}$

$\begin{array}{rrr}1400 & 1400 & 1400 \\ 3000 & 12000 & - \\ 850 & 3400 & - \\ 15000 & - & - \\ - & - & 8100 \\ - & - & - \\ 7200 & 7200 & 7200\end{array}$

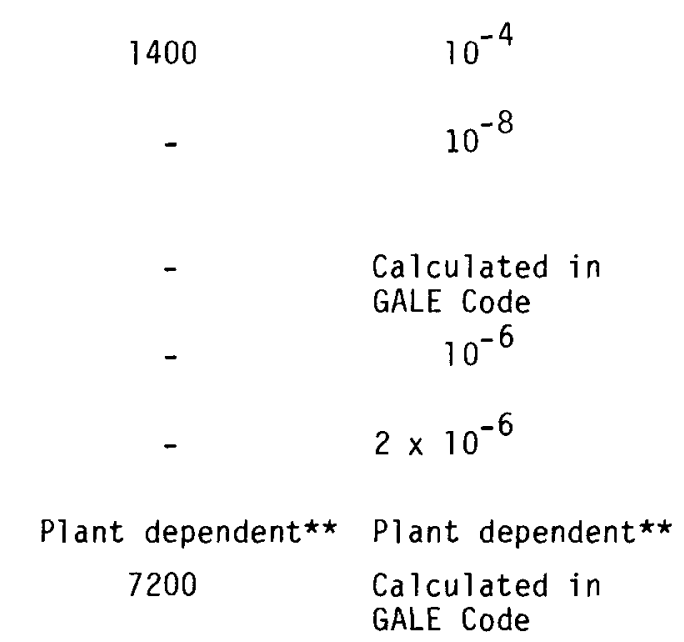

4. DETERGENT AND DECONTAMINATION SYSTEMS

a. On-site laundry facility

b. Hot showers

c. Hand wash sink drains

d. Equipment and area

decontamination

\begin{tabular}{|c|c|c|c|c|}
\hline 300 & 300 & 300 & 300 & See Table 2-26 \\
\hline legligible & Negligible & Negligible & Negligible & - \\
\hline 200 & 200 & 200 & 200 & See Table $2-26$ \\
\hline 40 & 40 & 40 & 40 & See Table 2-26 \\
\hline
\end{tabular}

TOTALS

$29,700 \quad 26,300$

19,000

10,000

* About 40 percent of the leakage flashes, resulting in PCA fraction of the leakage greater than 1.0 .

** Input parameter. 
tanks. For example, if the inlet streams $A, B$, and $C$ enter the dirty waste collector tank at average rates and PCA as 1 isted below,

$$
\begin{array}{lr}
\text { Stream A } & 1,000 \mathrm{gal} / \text { day at } 0.01 \mathrm{PCA} \\
\text { Stream B } & 2,000 \mathrm{gal} / \mathrm{day} \text { at } 0.1 \mathrm{PCA} \\
\text { Stream C } & 500 \mathrm{gal} / \text { day at } 1.0 \mathrm{PCA}
\end{array}
$$

the composite A, B, C activity would be calculated as follows:

$$
\frac{(1,000 \mathrm{gal} / \mathrm{day})(0.01 \mathrm{PCA})+(2,000 \mathrm{gal} / \mathrm{day})(0.1 \mathrm{PCA})+(500 \mathrm{gal} / \mathrm{day})(1.0 \mathrm{PCA})}{(1,000 \mathrm{ga} 1 / \mathrm{day}+2,000 \mathrm{gal} / \mathrm{day}+500 \mathrm{gal} / \mathrm{day})}=0.2 \mathrm{PCA}
$$

The entries on Card 21 for this example would then be: spaces 17-33, "Dirty Waste"; spaces $42-49,3500$. ; spaces $57-61$, "0.2".

The input flow rates and activities are entered in units of gal/day and fractions of PCA, respectively.

1.5.2.12.2 Decontamination Factors for Equipment Used in the Liquid

Radwaste Treatment System (Cards 13, 16, 19,22, 25, and 28)

The decontamination factors (DF's) given in this document are used in the PWR-GALE Code. The DF's represent the expected equipment performance averaged over the life of the plant, including downtime. The following factors should be considered in calculating the overall decontamination factors for the various systems:

1. DF's are categorized by one of the following types of radionuclides:

$$
\begin{aligned}
& \text { a. Halogens } \\
& \text { b. Cs, Rb } \\
& \text { c. Other Nuclides }
\end{aligned}
$$

Note: A DF of 1 is assumed by the PWR-GALE Code for tritium. Noble gases and water activation products, e.g., N-16, are not considered in the liquid code.

2. The system DF for each inlet stream is the product of the individual equipment DF's in each of the subsystems.

3. Equipment that is used optionally (as required) and not included in the normal flow scheme should not be considered in calculating the overall system DF.

Table 1-4 shows the decontamination factors to be used for PWR systems. 
TABLE $1-4$

DECONTAMINATION FACTORS FOR PWR LIQUID WASTE TREATMENT SYSTEMS

TREATMENT SYSTEM

Demineralizer

Mixed Bed

Primary coolant letdown (CVCS)

Radwaste $\left(\mathrm{H}^{+} \mathrm{OH}^{-}\right)$

Evaporator condensate polishing

Boron recycle

Steam generator blowdown

Cation bed (any system)

Anion bed (any system)

Powdex (any system)

Evaporators

Miscellaneous radwaste

Boric acid recovery
DECONTAMINATION FACTOR

Anion $\mathrm{Cs}, \mathrm{Rb} \quad$ Other Nuclides

100

2

50

$10^{2}(10) * \quad 2(10)$

$10^{2}(10)$

5

1

10

10

$10^{2}(10)$

2

10

$1(1)$

$10(10)$

$10^{2}(10)$

$10^{2}(10)$

$10(10)$

$10(10)$

$1(1)$

$1(1)$

10(10)

$2(10)$

$10(10)$
A1) Nuclides

Except Iodine

$10^{3}$

$10^{3}$
Iodine $10^{2}$ $10^{2}$
Reverse Osmosis

Laundry wastes

Other liquid wastes

Filters
All Nuclides

30

10

DF of 1 for all nuclides

* For demineralizers in series, the DF for the second demineralizer is given in parentheses. 
The following example illustrates the calculation of the decontamination factor for a dirty waste treatment system: Assume that dirty wastes are collected; processed through a filter, an evaporator, and a mixed-bed polishing demineralizer; and collected for sampling. If required to meet discharge criteria, the contents of the waste sample (test) tank are processed through a mixed-bed demineralizer for additional radionuclide removal. This example may be summarized graphically as:

Demineralizer 2

Dirty waste - Filter - Evaporator - Demineralizer 1 - Waste sample collector tank tank

Extracting from Table 1-4 gives the following values for the example:

\begin{tabular}{|c|c|c|c|c|c|}
\hline & Filter & Evaporator & $\begin{array}{c}\text { Demineralizer } \\
1 \\
\end{array}$ & $\begin{array}{c}\text { Demineralizer } \\
2 \\
\end{array}$ & Product \\
\hline Iodine & 1 & $10^{2}$ & 5 & 1 & $5 \times 10^{2}$ \\
\hline $\mathrm{Cs}, \mathrm{Rb}$ & 1 & $10^{3}$ & 1 & 1 & $10^{3}$ \\
\hline Other Nuclides & 1 & $10^{3}$ & 10 & 1 & $10^{4}$ \\
\hline
\end{tabular}

These values are obtained as follows:

- A DF of 1.0 is applied to all nuclides for the filter.

- A DF of $10^{2}$ for iodine and $10^{3}$ for $C S$, Rb, and other nuclides is applied for the radwaste evaporator.

- A DF of 5 is applied for iodine, a DF of 1 for $C s, R b$ and a DF of 10 for the evaporator condensate polishing demineralizer.

- A DF of 1 is applied to the second demineralizer since this demineralizer's used is optional, and it is not used for normal operations.

- The product of the DF's is obtained by multiplication of the first four columns for each nuclide.

Thus on Card 22, the following would be entered: in spaces $21-28$, "500.0"; in spaces 34-41, "1000.0"; and in spaces 47-54, "10000.0".

1.5.2.12.3 Collection Time for Liquid Wastes (Cards 14, 17, 20, 23, 26, and 29 -- Spaces 29-33)

Collection time prior to processing is based on the input flow calculated above. Where redundant tanks are provided, assume the collection tank to be filled to $80 \%$ design capacity. If only one tank is provided, 
assume the tank to be filled to $40 \%$ design capacity. For example, if flow from a 1,000-gal/day floor drain is collected in two 20,000-gallon tanks prior to processing, collection time would be calculated as follows:

$$
\text { Collection time }\left(T_{c}\right)=\frac{(0.8)(20,000 \mathrm{gal})}{(1,000 \mathrm{ga} 1 / \text { day })}=16 \text { days }
$$

Then, for example, "16.0" should be entered in spaces 29-33 on Card 23. 1.5.2.12.4 Processing and Discharge Time (Cards 14, 17, 20, 23, 26, and 29 -- Spaces 48-53)

Decay during processing and discharge of liquid wastes is shown graphically as follows:

$$
\text { Tank A }-\mathrm{B}_{b}-\stackrel{\mathrm{R}}{O}_{\mathrm{b}} \mathrm{T}-\mathrm{R}_{c}-\text { Discharge Canal }
$$

where
$A$ is the capacity of initial tank in flow scheme, in gal;
$B$ is the limiting process based on equipment flow capacity, dimensionless;
$C$ is the capacity of final tank in flow scheme prior to discharge, in gal;
$R_{b}$ is the equipment flow capacity of Process $B$, in gal/day;
$R_{C}$ is the flow capacity of Tank $C$ discharge pump, in gal/day; and
$R_{0}$ is the rate of flow of additional waste inputs to Tank $C$, in gal/day.

$T_{p}$, the process time credited for decay, is calculated as follows, in days:

$$
T_{p}=\frac{0.8 A}{R_{b}} \text { for redundant tanks, or } T_{p}=\frac{0.4 A}{R_{b}} \text { for a single tank }
$$

$T_{d}$, the discharge time (50\% credited for decay), is calculated as follows, in days:

$$
T_{d}=\frac{0.8 C}{R_{C}} \text { for redundant tanks, or } T_{d}=\frac{0.4 C}{R_{C}} \text { for a single tank. }
$$


After performing the above two calculations, calculate whether credit may be taken for decay during discharge by determining whether

$$
\begin{aligned}
& 0.8 C>T_{p}\left(R_{b}+R_{0}\right) \text { for redundant tanks, or } \\
& 0.4 C>T_{p}\left(R_{b}+R_{0}\right) \text { for a single tank. }
\end{aligned}
$$

If so, then

$$
\text { Decay }=T_{p}+0.5 T_{d}
$$

where "Decay" is the new processing and discharge time to be entered in spaces 48-53 of the third card for each input stream (Cards 14, 17, 20, 23,26 , and 29).

If, however, $0.8 \mathrm{C}$ (or $0.4 \mathrm{C}$, as appropriate) $\leq T_{p}\left(R_{b}+R_{0}\right), T_{p}$ is used for the holdup time during processing, since Tank $C$ may be discharged before Tank $A$ has been completely processed. In this case, the $T_{p}$ value should be entered in spaces $48-53$ of the third card.

For example, for the following input waste stream:

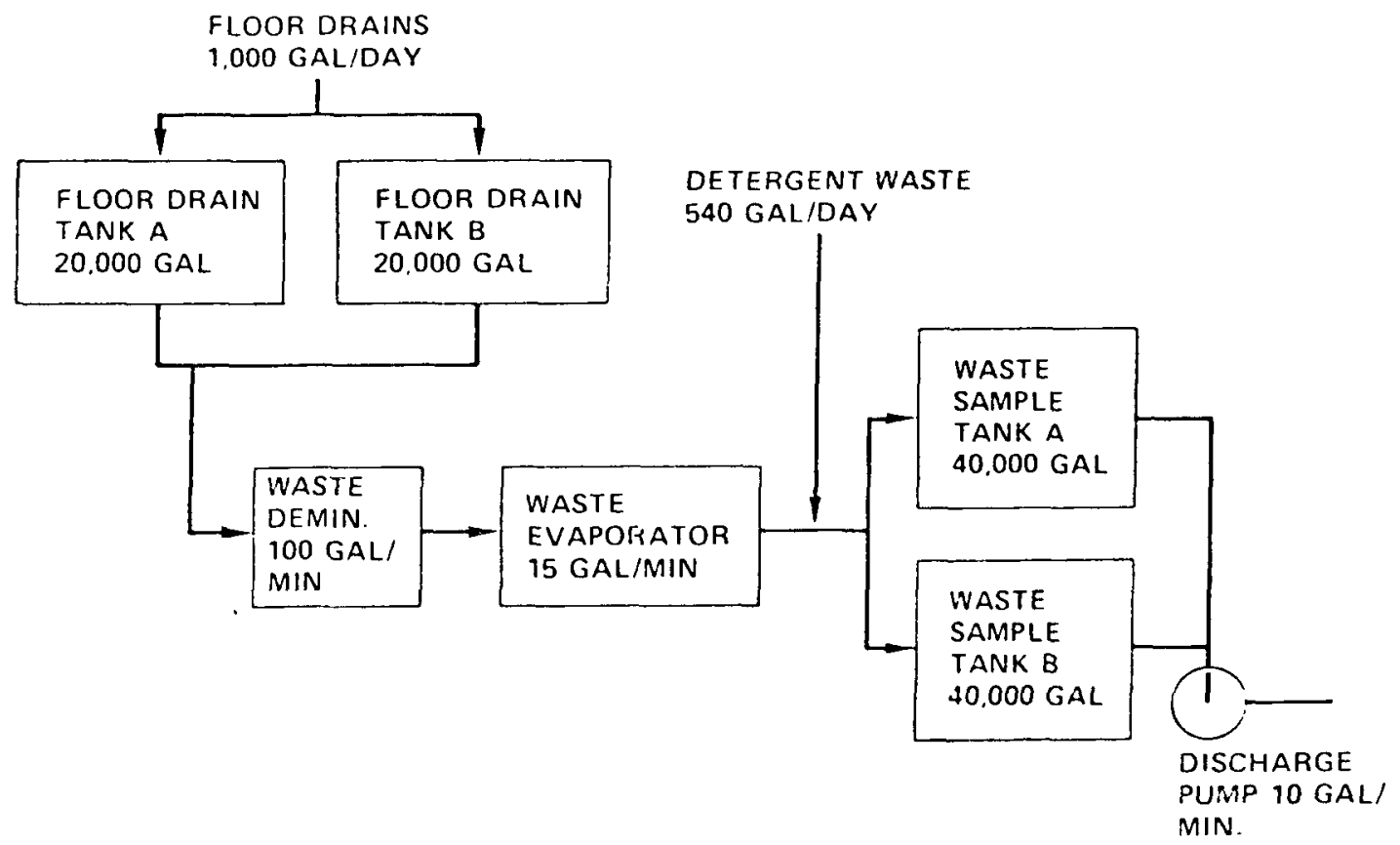


Decay time during processing and discharge is calculated as follows:

$$
\begin{aligned}
& \text { Process Time }\left(T_{p}\right)=\frac{(0.8)(20,000 \mathrm{gal})}{(15 \mathrm{gal} / \mathrm{min})(1440 \mathrm{~min} / \text { day })}=0.7 \text { day } \\
& \text { Discharge Time }\left(T_{d}\right)=\frac{(0.8)(40,000 \mathrm{gal})}{(10 \mathrm{gal} / \mathrm{min})(1440 \mathrm{~min} / \text { day })}=2.2 \text { days }
\end{aligned}
$$

Then, checking for decay credit, $0.8 \mathrm{C} /\left(\mathrm{R}_{\mathrm{b}}+\mathrm{R}_{0}\right)=1.45$ days, which is greater than $T_{p}$; therefore, credit is taken for $\left(T_{p}+0.5 T_{d}\right)$ or 1.8 days for processing and discharge. The input in spaces 48-53 to the Code is 1.8 days for processing and discharge time.

1.5.2.12.5 Fraction of Wastes Discharged (Cards 14, 17, 20, 23, 26, and 29 -- Spaces 72-77)

The percent of the wastes discharged after processing may vary between 10\% and 100\%, except as noted below, based on the capability of the system to process liquid waste during equipment downtime, waste volume surges, tritium control requirements, and tank surge capacity. A minimum value of $10 \%$ discharge for the liquid radioactive waste treatment system is used when the system is designed for maximum waste recycle, when the system capacity is sufficient to process wastes for reuse during equipment downtime and anticipated operational occurrences, and when a discharge route is provided. For steam generator blowdown treatment systems, less than 10\% discharge should be considered on a case-by-base basis, depending on system capacity.

The PWR-GALE Code calculates the release of radioactive materials in liquid waste from the following systems after processing. The quantity released is shown on the printout.

1. Boron Recovery System - Combined releases from both shim bleed

2. Miscellaneous Liquid Waste System - Combined releases from both clean and dirty waste subsystems.

3. Secondary Waste System - Releases from steam generator blowdown system, regenerant wastes from demineralizer regenerations, or both according to the plant design.

4. Turbine Building Floor Drain System - Releases of liquid from the turbine building floor drain system are calculated assuming no treatment prior to release. Straight decay time of 6 hours is built into the code.

5. Detergent Waste System - Combined releases from laundry operations, equipment decontamination solutions, and personnel decontamination showers. 


\subsubsection{Card 30: Letdown System}

1. Enter 0 in space 80 if there is not continuous gas stripping of the full letdown flow. (This sets $Y=0.0$. )

2. Enter 1 in space 80 if there is continuous degassification of the full letdown flow to the gaseous radwaste system via a gas stripper. (This sets $Y=1.0$. )

3. Enter 2 in space 80 if there is continuous purging of the volume control tank. (This sets $Y=0.25$.)

The total amount of fission gases routed to the gaseous radwaste system from several systems in the plant (e.g., volume control tank, shim bleed gas stripper, equipment drain tanks, cover gas) is calculated in the PWR-GALE Code. (For definition of "Y", see Tables 2-4 \& 2-5.)

\subsubsection{Cards 31-33: Holdup Time for Fission Gases Stripped from Primary Coolant}

The holdup time for gases stripped from the primary coolant is hand calculated because of the multiplicity of holdup system designs. The calculations are based on the following parameters:

1. Pressurized Storage Tanks

a. One storage tank is held in reserve for back-to-back shutdowns, one tank is in the process of filling, and the remainder are used for storage. The PWR-GALE Code will calculate the effective holdup time for filling and add it to the holdup time for storage.

b. Calculations are based on the waste gas input flow rate to the pressurized storage tanks, and a storage tank pressure $70 \%$ of the design value.

c. If the calculated holdup time exceeds 90 days, assume the remaining gases are released after 90 days.

The holdup time $\left(T_{h}\right)$ and fill time $\left(T_{f}\right)$ are calculated as follows:

$$
\begin{aligned}
& T_{f}=\frac{P V}{F} \\
& T_{h}=\frac{P V(n-2)}{F}
\end{aligned}
$$

where

$\mathrm{n}$ is the number of tanks; 
$n-2$ is the correction to subtract the tank being filled and the tank held in reserve;

$P \quad$ is the storage pressure, in atmospheres (dimensionless in this particular calculation);

$T_{f}$ is the time required to fill one tank, in days;

$T_{h}$ is the holdup time, in days;

$v \quad$ is the volume of each tank, in $\mathrm{ft}^{3}$ (STP); and

$F \quad$ is the waste gas flow rate to pressurized storage tanks. This flow rate should be supplied by the applicant for the specific type of waste gas system design. In the absence of specific data supplied by the applicant, we will use the data given in Section 2.2.12.1, in which the average value for the PWR's listed in Table 2-24 is $170 \mathrm{ft}^{3} /$ day (STP) per reactor for PWR's without recombiners; and for PWR's with recombiners, the average value for the PWR's listed in Table $2-25$ is $30 \mathrm{ft}^{3} /$ day (STP) per reactor.

Enter on Card 31 the holdup time, in days, for Xe in spaces 73-80.

Enter on Card 32 the holdup time, in days, for $\mathrm{Kr}$ in spaces 73-80.

Enter on Card 33 the fill time, in days, in spaces 73-80.

2. Charcoal Delay Systems

equation:

Charcoal delay system holdup times are based on the following

$T=0.011 \mathrm{MK} / \mathrm{F}$

where

$F \quad$ is the system flow rate, in $\mathrm{ft}^{3} / \mathrm{min}$; (see $1.5 .2 .14 .1 . \mathrm{c}$, above)

$K$ is the dynamic adsorption coefficient, in $\mathrm{cm}^{3} / \mathrm{g}$;

$M$ is the mass of charcoal adsorber, in thousands of pounds; and

$T$ is the holdup time, in days.

The dynamic absorption coefficient, $K$, for $X e$ and $K r$ and based on 
the system design noted below.

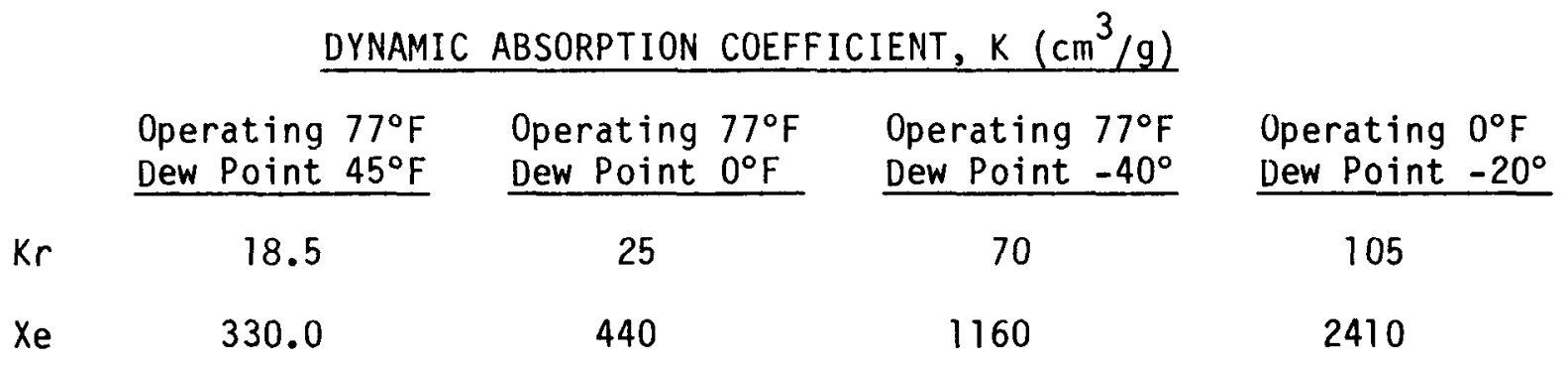

Enter on Card 31 the holdup time, in days, for Xe in spaces 73-80. Enter on Card 32 the holdup time, in days, for $k r$ in spaces $73-80$. Leave Card 33 blank.

3. Cover Gas Recycle System

For this system or other systems designed to hold gases indefinitely, the calculations are based on a 90-day holdup time.

Enter on Card 31 the holdup time (90 days) for Xe in spaces 73-80.

Enter on Card 32 the holdup time (90 days) for $\mathrm{Kr}$ in spaces 73-80.

Enter on Card 33 the fill time (0 days) in spaces $73-80$.

1.5.2.15 Card 34: Waste Gas System Particulate Releases

Card 34 identifies the treatment provided for particulate removal from the waste gas system effluent.

1. If ventilation exhaust air is treated through HEPA filters which satisfy the guidelines of Regulatory Guide 1.140 (Ref. 2), enter a removal efficiency of 99 . for particulates in spaces 39-41.

2. If no treatment is provided for the ventilation exhaust air to remove particulates or if the HEPA filters do not satisfy the guidelines of Regulatory Guide 1.140 (Ref. 2), enter 0.0 in spaces $39-41$.

1.5.2.16 Cards 35 and 36: Fuel Handling and Auxiliary Buildings Releases

Cards 35 and 36 indicate the fractions of airborne iodine and radioactive particulates released from the fuel handling and auxiliary buildings, respectively. 


\section{ASSIGNED REMOVAL EFFICIENCIES FOR CHARCOAL ADSORBERS}

FOR RADIOIODINE REMOVAL

Activated Carbon ${ }^{\mathrm{a}}$ Bed Depth

2 inches. Air filtration system designed to operate inside reactor containment

2 inches. Air filtration system designed to operate outside the reactor containment and relative humidity is controlled at $70 \%$

4 inches. Air filtration system designed to operate outside the reactor containment and relative humidity is controlled at $70 \%$

6 inches. Air filtration system designed to operate outside the reactor containment and relative humidity is controlled to $70 \%$
Removal Efficiencies for Radioiodine \%

a Multiple beds, e.g., two 2-inch beds in series, should be treated as a single bed of aggregate depth of 4 inches.

$b$ The removal efficiencies assigned to HEPA filters for particulate removal and charcoal adsorbers for radioiodine removal are based on the design, testing, and maintenance criteria recommended in Regulatory Guide 1.140, "Design, Testing and Maintenance Criteria for Normal Ventilation Exhaust System Air Filtration and Adsorption Units of Light-Water-Cooled Nuclear Power Plants" (Ref. 2). 
1. If ventilation exhaust air is treated through charcoal adsorbers which satisfy the guidelines of Regulatory Guide 1.140 (Ref. 2), enter the appropriate removal efficiency in spaces 47-49 for radioiodine corresponding to the depth of charcoal as indicated in Table 1-5.

2. If ventilation exhaust air is treated through HEPA filters which satisfy the guidelines of Regulatory Guide 1.140 (Ref. 2), enter a removal efficiency of 99. for particulates in spaces 56-58.

3. If no treatment is provided for the ventilation exhaust air to remove radioiodine, enter 0.0 in spaces $47-49$; if no treatment is provided to remove particulates, enter 0.0 in spaces $56-58$.

\subsubsection{Card 37: Containment Free Volume (SAR/ER)}

Enter the containment volume (in $10^{6} \mathrm{ft}^{3}$ ) in spaces $73-80$.

1.5.2.18 Card 38: Containment Internal Cleanup System (SAR/ER)

1. If the containment internal cleanup system uses charcoal adsorbers which satisfy the guidelines of Regulatory Guide 1.140 (Ref. 2), enter the appropriate removal efficiency in spaces 47-49 for radioiodine corresponding to the depth of charcoal as indicated in Table 1-5.

2. If the containment internal cleanup system uses HEPA filters which satisfy the guidelines of Regulatory Guide 1.140 (Ref. 2), enter a removal efficiency of 99 . for particulates in spaces 56-58.

3. If there is no containment internal cleanup system, enter 0.0 in spaces 47-49 and in spaces 56-58.

4. Enter the flow rate (in $10^{3} \mathrm{ft}^{3} / \mathrm{min}$ ) through the internal cleanup system in spaces $73-80$.

The airborne concentration calculations are based on the following parameters:

a. A primary coolant leakage rate corresponding to the normalized release rate given in Table $1-1$.

b. A continuous normal ventilation flow rate as specified by the applicant.

c. Operation of the cleanup system for 16 hours prior to purging.

d. A DF for the charcoal adsorber corresponding to the values in Table 1-5, a DF of 100 for the HEPA filters, and a mixing efficiency of $70 \%$. The mixing efficiency is an effective removal efficiency which takes into account the effects of incomplete mixing in the containment. 
e. Continuous leakage of primary coolant during the operation of the internal cleanup system.

1.5.2.19 Card 39: Containment Building Iodine Releases - During Large Volume Purge System Operation

Card 39 indicates the fraction of airborne iodine and radioactive particulates released during purging of the containment building with the large volume containment purge system.

Note: Treatment referred to below does not include the internal recirculation system.

1. If ventilation exhaust air is treated through charcoal adsorbers which satisfy the guidelines of Regulatory Guide 1.140 (Ref. 2), enter the appropriate removal efficiency in spaces 47-49 for radioiodine corresponding to the depth of charcoal as indicated in Table 1-5.

2. If ventilation exhaust air is treated through HEPA filters which satisfy the guidelines of Regulatory Guide 1.140 (Ref. 2), enter a removal efficiency of 99 . for particulates in spaces 56-58.

3. If no treatment is provided for the ventilation exhaust air to remove radioiodine, enter 0.0 in spaces 47-49; if no ireatment is provided to remove particulates, enter 0.0 in spaces $56-58$.

4. Enter the number of purges per year during power operations in spaces 78-80. (Note: The 2 purges at shutdown are stored in the PWR GALE Code and need not be entered on card 39.)

\subsubsection{Card 40: Containment Building Iodine Releases - Low Volume} Purge During Power Operation

Card 40 indicates the fraction of airborne iodine in the containment atmosphere that is released during the low volume purge of the containment building while the reactor is at power.

Note: Treatment referred to below does not include the internal recirculation system.

1. If ventilation exhaust air is treated through charcoal adsorbers which satisfy the guidelines of Regulatory Guide 1.140 (Ref. 2), enter the appropriate removal efficiency in spaces 47-49 for radioiodine corresponding to the depth of charcoal as indicated in Table $1-5$.

2. If ventilation exhaust air is treated through HEPA filters which satisfy the guidelines of Regulatory Guide 1.140 (Ref. 2), enter a removal efficiency of 99. for particulates in spaces 56-58.

3. If no treatment is provided for the ventilation exhaust air to remove radioiodine, enter 0.0 in spaces $47-49$; if no treatment is provided to remove particulates, enter 0.0 in spaces $56-58$. 
4. Enter the continuous containment purge rate $\left(\mathrm{ft}^{3} / \mathrm{min}\right)$ in spaces 73-80.

\subsubsection{Card 41: Steam Generator Blowdown Tank Vent}

1. Enter 0.0 in spaces 73-80 if the gases from the blowdown flash tank are vented thro"gh a condenser prior to release.

2. Enter 0.0 in spaces $73-80$ if the blowdown flash tank is vented to the main condenser air ejector.

3. Enter 0.0 in spaces 73-80 for a once-through steam generator system.

4. For older plants which still use flash tanks which vent directly to the atmosphere an iodine partition factor of 0.05 is used.

1.5.2.22 Card 42: Percentage of lodine Removed by the Condenser Air Ejector Offgas Treatment System

1. If, prior to release, the offgases from the condenser air ejector are processed through charcoal adsorbers which satisfy the guidelines of Regulatory Guide 1.140 (Ref. 2), enter the removal efficiency in spaces 73-80 for radioiodine corresponding to the depth of charcoal as indicated in Table $1-5$.

2. If the offgases are released from the condenser air ejector without treatment, enter 0.0 in spaces $73-80$.

\subsubsection{Card 43: Detergent Wastes}

1. If the plant does not have an onsite laundry, enter 0.0 in spaces 73-80.

2. If the plant has an onsite laundry and detergent wastes are released without treatment, enter 1.0 in spaces $73-80$.

3. If detergent wastes are treated prior to discharge, enter the fraction of radionuclides remaining after treatment (1/DF) in spaces 73-80. The parameters in Chapter 2 of this document should be used in determining the DF for the treatment applied to detergent wastes. 
CHAPTER 2. PRINCIPAL PARAMETERS USED IN PWR SOURCE TERM

CALCULATIONS AND THEIR BASES

\section{$2.1 \quad$ INTRODUCTION}

The principal parameters used in source term calculations have been compiled to standardize the calculation of radioactive source terms.

The following sections describe parameters used in the evaluation of radwaste treatment systems. The parameters have been derived from reactor operating experience where data were available. Where operating data were inconclusive or not available, information was drawn from laboratory and field tests and from engineering judgment. The bases for the source term parameters explain the reasons for choosing the numerical values listed. A list of references used in developing the parameters is also included.

The parameters in the PWR-GALE Code will be updated periodically and published in revisions to this NUREG as additional operating data become available. The source term parameters used are believed to provide a realistic assessment of reactor and radwaste system operation.

\subsection{PRINCIPAL PARAMETERS AND THEIR BASES}

\subsubsection{THERMAL POWER LEVEL}

\subsubsection{Parameter}

The maximum thermal power level (MWt) evaluated for safety considerations in the Safety Analysis Report.

\subsubsection{Bases}

The power level used in the source term PWR-GALE Code is the maximum power level evaluated for safety considerations in the Safety Analysis Report. Using this value, the evaluation of the radwaste management systems need not be repeated when the applicant applies for a stretch power license at a later date. Past experience indicates that most utilities request approval to operate at maximum power soon after reaching commercial operation.

\subsubsection{PLANT CAPACITY FACTOR}

\subsubsection{Parameter}

A plant capacity factor of $80 \%$ is used, i.e., 292 effective full power days. 


\subsubsection{Bases}

The source term calculations are based on a plant capacity factor of $80 \%$ averaged over the 30 -year operating 1 ife of the plant, i.e., the plant operates at $100 \%$ power $80 \%$ of the time. The plant capacity factors experienced at PWR's are listed in Table 2-1 for the period 1972 through 1977.

The average plant capacity factors shown in Table 2-1 indicate that the $80 \%$ factor assumed is higher than the average factors experienced. However, it is expected that the major maintenance problems and extended refueling outages that have contributed to the lower plant capacity factors will be overcome and that the plants will achieve the $80 \%$ capacity factor when averaged over 30 years of operation.

\subsubsection{RADIONUCLIDE CONCENTRATIONS IN THE PRIMARY AND SECONDARY COOLANT \\ 2.2.3.1 Parameter}

As used in the PWR-GALE Code, Tables 2-2 and 2-3 list the expected radionuclide concentrations in the reactor coolant and steam for PWR's with design parameters within the ranges listed in Tables 2-4 and 2-5. Should any design parameter be outside the range in Tables 2-4 and 2-5, the PWRGALE Code adjusts the concentrations in Tables $2-2$ and 2-3, using the factors in Tables 2-6, 2-7, and 2-8. Figures 2-1 and 2-2 show the graphical relationship of the design parameters.

\subsubsection{Bases}

The radionuclide concentrations, adjustment factors, and procedure for effecting adjustments are based on the values and methods in American National Standard ANSI N237, Source Term Specification, (Ref. 1) but have been updated based on a recent compilation of available operating data concerning primary coolant concentrations, steam generator tube leakage, and secondary side radionuclide behavior. Therefore, the concentration values in NUREG-0017, Rev. I differ from the ANSI N237 values.

The values in Tables 2-2 and 2-3 provide a set of typical radionuclide concentrations in the primary and secondary systems for reactor designs within the parameters specified in Tables 2-4 and 2-5. The values in Tables 2-2 and 2-3 are those determined to be representative of radionuclide concentrations in a PWR over its lifetime based on the currently available data and models. The secondary coolant concentrations given in Tables 2-2 and 2-3 are calculated by using the reference parameters given in Table 2-6 and the equations given in Tables 2-7 and 2-8. It is recognized that some systems will have design parameters that are outside the ranges specified in Tables 2-4 and 2-5. For that reason, a means of adjusting the concentrations to the actual design parameters has been provided in Tables 2-6 through 2-8. The adjustment factors in Table 2-6 through 2-8 are based on the following expression; 
TABLE 2-1

\section{PLANT CAPACITY FACTORS AT OPERATING PWR's ${ }^{\mathrm{a}}$}

\begin{tabular}{|c|c|c|c|c|c|c|c|}
\hline FACILITY & $\begin{array}{l}\text { Date of } \\
\text { Commercial } \mathrm{c} \\
\text { Operation } \\
\end{array}$ & 1972 & 1973 & 1974 & 1975 & 1976 & 1977 \\
\hline $\begin{array}{l}\text { Haddam Neck } \\
\text { San Onofre 1 } \\
\text { R. E. Ginna } \\
\text { Point Beach 1 } \\
\text { H. B. Robinson } 2 \\
\text { Palisades } \\
\text { Point Beach 2 } \\
\text { Turkey Point } 3 \\
\text { Surry 1 } \\
\text { Maine Yankee } \\
\text { Surry 2 } \\
\text { Oconee 1 } \\
\text { Indian Point } 2 \\
\text { Turkey Point } 4 \\
\text { Fort Calhoun } \\
\text { Prairie Island } 1 \\
\text { Zion 1 } \\
\text { Kewaunee } \\
\text { Three Mile Is land } 1 \\
\text { Oconee 2 } \\
\text { Zion 2 } \\
\text { Oconee } 3 \\
\text { Arkansas } 1 \\
\text { Prairie Island } 2 \\
\text { Rancho Seco } \\
\text { Calvert Cliffs } 1 \\
\text { Cook } 1 \\
\text { Millstone } 2 \\
\text { Trojan } \\
\text { Indian Point } 3 \\
\text { Beaver Valley } 1 \\
\text { St. Lucie } 1\end{array}$ & $\begin{array}{l}1 / 68 \\
1 / 68 \\
7 / 70 \\
12 / 70 \\
3 / 71 \\
12 / 71 \\
10 / 72 \\
12 / 72 \\
12 / 72 \\
12 / 72 \\
5 / 73 \\
7 / 73 \\
8 / 73 \\
9 / 73 \\
9 / 73 \\
12 / 73 \\
12 / 73 \\
6 / 74 \\
9 / 74 \\
9 / 74 \\
9 / 74 \\
12 / 74 \\
12 / 74 \\
12 / 74 \\
4 / 75 \\
5 / 75 \\
8 / 75 \\
12 / 75 \\
5 / 76 \\
8 / 76 \\
10 / 76 \\
12 / 76\end{array}$ & $\begin{array}{l}86 \\
72 \\
58 \\
69 \\
78 \\
61\end{array}$ & $\begin{array}{l}48^{\mathrm{d}} \\
60 \\
81 \\
67 \\
65 \\
40^{\mathrm{e}} \\
72 \\
55 \\
51 \\
17^{f}\end{array}$ & $\begin{array}{l}89 \\
83 \\
50^{d} \\
76 \\
81 \\
d \\
77 \\
61 \\
50^{d} \\
54 \\
40^{d} \\
54 \\
51 \\
71 \\
61 \\
36 \\
49^{\mathrm{e}}\end{array}$ & $\begin{array}{l}84 \\
85 \\
73 \\
70 \\
71 \\
46 \\
88 \\
76 \\
60 \\
69 \\
76 \\
71 \\
68 \\
68 \\
54 \\
83 \\
68 \\
75 \\
79 \\
68 \\
68 \\
69 \\
69 \\
73\end{array}$ & $\begin{array}{l}81 \\
66 \\
52 \\
78 \\
82 \\
50^{d} \\
86 \\
75 \\
67 \\
91 \\
57 \mathrm{e} \\
54{ }^{2} \\
31 \\
64 \\
57 \\
73 \\
55 \\
75 \\
63 \\
58 \\
54 \\
64 \\
54 \\
69 \\
28 \\
88 \\
75 \\
68\end{array}$ & $\begin{array}{l}82 \\
62 \\
83 \\
85 \\
74 \\
78 \\
82 \\
78 \\
78 \\
77 \\
65 \\
54 \\
73 \\
62 \\
76 \\
83 \\
58 \\
77 \\
79 \\
53 \\
71 \\
71 \\
73 \\
87 \\
75 \\
65 \\
54 \mathrm{f} \\
63 \\
71 \\
72 \\
44 \mathrm{e} \\
78\end{array}$ \\
\hline AVERAGE & & 71 & 64 & 69 & 72 & 69 & 74 \\
\hline
\end{tabular}

a From monthly Operating Units Status Reports.

$b$ Indian Point 1 and Yankee Rowe are not included since they are small reactors $[<700 \mathrm{MW}(\mathrm{t})]$.

$C$ Plant capacity factors listed are for the first full year of commercial operation. Therefore, this list does not include the following plants which began commercial operation in 1977 and 1978: Calvert Cliffs 2, Cook 2, Crystal River 3, Davis Besse 1, Farley 1, Salem 1, North Anna 1, and Three Mile Island 2.

${ }^{d}$ Not included due to extended outage for refueling/amintenance.

e Not included due to extended maintenance/repair to the secondary system.

$f$ Not included due to extended operation at reudced power.

${ }^{g}$ Not included due to extended maintenance outage to repair generator. 
TABLE 2-2

NUMERICAL VALUES - CONCENTRATIONS IN PRINCIPAL FLUID STREAMS OF THE REFERENCE PWR WITH U-TUBE STEAM GENERATORS

$$
(\mu \mathrm{Ci} / \mathrm{g})
$$

$\begin{array}{lc} & \\ \text { Isotope } & \text { Reactor Coolant } \\ \text { Noble Gases } & \\ \mathrm{Kr}-85 \mathrm{~m} & \\ \mathrm{Kr}-85 & 1.6(-1)^{\dagger+\dagger} \\ \mathrm{Kr}-87 & 4.3(-1) \\ \mathrm{Kr}-88 & 1.5(-1) \\ \mathrm{Xe}-131 \mathrm{~m} & 2.8(-1) \\ \mathrm{Xe}-133 \mathrm{~m} & 7.3(-1) \\ \mathrm{Xe}-133 & 7.0(-2) \\ \mathrm{Xe}-135 \mathrm{~m} & 2.6(0) \\ \mathrm{Xe}-135 & 1.3(-1) \\ \mathrm{Xe}-137 & 8.5(-1) \\ \mathrm{Xe}-138 & 3.4(-2) \\ & 1.2(-1)\end{array}$

$\frac{\text { Secondary Coolant* }}{\text { Water }^{* \star}}$

Ha logens

$\mathrm{Br}-84$

I -131

$1-132$

$1-133$

I -134

$\mathrm{I}-135$

Cs, Rb

$\mathrm{Rb}-88$

Cs -134

Cs-136

Cs-137

$$
\begin{aligned}
& 1.6(-2) \\
& 4.5(-2) \\
& 2.1(-1) \\
& 1.4(-1) \\
& 3.4(-1) \\
& 2.6(-1)
\end{aligned}
$$

$7.5(-8)$

$1.8(-6)$

$3.1(-6)$

$4.8(-6)$

$2.4(-6)$

$6.6(-6)$

$3.4(-8)$

$8.9(-8)$

$3.0(-8)$

$5.9(-8)$

$1.5(-7)$

$1.5(-8)$

$5.4(-7)$

$2.7(-8)$

$1.8(-7)$

$7.1(-9)$

$2.5(-8)$

$7.5(-10)$

$1.8(-8)$

$3.1(-8)$

$4.8(-8)$

$2.4(-8)$

$6.6(-8)$

Water Activation Products

$\mathrm{N}-16$

$4.0(+1)$

$5.3(-7)$

$3.3(-7)$

$4.0(-8)$

$4.4(-7)$

2.6(-9)

$1.7(-9)$

$2.0(-10)$

2.2(-9)

$8.7(-4)$

$9.4(-3)$

Tritium

H-3

$1.0(0)$

$1.0(-3)$

$1.0(-3)$

Other Nuclides

$\mathrm{Na}-24$

$\mathrm{Cr}-51$

$M n-54$

$4.7(-2)$
$3.1(-3)$
$1.6(-3)$

$1.5(-6)$
$1.3(-7)$
$6.5(-8)$

$7.5(-9)$

$6.3(-10)$

$3.3(-10)$ 
TABLE 2-2 (continued)

\begin{tabular}{|c|c|c|c|}
\hline \multirow[b]{2}{*}{ Isotope } & \multirow[b]{2}{*}{ Reactor Coolant** } & \multicolumn{2}{|c|}{ Secondary Coolant* } \\
\hline & & Water $\star \star \star$ & Steam $^{\dagger \dagger}$ \\
\hline $\begin{array}{l}\text { Fe-55 } \\
\text { Fe-59 } \\
\text { Co-58 } \\
\text { Co-60 } \\
\mathrm{Zn}-65 \\
\mathrm{Sr}-89 \\
\mathrm{Sr}-90 \\
\mathrm{Sr}-91 \\
\mathrm{Y}-91 \mathrm{~m} \\
\mathrm{Y}-91 \\
\mathrm{Y}-93 \\
\mathrm{Zr}-95 \\
\mathrm{Nb}-95 \\
\mathrm{Mo}-99 \\
\mathrm{Tc}-99 \mathrm{~m} \\
\mathrm{Ru}-103 \\
\mathrm{Ru}-106 \\
\mathrm{Ag}-110 \mathrm{~m} \\
\mathrm{Te}-129 \mathrm{~m} \\
\mathrm{Te}-129 \\
\mathrm{Te}-131 \mathrm{~m} \\
\mathrm{Te}-131 \\
\mathrm{Te}-132 \\
\mathrm{Ba}-140 \\
\mathrm{La}-140 \\
\mathrm{Ce}-141 \\
\mathrm{Ce}-143 \\
\mathrm{Ce}-144 \\
\mathrm{~W}-187 \\
\mathrm{~Np}-239\end{array}$ & $\begin{array}{l}1.2(-3) \\
3.0(-4) \\
4.6(-3) \\
5.3(-4) \\
5.1(-4) \\
1.4(-4) \\
1.2(-5) \\
9.6(-4) \\
4.6(-4) \\
5.2(-6) \\
4.2(-3) \\
3.9(-4) \\
2.8(-4) \\
6.4(-3) \\
4.7(-3) \\
7.5(-3) \\
9.0(-2) \\
1.3(-3) \\
1.9(-4) \\
2.4(-2) \\
1.5(-3) \\
7.7(-3) \\
1.7(-3) \\
1.3(-2) \\
2.5(-2) \\
1.5(-4) \\
2.8(-3) \\
3.9(-3) \\
2.5(-3) \\
2.2(-3)\end{array}$ & $\begin{array}{l}4.9(-8) \\
1.2(-8) \\
1.9(-7) \\
2.2(-8) \\
2.1(-8) \\
5.7(-9) \\
4.9(-10) \\
2.8(-8) \\
3.2(-9) \\
2.1(-10) \\
1.2(-7) \\
1.6(-8) \\
1.1(-8) \\
2.5(-7) \\
1.1(-7) \\
3.1(-7) \\
3.7(-6) \\
5.3(-8) \\
7.8(-9) \\
2.2(-7) \\
5.4(-8) \\
2.9(-8) \\
6.6(-8) \\
5.2(-7) \\
9.3(-7) \\
6.1(-9) \\
1.0(-7) \\
1.6(-7) \\
8.7(-8) \\
8.4(-8)\end{array}$ & $\begin{array}{l}2.5(-10) \\
6.1(-11) \\
9.4(-10) \\
1.1(-10) \\
1.0(-10) \\
2.9(-11) \\
2.5(-12) \\
1.4(-10) \\
1.6(-11) \\
1.1(-12) \\
6.1(-10) \\
7.9(-11) \\
5.7(-11) \\
1.2(-9) \\
5.7(-10) \\
1.6(-9) \\
1.8(-8) \\
2.7(-10) \\
3.9(-11) \\
1.1(-9) \\
2.7(-10) \\
1.5(-10) \\
3.3(-10) \\
2.6(-9) \\
4.6(-9) \\
3.1(-11) \\
5.1(-10) \\
8.2(-10) \\
4.4(-10) \\
4.2(-10)\end{array}$ \\
\hline
\end{tabular}

* Based on a primary-to-secondary leak of $75 \mathrm{lb} / \mathrm{day}$.

** The concentrations given are for reactor coolant entering the letdown 1ine. These concentrations are obtained from Tables 2-9 and 2-10. $\mathrm{N}-16$ and $\mathrm{H}-3$ concentrations are obtained from Reference 1.

$\star \star \star$ The concentrations given are for water in a steam generator.

†t The concentrations given are for steam leaving a steam generator. $+t t 1.6(-1)=1.6 \times 10^{-1}$. 
TABLE 2-3

NUMERICAL VALUES - CONCENTRATIONS IN PRINCIPAL FLUID STREAMS

OF THE REFERENCE PWR WITH ONCE-THROUGH STEAM GENERATORS

$$
\left({ }_{\mu} \mathrm{Ci} / \mathrm{g}\right)
$$

Is otope

Noble Gases
Reactor Coolant*

$$
\begin{aligned}
& 1.6(-1) \\
& 4.3(-1) \\
& 1.5(-1) \\
& 2.8(-1) \\
& 7.3(-1) \\
& 7.0(-2) \\
& 2.6(0) \\
& 1.3(-1) \\
& 8.5(-1) \\
& 3.4(-2) \\
& 1.2(-1)
\end{aligned}
$$

$\mathrm{Xe}-137$

$\mathrm{Xe}-138$

Ha logens

$\mathrm{Br}-84$

I -131

$\mathrm{I}-132$

I -133

I-134

I -135

Cs, Rb
$\mathrm{Rb}-88$
Cs-134
Cs-136
Cs-137
$1.9(-1)$
$7.1(-3)$
$8.7(-4)$
$9.4(-3)$

$1.6(-2)$

$4.5(-2)$

$2.1(-1)$

$1.4(-1)$

$3.4(-1)$

$2.6(-1)$
Secondary Coolant**

$3.4(-8)$
$8.9(-8)$
$3.0(-8)$
$5.9(-8)$
$1.5(-7)$
$1.5(-8)$
$5.4(-7)$
$2.7(-8)$
$1.8(-7)$
$7.1(-9)$
$2.5(-8)$

$1.8(-8)$

$5.2(-8)$

$2.4(-7)$

$1.6(-7)$

$3.8(-7)$

$3.0(-7)$
Water Activation Products

$\mathrm{N}-16$

Tritium

H-3

$1.0(0)$

$4.0(+1)$
$6.0(-7)$

$3.0(-8)$

$3.6(-9)$

$3.9(-8)$

Other Nuclides
$\mathrm{Na}-24$
$\mathrm{Cr}-51$
$\mathrm{Mn}-54$
$\mathrm{Fe}-55$
$\mathrm{Fe}-59$
Co-58
Co-60

$1.0(-6)$

$1.0(-3)$ 
TABLE 2-3 (continued)

\begin{tabular}{l} 
Isotope \\
\hline $\mathrm{Zn}-65$ \\
$\mathrm{Sr}-89$ \\
$\mathrm{Sr}-90$ \\
$\mathrm{Sr}-91$ \\
$\mathrm{Y}-91 \mathrm{~m}$ \\
$\mathrm{Y}-91$ \\
$\mathrm{Y}-93$ \\
$\mathrm{Zr}-95$ \\
$\mathrm{Nb}-95$ \\
$\mathrm{Mo}-99$ \\
$\mathrm{Tc}-99 \mathrm{~m}$ \\
$\mathrm{Ru}-103$ \\
$\mathrm{Ru}-106$ \\
$\mathrm{Ag}-110 \mathrm{~m}$ \\
$\mathrm{Te}-129 \mathrm{~m}$ \\
$\mathrm{Te}-129$ \\
$\mathrm{Te}-131 \mathrm{~m}$ \\
$\mathrm{Te}-131$ \\
$\mathrm{Te}-132$ \\
$\mathrm{Ba}-140$ \\
$\mathrm{La}-140$ \\
$\mathrm{Ce}-141$ \\
$\mathrm{Ce}-143$ \\
$\mathrm{Ce}-144$ \\
$\mathrm{~W}-187$ \\
$\mathrm{~Np}-239$ \\
\hline
\end{tabular}

Reactor Coolant*

$5.1(-4)$

$1.4(-4)$

$1.2(-5)$

$9.6(-4)$

$4.6(-4)$

$5.2(-6)$

$4.2(-3)$

$3.9(-4)$

$2.8(-4)$

$6.4(-3)$

$4.7(-3)$

$7.5(-3)$

$9.0(-2)$

$1.3(-3)$

$1.9(-4)$

$2.4(-2)$

$1.5(-3)$

$7.7(-3)$

$1.7(-3)$

$1.3(-2)$

$2.5(-2)$

$1.5(-4)$

$2.8(-3)$

$3.9(-3)$

$2.5(-3)$

$2.2(-3)$
Secondary Coolant**

1.1(-9)

$3.1(-10)$

$2.7(-11)$

$2.7(-9)$

9.7 $(-10)$

$1.2(-11)$

9.3(-9)

$8.7(-10)$

$6.2(-10)$

$1.4(-8)$

$1.0(-8)$

$1.7(-8)$

$2.0(-7)$

2.9(-9)

4.2(-10)

$5.1(-8)$

$3.3(-9)$

$1.5(-8)$

$3.8(-9)$

$2.9(-8)$

$5.6(-8)$

$3.3(-10)$

6.2(-9)

$8.7(-9)$

$5.6(-9)$

4.9(-9)

* The concentrations given are reactor coolant entering the letdown line. These concentrations are obtained from Tables 2-9 and 2-10. N-16 and H-3 concentrations are obtained from Reference 1.

** Based on primary-to-secondary leakage of $75 \mathrm{lb} /$ day. The concentrations given are for stean leaving a steam generator. 
TABLE 2-4

PARAMETERS USED TO DESCRIBE THE REFERENCE PRESSURIZED WATER

REACTOR WITH U-TUBE STEAM GENERATORS

Parameter

Thermal Power

Steam flow rate

Weight of water in reactor coolant system

Weight of water in all steam generators

Reactor coolant letdown flow (purification)

Reactor coolant letdown flow (yearly average for boron control)

Steam generator blowdown flow (total)

Fraction of radioactivity in blowdown stream that is not returned to the secondary coolant system

Flow through the purification system cation demineralizer

Ratio of condensate demineralizer flow rate to the total steam flow rate

Ratio of the total amount of noble gases routed to gaseous radwaste from the purification system to the total amount of noble gases routed from the primary coolant system to the purification system (not including the boron recovery system)
Nominal

Symbol Units Value

3,400

$1 \mathrm{~b} / \mathrm{hr}$

$1.5(7)$

$5.5(5)$

$4.5(5)$

$5.0(5)$

$4.0(5)$

WS

FD

Ib/hr

$3.7(4)$

4. 2(4)

$3.2(4)$

FB

$\mathrm{lb} / \mathrm{hr}$

500

1,000

250

FBD

Tb/hr

75,000

100,000

50,000

NBD

$-1.0^{\star}$

1.0

0.9

FA

$\mathrm{lb} / \mathrm{hr}$

3,700

7,500

0.0

NC

$--\quad 0.0 * \star$

0.01

0.0

Y

0.0

0.01

0.0

* This value is based on a nominal case of blowdown through blowdown demineralizers back to the main condenser (no condensate demineralizers). Value taken from blowdown demineralizer DF's in Section 2.2.18. Value for cesium and rubidium is 0.9 .

* This value is based on a nominal case of no condensate demineralizers. For a U-tube steam generator PWR with full flow condensate demineralizers, a value of $N C=1.0$ is used by the PWR-GALE Code. For a U-tube steam generator PWR with condensate demineralizers and pumped forward feedwater heater drains, the value for NC used by the PWR-GALE Code is 0.2 for iodine, and 0.1 for Cs, Rb and other nuclides as discussed on page 2-20. 
TABLE 2-5

PARAMETERS USED TO DESCRIBE THE REFERENCE PRESSURIZED WATER

REACTOR WITH ONCE-THROUGH STEAM GENERATORS

Parameter

Thermal Power

Steam flow rate

Weight of water in reactor coolant system

Weight of water in all steam generators

Reactor coolant letdown flow (purification)

Reactor coolant letdown flow (yearly average for boron control)

Flow through the purification system cation demineralizer

Ratio of condensate demineralizer flow rate to the total steam flow rate

Ratio of the total amount of noble gases routed to gaseous radwaste from the purification system to the total amount routed from the primary coolant system to the purification system (not including the boron recovery system)

\begin{tabular}{|c|c|c|c|c|}
\hline \multirow[b]{2}{*}{ Symbol } & \multirow[b]{2}{*}{ Units } & \multirow{2}{*}{$\begin{array}{c}\text { Nominal } \\
\text { Value } \\
\end{array}$} & \multicolumn{2}{|c|}{ Range } \\
\hline & & & Maximum & Minimum \\
\hline$P$ & MWt & 3,400 & 3,800 & 3,000 \\
\hline FS & $1 \mathrm{~b} / \mathrm{hr}$ & $1.5(7)$ & $1.7(7)$ & $1.3(7)$ \\
\hline WP & $1 b$ & $5.5(5)$ & $6.0(5)$ & $5.0(5)$ \\
\hline WS & $1 b$ & $1.0(5)$ & * & * \\
\hline FD & $1 \mathrm{~b} / \mathrm{hr}$ & $3.7(4)$ & $4.2(4)$ & $3.2(4)$ \\
\hline FB & $1 \mathrm{~b} / \mathrm{hr}$ & 500 & 1,000 & 250 \\
\hline FA & $1 \mathrm{~b} / \mathrm{hr}$ & 3,700 & 7,500 & 0.0 \\
\hline NC & -- & $0.65 \star \star$ & 0.75 & 0.55 \\
\hline$Y$ & -- & 0.0 & 0.01 & 0.0 \\
\hline
\end{tabular}

* The secondary coolant inventory is not of importance in a once-through steam generator plant because decay is not an important removal mechanism for most of the isotopes.

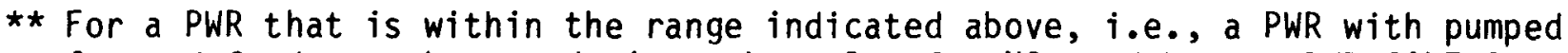
forward feedwater heater drains, the value for NC used by the PWR-GALE Code is 0.2 for iodine and 0.1 for $C S$, Rb and other nuclides, as discussed on page 2-20. For a PWR that has full flow condensate demineralizer, a value of $N C=1.0$ is used by the PWR-GALE Code. 
TABLE 2-6

VALUES USED IN DETERMINING ADJUSTMENT FACTORS FOR

PRESSURIZED WATER REACTORS

Element Class

\begin{tabular}{|c|c|c|c|c|c|c|c|}
\hline Symbol & Description & $\begin{array}{l}\text { Noble } \\
\text { Gases }\end{array}$ & Ha logens & Cs, Rb & $\begin{array}{l}\text { Water } \\
\text { Activation } \\
\text { Products } \\
\end{array}$ & $\mathrm{H}-3$ & $\begin{array}{l}\text { Other } \\
\text { Nuclides }\end{array}$ \\
\hline NA & $\begin{array}{l}\text { Fraction of material } \\
\text { removed in passing } \\
\text { through the cation } \\
\text { demineralizer }\end{array}$ & 0.0 & 0.0 & 0.9 & 0.0 & 0.0 & $0.9 *$ \\
\hline NB & $\begin{array}{l}\text { Fraction of material } \\
\text { removed in passing } \\
\text { through the purification } \\
\text { demineralizer }\end{array}$ & 0.0 & 0.99 & 0.5 & 0.0 & 0.0 & 0.98 \\
\hline$R$ & $\begin{array}{l}\text { Removal rate }=1 \text { reactor } \\
\text { coolant }\left(\mathrm{Hr}^{-1}\right)_{\star \star}\end{array}$ & 0.0009 & 0.067 & 0.037 & 0.0 & $\star \star \star$ & 0.066 \\
\hline \multirow[t]{3}{*}{ NS } & $\begin{array}{l}\text { Ratio of concentration in } \\
\text { steam to that in water } \\
\text { in the steam generator }\end{array}$ & & & & & & \\
\hline & U-tube steam generator & $t$ & 0.01 & 0.005 & t十 & 1.0 & 0.005 \\
\hline & $\begin{array}{l}\text { Once-through steam } \\
\text { generator }\end{array}$ & $\begin{array}{l}t \\
+\end{array}$ & 1.0 & 1.0 & 1.0 & 1.0 & 1.0 \\
\hline$N X$ & $\begin{array}{l}\text { Fraction of activity } \\
\text { removed in passing } \\
\text { through the condensate } \\
\text { demineralizers }\end{array}$ & 0.0 & 0.9 & 0.5 & 0.0 & 0.0 & 0.9 \\
\hline \multirow[t]{3}{*}{$r$} & $\begin{array}{l}\text { Removal rate }=1 \text { secondary } \\
\text { coolant }\left(\mathrm{Hr}^{-1}\right) \mathrm{ttt}\end{array}$ & & & & & & \\
\hline & U-tube steam generator & $\dagger$ & 0.17 & 0.15 & t十 & $\star \star \star$ & 0.17 \\
\hline & $\begin{array}{l}\text { Once-through steam } \\
\text { generator }\end{array}$ & $t$ & 27 & 7.5 & $t \dagger$ & $\star \star \star \star$ & 14 \\
\hline $\mathrm{FL}$ & $\begin{array}{l}\text { Primary-to-secondary } \\
\text { leakage (1b/day) }\end{array}$ & 75 & 75 & 75 & 75 & 75 & 75 \\
\hline
\end{tabular}

* These represent effective removal terms and include mechanisms such as plateout. Plateout would be applicable to nuclides such as Mo and corrosion products. 
** These values of $R$ apply to the reference PWR's whose parameters are given in Tables 2-4 and 2-5 and have been used in developing Tables 2-7 and 2-8. For PWR's not included in Tables 2-4 and 2-5, the appropriate value for $R$ may be determined by the following equations.

$$
\begin{aligned}
& R=\frac{F B+(F D-F B) Y}{W P} \text { for noble gases } \\
& R=\frac{(F D)(N B)+(1-N B)(F B+(F A)(N A))}{W P} \text { for halogens, } C s, R b \text {, and other nuclides }
\end{aligned}
$$

*** The concentration of tritium is a function of (1) the inventory of tritiated liquids in the plant, (2) the rate of production of tritium due to activation in the reactor coolant as well as releases from the fuel, and (3) the extent to which tritiated water is recycled or discharged from the plant. The tritium concentrations given in Tables 2-2 and 2-3 are representative of PWR's with a moderate amount of tritium recycle and can be used to calculate source terms in accordance with Regulatory Guide 1.112, "Calculations of Releases of Radioactive Materials in Gaseous and Liquid Effluents from Light-Water-Cooled Power Reactors."

$+\quad$ Noble gases are rapidly transported out of the water in the steam generator and swept out of the vessel in the steam; therefore, the concentration in the water is negligible and the concentration in the steam is approximately equal to the ratio of the release rate to the steam generator and the steam flow rate. These noble gases are removed from the system at the main condenser.

t† Water activation products exhibit varying chemical and physical properties in reactor coolants that are not well defined. Most are not effectively removed by the demineralizers, but their concentrations are controlled by decay.

ttt These values of $r$ apply to the reference PWR's whose parameters are given in Tables 2-4 and 2-5 and have been used in developing Tables 2-7 and 2-8. For PWR's not included in Tables 2-4 and 2-5, the appropriate value for $r$ may be determined by the following equation:

$$
r=\frac{(F B D)(N B D)+(N S)(F S)(N C)(N X)}{W S} \text { for halogens, } C s, R b \text {, and other nuclides }
$$


TABLE 2-7

ADJUSTMENT FACTORS FOR PWR'S WITH U-TUBE STEAM GENERATORS

Adjustment Factors

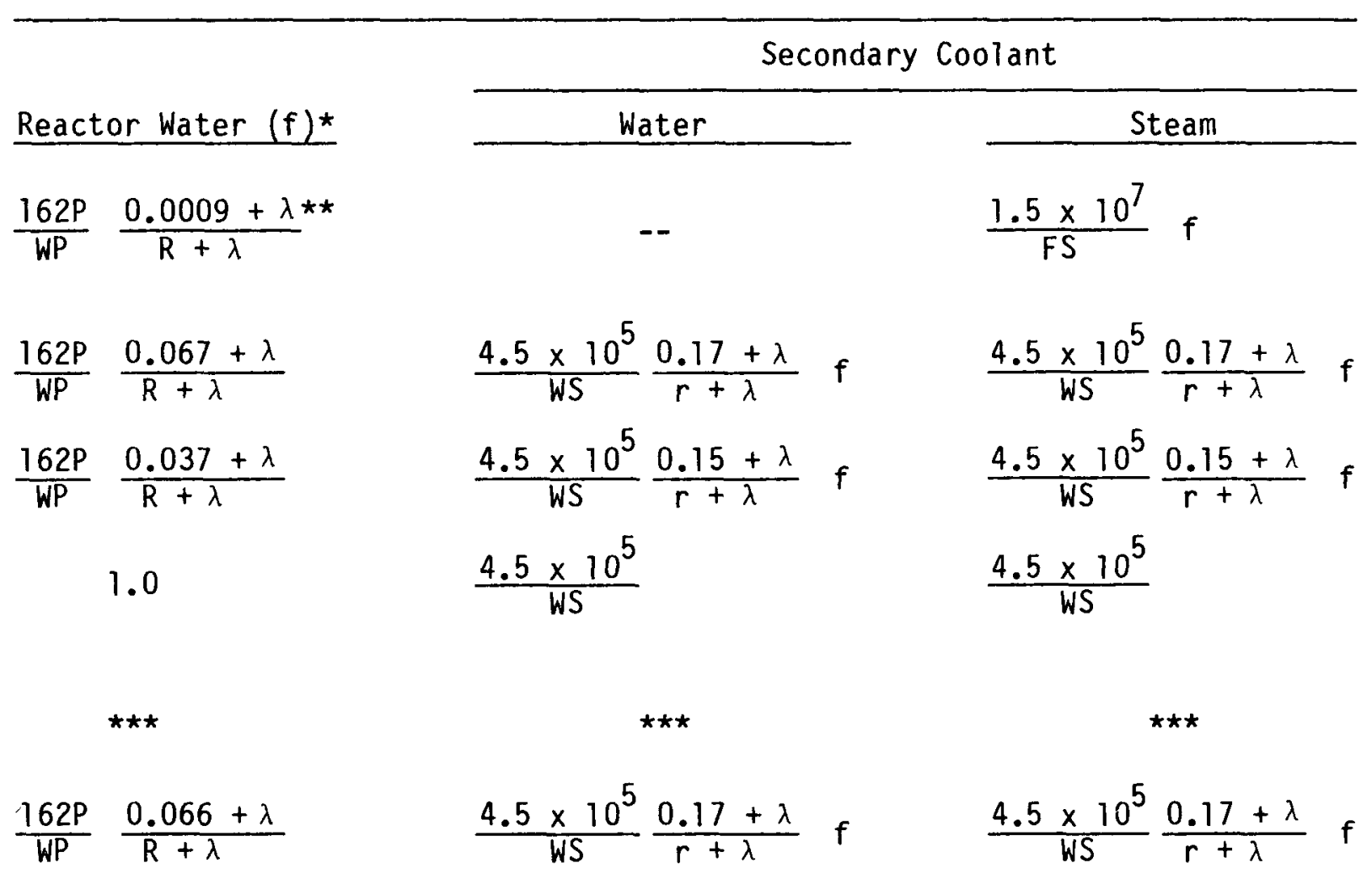

* $f$ is the reactor water adjustment factor and is used in the secondary coolant adjustment factors.

** $\lambda$ is the isotopic decay constant $\left(h r^{-1}\right)$.

$\star \star \star$ The concentration of tritium is a function of (1) the inventory of tritiated liquids in the plant, (2) the rate of production of tritium due to activation in the reactor coolant as well as releases from the fuel, and (3) the extent to which tritiated water is recycled or discharged from the plant. The tritium concentrations given in Tables 2-2 and 2-3 are representative of PWR's with a moderate amount of tritium recycle and can be used to calculate source terms in accordance with Regulatory Guide 1.112 . 
TABLE 2-8

ADJUSTMENT FACTORS FOR PWR'S WITH ONCE-THROUGH STEAM GENERATORS

Adjustment Factors

Nuclide

Noble gases

Ha logens

$\mathrm{Cs}, \mathrm{Rb}$

Water activation products

Reactor Water $(f)^{\star}$

$\frac{162 P}{W P} \frac{0.0009+\lambda}{R+\lambda}$

$\frac{162 P}{W P} \frac{0.067+\lambda}{R+\lambda}$

$\frac{162 P}{W P} \frac{0.037+\lambda}{R+\lambda}$

1.0

$\star \star$

Tritium

Other nuclides

$$
\frac{162 P}{W P} \frac{0.066+\lambda}{R+\lambda}
$$

Secondary Coolant

$\frac{1.5 \times 10^{7}}{\mathrm{FS}} \mathrm{f}$

$\frac{10^{5}}{W S}\left(\frac{27+\lambda}{r+\lambda}\right) f$

$\frac{10^{5}}{W S}\left(\frac{7.5+\lambda}{r+\lambda}\right) f$

$\frac{1.0 \times 10^{5}}{W S}$

$\star \star$

$\frac{10^{5}}{W S}\left(\frac{14+\lambda}{r+\lambda}\right) f$

* $f$ is the reactor water adjustment factor and is used in the secondary coolant adjustment factors.

** The concentration of tritium is a function of (1) the inventory of tritiated liquids in the plant, (2) the rate of production of tritium due to activation in the reactor coolant as well as releases from the fuel, and (3) the extent to which tritiated water is recycled or discharged from the plant. The tritium concentrations given in Tables 2-2 and 2-3 are representative of PWR's with a moderate amount of tritium recycle and can be used to calculate source terms in accordance with the Regulatory Guide 1.112. 


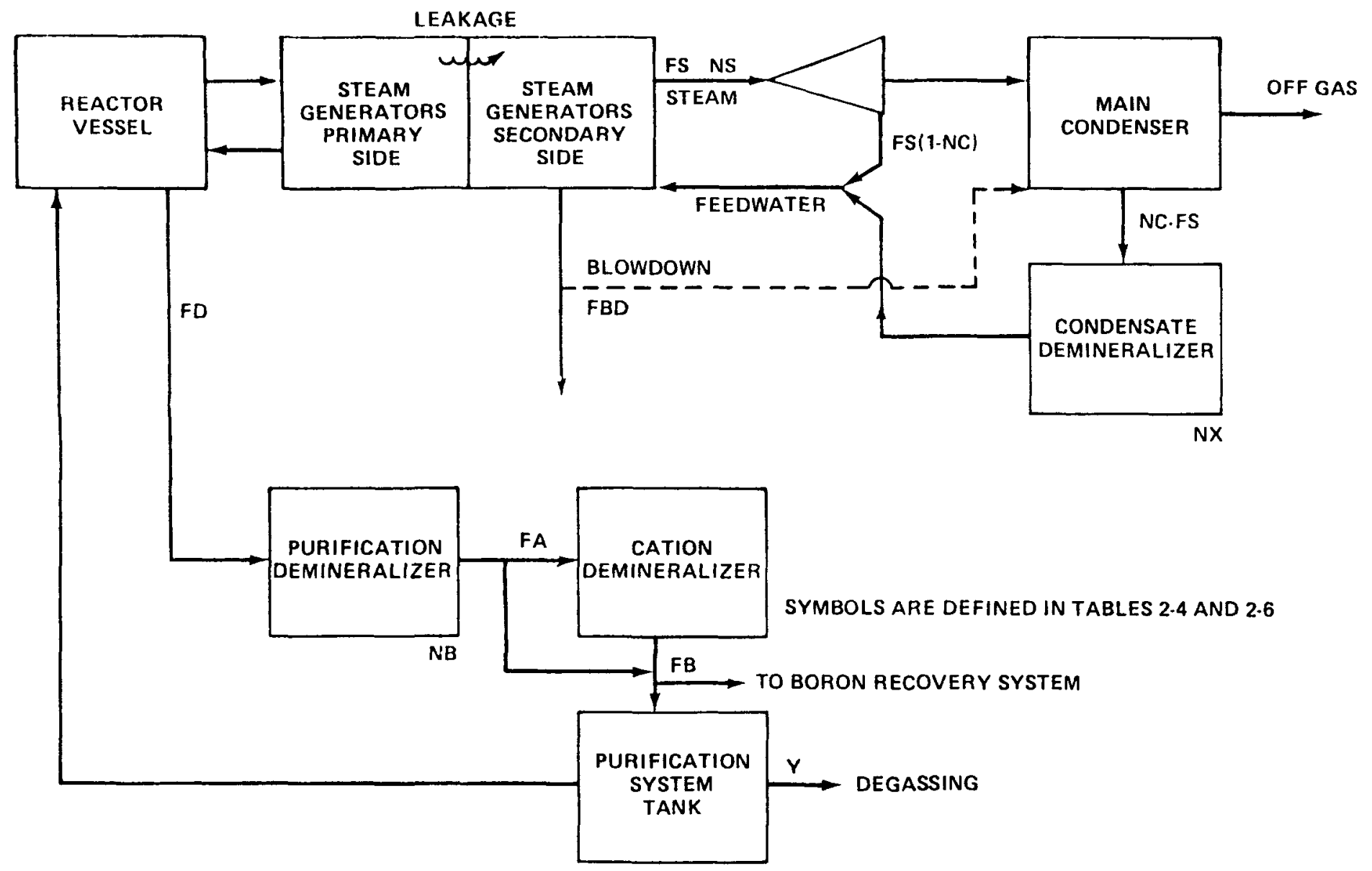

FIGURE 2.1 REMOVAL PATHS FOR PRESSURIZED WATER REACTOR WITHU.TUBE STEAM GENERATORS 


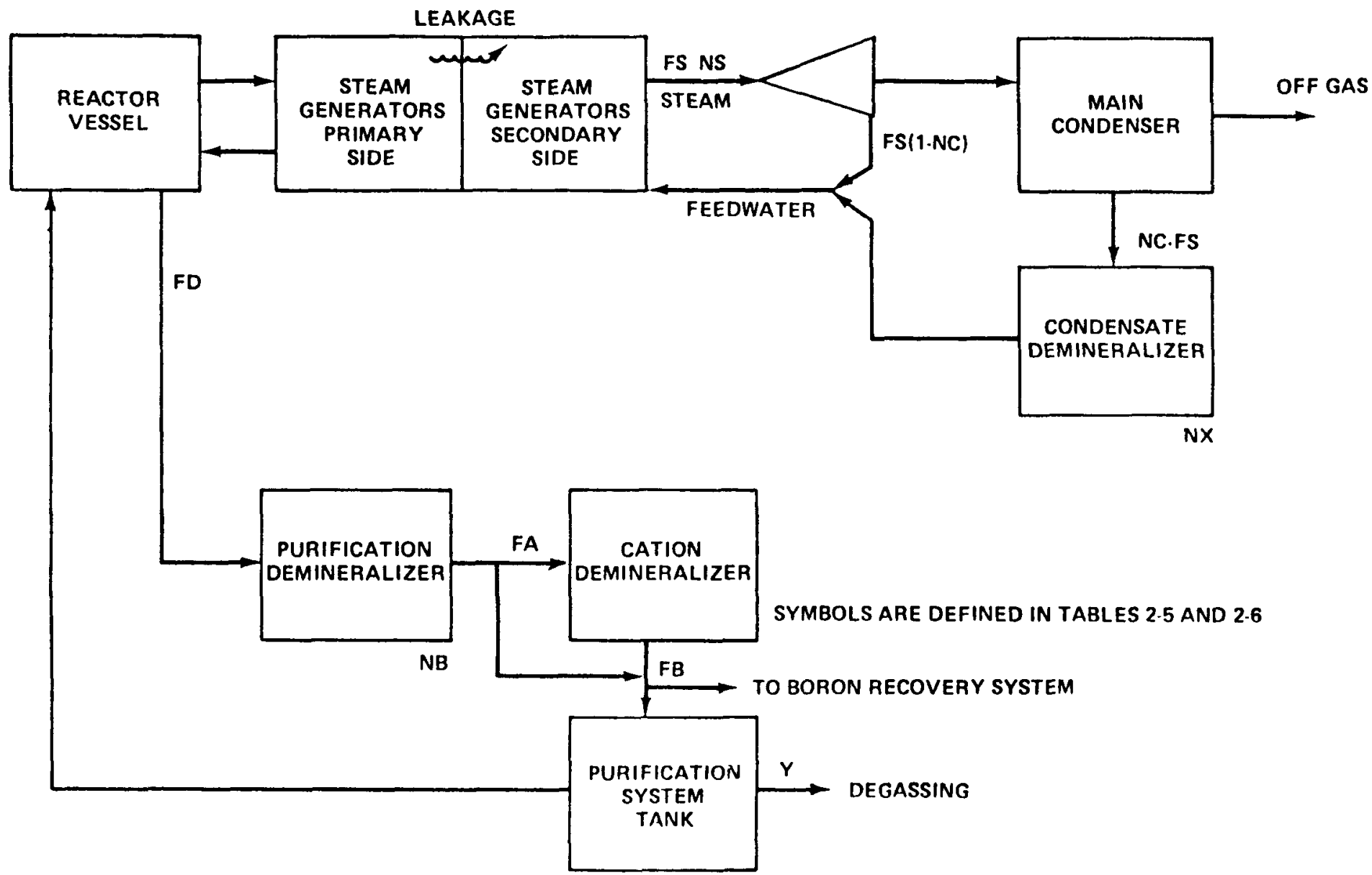

FIGURE 2.2 REMOVAL PATHS FOR PRESSURIZED WATER REACTOR WITH ONCE.THROUGH STEAM GENERATORS 


$$
C=\frac{s}{w(\lambda+R) k}
$$

where

C is the specific activity (in $\mu \mathrm{Ci} / \mathrm{g}$ )

$K$ is a conversion factor, $454 \mathrm{~g} / 1 \mathrm{~b}$

$R$ is the removal rate of the isotope from the system due to demineralization, leakage, etc. $\left(h r^{-l}\right)$. (If considering secondary coolant $R=r$ ).

$s$ is the rate of release to and/of production of the isotope in the system (in $\mu \mathrm{Ci} / \mathrm{hr}$ )

$w$ is the fluid weight (in 1b), and

is the decay constant $\left(h r^{-1}\right)$.

The following sample calculations illustrate the method by which the PWR-GALE Code will adjust the radionuclide concentrations in Tables 2-2 and 2-3. As indicated in Tables 2-7 and 2-8, adjustment factors will be calculated for noble gases, halogens, $\mathrm{Cs}, \mathrm{Rb}$, and other nuclides.

As an example, the sample case parameters shown below compare with the range of values in Table 2-4 as follows.

\begin{tabular}{|c|c|c|}
\hline Parameter (U-tube steam generator PWR) & Value & Range \\
\hline Thermal power level, MWt & 3800 & $3000-3800$ \\
\hline Steam flow rate, $1 \mathrm{~b} / \mathrm{hr}$ & $17 \times 10^{6}$ & $13 \times 10^{6}-17 \times 10^{6}$ \\
\hline Mass of reactor coolant, $1 \mathrm{~b}$ & $5.5 \times 10^{5}$ & $5.0 \times 10^{5}-6.0 \times 10^{5}$ \\
\hline Water weight in all steam generators, ib & $4.4 \times 10^{5}$ & $4.0 \times 10^{5}-5.0 \times 10^{5}$ \\
\hline Reactor coolant letdown, lb/hr & $4.9 \times 10^{4}$ & $3.2 \times 10^{4}-4.2 \times 10^{4}$ \\
\hline Cation demineralizer flow, $1 \mathrm{~b} / \mathrm{hr}$ & $4.9 \times 10^{3}$ & $0-7.5 \times 10^{3}$ \\
\hline Shim bleed rate - yearly average, $1 \mathrm{~b} / \mathrm{hr}$ & 650 & $250-1000$ \\
\hline Steam generator blowdown flow, lb/hr & 60,000 & $50,000-100,000$ \\
\hline $\begin{array}{l}\text { Fraction of blowdown activity not } \\
\text { returned to secondary system }\end{array}$ & 0.99 & $0.9-1.0$ \\
\hline Cation demineralizer flow, 1b/hr & 4900 & $0.0-7500$ \\
\hline $\begin{array}{l}\text { Condensate demineralizer flow fraction } \\
\text { Y (see definition in Table } 2-4 \text { and } \\
\text { page } 1-26 \text { ) }\end{array}$ & 0.0 & $0.0-0.01$ \\
\hline
\end{tabular}


Since in this example the parameter for reactor coolant letdown rate $\left(4.9 \times 10^{4} \mathrm{lb} / \mathrm{hr}\right)$ is outside the range specified in Table $2-4$ $\left(3.2-4.2 \times 10^{4} \mathrm{lb} / \mathrm{hr}\right)$, and the sample case employs continuous purging of the volume control tank, the primary coolant activity is recalculated using the actual design value for all parameters employing the methods described below.

1. Noble Gases (Xe-133 is used as an example)

Using the equation for noble gases in Table 2-7, the adjustment factor, $f$, is calculated as follows:

$$
f=\frac{162 P}{W P} \frac{0.0009+\lambda}{R+\lambda}
$$

where the terms in the equations are defined in Tables 2-4 and 2-6.

In calculating $f$, the variable $R$ is calculated first by using the equation given in Table 2-6 for noble gases

$$
R=\frac{F B+(F D-F B)(Y)}{W P}
$$

where the terms of the equation are as defined in Tables 2-4 and 2-6.

Use the sample case parameters given above and the noble gas parameters given in Table 2-6 and substitute in Equation (2) above.

$$
R=\frac{650+\left(4.9 \times 10^{4}-650\right) \times 0.25}{5.5 \times 10^{5}}=0.023
$$

Use the value of $R$ in Equation (1) above.

$$
f=\frac{162 \times 3800}{5.5 \times 10^{5}} \frac{0.0009+5.5 \times 10^{-3}}{0.023+5.5 \times 10^{-3}}=0.25
$$

The adjusted $\mathrm{Xe}-133$ primary coolant concentration

$=$ (adjustment factor) $\times$ (standard Xe-133 concentration)

$$
=0.25 \times 2.6 \mu \mathrm{Ci} / \mathrm{g}=0.65 \mu \mathrm{Ci} / \mathrm{g}
$$

2. Halogens (1-131 is used as an example)

Using the equation for halogens in Table 2-7, the adjustment

factor, $f$, is calculated as follows: 


$$
f=\frac{162 P}{W P} \frac{0.067+\lambda}{R+\lambda}
$$

where the terms in the equations are defined in Tables 2-4 and 2-6.

In calculating $f$, the variable $R$ is calculated first by using the equation given in Table 2-6.

$$
R=\frac{(F D)(N B)+(1-N B)(F B+(F A)(N A))}{W P}
$$

where the terms in the equation are as defined in Tables 2-4 and 2-6.

Use the sample case parameters given above and the halogen parameters given in Table 2-6 and substitute in Equation (4) above.

$$
R=\frac{\left(4.9 \times 10^{4} \times 0.99\right)+(1-0.99)(650+(4900)(0.0))}{5.5 \times 10^{5}}=0.088
$$

Use the value of $R$ in Equation (3) above.

$$
f=\frac{162(3800)}{5.5 \times 10^{5}} \quad \frac{0.067+3.6 \times 10^{-3}}{0.088+3.6 \times 10^{-3}}=0.86
$$

The adjusted I-131 concentration

$=$ (adjustment factor) $\times$ (standard I-131 concentration)

$$
=0.86 \times 0.045 \mu \mathrm{Ci} / \mathrm{g}=0.039 \mu \mathrm{Ci} / \mathrm{g}
$$

3. $\mathrm{Cs}, \mathrm{Rb}\left(\mathrm{Cs}_{\mathrm{S}}-137\right.$ is used as an example)

Using the equation for $\mathrm{Cs}$ and $\mathrm{Rb}$ in Table 2-7, the adjustment factor, $f$, is calculated as follows:

$$
f=\frac{162 P}{W P} \frac{0.037+\lambda}{R+\lambda}
$$

where the terms in the equation are as defined in Tables 2-4 and 2-6.

In calculating $f$, the variable $R$ is calculated first by using Equation (4) above. The $\mathrm{Cs}$ and $\mathrm{Rb}$ parameters given in Table 2-6 and the sample case parameters given in Table 2-9 are used in the equation.

$$
R=\frac{\left(4.9 \times 10^{4} \times 0.5\right)+(0.5)(650+(4900)(0.9))}{5.5 \times 10^{5}}=0.05
$$


Use the value of $R$ in Equation (5) above.

$$
f=\frac{162(3800)}{5.5 \times 10^{5}} \frac{0.037+2.6 \times 10^{-6}}{0.05+2.6 \times 10^{-6}}=0.83
$$

The adjusted $\mathrm{Cs}-137$ concentration

$=$ (adjustment factor) $\times$ (standard Cs-137 concentration)

$$
=0.83 \times 9.4 \times 10^{-3} \mu \mathrm{Ci} / \mathrm{g}=7.8 \times 10^{-3} \mu \mathrm{Ci} / \mathrm{g}
$$

4. Other Nuclides (Te-132 is used as an example)

Using the equation for other nuclides in Table 2-7, the adjustment factor, $f$, is calculated as follows:

$$
f=\frac{162 P}{W P} \frac{0.066+\lambda}{R+\lambda}
$$

where the terms in the equation are as defined in Tables 2-4 and 2-6.

In calculating $f$, the variable $R$ is calculated first by using Equation (4) above. The parameters for other nuclides given in Table 2-6 and the sample case parameters given in Table 2-9 are used in the equation.

$$
R=\frac{\left(4.9 \times 10^{4}\right)(0.98)+(1-0.98)(650+(4900)(0.9))}{5.5 \times 10^{5}}=0.087
$$

Use the value of $R$ in equation (6) above.

$$
f=\frac{162(3800)}{5.5 \times 10^{5}} \frac{\left(0.066+8.9 \times 10^{-3}\right)}{0.087+8.9 \times 10^{-3}}=0.87
$$

The adjusted concentration of $\mathrm{Te}-132$

$$
\begin{aligned}
& =\text { (adjustment factor) } \times \text { (standard Te-132 concentration) } \\
& =0.87 \times 1.7 \times 10^{-3} \mu \mathrm{Ci} / \mathrm{g}=1.5 \times 10^{-3} \mu \mathrm{Ci} / \mathrm{g}
\end{aligned}
$$

A similar method is used in the PWR-GALE Code to adjust secondary coolant concentrations for reactors with parameters outside the ranges specified in Tables 2-4 and 2-5.

The radionuclide primary coolant concentrations in Tables 2-2 and 2-3 are based on data submitted by utilities with operating PWR's (Ref. 3). The data are also based on measurements taken by the NRC at Ft. Cainoun (Ref. 4), Zion 1 and 2 (Ref. 5), Turkey Point 3 and 4 (Ref. 6), Rancho Seco (Ref. 43), and Prairie Island 1 and 2 (Ref. 42); by EPRI (Ref. 7) at Three Mile Island 1 and Calvert Cliffs; and by measurements at various other PWR's (Ref. 8, 9, and 39). 
These data are summarized in Table 2-9 and Table 2-10 indicating the average value of the nuclide concentration for each plant, the years over which the data was obtained, and the total number of years of data for each nuclide.

The secondary coolant concentrations are based on the primary coolant concentrations as obtained above, on 75 ib/day primary-to-secondary leakage in the steam generators, on appropriate steam generator carryover factors, on the appropriate main steam flow, steam generator blowdown flow and fraction of a blowdown flow returned to the secondary coolant, as defined in the plant design, and on the fraction of the nuclides in the main steam which return to the steam generators.

The secondary coolant concentrations are based on $751 \mathrm{~b} /$ day primaryto-secondary leakage. The primary-to-secondary leakage rate experience for 79 years of experience at operating PWR's is given in Table 2-11. The average primary-to-secondary leakage rate in Table $2-11$ is $751 \mathrm{~b} /$ day. Westinghouse estimates that the data in Table 2-11 are accurate within $\pm 25 \%(\operatorname{Ref} .8,39)$.

For plants using recirculating U-tube steam generators, carryover due to mechanical entrainment is based on $0.5 \%$ moisture in the steam. Table 2-12 provides measured values for moisture carryover at five operating PWR's that use recirculating U-tube steam generators. Based on data from Turkey Point 3 and 4 (Ref. 6) a value of $1 \%$ iodine carryover with the steam is used in our evaluations. For once-through steam generators, it is assumed that $100 \%$ of both nonvolatile and volatile species is carried over with the steam since this type of steam generator has no liquid reservoir and $100 \%$ of the feed is converted to steam.

For PWR's that use condensate demineralizers in the secondary system, the nominal value of the ratio of the condensate demineralizer flow rate to the total steam flow rate is 0.65 . This indicates that the nominal case is a design which utilizes a pumped forward model, that is, one in which the reactor steam flow is split with $65 \%$ flowing to the low pressure turbines and the main condenser, and $35 \%$ pumped forward to the feedwater. The fraction pumped forward to the feedwater does not undergo any treatment in the condensate demineralizers. We have determined that the iodine, Cs, Rb, and "Other Nuclides" of Table 2-2 and Table 2-3 preferentially go with the "pumped forward" fraction. The reason for this is that these nuclides show a tendency to go with the condensed steam in the moisture separator-reheater drains and with the extraction steam lines from the high pressure turbines to the feedwater system. Based on data provided in Ref. 6,7, 12 and 13 for Turkey Point, Point Beach and Brunswick, the percentages used in the PWR-GALE Code for the amount of activity which is pumped forward and which bypasses the condensate demineralizers is $80 \%$ for iodine and $90 \%$ for $\mathrm{CS}, \mathrm{Rb}$, and "Other Nuclides" of Table 2-2 and Table 2-3. Since the remainder of the nuclides listed in Tables 2-2 and 2-3 are not removed in the condensate demineralizers, we have not considered the magnitude of bypass for those nuclides. 
TABLE 2-9

SUMMARY OF I-131 AND I-133 PRIMARY COOLANT CONCENTRATIONS IN PWR'S*

$(\mu \mathrm{Ci} / \mathrm{g})$

\begin{tabular}{|c|c|c|c|c|c|c|c|}
\hline Is otope & $\begin{array}{l}\text { H.B. Robinson } 2 \\
(1973-1978)^{\star *}\end{array}$ & $\begin{array}{c}\text { Arkansas } 1 \\
(1976) \\
\end{array}$ & $\begin{array}{l}\text { D.C. Cook } 1 \\
(1976-1978)\end{array}$ & $\begin{array}{c}\text { Trojan } \\
(1977-1978) \\
\end{array}$ & $\begin{array}{l}\text { Palisades } \\
(1972-1976) \\
\end{array}$ & $\begin{array}{l}\text { Point Beach 1/2 } \\
\quad(1972-1979) \\
\end{array}$ & $\begin{array}{l}\text { R.E. Ginna } \\
(1971-1978)\end{array}$ \\
\hline $\begin{array}{l}I-131 \\
I-133\end{array}$ & $\begin{array}{l}3.1 E-03 \\
1.2 E-02\end{array}$ & 7. $3 E-03$ & $\begin{array}{r}7.8 \mathrm{E}-03 \\
8 \mathrm{E}-02\end{array}$ & $\begin{array}{l}1.3 \mathrm{E}-02 \\
5 \mathrm{E}-02\end{array}$ & $\begin{array}{l}1.2 \mathrm{E}-02 \\
6 \mathrm{~F}-02\end{array}$ & $\begin{array}{l}7.7 \mathrm{E}-02 \\
3.6 \mathrm{E}-01\end{array}$ & $\begin{array}{l}2.2 \mathrm{E}-01 \\
6.9 \mathrm{E}-01\end{array}$ \\
\hline
\end{tabular}

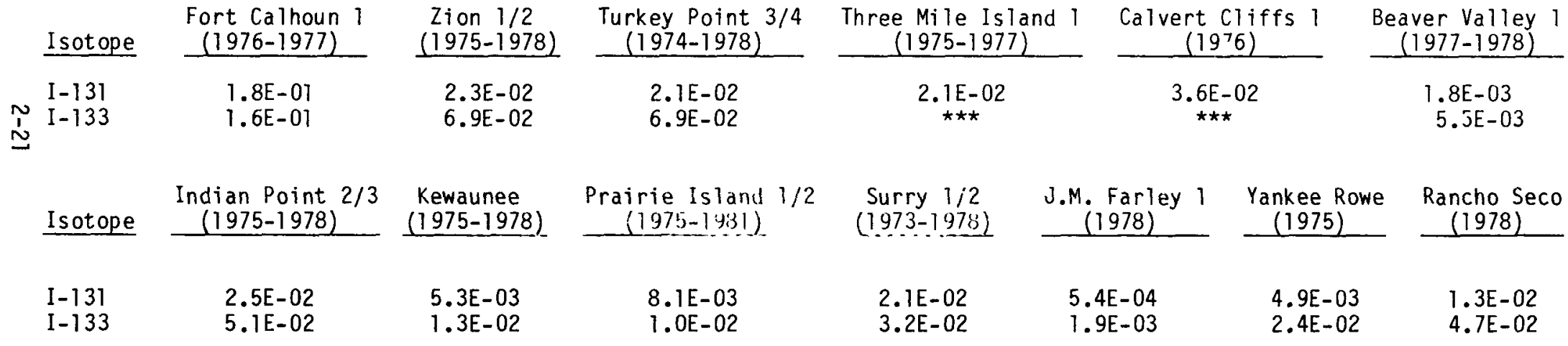

* Data in this table are based on I-131 and I-133 primary coolant concentrations in Ref. 3 through 9 , 42 and 43 , and have been adjusted to the NSS parameters 1 isted in Table 2-4 of this report. These adjustments were made using the individual plant parameters and the nominal plant parameters (Table 2-4) and adjusting the actual coolant concentration using the equations in Table 2-7 of this report.

** Data in this table were gathered during the indicated inclusive dates. It does not necessarily imply that data were available during each of the years covered by the period, nor does it mean that the number of data points should be the same for each radionuclide.

$\star \star \star$ No value reported. 
TABLE 2-10

SUMMARY OF RADIONUCLIDE PRIMARY COOLANT CONCENTRATIONS IN PWR'S* $\left({ }_{\mu \mathrm{C}} / \mathrm{g}\right)$

\begin{tabular}{|c|c|c|c|c|c|c|c|}
\hline Isotope & $\begin{array}{c}\text { H.B. Robinson } 2 \\
(1973-1978)^{\star \star} \\
\end{array}$ & $\begin{array}{c}\text { Arkansas } 1 \\
(1976) \\
\end{array}$ & $\begin{array}{l}\text { D.C. Cook 1 } \\
(1976-1978) \\
\end{array}$ & $\begin{array}{c}\text { Trojan } \\
(1977-1978) \\
\end{array}$ & $\begin{array}{c}\text { Palisades } \\
(1972-1976) \\
\end{array}$ & $\begin{array}{l}\text { Point Beach } 1 / 2 \\
\quad(1972-1979) \\
\end{array}$ & $\begin{array}{l}\text { R.E. Ginna } \\
(1971-1978)\end{array}$ \\
\hline $\begin{array}{l}K r-85 m \\
K r-85\end{array}$ & $\mathfrak{1}_{\star \star \star \star}^{8 \mathrm{E}-02}$ & $\begin{array}{l}8.0 E-03 \\
5.2 E-03\end{array}$ & $\begin{array}{c}3.4 \mathrm{E}-02 \\
\star \star \star\end{array}$ & $\begin{array}{l}2.2 E-02 \\
3.5 E+00\end{array}$ & $\begin{array}{l}4.0 \mathrm{E}-01 \\
8.3 \mathrm{E}-04\end{array}$ & $\begin{array}{l}2.2 E-0 T \\
2.9 E-02\end{array}$ & $\underset{\star \star \star \star \star}{2.4 E-01}$ \\
\hline $\mathrm{Kr}-87$ & $1.7 E-02$ & $6.7 \mathrm{E}-03$ & 4.7E-02 & $4.2 E-02$ & $4.6 \mathrm{E}-01$ & $1.1 \mathrm{E}-01$ & $3.8 \mathrm{E}-01$ \\
\hline $\begin{array}{l}\mathrm{Kr}-88 \\
\mathrm{Xe}-131 \mathrm{n}\end{array}$ & $\begin{array}{c}2.3 \mathrm{E}-02 \\
\star \star \star\end{array}$ & $\begin{array}{c}\text { 1. } 3 \mathrm{E}-02 \\
\star \star \star \star\end{array}$ & $\begin{array}{c}\text { 5. } \\
\star \star \star \star\end{array}$ & $\begin{array}{c}\text { 4. } 0 \mathrm{E}-02 \\
\star \star \star \star\end{array}$ & $\begin{array}{l}7.5 \mathrm{E}-01 \\
4.4 \mathrm{E}+00\end{array}$ & $\begin{array}{l}3.0 \mathrm{E}-01 \\
9.4 \mathrm{E}-01\end{array}$ & $\begin{array}{c}6.3 \mathrm{E}-01 \\
\star \star \star\end{array}$ \\
\hline$x e-133 m$ & $1.6 \mathrm{E}-03$ & 3. $3 E-03$ & $1.5 \mathrm{E}-02$ & $2.7 \mathrm{E}-03$ & $1.9 \mathrm{E}-01$ & $6.5 \mathrm{E}-02$ & $\star \star \star$ \\
\hline$x e-133$ & $2.3 E-01$ & $2.1 \mathrm{E}-01$ & $5.8 E-01$ & $5.7 E-01$ & $4.9 E+00$ & $2.8 E+00$ & 6. $0 \mathrm{E}+00$ \\
\hline$x e-135 m$ & 2. $1 \mathrm{E}-02$ & $\star \star \star$ & 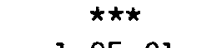 & 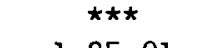 & 1. OE-02 & $1.4 \mathrm{E}-01$ & $1.5 \mathrm{E}-01$ \\
\hline $\begin{array}{l}X e-135 \\
X e-137\end{array}$ & $\begin{array}{c}7.8 E-02 \\
\star \star \star\end{array}$ & $\begin{array}{c}2.7 E-02 \\
\star \star \star\end{array}$ & $\begin{array}{c}1.9 E-01 \\
\star \star \star\end{array}$ & $\begin{array}{c}\text { 1. } 2 \mathrm{E}-01 \\
\star \star \star\end{array}$ & $\begin{array}{l}1.1 E+00 \\
\star \star \star\end{array}$ & $\underbrace{1.1 E+00}_{\star \star \star \star}$ & $\begin{array}{c}2.2 E+00 \\
\star \star \star\end{array}$ \\
\hline $\mathrm{Xe}-138$ & $\star \star \star$ & $\star \star \star$ & $\star \star \star$ & $6.7 \mathrm{E}-02$ & $2.2 E-03$ & $1.7 \mathrm{E}-01$ & $\star \star \star$ \\
\hline $\mathrm{Br}-84$ & $\star \star \star \star$ & $\star \star \star \star$ & 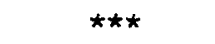 & $\star \star \star \star$ & $\star \star \star \star$ & $\star \star \star \star$ & $\star \star \star$ \\
\hline I -132 & $1.5 E-02$ & $\star \star \star$ & $\star \star \star$ & 1. $9 E-02$ & 7.1E-03 & $3.6 \mathrm{E}-01$ & 7. $3 \mathrm{E}-01$ \\
\hline$I-134$ & $3.2 E-02$ & $\star \star \star$ & $2.4 \mathrm{E}-02$ & $2.2 \mathrm{E}-02$ & $1.0 \mathrm{E}-02$ & $6.2 \mathrm{E}-01$ & $1.2 \mathrm{E}+00$ \\
\hline $1-135$ & $1.9 \mathrm{E}-02$ & $\star \star \star$ & $2.0 E-02$ & $1.7 \mathrm{E}-02$ & $9.2 \mathrm{E}-03$ & $5.7 E-01$ & $6.6 \mathrm{E}-0 \mathrm{~T}$ \\
\hline $\mathrm{Rb}-88$ & $\star \star \star \star$ & $\star \star \star$ & $\star \star \star \star$ & $3.5 \mathrm{E}-02$ & $2.6 \mathrm{E}-02$ & $1.7 \bar{E}-01$ & $3.7 \mathrm{E}-01$ \\
\hline $\begin{array}{l}\mathrm{Cs}-134 \\
\mathrm{Cs}-136\end{array}$ & $\begin{array}{l}\text { 1. } 9 \mathrm{E}-03 \\
\text { 3. } 1 \mathrm{E}-04\end{array}$ & $\begin{array}{c}5.6 \mathrm{E}-04 \\
\star \star \star\end{array}$ & $\begin{array}{l}2.7 E-03 \\
5.2 E-03\end{array}$ & $\begin{array}{l}6.0 \mathrm{E}-04 \\
7.2 \mathrm{E}-04\end{array}$ & $\begin{array}{l}\text { 1. } 7 \mathrm{E}-04 \\
4.6 \mathrm{E}-05\end{array}$ & $\begin{array}{l}1.4 E-02 \\
2.2 E-03\end{array}$ & 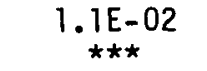 \\
\hline $\begin{array}{l}\mathrm{Cs}-137 \\
\mathrm{~N}-16\end{array}$ & $\begin{array}{c}2.3 E-03 \\
\star \star \star\end{array}$ & $\begin{array}{c}1.5 E-03 \\
\star \star \star\end{array}$ & $\begin{array}{c}\text { 4. } 9 E-03 \\
\star \star \star\end{array}$ & $\underbrace{1.3 \mathrm{E}-03}_{\star \star \star \star}$ & $\begin{array}{c}2.6 \mathrm{E}-04 \\
\star \star \star\end{array}$ & $\underset{\star 1 . \star 1 E}{1.02}$ & $\underset{\star \star \star \star \star}{3.1 E-02}$ \\
\hline $\mathrm{H}-3$ & $\star \star \star$ & $6.3 \mathrm{E}-02$ & $2.1 E-01$ & $\star \star \star$ & $7.5 \mathrm{E}-02$ & $5.0 E-01$ & 6.7E-01 \\
\hline $\mathrm{Na}-24$ & $1.3 E-01$ & $8.7 E-02$ & 1. $2 \mathrm{E}-02$ & 1. $3 \mathrm{E}-02$ & $5.6 \mathrm{E}-03$ & 7. $6 \mathrm{E}-02$ & 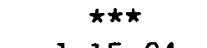 \\
\hline $\mathrm{Cr}-51$ & $3.5 E-04$ & $3.2 E-03$ & $\star \star \star$ & $\star \star \star$ & $9.1 E-03$ & $\star \star \star$ & $1.1 E-04$ \\
\hline$M n-54$ & $3.4 E-04$ & 7. $6 \mathrm{E}-04$ & $8.3 E-03$ & $9.7 \mathrm{E}-04$ & $1.1 E-04$ & 2. $8 \mathrm{E}-03$ & $2.5 E-05$ \\
\hline $\mathrm{Fe}-55$ & $\star \star \star \star$ & $\star \star \star$ & $\star \star \star$ & $\star \star \star$ & $\star \star \star$ & $\star \star \star$ & $\star \star \star$ \\
\hline $\mathrm{Fe}-59$ & $1.4 E-05$ & $1.6 \mathrm{E}-03$ & $\star \star \star$ & $\star \star \star$ & $1.6 \mathrm{E}-04$ & $\star \star \star$ & 2. $6 \mathrm{E}-05$ \\
\hline $\mathrm{Co}-58$ & 1. $3 \mathrm{E}-03$ & 7.0E-03 & $1.4 \mathrm{E}-02$ & 2. $2 \mathrm{E}-03$ & $3.4 E-03$ & $9.6 \mathrm{E}-03$ & $7.6 \mathrm{E}-04$ \\
\hline $\mathrm{Co}-60$ & $3.5 \mathrm{E}-04$ & $6.4 E-04$ & $4.5 E-03$ & $3.4 E-05$ & $1.1 E-04$ & $2.3 E-04$ & $1.6 E-04$ \\
\hline$Z n-65$ & $1.7 \mathrm{E}-05$ & $\star \star \star$ & $\star \star \star$ & 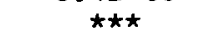 & $7.0 \mathrm{E}-05$ & $\star \star \star$ & $\star \star \star$ \\
\hline $\mathrm{Sr}-89$ & $2.3 \mathrm{E}-05$ & $\star \star \star \star$ & $\star \star \star$ & $\star \star \star$ & $\star \star \star$ & $2.4 E-04$ & $\star \star \star$ \\
\hline$S r-90$ & $5.2 E-06$ & $\star \star \star$ & $\star \star \star$ & $\star \star \star$ & 1. $1 E-04$ & $\star \star \star \star$ & $\star \star \star$ \\
\hline
\end{tabular}


TABLE 2-10 (continued)

SUMMARY OF RADIONUCLIDE PRIMARY COOLANT CONCENTRATIONS IN PWR' $S^{\star}$ $\left({ }_{\mu} \mathrm{Ci} / \mathrm{g}\right)$

\begin{tabular}{|c|c|c|c|c|c|c|c|}
\hline Isotope & $\begin{array}{l}\text { H.B. Robinson } 2 \\
(1973-1978)^{\star \star} \\
\end{array}$ & $\begin{array}{c}\text { Arkansas } 1 \\
(1976) \\
\end{array}$ & $\begin{array}{l}\text { D.C. Cook } 1 \\
(1976-1978) \\
\end{array}$ & $\begin{array}{c}\text { Trojan } \\
(1977-1978) \\
\end{array}$ & $\begin{array}{c}\text { Palisades } \\
(1972-1976) \\
\end{array}$ & $\begin{array}{c}\text { Point Beach 1/2 } \\
(1972-1979) \\
\end{array}$ & $\begin{array}{l}\text { R.E. Ginna } \\
(1971-1978) \\
\end{array}$ \\
\hline$S r-91$ & $4.9 E-04$ & $\star \star \star$ & $\star \star \star$ & $\star \star \star$ & $1.1 E-04$ & $\star \star \star$ & $\star \star \star$ \\
\hline$Y-91 m$ & $\star \star \star$ & $\star \star \star$ & $\star \star \star$ & $\star \star \star$ & $\star \star \star$ & $\star \star \star$ & $\star \star \star$ \\
\hline$Y-91$ & $\star \star \star$ & $\star \star \star$ & $\star \star \star$ & $\star \star \star$ & $\star \star \star$ & $\star \star \star$ & $\star \star \star$ \\
\hline$Y-93$ & $\star \star \star$ & $\star \star \star$ & $\star \star \star$ & $\star \star \star$ & $\star \star \star$ & $\star \star \star$ & $\star \star \star$ \\
\hline Zr-95 & $1.3 E-05$ & $3.4 E-04$ & $4.5 E-03$ & $\star \star \star$ & $1.0 \mathrm{E}-04$ & $\star \star \star$ & $1.5 \mathrm{E}-03$ \\
\hline $\mathrm{Nb}-95$ & 1. $3 E-05$ & $3.1 E-04$ & $2.4 \mathrm{E}-03$ & $\star \star \star$ & $7.6 \mathrm{E}-05$ & $3.6 E-04$ & $8.1 E-05$ \\
\hline Mo-99 & $\star \star \star$ & $7.2 E-05$ & $\star \star \star \star$ & $\star \star \star$ & $5.7 E-04$ & $3.8 \mathrm{E}-02$ & $4.1 E-04$ \\
\hline Tc-99m & $\star \star \star \star$ & $\star \star \star$ & $\star \star \star$ & $\star \star \star$ & $7.3 \mathrm{E}-04$ & $2.5 E-02$ & $\star \star \star$ \\
\hline$R u-103$ & $\star \star \star$ & $\star \star \star$ & $\star \star \star$ & $\star \star \star$ & $\star \star \star$ & $\star \star \star$ & 1. $2 \mathrm{E}-03$ \\
\hline Ru- 106 & $\star \star \star$ & $\star \star \star$ & $\star \star \star \star$ & $\star \star \star$ & $\star \star \star$ & $\star \star \star$ & $\star \star \star$ \\
\hline $\mathrm{Ag}-110 \mathrm{~m}$ & $\star \star \star$ & $\star \star \star$ & $\star \star \star$ & $\star \star \star$ & $\star \star \star$ & $8.8 E-03$ & $\star \star \star$ \\
\hline $\mathrm{Te}-129 \mathrm{~m}$ & $\star \star \star$ & $\star \star \star$ & $\star \star \star$ & $\star \star \star$ & $\star \star \star$ & $\star \star \star$ & $\star \star \star$ \\
\hline Le-129 & $\star \star \star$ & $\star \star \star$ & $\star \star \star$ & $\star \star \star$ & $\star \star \star$ & $\star \star \star$ & $\star \star \star$ \\
\hline Te-131m & $\star \star \star$ & $\star \star \star$ & $\star \star \star$ & $\star \star \star$ & $\star \star \star$ & $\star \star \star$ & $\star \star \star$ \\
\hline Te-131 & $\star \star \star$ & $\star \star \star$ & $\star \star \star \star *$ & $\star \star \star$ & $\star \star \star$ & $\star \star \star$ & $\star \star \star$ \\
\hline $\mathrm{Te}-132$ & $\star \star \star$ & $1.3 \mathrm{E}-03$ & $\star \star \star$ & $\star \star \star$ & $6.6 E-05$ & $8.8 E-03$ & $\star \star \star$ \\
\hline $\mathrm{Ba}-140$ & $2.0 \mathrm{E}-04$ & $\star \star \star$ & $\star \star \star$ & $\star \star \star$ & $6.2 \mathrm{E}-06$ & $1.6 \mathrm{E}-01$ & $5.9 E-05$ \\
\hline $\mathrm{La}-140$ & $9.2 E-05$ & $\star \star \star$ & $\star \star \star$ & $\star \star \star$ & $3.0 E-05$ & $5.2 E-01$ & $\star \star \star$ \\
\hline $\mathrm{Ce}-141$ & $\star \star \star$ & $\star \star \star$ & $\star \star \star$ & $\star \star \star$ & $\star \star \star$ & $\star \star \star$ & $\star \star \star$ \\
\hline $\mathrm{Ce}-143$ & $\star \star \star$ & $\star \star \star$ & $\star \star \star$ & $\star \star \star$ & $\star \star \star$ & $\star \star \star$ & $\star \star \star$ \\
\hline $\mathrm{Ce}-144$ & $2.6 \mathrm{E}-04$ & $1.4 \mathrm{E}-03$ & $\star \star \star$ & $\star \star \star$ & $\star \star \star$ & $4.5 \mathrm{E}-02$ & $\star \star \star$ \\
\hline$W-187$ & $3.4 \mathrm{E}-04$ & $\star \star \star$ & $\star \star \star$ & $\star \star \star$ & $5.8 E-04$ & $\star \star \star$ & $\star \star \star$ \\
\hline$N p-239$ & $\star \star \star$ & $\star \star \star$ & $\star \star \star$ & $\star \star \star$ & $\star \star \star$ & $\star \star \star$ & 2. $0 \mathrm{E}-03$ \\
\hline
\end{tabular}


TABLE 2-10 (continued)

SUMMARY OF RADIONUCLIDE PRIMARY COOLANT CONCENTRATIONS IN PWR' $S *$

$$
(\mu \mathrm{Ci} / \mathrm{g})
$$

\begin{tabular}{|c|c|c|c|c|c|c|c|c|c|}
\hline Isotope & $\begin{array}{c}\text { Fort } \\
\text { Calhoun } 1 \\
\langle 1976-1977\rangle\end{array}$ & $\begin{array}{c}\text { Zion } 1 / 2 \\
(1975-1978) \\
\end{array}$ & $\begin{array}{c}\text { Turkey } \\
\text { Point } 3 / 4 \\
(1974-1978) \\
\end{array}$ & $\begin{array}{c}\text { Indian } \\
\mathrm{Pt} 2 / 3 \\
(1975-1978) \\
\end{array}$ & $\begin{array}{c}\text { Yankee } \\
\text { Rowe } \\
(1975) \\
\end{array}$ & $\begin{array}{l}\text { Caivert } \\
\text { Cliffs } 1 \\
(1976) \\
\end{array}$ & $\begin{array}{c}\text { Three Mile } \\
\text { Is land } 1 \\
(1975-1977) \\
\end{array}$ & $\begin{array}{l}\text { Prairie } \\
\text { Island } 1 / 2 \\
(1981) \\
\end{array}$ & $\begin{array}{c}\text { Rancho } \\
\text { Seco } \\
(1979)\end{array}$ \\
\hline $\mathrm{Kr}-85 \mathrm{~m}$ & $1.9 \mathrm{E}-01$ & $\star \star \star$ & $7.8 \mathrm{E}-02$ & $3.4 E-02$ & $5.7 \mathrm{E}-03$ & $\star \star \star \star$ & $\star \star \star$ & $4.9 \mathrm{E}-04$ & $5.5 E-02$ \\
\hline $\mathrm{Kr}-85$ & $3.4 E-02$ & $\star \star \star$ & $\star \star \star$ & $\star \star \star \star$ & $\star \star \star$ & $\star \star \star$ & $\star \star \star$ & 3. $3 \mathrm{E}-04$ & 2.2E-01 \\
\hline$k r-87$ & 1. $9 E-01$ & $\star \star \star$ & $9.0 \mathrm{E}-02$ & $\star \star \star$ & $7.6 E-03$ & $\star \star \star$ & $\star \star \star$ & $1.1 \mathrm{E}-03$ & $5.9 E-02$ \\
\hline $\mathrm{Kr}-88$ & $3.2 E-01$ & $\star \star \star \star$ & $1.3 \mathrm{E}-01$ & 7. $3 E-02$ & 1. $9 \mathrm{E}-02$ & $\star \star \star \star$ & $\star \star \star$ & $1.1 E-03$ & $9.9 E-02$ \\
\hline $\mathrm{Xe}-131 \mathrm{~m}$ & $6.8 E-02$ & $\star \star \star$ & $1.2 \mathrm{E}-03$ & $\star \star \star \star$ & $\star \star \star$ & $\star \star \star$ & $\star \star \star$ & $4.2 E-05$ & $3.5 E-03$ \\
\hline $\mathrm{Xe}-133 \mathrm{~m}$ & $1.6 E-01$ & $\star \star \star$ & $9.1 E-03$ & $\star \star \star$ & $\star \star \star \star$ & $\star \star \star$ & $\star \star \star$ & $7.2 \mathrm{E}-05$ & $4.5 E-02$ \\
\hline$X e-133$ & $6.7 E+00$ & $\star \star \star$ & $8.8 \mathrm{E}-01$ & $8.3 E-01$ & $2.1 E-01$ & $\star \star \star$ & $\star \star \star$ & $2.2 E-03$ & $1.5 E+00$ \\
\hline$x e-135 m$ & $9.5 E-02$ & $\star \star \star$ & $1.7 E-01$ & $1.0 \mathrm{E}-01$ & $\star \star \star \star A$ & $\star \star \star$ & $\star \star \star$ & $1.4 \mathrm{E}-03$ & $6.0 E-01$ \\
\hline$x e-135$ & $9.3 \mathrm{E}-01$ & $\star \star \star$ & $5.1 E-01$ & $1.9 E-01$ & $3.0 E-02$ & $\star \star \star \star$ & $\star \star \star$ & $3.6 \mathrm{E}-03$ & $4.6 E-01$ \\
\hline $\mathrm{Xe}-137$ & $\star \star \star \star$ & $\star \star \star$ & $3.4 \mathrm{E}-02$ & $\star \star \star \star$ & $\star \star \star$ & $\star \star \star$ & $\star \star \star$ & 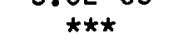 & $\star \star \star \dagger$ \\
\hline$X e-138$ & $1.8 \mathrm{E}-01$ & $\star \star \star$ & $7.6 E-02$ & $\star \star \star$ & $\star \star \star$ & $\star \star \star$ & $\star \star \star$ & $2.9 \mathrm{E}-03$ & $1.7 \mathrm{E}-01$ \\
\hline $\mathrm{Br}-84$ & $\star \star \star$ & $\star \star \star$ & $1.1 E-02$ & $\star \star \star$ & $\star \star \star$ & $\star \star \star$ & $\star \star \star$ & $1.0 \mathrm{E}-03$ & $5.5 E-02$ \\
\hline I -132 & $7.1 E-02$ & $9.6 E-02$ & $9.3 \mathrm{E}-02$ & $\star \star \star$ & $1.8 E-02$ & $\star \star \star$ & 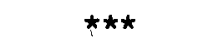 & $5.1 E-03$ & 5. $3 E-02$ \\
\hline$I-134$ & $3.8 \mathrm{E}-02$ & $1.3 \mathrm{E}-01$ & $1.5 E-01$ & $\star \star \star$ & $\star \star \star \star$ & $\star \star \star$ & $\star \star \star$ & $9.0 \mathrm{E}-03$ & $8.3 \mathrm{E}-02$ \\
\hline$I-135$ & $7.4 E-02$ & $1.1 E-01$ & $8.6 \mathrm{E}-02$ & $\star \star \star *$ & $\star \star \star$ & $\star \star \star$ & $\star \star \star$ & $5.8 E-03$ & $6.0 \mathrm{E}-02$ \\
\hline$R b-88$ & $5.0 E-01$ & $2.3 E-01$ & $1.0 \mathrm{E}-01$ & $\star \star \star$ & $\star \star \star$ & $\star \star \star$ & $\star \star \star$ & $5.7 \mathrm{E}-03$ & $1.5 \mathrm{E}-01$ \\
\hline Cs-134 & $1.8 \mathrm{E}-02$ & $9.4 E-03$ & $1.8 \mathrm{E}-03$ & $1.9 \mathrm{E}-02$ & $\star \star \star$ & $\star \star \star$ & $\star \star \star$ & $2.2 E-05$ & $7.7 \mathrm{E}-03$ \\
\hline$C_{5}-136$ & $1.7 E-03$ & $1.2 E-03$ & $1.1 E-04$ & $\star \star \star \star$ & $\star \star \star$ & $\star \star \star$ & $\star \star \star$ & 3. $2 E-06$ & 1.9E-04 \\
\hline Cs-137 & $2.0 \mathrm{E}-02$ & $1.2 E-02$ & $3.1 E-03$ & $2.4 \mathrm{E}-02$ & $\star \star \star$ & $\star \star \star$ & $\star \star \star$ & $6.7 \mathrm{E}-05$ & $9.4 E-03$ \\
\hline$N-16$ & $\star \star \star$ & $\star \star \star$ & $\star \star \star$ & $\star \star \star$ & $\star \star \star$ & $\star \star \star$ & $\star \star \star$ & $\star \star \star$ & $\star \star \star$ \\
\hline $\mathrm{H}-3$ & $1.3 E-01$ & $1.5 E-01$ & $\star \star \star$ & $\star \star \star$ & $\star \star \star$ & $4.4 E-02$ & $1.2 \mathrm{E}-01$ & $2.9 \mathrm{E}-01$ & $2.5 E-01$ \\
\hline $\mathrm{Na}-24$ & $8.8 E-03$ & $1.0 E-01$ & $1.0 \mathrm{E}-02$ & $3.6 \mathrm{E}-03$ & $\star \star \star$ & $\star \star \star *$ & $\star \star \star$ & $9.0 \mathrm{E}-03$ & $1.4 \mathrm{E}-02$ \\
\hline$C r-51$ & $1.5 \mathrm{E}-02$ & 2.1E-03 & $3.4 E-04$ & $\star \star \star \star$ & $1.7 E-03$ & $\star \star \star$ & $\star \star \star$ & $3.0 \mathrm{E}-05$ & $6.4 E-03$ \\
\hline$M n-54$ & $4.4 \mathrm{E}-03$ & $2.2 E-03$ & $3.9 E-05$ & $1.5 E-02$ & $1.1 \mathrm{E}-04$ & $\star \star \star$ & $\star \star \star$ & $1.0 \mathrm{E}-05$ & $6.8 E-04$ \\
\hline $\mathrm{Fe}-55$ & $6.5 \mathrm{E}-04$ & $1.6 \mathrm{E}-04$ & $\star \star \star$ & $\star \star \star \star$ & $\star \star \star \star$ & $\star \star \star \star$ & $\star \star \star$ & 2. $3 \mathrm{E}-05$ & $9.1 \mathrm{E}-03$ \\
\hline $\mathrm{Fe}-59$ & $5.2 E-04$ & $6.2 E-04$ & $2.3 E-04$ & $\star \star \star$ & $6.9 E-04$ & $\star \star \star$ & $\star \star \star$ & $1.5 \mathrm{E}-06$ & $5.2 E-04$ \\
\hline Co-58 & $1.4 \mathrm{E}-02$ & $4.6 \mathrm{E}-03$ & $6.7 \mathrm{E}-04$ & $3.6 \mathrm{E}-03$ & $5.8 E-04$ & $\star \star \star$ & $\star \star \star$ & $8.0 \mathrm{E}-05$ & $2.4 E-02$ \\
\hline Co- 60 & $1.0 \mathrm{E}-03$ & $7.8 E-04$ & $1.2 E-04$ & $3.1 E-03$ & $4.7 E-04$ & $\star \star \star$ & $\star \star \star$ & $1.6 E-05$ & $9.2 \mathrm{E}-04$ \\
\hline$Z n-65$ & $2.6 \mathrm{E}-03$ & $2.4 E-03$ & $1.6 \mathrm{E}-05$ & $\star \star \star$ & 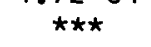 & $\star \star \star$ & $\star \star \star$ & $1.7 \mathrm{E}-06$ & $2.2 E-05$ \\
\hline$S r-89$ & $6.8 \mathrm{E}-04$ & $7.7 E-05$ & $6.8 E-07$ & $\star \star \star$ & $\star \star \star$ & $\star \star \star$ & $\star \star \star$ & $6.6 \mathrm{E}-06$ & $\star \star \star$ \\
\hline $\mathrm{Sr}-90$ & $4.2 E-06$ & $3.4 E-06$ & $1.6 \mathrm{E}-06$ & $\star \star \star \star$ & $\star \star \star$ & $\star \star \star \star$ & $\star \star \star$ & $5.4 \mathrm{E}-08$ & $\star \star \star$ \\
\hline
\end{tabular}


TABLE 2-10 (continued)

SUMMARY OF RADIONUCLIDE PRIMARY COOLANT CONCENTRATIONS IN PWR' $S^{\star}$

\begin{tabular}{|c|c|c|c|c|c|c|c|c|c|}
\hline Isotope & $\begin{array}{c}\text { Fort } \\
\text { Calhoun } 1 \\
(1976-1977) \\
\end{array}$ & $\begin{array}{c}\text { Zion } 1 / 2 \\
(1975-1978) \\
\end{array}$ & $\begin{array}{c}\text { Turkey } \\
\text { Point 3/4 } \\
\text { (1974-1978) } \\
\end{array}$ & $\begin{array}{c}\text { Indian } \\
\text { Pt } 2 / 3 \\
(1975-1978) \\
\end{array}$ & $\begin{array}{c}\text { Yankee } \\
\text { Rowe } \\
(1975) \\
\end{array}$ & $\begin{array}{l}\text { Calvert } \\
\text { Cliffs I } \\
(1976) \\
\end{array}$ & $\begin{array}{l}\text { Three Mile } \\
\text { Island 1 } \\
(1975-1977)\end{array}$ & $\begin{array}{c}\text { Prairie } \\
\text { Is land } 1 / 2 \\
(1981) \\
\end{array}$ & $\begin{array}{c}\text { Rancho } \\
\text { Seco } \\
(1979) \\
\end{array}$ \\
\hline $\begin{array}{l}\mathrm{Sr}-91 \\
\mathrm{Y}-91 \mathrm{~m} \\
\mathrm{Y}-91 \\
\mathrm{Y}-93 \\
\mathrm{Zr}-95 \\
\mathrm{Nb}-95 \\
\mathrm{Mo}-99 \\
\mathrm{Tc}-99 \mathrm{~m} \\
\mathrm{Ru}-103 \\
\mathrm{Ru}-106 \\
\mathrm{Ag}-11 \mathrm{~m} \\
\mathrm{Te}-129 \mathrm{~m} \\
\mathrm{Te}-129 \\
\mathrm{Te}-131 \mathrm{~m} \\
\mathrm{Te}-131 \\
\mathrm{Te}-132 \\
\mathrm{Ba}-140 \\
\mathrm{La}-140 \\
\mathrm{Ce}-141 \\
\mathrm{Ce}-143 \\
\mathrm{Ce}-144 \\
\mathrm{~W}-187 \\
\mathrm{~Np}-239\end{array}$ & $\begin{array}{c}\star \star \star \\
\star \star \star \\
5.0 \mathrm{E}-06 \\
\star \star \star \\
1.5 \mathrm{E}-03 \\
1.3 \mathrm{E}-03 \\
5.7 \mathrm{E}-03 \\
4.1 \mathrm{E}-04 \\
5.4 \mathrm{E}-02 \\
\star \star \star \\
2.2 \mathrm{E}-04 \\
2.1 \mathrm{E}-04 \\
\star \star \star \\
\star \star \star \\
\star \star \star \\
\star \star \star \\
1.1 \mathrm{E}-03 \\
4.2 \mathrm{E}-04 \\
4.3 \mathrm{E}-04 \\
8.2 \mathrm{E}-03 \\
\star \star \star \\
1.4 \mathrm{E}-02 \\
1.2 \mathrm{E}-02\end{array}$ & $\begin{array}{l}3.8 \mathrm{E}-03 \\
8.7 \mathrm{E}-04 \\
4.4 \mathrm{E}-06 \\
7.9 \mathrm{E}-03 \\
4.2 \mathrm{E}-04 \\
2.2 \mathrm{E}-04 \\
3.5 \mathrm{E}-03 \\
\star \star \star \\
1.8 \mathrm{E}-04 \\
9.0 \mathrm{E}-02 \\
3.1 \mathrm{E}-03 \\
3.8 \mathrm{E}-04 \\
\star \star \star \\
2.1 \mathrm{E}-03 \\
\star \star \star \\
1.8 \mathrm{E}-04 \\
1.0 \mathrm{E}-03 \\
1.8 \mathrm{E}-03 \\
1.1 \mathrm{E}-04 \\
4.6 \mathrm{E}-04 \\
1.4 \mathrm{E}-04 \\
3.1 \mathrm{E}-03 \\
9.3 \mathrm{E}-04\end{array}$ & $\begin{array}{c}3.7 \mathrm{E}-04 \\
\star \star \star \\
\star \star \star \\
2.2 \mathrm{E}-03 \\
4.5 \mathrm{E}-05 \\
3.8 \mathrm{E}-05 \\
8.1 \mathrm{E}-04 \\
2.7 \mathrm{E}-06 \\
2.1 \mathrm{E}-05 \\
\star \star \star \\
1.1 \mathrm{E}-05 \\
1.9 \mathrm{E}-04 \\
2.4 \mathrm{E}-02 \\
3.7 \mathrm{E}-04 \\
7.9 \mathrm{E}-03 \\
4.0 \mathrm{E}-05 \\
1.1 \mathrm{E}-04 \\
1.3 \mathrm{E}-04 \\
1.7 \mathrm{E}-05 \\
4.9 \mathrm{E}-05 \\
1.2 \mathrm{E}-05 \\
3.0 \mathrm{E}-04 \\
1.0 \mathrm{E}-04\end{array}$ & $\begin{array}{l}\star \star \star \\
\star \star \star \\
\star \star \star \\
\star \star \star \\
\star \star \star \\
\star \star \star \\
\star \star \star \\
\star \star \star \\
\star \star \star \\
\star \star \star \\
\star \star \star \\
\star \star \star \\
\star \star \star \\
\star \star \star \\
\star \star \star \\
\star \star \star \\
\star \star \star \\
\star \star \star \\
\star \star \star \\
\star \star \star \\
\star \star \star \\
\star \star \star \\
\star \star \star\end{array}$ & $\begin{array}{c}\star \star \star \\
\star \star \star \\
\star \star \star \\
\star \star \star \\
2.8 \mathrm{E}-04 \\
2.4 \mathrm{E}-04 \\
5.0 \mathrm{E}-03 \\
4.9 \mathrm{E}-03 \\
\star \star \star \\
\star \star \star \\
\star \star \star \\
\star \star \star \\
\star \star \star \\
\star \star \star \\
\star \star \star \\
\star \star \star \\
\star \star \star \\
\star \star \star \\
\star \star \star \\
\star \star \star \\
2.6 \mathrm{E}-05 \\
\star \star \star \\
\star \star \star\end{array}$ & $\begin{array}{l}\star \star \star \\
\star \star \star \\
\star \star \star \\
\star \star \star \\
\star \star \star \\
\star \star \star \\
\star \star \star \\
\star \star \star \\
\star \star \star \\
\star \star \star \\
\star \star \star \\
\star \star \star \\
\star \star \star \\
\star \star \star \\
\star \star \star \\
\star \star \star \\
\star \star \star \\
\star \star \star \\
\star \star \star \\
\star \star \star \\
\star \star \star \\
\star \star \star \\
\star \star \star\end{array}$ & $\begin{array}{l}\star \star \star \\
\star \star \star \\
\star \star \star \\
\star \star \star \\
\star \star \star \\
\star \star \star \\
\star \star \star \\
\star \star \star \\
\star \star \star \\
\star \star \star \\
\star \star \star \\
\star \star \star \\
\star \star \star \\
\star \star \star \\
\star \star \star \\
\star \star \star \\
\star \star \star \\
\star \star \star \\
\star \star \star \\
\star \star \star \\
\star \star \star \\
\star \star \star \\
\star \star \star\end{array}$ & $\begin{array}{c}3.3 \mathrm{E}-05 \\
5.0 \mathrm{E}-05 \\
4.3 \mathrm{E}-07 \\
2.1 \mathrm{E}-04 \\
4.6 \mathrm{E}-06 \\
3.9 \mathrm{E}-06 \\
1.3 \mathrm{E}-04 \\
\star \star \star \\
6.7 \mathrm{E}-07 \\
\star \star \star \\
3.7 \mathrm{E}-06 \\
2.0 \mathrm{E}-06 \\
\star \star \star \\
\star \star \star \\
\star \star \star \\
1.2 \mathrm{E}-06 \\
1.9 \mathrm{E}-05 \\
1.4 \mathrm{E}-05 \\
\star \star \star \\
1.9 \mathrm{E}-05 \\
5.4 \mathrm{E}-06 \\
1.1 \mathrm{E}-04 \\
3.7 \mathrm{E}-06\end{array}$ & $\begin{array}{c}7.2 \mathrm{E}-04 \\
\star \star \star \\
1.8 \mathrm{E}-05 \\
2.6 \mathrm{E}-03 \\
2.9 \mathrm{E}-04 \\
4.6 \mathrm{E}-04 \\
1.7 \mathrm{E}-03 \\
\star \star \star \\
7.0 \mathrm{E}-05 \\
\star \star \star \\
9.7 \mathrm{E}-05 \\
\star \star \star \\
\star \star \star \\
\star \star \star \\
7.4 \mathrm{E}-03 \\
3.1 \mathrm{E}-05 \\
2.5 \mathrm{E}-04 \\
1.1 \mathrm{E}-04 \\
4.6 \mathrm{E}-05 \\
\star \star \star \\
4.6 \mathrm{E}-04 \\
2.9 \mathrm{E}-03 \\
7.6 \mathrm{E}-04\end{array}$ \\
\hline
\end{tabular}

* See Footnote of Table 2-9.

** See Footnote of Table 2-9.

$\star \star \star$ See Footnote of Table 2-9.

$\dagger$ Data unreliable. 
TABLE 2-11

MONTHLY AVERAGE* PRIMARY/SECONDARY LEAKAGE (REF. 8, 39)

(gal/day at $70^{\circ} \mathrm{F}$; density $=8.31 \mathrm{~b} / \mathrm{gal}$ )

$\underline{1970}$

\begin{tabular}{lllllllllllll}
\multicolumn{1}{c}{ Plant } & $\mathrm{J}$ & $\mathrm{F}$ & $\mathrm{M}$ & $\mathrm{A}$ & $\mathrm{M}$ & $\mathrm{J}$ & $\mathrm{J}$ & $\mathrm{A}$ & $\mathrm{S}$ & 0 & $\mathrm{~N}$ & $\mathrm{D}$ \\
\cline { 3 - 5 } Sanofre & 4 & 4 & 4 & 4 & 3 & 9 & 11 & 8 & 14 & $\mathrm{~S}^{*}$ & $\mathrm{~S}$ & 0 \\
Connecticut & 0 & 10 & 0 & $\mathrm{~S}$ & 0 & 0 & 20 & 10 & 20 & 0 & 0 & 0
\end{tabular}

Yankee

R. E. Ginna

Point Beach 1

$\begin{array}{llllll}0 & 0 & 0 & 0 & 0 & 0\end{array}$

Plant

San Onofre

Connecticut Yankee

R. E. Ginna

H. B. Robinson

Point Beach 1

\begin{tabular}{cccccccccccc}
$J$ & $F$ & $M$ & $A$ & $M$ & $J$ & $J$ & $A$ & $S$ & 0 & $N$ & $D$ \\
\hline 0 & 0 & 0 & 0 & 0 & 0 & 0 & 0 & 0 & 0 & 0 & 0
\end{tabular}

$\begin{array}{llllllllllll}0 & 30 & 15 & 0 & 0 & 10 & 20 & 20 & 15 & 40 & 40 & 40\end{array}$

$\begin{array}{llllllllllll}0 & 0 & \mathrm{~S} & \mathrm{~S} & 0 & 0 & 0 & 0 & 0 & 0 & 0 & 0\end{array}$

$\begin{array}{llllllllllll} & & \mathrm{S} & \mathrm{S} & \mathrm{S} & \mathrm{S} & \mathrm{S} & \mathrm{S} & 0 & 50 & 55 & 20 \\ 0 & 0 & 0 & 10 & 90 & 100 & 53 & 30 & 20 & 20 & 20 & 20\end{array}$

$\underline{1972}$

Plant
San Onofre
Connecticut
Yankee

R. E. Ginna

H. B. Robinson

Point Beach 1

Point Beach 2

Surry 1

Turkey Point 3

\begin{tabular}{llllllllllll}
$\mathrm{J}$ & $\mathrm{F}$ & $\mathrm{M}$ & $\mathrm{A}$ & $\mathrm{M}$ & $\mathrm{J}$ & $\mathrm{J}$ & $\mathrm{A}$ & $\mathrm{S}$ & 0 & $\mathrm{~N}$ & $\mathrm{D}$ \\
\hline $\mathrm{S}$ & 0 & 0 & 0 & 0 & 0 & 22 & 0 & 10 & 30 & 4 & 31 \\
40 & 40 & 40 & 40 & 40 & $\mathrm{~S}$ & 0 & 0 & 0 & 0 & 0 & 0
\end{tabular}

$\begin{array}{llllllllllll}0 & 0 & 0 & \mathrm{~S} & \mathrm{~S} & 0 & 0 & 0 & 0 & \mathrm{~S} & 0 & 0\end{array}$

$\begin{array}{llllllllllll}60 & 60 & 60 & 60 & 3 & 0 & 0 & 0 & 0 & 0 & 0 & 0\end{array}$

$\begin{array}{llllllllllll}40 & 50 & 55 & 55 & 55 & 55 & 55 & 55 & 55 & \mathrm{~S} & \mathrm{~S} & \mathrm{~S}\end{array}$

$0 \quad 0 \quad 0$

* Leakage values listed begin with the first year of commercial operation.

** Shutdown not included in average.

NA - Not Available. 
TABLE 2-11 (continued)

MONTHLY AVERAGE* PRIMARY/SECONDARY LEAKAGE

(gal/day at $70^{\circ} \mathrm{F}$; density $\left.=8.3 \mathrm{lb} / \mathrm{gal}\right)$

\section{3}

Plant

San Onofre

Connecticut

Yankee

R. E. Ginna

H. B. Robinson

Point Beach I

Point Beach 2

Surry 1

Turkey Point 3

Surry 2

Turkey Point 4

\begin{tabular}{llllllllllll}
$J$ & $F$ & $M$ & $A$ & $M$ & $J$ & $J$ & $A$ & $S$ & 0 & $N$ & $D$ \\
\hline 3 & 3 & 0 & 0 & 0 & 0 & 0 & 0 & 0 & 0 & $S$ & $S$ \\
0 & 0 & 0 & 0 & 10 & $S$ & 0 & $S$ & $S$ & $S$ & $S$ & 0
\end{tabular}

$\begin{array}{llllllllllll}0 & 0 & 0 & 0 & 0 & 0 & 0 & 0 & 0 & 0 & 0 & 0\end{array}$

$\begin{array}{llllllllllll}6 & 6 & 6 & \mathrm{~S} & 0 & 0 & 1 & 1 & 1 & 1 & 7 & 5\end{array}$

$\begin{array}{llllllllllll}S & S & 0 & 0 & 0 & 0 & 0 & 0 & 0 & 0 & 0 & 0\end{array}$

$\begin{array}{llllllllllll}0 & 0 & 0 & 0 & 0 & 0 & 0 & 0 & 0 & 0 & 0 & 0\end{array}$

$\begin{array}{llllllllllll}0 & 0 & 0 & 0 & 0 & 0 & 0 & 0 & 0 & 0 & 0 & 0\end{array}$

$\begin{array}{llllllllllll}0 & 0 & 0 & 0 & 0 & 0 & 0 & 0 & 0 & 0 & 0 & 0\end{array}$

$\begin{array}{llllllll}0 & 0 & 0 & 0 & 0 & 0 & 0 & 0\end{array}$

\section{4}

Plant

San Onofre

Connecticut

Yankee

R. E. Ginna

H. B. Robinson 2

Point Beach 1

Point Beach 2

Surry 1

Turkey Point 3

Surry 2

Turkey Point 4

Zion 1

Zion 2

Indian Point 2

Prairie Island 1

\begin{tabular}{llllllllllll}
$J$ & $F$ & $M$ & $A$ & $M$ & $J$ & $J$ & $A$ & $S$ & 0 & $N$ & $D$ \\
\hline 0 & 44 & 60 & 60 & 0 & 0 & 0 & 0 & 0 & 2 & 2 & 2 \\
0 & 0 & 0 & $S$ & 0 & 0 & 0 & 0 & 0 & 0 & 0 & 0
\end{tabular}

$\begin{array}{llllllllllll}S & S & S & 0 & 0 & 0 & 0 & 0 & 0 & 0 & 0 & 0\end{array}$

$\begin{array}{llllllllllll}2 & 10 & 112 & 98 & N A & 19 & 2 & 1 & 1 & 1 & 1 & 1\end{array}$

$\begin{array}{llllllllllll}0 & 0 & 0 & S & 0 & 0 & 0 & 0 & 0 & 0 & 0 & 0\end{array}$

$\begin{array}{llllllllllll}0 & 0 & 0 & 0 & 0 & 0 & 0 & 0 & 0 & 0 & S & S\end{array}$

$\begin{array}{llllllllllll}S & S & 0 & 0 & 0 & 115 & 55 & 115 & 115 & 4 & S & S\end{array}$

$\begin{array}{llllllllllll}0 & 0 & 0 & 0 & 0 & 0 & 0 & \text { NA } & \text { NA } & S & S & S\end{array}$

$\begin{array}{llllllllllll}0 & 0 & 0 & 0 & S & 38 & 0 & 0 & 0 & S & S & S\end{array}$

$\begin{array}{llllllllllll}S & 0 & 0 & 0 & 0 & 0 & 0 & 22 & 0 & 0 & 0 & 0\end{array}$

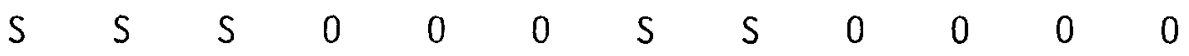

$0 \quad 0 \quad 0 \quad 0$

$\begin{array}{lllll}0 & 0 & 0 & 0 & 0\end{array}$

$\begin{array}{llllll}0 & 0 & 0 & 0 & 0 & 0\end{array}$ 
TABLE 2-11 (continued)

MONTHLY AVERAGE* PRIMARY/SECONDARY LEAKAGE

(gal/day at $70^{\circ} \mathrm{F}$; density $=8.3 \mathrm{lb} /$ gal)

$\underline{1975}$

\begin{tabular}{|c|c|c|c|c|c|c|c|c|c|c|c|c|}
\hline Plant & $\mathrm{J}$ & $F$ & M & A & $M$ & $\mathrm{~J}$ & $\mathrm{~J}$ & A & $S$ & 0 & $\mathrm{~N}$ & $D$ \\
\hline San Onofre & 2 & 2 & 2 & 2 & 3 & 5 & 0 & 0 & 0 & 0 & 0 & 0 \\
\hline $\begin{array}{l}\text { Connecticut } \\
\text { Yankee }\end{array}$ & 0 & 0 & 0 & 0 & 0 & $S$ & 0 & 0 & 0 & 0 & 0 & 0 \\
\hline R. E. Ginna & 0 & 0 & 3 & $S$ & 0 & 0 & 0 & 0 & 0 & 0 & 0 & 0 \\
\hline H. B. Robinson 2 & 1 & 1 & 1 & 3 & 1 & 5 & 3 & 2 & 0 & 0 & $S$ & 7 \\
\hline Point Beach 1 & 0 & 61 & $S$ & 0 & 1 & 2 & 2 & 2 & 1 & 2 & $S$ & $S$ \\
\hline Point Beach 2 & 0 & 0 & 0 & 0 & 0 & 0 & 0 & 1 & 0 & 0 & 0 & 0 \\
\hline Surry 1 & $S$ & 0 & 0 & 0 & 0 & 0 & 0 & 0 & 125 & $S$ & $S$ & 26 \\
\hline Turkey Point 3 & 0 & 0 & 0 & 0 & 0 & 0 & 0 & 0 & 0 & 0 & $S$ & $S$ \\
\hline Surry 2 & 0 & 0 & 0 & 0 & $\mathrm{~S}$ & 0 & 0 & 0 & 0 & 0 & 0 & 0 \\
\hline Turkey Point 4 & 0 & 0 & 0 & $S$ & $S$ & $S$ & 7 & 20 & 79 & 0 & 0 & 50 \\
\hline Zion 1 & 0 & 0 & $S$ & 0 & 0 & $S$ & 0 & 0 & $S$ & 0 & 0 & 0 \\
\hline Zion 2 & 0 & $S$ & 0 & 0 & 0 & $S$ & 0 & 0 & $S$ & 0 & 0 & 0 \\
\hline Indian Point 2 & 0 & 102 & $S$ & 0 & 0 & 0 & 0 & 0 & 0 & $\mathrm{~S}$ & 0 & 0 \\
\hline Prairie Island 1 & 0 & 0 & 0 & 0 & 0 & 0 & 0 & 0 & 0 & 0 & 0 & 0 \\
\hline Prairie Island 2 & 0 & 0 & 0 & 0 & 0 & 0 & 0 & 0 & 0 & 0 & 0 & 0 \\
\hline Cook 1 & & & & & & & & & 0 & 0 & 0 & 0 \\
\hline
\end{tabular}


TABLE 2-11 (continued)

MONTHLY AVERAGE* PRIMARY/SECONDARY LEAKAGE

(gal/day at $70^{\circ} \mathrm{F}$; density $\left.=8.3 \mathrm{lb} / \mathrm{gal}\right)$

\begin{tabular}{|c|c|c|c|c|c|c|c|c|c|c|c|c|}
\hline & & & & & & 19 & & & & & & \\
\hline Plant & J & $\mathrm{F}$ & M & A & M & $\mathrm{J}$ & $\mathrm{J}$ & A & $\mathrm{s}$ & 0 & $\mathrm{~N}$ & D \\
\hline San Onofre & 0 & 0 & 0 & 0 & 0 & 0 & 46 & 0 & 0 & $\mathrm{~s}$ & $\mathrm{~s}$ & $S$ \\
\hline $\begin{array}{l}\text { Connecticut } \\
\text { Yankee }\end{array}$ & 0 & 0 & 0 & 0 & $S$ & $S$ & 0 & 0 & 0 & $S$ & 0 & 0 \\
\hline R. E. Ginna & 0 & $S$ & $S$ & 14 & 0 & 0 & 0 & $S$ & 0 & $S$ & 0 & 0 \\
\hline H. B. Robinson 2 & 2 & 1 & 1 & 1 & 2 & 1 & 2 & 2 & 2 & 6 & $S$ & $S$ \\
\hline Point Beach 2 & 32 & 200 & 5 & 29 & 10 & 12 & 13 & 21 & 23 & 25 & 25 & 25 \\
\hline Surry 1 & 0 & 0 & 28 & 86 & NA & 19 & 39 & 14 & 33 & 1 & $S$ & $S$ \\
\hline Turkey Point 3 & 12 & 6 & 14 & 0 & 11 & 19 & 0 & 12 & 1 & $S$ & $\mathrm{~s}$ & S \\
\hline Surry 2 & 95 & 31 & 10 & 0 & $\mathrm{~s}$ & 0 & 0 & 0 & 6 & $\mathrm{~s}$ & $S$ & 200 \\
\hline Turkey Point 4 & 62 & 0 & 0 & $S$ & $\mathrm{~s}$ & $\mathrm{~s}$ & 0 & 0 & 80 & 42 & $\mathrm{~S}$ & 0 \\
\hline Zion 1 & 0 & 0 & $\mathrm{~s}$ & $S$ & $S$ & $\mathrm{~s}$ & 0 & 0 & 0 & $S$ & 0 & 0 \\
\hline Zion 2 & S & $S$ & 0 & $S$ & $S$ & 0 & 0 & 0 & 0 & $\mathrm{~s}$ & 0 & 0 \\
\hline Indian Point 2 & 0 & 0 & 0 & $\mathrm{~s}$ & $S$ & $\mathrm{~s}$ & $\mathrm{~s}$ & $s$ & $\mathrm{~s}$ & 139 & $\mathrm{~s}$ & $S$ \\
\hline Prairie Island 1 & 0 & 0 & $S$ & $S$ & 0 & 0 & 0 & 0 & 0 & 0 & 0 & 0 \\
\hline Prairie Island 2 & $S$ & 0 & 0 & 0 & 0 & 0 & 0 & 0 & 0 & $S$ & $S$ & $S$ \\
\hline Cook 1 & 0 & 0 & 0 & $S$ & $S$ & 0 & 0 & 0 & 0 & 0 & 0 & 0 \\
\hline Trojan & & & & & 0 & $s$ & $S$ & $S$ & 0 & $S$ & $S$ & 0 \\
\hline Indian Point 3 & & & & & & & & 0 & $S$ & 0 & 0 & 0 \\
\hline Point Beach 1 & 0 & 0 & 3 & 3 & 3 & 2 & 3 & 3 & 3 & $\mathrm{~s}$ & $\mathrm{~s}$ & 0 \\
\hline
\end{tabular}


TABLE 2-11 (continued)

MONTHLY AVERAGE* PRIMARY/SECONDARY LEAKAGE

(gal/day at $70^{\circ} \mathrm{F}$; density $=8.3 \mathrm{lb} / \mathrm{gal}$ )

$\underline{1977}$

Plant

\begin{tabular}{llllllllllll}
$J$ & $F$ & $M$ & $A$ & $M$ & $J$ & $J$ & $A$ & $S$ & 0 & $N$ & $D$ \\
\hline
\end{tabular}

San Onofre $\begin{array}{llllllllllll}S & S & S & 0 & 0 & 1 & 2 & 2 & S & 0 & 2 & 1\end{array}$

Connecticut $\begin{array}{llllllllllll}0 & 0 & 0 & 0 & 0 & 0 & 0 & 0 & 0 & S & S & 0\end{array}$

R. E. Ginna $0 \quad 0$

0

H. B. Robinson 2

Point Beach 1 $\begin{array}{llllllllllll}4 & 5 & 3 & 6 & 3 & 5 & 5 & 5 & 4 & 5 & 8 & 7\end{array}$

Point Beach 2 $\begin{array}{llllllllllll}25 & 35 & 33 & \mathrm{~S} & 0 & 0 & 0 & 0 & 0 & 0 & 0 & 0\end{array}$

Surry 1 $\begin{array}{llllllllllll}\mathrm{S} & 77 & 144 & 53 & 0 & 0 & 0 & 26 & 58 & 58 & 21 & 0\end{array}$

Turkey Point 3 $\begin{array}{llllllll}0 & 0 & 0 & 0 & 0 & 0 & 0 & 28\end{array}$

Surry 2 $\begin{array}{llllllllllll}548 & 360 & \mathrm{~S} & 0 & \mathrm{NA} & 18 & 10 & 8 & 4 & 0 & 14 & 0\end{array}$

Turkey Point 4 $\begin{array}{lllllll}23 & 29 & 71 & 96 & 7 & S\end{array}$

Zion 1 $\begin{array}{llllllllllll}0 & 0 & 0 & 0 & 0 & 0 & 0 & 0 & \mathrm{~S} & \mathrm{~S} & \mathrm{~S} & 0\end{array}$

Zion 2 $\begin{array}{lllll}S & S & S & 0 & 0\end{array}$

Indian Point 2 $\begin{array}{lllll}0 & 0 & 0 & S & 0\end{array}$

Prairie Island $1 \quad 0 \quad 0 \quad 0 \quad \mathrm{~S}$

$\begin{array}{lllllllllllll}\text { Prairie Island } 2 & 0 & 0 & 0 & 0 & 0 & 0 & 0 & 0 & 0 & 1 & S & S\end{array}$

Cook 1 $\begin{array}{llllllllllll}\mathrm{S} & \mathrm{S} & 0 & 0 & 0 & 0 & 0 & 0 & 0 & 0 & 0 & 0\end{array}$

Trojan $\begin{array}{llllllllllll}0 & 0 & 0 & 0 & S & S & 0 & 0 & 0 & 0 & 0 & 0\end{array}$

Indian Point 3 $\begin{array}{lll}0 & 0 & 0\end{array}$

Beaver Valley 1 $0 \quad 0$

Salem 1 $\begin{array}{llllll}0 & 0 & 0 & S & S & 0\end{array}$

Farley 1 
TABLE 2-11 (continued)

MONTHLY AVERAGE* PRIMARY/SECONDARY LEAKAGE

(gal/day at $70^{\circ} \mathrm{F}$; density $\left.=8.31 \mathrm{~b} / \mathrm{ga} 1\right)$

1978

\begin{tabular}{|c|c|c|c|c|c|c|c|}
\hline Plant & $\mathrm{J}$ & $\mathrm{F}$ & M & A & $M$ & $\mathrm{~J}$ & Average,* gal/day \\
\hline San Onofre & 1 & 1 & 1 & $S$ & 1 & 1 & 4.6 \\
\hline $\begin{array}{l}\text { Connecticut } \\
\text { Yankee }\end{array}$ & 0 & 0 & 0 & 0 & 0 & 0 & 5.7 \\
\hline R. E. Ginna & 4 & 0 & 0 & S & S & 0 & 0.27 \\
\hline H. B. Robinson 2 & 441 & $S$ & $s$ & 18 & 88 & 190 & 21 \\
\hline Point Beach 1 & 20 & 7 & 7 & 7 & 120 & 7 & 15 \\
\hline Point Beach 2 & 0 & 0 & 0 & $S$ & 0 & 0 & 7.9 \\
\hline Surry 1 & 0 & 0 & 0 & 0 & $S$ & $S$ & 22 \\
\hline Turkey Point 3 & $\mathrm{~S}$ & 0 & 0 & 0 & 0 & 0 & 5.5 \\
\hline Surry 2 & 0 & 46 & 278 & 0 & 0 & 0 & 32. \\
\hline Turkey Point 4 & 36 & 193 & 0 & 0 & 0 & 0 & 17. \\
\hline Zion 1 & 0 & 0 & 0 & 0 & 0 & 0 & 0 \\
\hline Zion 2 & 0 & $S$ & $S$ & $S$ & S & 0 & 0 \\
\hline Indian Point 2 & 0 & $S$ & $S$ & S & $S$ & 0 & 7.8 \\
\hline Prairie Island 1 & 0 & 0 & 0 & S & 0 & 0 & 0 \\
\hline Prairie Island 2 & 0 & 0 & 0 & 0 & 0 & 0 & 0.03 \\
\hline Cook 1 & 0 & 0 & 0 & $S$ & $S$ & $S$ & 0 \\
\hline Trojan & 2 & 2 & 2 & $S$ & $S$ & $S$ & 0.38 \\
\hline Indian Point 3 & 0 & 0 & 0 & 0 & 0 & $S$ & 0 \\
\hline Beaver Valley 1 & 0 & 0 & 0 & 0 & $S$ & $S$ & 0 \\
\hline Salem 1 & 0 & 0 & 0 & $S$ & $S$ & $S$ & 0 \\
\hline Farley 1 & 0 & 0 & 0 & 0 & 0 & 0 & 0 \\
\hline \multicolumn{7}{|c|}{ Operation Weighted Average } & 9 \\
\hline
\end{tabular}

* Average daily value for each reactor is obtained by the sum of the total monthly leakage rates divided by the total number of days in operation. 
TABLE 2-12

MOISTURE CARRYOVERS IN RECIRCULATING U-TUBE

STEAM GENERATORS*

Facility

Palisades

Kansai

Point Beach

Turkey Point 3

Turkey Point 4

Average
Percent Carryovers

0.08

0.05

0.2

0.6

1.6

0.5
Reference

10,11

10,11

8,12

6

6

* Measurement based on Na concentration. 
The category "Other Nuclides" includes Mo, Y, and Tc which are generally present in colloidal suspensions or as "crud." Although the actual

removal mechanism for $Y$, Mo, and Tc is expected to be plateout or filtration, the quantitative effect of removal is expected to be commensurate with the removal of ionic impurities by ion exchange (within the accuracy of the calculations) and consequently plateout of these nuclides is included in the parameters for ion exchange.

\subsubsection{IODINE RELEASES FROM BUILDING VENTILATION SYSTEMS}

\subsubsection{Parameter}

The iodine releases from building ventilation systems prior to treatment are calculated by the PWR-GALE Code using the data in Tables 1-1, Tables 2-2 through 2-8 and 2-13 through 2-16.

\subsubsection{Bases}

The iodine-131 releases from building ventilation systems are based on measurements made at a number of operating reactors. The measurements were made during routine plant operation and during plant shutdowns. Work on identifying sources of radioiodine at PWR's has been conducted by C. Pelletier, et al. (Ref. 7) for the Electric Power Research Institute (EPRI), at three operating PWR's; Ginna, Calvert Cliffs 1, and Three Mile Island 1. Measurements have also been made by EG\&G Idaho, Inc., Allied Chemical Corp., Idaho National Engineering Laboratory, for the U. S. Nuclear Regulatory Commission at Fort Calhoun (Ref. 4), Zion 1 and 2 (Ref. 5), Turkey Point 3 and 4 (Ref. 6), Prairie Island (Ref.42), and Rancho Seco (Ref. 43).

These measurements indicate that iodine-131 bujlding vent releases are directly related to the reactor coolant iodine-131 concentration. As a result, the releases of iodine are expressed as "normalized" releases, that is, the absolute measured release rate in $\mathrm{Ci} / \mathrm{yr}$ is divided by the reactor coolant concentration in $\mu \mathrm{Ci} / \mathrm{g}$ to give a "normalized" release rate of iodine-131 in $\mathrm{Ci} / \mathrm{yr} / \mu \mathrm{Ci} / \mathrm{g}$ as shown in the following equation:

$$
R_{N}=\frac{R_{A}}{C_{R W}}
$$

where

$$
\begin{aligned}
& R_{N}=\text { normalized release rate of iodine-131, } \mathrm{Ci} / \mathrm{yr} / \mu \mathrm{Ci} / \mathrm{g} \\
& R_{A}=\text { absolute (measured) iodine }-131 \text { release rate, } \mathrm{Ci} / \mathrm{yr} \\
& C_{R W}=\text { measured reactor water iodine-131 concentration, } \mu \mathrm{Ci} / \mathrm{g}
\end{aligned}
$$


TABLE 2-13

ANNUAL IODINE NORMALIZED RELEASES

FROM CONTAINMENT VENTILATION SYSTEMS†

NORMAL OPERATION LEAK RATE*

Normalized Release/Unit

Data Source

Ft. Calhoun (Ref. 4)

Three Mile Island 1 (Ref. 7)

Turkey Point 3/4 (Ref.6)

Main Yankee (Ref. 16)

Ginna (Ref. 19)

Yankee Rowe (Ref. 14, 16)

Prairie Island $1 / 2$ (Ref. 42)

Rancho Seco (Ref. 43)

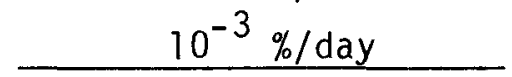

0.0014

2.5

0.9

0.1

0.064

1.0

0.005

2.56

0.80

Average

RELEASE FOR EXTENDED OUTAGES**

Data Source

Three Mile Island I (Ref. 7)

Calvert Cliffs 1 (Ref. 7)

Average
Normalized Release/Unit $(\mathrm{Ci} / \mathrm{yr} / \mu \mathrm{Ci} / \mathrm{g})$

0.44

0.19

0.32

* The normalized release rate, expressed in \%/day of leakage of primary coolant inventory of iodine, represents the effective leak rate for radioiodine. It is the combination of the reactor water leakage rate into the buildings, and the partitioning of the radioiodine between the water phase in the leakage and the gas phase where it is measured.

** The normalized release rate, expressed in $\mathrm{C} i / \mathrm{yr} / \mu \mathrm{C} i / g$, represents the effective leak rate for radioiodine. It is the combination of the reactor water iodine leakage rate into the buildings, and the partitioning of the radioiodine between the water phase in the leakage and the gas phase where it is measured.

† These results were obtained using ${ }^{131_{I}}$ data. The normalized release rates are applicable to both ${ }^{131} \mathrm{I}$ and ${ }^{133} \mathrm{I}$. 
TABLE 2-14

ANNUAL IODINE NORMALIZED RELEASES*

FROM AUXILIARY BUILDING VENTILATION SYSTEMST

NORMAL OPERATION

Data Source

Zion $1 / 2$ (Ref. 5)

Fort Calhoun (Ref. 4)

Ginna (Ref. 7)

Calvert Cliffs 1 (Ref. 7)

Three Mile Island 1 (Ref. 7)

Turkey Point $3 / 4$ (Ref. 6)

Prairie Island 1/2 (Ref. 42)

Rancho Seco (Ref. 43)

Average

SHUTDOWN

Data Source

Ginna (Ref. 7)

Calvert Cliffs 1 (Ref. 7)

Three Mile Island 1 (Ref. 7)

Turkey Point 3/4 (Ref. 6)

Rancho Seco (Ref. 43)

Average
Normalized Release/Unit $(\mathrm{Ci} / \mathrm{yr} / \mu \mathrm{Ci} / \mathrm{g})$

1.0

0.12

0.032

0.57

0.034

1.85

0.013

0.97

0.68

Normalized Release/Unit $(\mathrm{Ci} / \mathrm{yr} / \mu \mathrm{Ci} / \mathrm{g})$

0.08

0.016

0.14

6.8

1.14

2.50

* The normalized release rate, expressed in $\mathrm{C} i / \mathrm{yr} / \mu \mathrm{C} j / \mathrm{g}$ during different modes of operation, represents the effective leak rate for radioiodine. It is the combination of the reactor water iodine leakage rate into the buildings and the partitioning of the radioiodine between the water phase in the leakage and the gas phase where it is measured.

t These results were obtained using ${ }^{131}$ I data. The normalized release rates are applicable to both ${ }^{131}$ I and ${ }^{133}$ I. 
TABLE 2-15

ANNUAL IODINE NORMALIZED RELEASES*

FROM REFUELING AREA VENTILATION SYSTEMS†

NORMAL OPERATION

Data Source

Ginna (Ref. 7)

Calvert Cliffs 1 (Ref. 7)

Three Mile Island 1 (Ref. 7)

Turkey Point 3 (Ref. 6)

Prairie Island $1 / 2$ (Ref. 42)

Rancho Seco (Ref. 43)

Average

SHUTDOWN

Data Source

Ginna (Ref. 7)

Calvert Cliffs 1 (Ref. 7)

Three Mile Is 1 and 1 (Ref. 7)

Turkey Point 3 (Ref. 6)

Rancho Seco (Ref. 43)

Average
Normalized Release/Unit

$(\mathrm{Ci} / \mathrm{yr} / \mu \mathrm{Ci} / \mathrm{g})$

$$
\begin{aligned}
& 0.008 \\
& 0.049 \\
& 0.0012 \\
& 0.16 \\
& 0.019 \\
& 0.01 \\
& \hline 0.038
\end{aligned}
$$

Normalized Release/Unit $(\mathrm{Ci} / \mathrm{yr} / \mathrm{Ci} / \mathrm{g})$

$$
\begin{aligned}
& 0.014 \\
& 0.039 \\
& 0.06 \\
& 0.05 \\
& 0.30 \\
& \hline 0.093
\end{aligned}
$$

* The normalized release rate, expressed in $\mathrm{C} i / \mathrm{yr} / \mu \mathrm{Ci} / \mathrm{g}$ during different modes of operation, represents the effective leak rate for radioiodine. It is the combination of the reactor water iodine leakage rate into the building, and the partitioning of the radioiodine between the water phase in the leakage and the gas phase where it is measured.

+ These results were obtained using ${ }^{131}$ I data. The normalized release rates are applicable to both ${ }^{131} \mathrm{I}$ and ${ }^{133} \mathrm{I}$. 
TABLE 2-16*

ANNUAL IODINE NORMALIZED RELEASES **

FROM TURBINE BUILDING VENTILATION SYSTEMS

NORMAL OPERATION

\section{Data Source}

Monticello

Oyster Creek

Vermont Yankee

Pilgrim

Browns Ferry

References 3,5 of Ref. 15

Average

EXTENDED SHUTDOWN

Data Source

Monticello

Oyster Creek

Vermont Yankee

Browns Ferry

References 3, 5 of Ref. 15

Average
Normalized Release/Unit $(\mathrm{Ci} / \mathrm{yr} / \mu \mathrm{Ci} / \mathrm{g})$

$$
\begin{aligned}
& 3.1 \times 10^{3} \\
& 6.0 \times 10^{3} \\
& 0.35 \times 10^{3} \\
& 8.5 \times 10^{3} \\
& 1.3 \times 10^{3} \\
& 3.3 \times 10^{3} \\
& \hline 3.8 \times 10^{3}
\end{aligned}
$$

Normalized Release/Unit $(\mathrm{Ci} / \mathrm{yr} / \mu \mathrm{Ci} / \mathrm{g})$

$$
\begin{aligned}
& 1.7 \times 10^{2} \\
& 3.5 \times 10^{2} \\
& 0.63 \times 10^{2} \\
& 1.3 \times 10^{2} \\
& 1.4 \times 10^{3} \\
& \hline 4.2 \times 10^{2}
\end{aligned}
$$

* The data in this table are taken from Table 2-8, NUREG-0016, Revision 1, January 1979 (Ref. 15).

** The normalized release rate, expressed in $\mathrm{Ci} / \mathrm{yr} / \mu \mathrm{Ci} / \mathrm{g}$ during different modes of operation represents the effective leak rate for radioiodine. It is a function of iodine leak rate via steam and the partition coefficient for radioiodine from reactor water to steam in the reactor vessel.

$\dagger$ These results were obtained using ${ }^{131} \mathrm{I}$ data. The normalized release rates are applicable to both ${ }^{131} \mathrm{I}$ and ${ }^{133} \mathrm{I}$. 
The normalized reactor water release rate, expressed in $\mathrm{Ci} / \mathrm{yr} / \mu \mathrm{Ci} / \mathrm{g}$ represents an effective leak rate for reactor water containing iodine. It is the combination of the water leakage rate into the building and the effect of iodine partitioning between the water phase in the systems leakage and the vapor phase in the building atmosphere.

For the turbine building, the secondary coolant iodine releases are directly related to the secondary coolant iodine-131 concentration. Therefore, for the turbine building, the normalized iodine release, $R_{N}$, is determined using the following expression:

$$
R_{N}=\frac{R_{A}}{C_{R W} \times P C}
$$

where

$$
\begin{aligned}
& R_{N}=\begin{array}{c}
\text { normalized release rate of secondary coolant water containing } \\
\text { iodine }-131, \mathrm{Ci} / \mathrm{yr} / \mu \mathrm{Ci} / \mathrm{g}
\end{array} \\
& R_{A}=\text { absolute (measured) iodine-131 release rate, } \mathrm{Ci} / \mathrm{yr} \\
& C_{R W}=\text { measured secondary coolant iodine-131 concentration, } \mu \mathrm{Ci} / \mathrm{g} \\
& P C \text { = measured iodine partition coefficient from secondary coolant }
\end{aligned}
$$

The normalized release rate is used to estimate the release from PWR's since this expression for release rate is least variable with time for a given mode of operation. For this reason, it is useful in the determination of releases from PWR's.

Data on normalized release rates from the three reactors used in the EPRI study and the five reactors used in the NRC sponsored study are given for normal operation and shutdown periods in Tables 2-13 through 2-15, for the containment building, auxiliary building and refueling area, respectively. Also given in Table 2-13 is the normalized value of the iodine release data discussed in NUREG-0017, April 1976 (Ref. 14). For Table 2-16, it was considered that since the basic design and operation of PWR and BWR power generation equipment which is housed in the turbine building is essentially identical, the turbine building leakage rates from PWR's and BWR's should be similar. Therefore, for the PWR turbine building normalized iodine release rate, the values for BWR's given in Table 2-15 of NUREG-0016, Revision 1 (Ref. 15) have been used and reproduced here as Table 2-16 of this report.

The data in Tables 2-14 through 2-16 are expressed as total normalized releases during power operation of 300 days and the total normalized releases during shutdowns of 65 days. Since the reactors used in the EPRI study and the NRC study experienced several intermittent 
shutdowns of short duration during the power operation measurement period, the iodine releases during these short duration outages are included under power operation.

Since the releases from the containment building are dependent on the method of containment purging (see Section 2.2.9, Containment Purging Frequency), the releases in Table 2-13 are expressed in terms of a leak rate (in \%/day of primary coolant inventory). In addition, the release from the containment building during extended outages is expressed as a total normalized release as discussed above for other buildings.

In order to obtain the releases in curies/year from the auxiliary building and the refueling area of a particular PWR, the normalized release data in Tables 2-14 and 2-15, respectively, are multiplied in the PWRGALE Code by the iodine concentrations in the reactor coolant for that particular PWR using the following expression:

$$
R_{\text {PWRi }}=R_{N} \times C_{P W R i}
$$

where

$$
\begin{aligned}
R_{\text {PWR }}= & \begin{array}{c}
\text { calculated annual release rate for particular PWR for iodine } \\
\text { isotope } i, \mathrm{C} i / y r
\end{array} \\
\mathrm{R}_{\mathrm{N}}= & \text { normalized annual release rate of iodine from Tables } 2-14 \\
& \text { and } 2-15, \mathrm{Ci} / \mathrm{yr} / \mu \mathrm{Ci} / \mathrm{g} \\
\mathrm{C}_{\text {PWRi }}= & \begin{array}{l}
\text { calculated reactor water concentration for particular } \\
\text { PWR for } i \text { odine isotope } i, \mu \mathrm{C} / \mathrm{g}
\end{array}
\end{aligned}
$$

To obtain the release in curies/year from the turbine building of a particular PWR, the normalized release data in Table 2-16 are multiplied in the PWR-GALE Code by the iodine concentration in the secondary coolant water and the iodine partition coefficient from the water to steam in the steam generator for that particular PWR using the following expression:

$$
R_{\text {PWR }}=R_{N} \times S C_{P W R i} \times P C_{P W R}
$$

where

$$
\begin{aligned}
R_{\text {PWRi }}= & \begin{array}{l}
\text { calculated annual release rate for particular PWR for iodine } \\
\text { isotope } i, \mathrm{C} i / \mathrm{yr}
\end{array} \\
\mathrm{R}_{\mathrm{N}}= & \begin{array}{l}
\text { normalized annual release rate of iodine from Table } 2-16, \\
\mathrm{Ci} / \mathrm{yr} / \mu \mathrm{Ci} / \mathrm{g}
\end{array}
\end{aligned}
$$




$$
\begin{aligned}
\mathrm{SC}_{\mathrm{PWR} i}= & \text { calculated secondary coolant concentration for particular } \\
& \text { PWR for iodine isotope } \mathrm{i}, \mu \mathrm{C} i / \mathrm{g} \\
\mathrm{PC} & \\
\mathrm{PWR}= & \begin{array}{l}
\text { partition coefficient from the secondary coolant water to } \\
\text { steam for the particular PWR (see Table 2-6) }
\end{array}
\end{aligned}
$$

In order to obtain the releases in curies/year from the containment building of a particular PWR, the normalized leak rates in Table 2-13, are multplied in the PWR-GALE Code by the iodine concentration in the reactor coolant for that particular PWR, and then this leak rate is considered along with the containment purging method for that particular PWR.

To obtain the releases during shutdown, multiply the normalized release rates for the shutdown period by the same reactor coolant concentration as for power operations. Use of this reactor coolant concentration is acceptable since the normalization technique based the shutdown normalized release rate on the reactor coolant concentrations prior to shutdown.

Iodine released from PWR building ventilation systems appear in one of the following chemical forms: particulate, elemental, hypoiodious acid (HOI) and organic. Based on data in References 4, 5, 6, 7, 42 and 43, the fraction of the iodine appearing in each of the chemical forms for each building ventilation system is given below:

\begin{tabular}{|c|c|c|c|c|}
\hline & Containment & Auxiliary & Turbine & Fuel Handling \\
\hline $\begin{array}{l}\text { Particulate } \\
\text { Elemental } \\
\text { HOI } \\
\text { Organic }\end{array}$ & $\begin{array}{l}0.09 \\
0.21 \\
0.21 \\
0.49\end{array}$ & $\begin{array}{l}0.04 \\
0.21 \\
0.22 \\
0.53\end{array}$ & $\begin{array}{l}* \\
0.78 \\
*\end{array}$ & $\begin{array}{l}0.01 \\
0.17 \\
0.57 \\
0.25\end{array}$ \\
\hline
\end{tabular}

FRACTION OF IODINE APPEARING IN EACH CHEMICAL FORM FROM PWR BUILDING VENTILATION SYSTEMS

\subsubsection{RADIOACTIVE PARTICULATES RELEASED IN GASEOUS EFFLUENTS}

\subsubsection{Parameter}

Use the radioactive particulate release rates in gaseous effluents given in Table 2-17. 
TABLE 2-17

PARTICULATE RELEASE RATE FOR GASEOUS EFFLUENTS*

$(\mathrm{Ci} / \mathrm{yr}) /$ unit

\begin{tabular}{|c|c|c|c|c|}
\hline Nuclide & Containment & $\begin{array}{l}\text { Auxiliary } \\
\text { Building } \\
\end{array}$ & $\begin{array}{c}\text { Fuel Pool } \\
\text { Area } \\
\end{array}$ & $\begin{array}{c}\text { Waste Gas } \\
\text { System } \\
\end{array}$ \\
\hline $\begin{array}{l}\mathrm{Cr}-51 \\
\mathrm{Mn}-54 \\
\mathrm{Co}-57 \\
\mathrm{Co}-58 \\
\mathrm{Co}-60 \\
\mathrm{Fe}-59 \\
\mathrm{Sr}-89 \star \star \\
\mathrm{Sr}-90 \star \star \\
\mathrm{Zr}-95 \\
\mathrm{Nb}-95 \\
\mathrm{Ru}-103 \\
\mathrm{Ru}-106 \\
\mathrm{Sb}-125 \\
\mathrm{Cs}-134 \\
\mathrm{Cs}-136 \\
\mathrm{Cs}-137 \\
\mathrm{Ba}-140 \\
\mathrm{Ce}-141\end{array}$ & $\begin{array}{l}9.2(-3) \\
5.3(-3) \\
8.2(-4) \\
2.5(-2) \\
2.6(-3) \\
2.7(-3) \\
1.3(-2) \\
5.2(-3) \\
N A \\
1.8(-3) \\
1.6(-3) \\
N A \\
N A \\
2.5(-3) \\
3.2(-3) \\
5.5(-3) \\
N A \\
1.3(-3)\end{array}$ & $\begin{array}{c}3.2(-4) \\
7.8(-5) \\
N A \\
1.9(-3) \\
5.1(-4) \\
5.0(-5) \\
7.5(-4) \\
2.9(-4) \\
1.0(-3) \\
3.0(-5) \\
2.3(-5) \\
6.0(-6) \\
3.9(-6) \\
5.4(-4) \\
4.8(-5) \\
7.2(-4) \\
4.0(-4) \\
2.6(-5)\end{array}$ & $\begin{array}{l}7.8(-4) \\
3.0(-4) \\
N A \\
2.1(-2) \\
8.2(-3) \\
N A \\
2.1(-3) \\
8.0(-4) \\
3.6(-6) \\
2.4(-3) \\
3.8(-5) \\
6.9(-5) \\
5.7(-5) \\
1.7(-3) \\
N A \\
2.7(-3) \\
N A \\
4.4(-7)\end{array}$ & $\begin{array}{l}1.4(-5) \\
2.1(-6) \\
\text { NA } \\
8.7(-6) \\
1.4(-5) \\
1.8(-6) \\
4.4(-5) \\
1.7(-5) \\
4.8(-6) \\
3.7(-6) \\
3.2(-6) \\
2.7(-6) \\
\text { NA } \\
3.3(-5) \\
5.3(-6) \\
7.7(-5) \\
2.3(-5) \\
2.2(-6)\end{array}$ \\
\hline
\end{tabular}

* Particulate release rates are prior to filtration.

NA - No release observed from this source. Release assumed to be less than 1\% of total.

** Data not available from Ref. 4, 5, 6 or 7, therefore Sr-89 and Sr-90 data were extracted from Semi-annual Effluent Release Reports. Release from each area above calculated by use of percent released from each area from Ref. 4, 5, 6 and 7 data. 


\subsubsection{Bases}

Tables 2-18 through 2-21 list measured particulate releases at 12 operating reactors (Ref. $4,5,6,7,42$, and 43). The average annual release rates for each nuclide released from four sources within the plant have been calculated based on the data in Tables 2-18 through 2-21. The measurements shown in Tables 2-18 through 2-21 were taken upstream of HEPA filters on streams on which HEPA filters are located. Based on the data in Tables $2-18$ through $2-21,63 \%$ of the releases came from the containment, $5 \%$ from the auxiliary building, $31 \%$ from the fuel pool area, and less than 1\% from the waste gas processing system.

\subsubsection{NOBLE GAS RELEASES FROM BUILDING VENTILATION SYSTEMS \\ 2.2.6.1 Parameter}

The noble gas releases from building ventilation systems are based on a daily leak rate of $3 \%$ of the noble gas inventory in the primary coolant released to the containment atmosphere; on a $160 \mathrm{lb} /$ day primary coolant leak to the auxiliary building; and on a $1700 \mathrm{lb} / \mathrm{hr}$ steam leak rate in the turbine building.

\subsubsection{Bases}

The containment building leakage rate is derived from xenon-133 measurements in the containment atmosphere at Ginna and Maine Yankee (Ref. 17). The xenon-133 concentrations in the containment atmospheres at steady state were approximately $5 \times 10^{-3} \mu \mathrm{C} i / \mathrm{Cc}$ for Main Yankee and $7 \times 10^{-3} \mu \mathrm{Ci} / \mathrm{cc}$ for Ginna. The containment volumes at these facilities are approximately $1.8 \times 10^{6} \mathrm{ft}^{3}$ for Maine Yankee and $1 \times 10^{6} \mathrm{ft}^{3}$ for Ginna. Based on these values, the total microcuries of xenon-133 in the containment building atmosphere are

Maine Yankee

$\left(5 \times 10^{-3} \mu \mathrm{Ci} / \mathrm{cc}\right)\left(1.8 \times 10^{6} \mathrm{ft}^{3}\right)\left(2.83 \times 10^{4} \mathrm{cc} / \mathrm{ft}^{3}\right)=2.5 \times 10^{8} \mu \mathrm{Ci} \mathrm{Xe}-133$

Ginna

$$
\left(7 \times 10^{-3} \mu \mathrm{Ci} / \mathrm{cc}\right)\left(1 \times 10^{6} \mathrm{ft}^{3}\right)\left(2.83 \times 10^{4} \mathrm{cc} / \mathrm{ft}^{3}\right)=2.0 \times 10^{8} \mu \mathrm{Ci} \times \mathrm{e}-133
$$

Based on the half-life of xenon-133 (5.3d) and the assumption of a constant leakage rate to containment, the daily leakage rate of xenon- 133 to the containment for the two plants is

Ma in Yankee

$$
\frac{2.5 \times 10^{8} \mu \mathrm{Ci}}{(5.3 \mathrm{day} / 0.693)}=3.3 \times 10^{7} \mu \mathrm{Ci} / \text { day } \mathrm{Xe}-133 \text { leakage }
$$


TABLE $2-18$

MEASURED RELEASES UPSTREAM OF HEPA FILTERS - CONTAINMENT

\section{(Ci/yr)}

\begin{tabular}{|c|c|c|c|c|c|c|c|c|c|}
\hline Nuclide & $\begin{array}{l}\text { Three Mile } \\
\text { Island } 1 \\
\text { (Ref. 7) } \\
\end{array}$ & $\begin{array}{c}\text { Fort Calhoun } \\
\text { (Ref. 4) } \\
\end{array}$ & $\begin{array}{c}\text { Zion } 1 \& 2 \\
(\operatorname{Ref.} 5)^{2} \\
\end{array}$ & $\begin{array}{l}\text { Turkey } \\
\text { Point } \\
3 \& 4 \\
\text { (Ref. 6) } \\
\end{array}$ & $\begin{array}{l}\text { Calvert } \\
\text { Cliffs } 1 \\
\text { (Ref. } 7 \text { ) } \\
\end{array}$ & $\begin{array}{c}\text { Ginna } \\
\text { (Ref. 7) } \\
\end{array}$ & $\begin{array}{l}\text { Prairie } \\
\text { Island } \\
1 \& 2 \\
\text { (Ref. 42) }\end{array}$ & $\begin{array}{c}\text { Rancho } \\
\text { Seco } \\
\text { (Ref. 43) }\end{array}$ & $\begin{array}{c}\text { Average } \\
(\mathrm{Ci} / \mathrm{yr}) / \text { unit }\end{array}$ \\
\hline $\begin{array}{l}\mathrm{Cr}-51 \\
\mathrm{Mn}-54 \\
\mathrm{Co}-57 \\
\mathrm{Co}-58 \\
\mathrm{Co}-60 \\
\mathrm{Fe}-59 \\
\mathrm{Zr}-95 \\
\mathrm{Nb}-95 \\
\mathrm{Ru}-103 \\
\mathrm{Ru}-106 \\
\mathrm{Sb}-125 \\
\mathrm{Cs}-134 \\
\mathrm{C} s-136 \\
\mathrm{Cs}-137 \\
\mathrm{Ba}-140 \\
\mathrm{Ce}-141\end{array}$ & $\begin{array}{c}5.5(-2) \\
2.1(-2) \\
4.9(-3) \\
2.2(-1) \\
2.3(-2) \\
1.6(-2) \\
N A \\
1.1(-2) \\
9.5(-3) \\
N A \\
N A \\
2.1(-2) \\
1.9(-2) \\
4.4(-2) \\
N A \\
8.0(-3)\end{array}$ & $\begin{array}{l}\text { ND } \\
1.4(-8) \\
\text { ND } \\
5.6(-8) \\
3.8(-8) \\
\text { ND } \\
\text { NA } \\
\text { ND } \\
\text { ND } \\
\text { NA } \\
\text { NA } \\
3.2(-6) \\
\text { ND } \\
4.1(-6) \\
\text { NA } \\
\text { ND }\end{array}$ & $\begin{array}{l}\text { ND } \\
3.9(-6) \\
\text { ND } \\
1.5(-5) \\
1.2(-5) \\
\text { ND } \\
\text { NA } \\
\text { ND } \\
\text { ND } \\
\text { NA } \\
\text { NA } \\
2.3(-4) \\
\text { ND } \\
3.2(-4) \\
\text { NA } \\
\text { ND }\end{array}$ & $\begin{array}{l}\text { ND } \\
\text { NA } \\
\text { ND } \\
3.2(-6) \\
3.0(-5) \\
\text { ND } \\
\text { NA } \\
\text { ND } \\
\text { ND } \\
\text { NA } \\
\text { NA } \\
7.7(-5) \\
\text { ND } \\
7.9(-4) \\
\text { NA } \\
\text { ND }\end{array}$ & $\begin{array}{l}\text { NA } \\
\text { NA } \\
\text { NA } \\
\text { NA } \\
\text { NA } \\
\text { NA } \\
\text { NA } \\
\text { NA } \\
\text { NA } \\
\text { NA } \\
\text { NA } \\
\text { NA } \\
\text { NA } \\
\text { NA } \\
\text { NA } \\
\text { NA }\end{array}$ & $\begin{array}{l}\text { NA } \\
\text { NA } \\
\text { NA } \\
\text { NA } \\
\text { NA } \\
\text { NA } \\
\text { NA } \\
\text { NA } \\
\text { NA } \\
\text { NA } \\
\text { NA } \\
\text { NA } \\
\text { NA } \\
\text { NA } \\
\text { NA } \\
\text { NA }\end{array}$ & $\begin{array}{c}\text { NA } \\
\text { NA } \\
\text { NA } \\
6.6(-8) \\
1.4(-7) \\
\text { NA } \\
\text { NA } \\
\text { NA } \\
\text { NA } \\
\text { NA } \\
\text { NA } \\
3.2(-8) \\
\text { NA } \\
6.6(-8) \\
\text { NA } \\
\text { NA }\end{array}$ & $\begin{array}{l}\text { NA } \\
\text { NA } \\
\text { NA } \\
2.5(-3) \\
3.3(-4) \\
\text { NA } \\
\text { NA } \\
\text { NA } \\
\text { NA } \\
\text { NA } \\
\text { NA } \\
1.5(-3) \\
\text { NA } \\
5.0(-3) \\
\text { NA } \\
\text { NA }\end{array}$ & $\begin{array}{c}9.2(-3) \\
5.3(-3) \\
8.2(-4) \\
2.5(-2) \\
2.6(-3) \\
2.7(-3) \\
\text { NA } \\
1.8(-3) \\
1.6(-3) \\
\text { NA } \\
\text { NA } \\
2.5(-3) \\
3.2(-3) \\
5.5(-3) \\
\text { NA } \\
1.3(-3)\end{array}$ \\
\hline
\end{tabular}

ND $=$ Not detected. For averaging purposes, a value of zero was assumed.

$N A=$ Not analyzed (or no measurement taken); plants not included in averaging. 
TABLE 2-19

MEASURED RELEASES UPSTREAM OF HEPA FILTERS - AUXILIARY BUILDING $(\mathrm{Ci} / \mathrm{yr})$

\begin{tabular}{|c|c|c|c|c|c|c|c|c|c|}
\hline Nuclide & $\begin{array}{c}\text { Three Mile } \\
\text { Is land } 1 \\
\text { (Ref. 7) } \\
\end{array}$ & $\begin{array}{c}\text { Fort Calhoun } \\
(\operatorname{Ref} .4) \\
\end{array}$ & $\begin{array}{c}\text { Zion } 1 \& 2 \\
(\operatorname{Ref} .5) \\
\end{array}$ & $\begin{array}{l}\text { Turkey } \\
\text { Point } \\
3 \& 44 \\
\text { (Ref. 6) } \\
\end{array}$ & $\begin{array}{l}\text { Calvert } \\
\text { Cliffs } 1 \\
\text { (Ref. 7) }\end{array}$ & $\begin{array}{l}\text { Ginna } \\
\text { (Ref. 7) }\end{array}$ & $\begin{array}{l}\text { Prairie } \\
\text { Island } \\
1 \& 2 \\
\text { (Ref. } 42 \text { ) }\end{array}$ & $\begin{array}{c}\text { Rancho } \\
\text { Seco } \\
\text { (Ref. 43) }\end{array}$ & $\begin{array}{c}\text { Average } \\
(\mathrm{Ci} / \mathrm{yr}) / \mathrm{unit} \\
\end{array}$ \\
\hline $\begin{array}{l}\mathrm{Cr}-51 \\
\mathrm{Mn}-54 \\
\mathrm{Co}-57 \\
\mathrm{Co}-58 \\
\mathrm{Co}-60 \\
\mathrm{Fe}-59 \\
\mathrm{Zr}-95 \\
\mathrm{Nb}-95 \\
\mathrm{Ru}-103 \\
\mathrm{Ru}-106 \\
\mathrm{Sb}-125 \\
\mathrm{Cs}-134 \\
\mathrm{Cs}-136 \\
\mathrm{Cs}-137 \\
\mathrm{Ba}-140 \\
\mathrm{Ce}-141\end{array}$ & $\begin{array}{c}1.4(-3) \\
1.1(-4) \\
N A \\
1.1(-3) \\
2.0(-4) \\
2.3(-4) \\
2.7(-4) \\
1.4(-4) \\
9.1(-5) \\
N A \\
\text { NA } \\
8.0(-5) \\
\text { NA } \\
2.0(-4) \\
\text { NA } \\
1.5(-4)\end{array}$ & $\begin{array}{l}\text { ND } \\
\text { NA } \\
\text { NA } \\
2.0(-3) \\
2.7(-4) \\
\text { ND } \\
\text { ND } \\
\text { ND } \\
\text { ND } \\
\text { ND } \\
\text { NA } \\
1.6(-3) \\
\text { ND } \\
1.8(-3) \\
\text { ND } \\
\text { ND }\end{array}$ & $\begin{array}{l}\text { NA } \\
\text { NA } \\
\text { NA } \\
\text { NA } \\
\text { NA } \\
\text { ND } \\
\text { ND } \\
\text { ND } \\
\text { NA } \\
\text { NA } \\
\text { NA } \\
\text { NA } \\
\text { NA } \\
\text { NA } \\
\text { ND } \\
\text { NA }\end{array}$ & $\begin{array}{c}\text { ND } \\
6.3(-5) \\
\text { NA } \\
1.1(-3) \\
6.0(-4) \\
\text { ND } \\
\text { ND } \\
\text { ND } \\
\text { ND } \\
\text { ND } \\
\text { NA } \\
7.9(-4) \\
\text { ND } \\
1.4(-3) \\
\text { ND } \\
\text { ND }\end{array}$ & $\begin{array}{c}\text { NA } \\
3.0(-4) \\
\text { NA } \\
4.8(-4) \\
2.0(-3) \\
\text { NA } \\
7.9(-3) \\
\text { NA } \\
\text { NA } \\
\text { NA } \\
\text { NA } \\
2.0(-3) \\
\text { NA } \\
1.9(-3) \\
\text { NA } \\
\text { NA }\end{array}$ & $\begin{array}{l}1.9(-4) \\
6.7(-5) \\
N A \\
6.3(-4) \\
7.7(-4) \\
1.9(-5) \\
4.1(-5) \\
6.0(-5) \\
6.9(-5) \\
2.4(-5) \\
N A \\
3.4(-4) \\
1.9(-4) \\
1.1(-3) \\
1.6(-3) \\
2.8(-5)\end{array}$ & $\begin{array}{c}N A \\
2.7(-6) \\
N A \\
4.0(-5) \\
4.5(-5) \\
N A \\
5.7(-6) \\
1.0(-5) \\
2.7(-6) \\
N A \\
7.7(-6) \\
1.5(-6) \\
N A \\
9.4(-6) \\
N A \\
1.5(-6)\end{array}$ & $\begin{array}{c}\text { NA } \\
\text { NA } \\
\text { NA } \\
1.2(-2) \\
7.3(-4) \\
\text { NA } \\
\text { NA } \\
\text { NA } \\
\text { NA } \\
\text { NA } \\
\text { NA } \\
5.2(-5) \\
\text { NA } \\
8.0(-5) \\
\text { NA } \\
\text { NA }\end{array}$ & $\begin{array}{l}3.2(-4) \\
7.8(-5) \\
\text { NA } \\
1.9(-3) \\
5.1(-4) \\
5.0(-5) \\
1.0(-3) \\
3.0(-5) \\
2.3(-5) \\
6.0(-6) \\
3.9(-6) \\
5.4(-4) \\
4.8(-5) \\
7.2(-4) \\
4.0(-4) \\
2.6(-5)\end{array}$ \\
\hline
\end{tabular}

ND $=$ Not detected. For averaging purposes, a value of zero was assumed.

$N A=$ Not analyzed (or no measurement taken); plants not included in averaging.

Measurements were made downstream of the auxiliary building HEPA filter. Due to uncertainty in the DF's of the HEPA filter, the data is not considered. 
TABLE 2-20

MEASURED RELEASES UPSTREAM OF HEPA FILTERS - FUEL POOL AREA

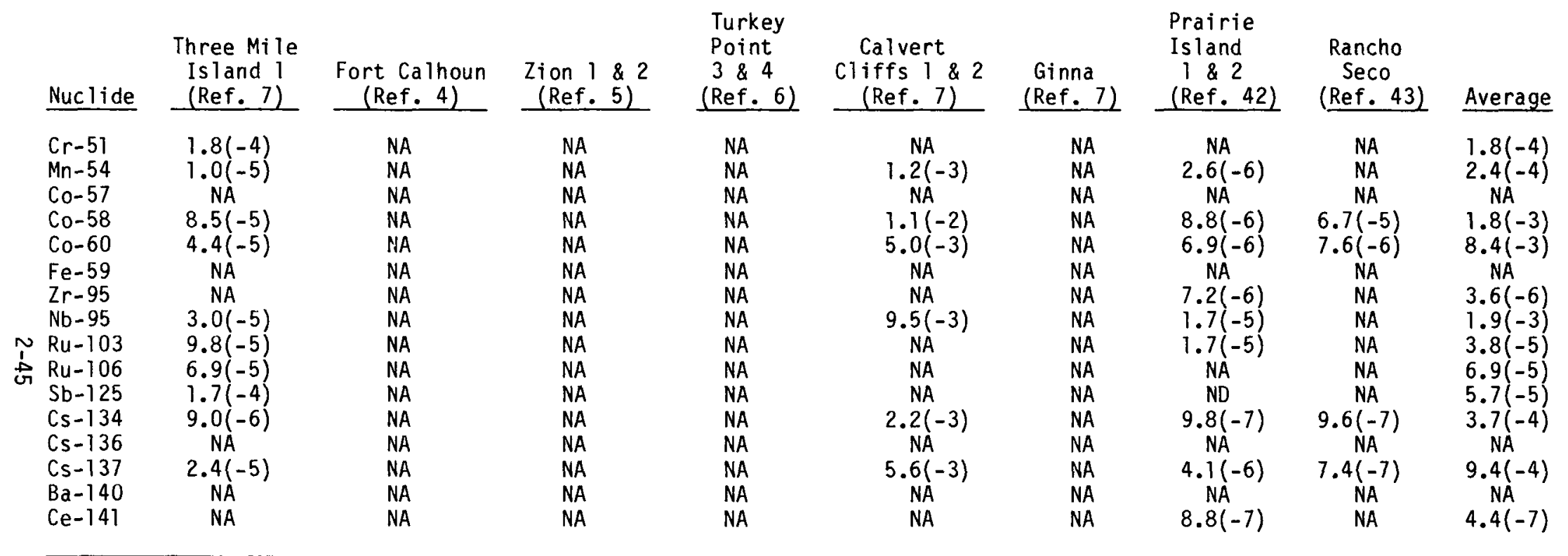

ND = Not detected. For averaging purposes, a value of zero was assumed.

NA = Not analyzed (or no measurement taken); plants not included in averaging. 
TABLE 2-21

MEASURED RELEASES UPSTREAM OF HEPA FILTERS - WASTE GAS SYSTEM

\begin{tabular}{|c|c|c|c|c|c|c|c|c|c|}
\hline Nuclide & $\begin{array}{l}\text { Three Mile } \\
\text { Island } \\
\text { (Ref. 7) } \\
\end{array}$ & $\begin{array}{c}\text { Fort Calhoun } \\
(\operatorname{Ref.4)} \\
\end{array}$ & $\begin{array}{c}\text { Zion } 1 \& 2 \\
\text { (Ref. 5) } \\
\end{array}$ & $\begin{array}{c}\text { Turkey } \\
\text { Point } \\
3 \text { \& } 4 \\
\text { (Ref. 6) } \\
\end{array}$ & $\begin{array}{l}\text { Calvert } \\
\text { Cliffs } 1 \\
\text { (Ref. } 7 \text { ) }\end{array}$ & $\begin{array}{l}\text { Ginna } \\
\text { (Ref. 7) } \\
\end{array}$ & $\begin{array}{l}\text { Prairie } \\
\text { Is land } \\
1 \& 2 \\
\text { (Ref.42) }\end{array}$ & $\begin{array}{c}\text { Rancho } \\
\text { Seco } \\
\text { (Ref. 43) } \\
\end{array}$ & $\begin{array}{c}\text { Average } \\
(\mathrm{C} i / \mathrm{yr}) / \text { unit } \\
\end{array}$ \\
\hline $\begin{array}{l}\mathrm{Cr}-51 \\
\mathrm{Mn}-54 \\
\mathrm{Co}-57 \\
\mathrm{Co}-58 \\
\mathrm{Co}-60 \\
\mathrm{Fe}-59 \\
\mathrm{Zr}-95 \\
\mathrm{Nb}-95 \\
\mathrm{Ru}-103 \\
\mathrm{Ru}-106 \\
\mathrm{Sb}-125 \\
\mathrm{Cs}-134 \\
\mathrm{Cs}-136 \\
\mathrm{Cs}-137 \\
\mathrm{Ba}-140 \\
\mathrm{Ce}-141\end{array}$ & $\begin{array}{l}8.4(-5) \\
1.1(-5) \\
N A \\
4.5(-5) \\
8.0(-5) \\
7.2(-6) \\
1.9(-5) \\
2.2(-5) \\
1.9(-5) \\
1.6(-5) \\
N A \\
1.2(-4) \\
3.2(-5) \\
3.5(-4) \\
1.4(-4) \\
1.3(-5)\end{array}$ & $\begin{array}{l}\text { ND } \\
\text { ND } \\
\text { NA } \\
3.8(-6) \\
\text { NA } \\
1.8(-6) \\
\text { ND } \\
\text { ND } \\
\text { ND } \\
\text { ND } \\
\text { NA } \\
1.2(-6) \\
\text { ND } \\
\text { NA } \\
\text { ND } \\
\text { ND }\end{array}$ & $\begin{array}{l}\text { ND } \\
4.0(-6) \\
\text { NA } \\
1.1(-5) \\
3.2(-6) \\
1.9(-6) \\
\text { ND } \\
\text { ND } \\
\text { ND } \\
\text { ND } \\
\text { NA } \\
1.1(-4) \\
\text { ND } \\
1.1(-4) \\
\text { ND } \\
\text { ND }\end{array}$ & $\begin{array}{l}\text { ND } \\
\text { ND } \\
\text { NA } \\
8.8(-7) \\
2.9(-7) \\
\text { ND } \\
\text { NA } \\
\text { ND } \\
\text { ND } \\
\text { ND } \\
\text { NA } \\
3.8(-8) \\
\text { ND } \\
8.8(-8) \\
\text { ND } \\
\text { ND }\end{array}$ & $\begin{array}{l}\text { NA } \\
\text { NA } \\
\text { NA } \\
\text { NA } \\
\text { NA } \\
\text { NA } \\
\text { NA } \\
\text { NA } \\
\text { NA } \\
\text { NA } \\
\text { NA } \\
\text { NA } \\
\text { NA } \\
\text { NA } \\
\text { NA } \\
\text { NA }\end{array}$ & $\begin{array}{l}\text { NA } \\
\text { NA } \\
\text { NA } \\
\text { NA } \\
\text { NA } \\
\text { NA } \\
\text { NA } \\
\text { NA } \\
\text { NA } \\
\text { NA } \\
\text { NA } \\
\text { NA } \\
\text { NA } \\
\text { NA } \\
\text { NA } \\
\text { NA }\end{array}$ & $\begin{array}{l}\text { NA } \\
N A \\
N A \\
N A \\
N A \\
N A \\
N A \\
N A \\
N A \\
N A \\
N A \\
N A \\
N A \\
N A \\
N A \\
\text { NA }\end{array}$ & $\begin{array}{c}\text { NA } \\
8.4(-9) \\
\text { NA } \\
5.1(-8) \\
5.9(-8) \\
\text { NA } \\
\text { NA } \\
\text { NA } \\
\text { NA } \\
\text { NA } \\
\text { NA } \\
1.1(-8) \\
\text { NA } \\
2.6(-8) \\
\text { NA } \\
\text { NA }\end{array}$ & $\begin{array}{c}1.4(-5) \\
2.1(-6) \\
N A \\
8.7(-6) \\
1.4(-5) \\
1.8(-6) \\
4.8(-6) \\
3.7(-6) \\
3.2(-6) \\
2.7(-6) \\
N A \\
3.3(-5) \\
5.3(-6) \\
7.7(-5) \\
2.3(-5) \\
2.2(-6)\end{array}$ \\
\hline
\end{tabular}

ND = Not detected. For averaging purposes, a value of zero was assumed.

$N A=$ Not analyzed (or no measurement taken); plants not included in averaging. 
Ginna

$$
\frac{2 \times 10^{8}{ }_{\mu} \mathrm{Ci}}{(5.3 \text { day/0.693) }}=2.6 \times 10^{7}{ }_{\mu} \mathrm{Ci} / \text { day } \mathrm{Xe-133} \text { leakage }
$$

Based on the xenon-133 concentration during power operation (Ref. 29) and the masses of primary coolant of the two plants, the fraction of the xenon-133 inventory in the containment released per day is

Maine Yankee

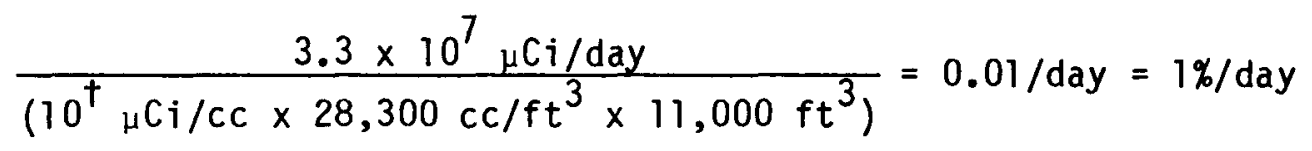

Ginna

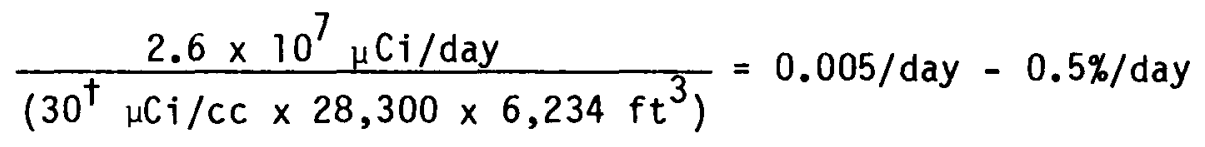

Reference 16 also contains data for the xenon-133 concentration in the containment atmosphere and the primary coolant at Yankee Rowe for the periods August-0ctober 1971, December 1971 - January 1972 and August-November 1973. These periods encompass several shutdowns and a wide variety of operating conditions, and during these periods the xenon concentration in the containment and in the primary coolant varied by two orders of magnitude. The percent of xenon-133 inventory in the coolant released to the containment atmosphere varied from approximately $0.05 \%$ /day to $0.5 \%$ /day. Also from Ref. 43 , this percent was determined to be 10.4 for Rancho Seco.

On the basis of these data, we consider that $3 \%$ /day of the noble gas inventory in the primary coolant is released to the containment atmosphere.

In the auxiliary building, the source term calculation is based on an assumed primary coolant leakage rate of 160 1b/day (20 gal/day). In the absence of available data, this value is based on engineering judgment and is consistent with values proposed in Environmental Reports.

The reactor coolant concentrations for $\mathrm{Xe}-133$ are measured values during 12/73 - 6/74 for Main Yankee and September and October of 1971' for Ginna (Ref. 16). 
In the turbine building, it is assumed that steam will leak to the turbine building atmosphere at a rate of $1700 \mathrm{lb} / \mathrm{hr}$. The leakage is considered to be from many sources, each too small to be detected individually, but which, taken collectively, total $17001 \mathrm{~b} / \mathrm{hr}$. The most significant leakage pathway is considered to be leakage through valve stem packings.

\subsubsection{STEAM GENERATOR BLOWDOWN FLASH TANK VENT}

\subsubsection{Parameter}

1. Pressurized water reactors, with U-tube steam generators, that are currentily under design, either direct their blowdown through a heat exchanger to cool the blowdown or, if a flash tank is used, vent the flash tank to a flash tank vent condenser or the main condenser. For these plants, iodine releases by this path are negligible and a partition factor of zero is used for the steam generator blowdown flash tank vent.

2. For older plants which still utilize flash tanks which vent directly to the atmosphere an iodine partition factor of 0.05 is used.

\subsubsection{Bases}

Approximately one-third of the blowdown stream flashes to steam in the flash tank, provided there is a heat balance between steam generator operating conditions $\left(550^{\circ} \mathrm{F}, 1000 \mathrm{psia}\right)$ and the blowdown flash tank conditions $\left(240^{\circ} \mathrm{F}\right.$, sat.). Although the iodine species in the blowdown stream will be predominantly nonvolatile (volatile species are degassed in the steam generator), significant iodine removal will occur because of entrainment by the flashing steam. A steam quality of $85 \%$ is considered in the evaluation. For currently designed PWR's which have provisions to prevent flashing (cooling blowdown below $212^{\circ} \mathrm{F}$ ) or to condense the steam leaving the flash tank, the entrainment losses will be negligible, i.e., a partition factor of zero.

\subsubsection{IODINE RELEASES FROM MAIN CONDENSER AIR EJECTOR EXHAUST}

\subsubsection{Parameter}

The iodine releases from the main condenser air ejector exhaust prior to treatment are calculated by the PWR-GALE Code using the data in Tables 2-2 through 2-8, and in Table 2-22.

\subsubsection{Bases}

The iodine releases from the main condenser air ejector exhaust are based on secondary side measurements made by EPRI at Point Beach 2, (Ref. 7), by EG\&G Idaho, Inc., for the NRC, at Turkey Point 3 and 4 (Ref. 6), and by Westinghouse at Point Beach 1 (Ref. 12) and Haddam Neck (Ref. 38). 
ANNUAL IODINE NORMALIZED RELEASES

FROM MAIN CONDENSER AIR EJECTOR EXHAUST*

\section{Data Source}

Turkey Point 3/4 (Ref. 6)

Point Peach $1 / 2$ (Ref. 7, 12)

Haddam Neck (Ref. 38)
Normalized Release

$(\mathrm{Ci} / \mathrm{yr} / \mu \mathrm{Ci} / \mathrm{g})$

$3.5(+3)$

$6.1(+2)$

$3.0(+1)$

$1.7(+3)$

Average

* The normalized release rate represents the effective release rate for radioiodine. It is the combination of the steam flow to the main condenser, the partitioning of radioiodine between the main condenser and the air ejector exhaust where it is measured and the partition coefficient for radioiodine from water to steam in the steam generator. 
In a manner similar to the discussion of normalized releases for building ventilation releases in Section 2.2.4, the main condenser air ejector exhaust iodine releases are directly related to the secondary coolant iodine-131 concentration. Therefore, for the air ejector exhaust, the normalized iodine release, $R_{N}$, is determined using the following expression:

$$
R_{N}=\frac{R_{A}}{C_{R W} \times P C}
$$

where

$$
\begin{aligned}
R_{N}= & \text { normalized effective release rate of iodine }-131, \mathrm{Ci} / \mathrm{yr} / \mu \mathrm{Ci} / \mathrm{g} \\
R_{A}= & \text { measured (absolute) iodine-131 release rate, } \mathrm{C} i / \mathrm{yr} \\
C_{R W}= & \text { measured secondary coolant iodine-131 concentration, } \mu \mathrm{Ci} / \mathrm{g} \\
\mathrm{PC}= & \text { measured iodine partition coefficient from secondary coolant } \\
& \text { water to steam in the steam generator. }
\end{aligned}
$$

Data on normalized release rates from the main condenser air ejector exhaust are given in Table 2-22. To obtain the release in curies/year from the air ejector exhaust of a particular PWR, the normalized release data in Table 2-22 are multiplied in the PWR-GALE Code by the iodine concentration in the secondary coolant water and the iodine partition coefficient from the water to steam for that particular PWR using the following expression:

$$
R_{\text {PWR }}=R_{N} \times C_{\text {PWRi }} \times P C_{\text {PWR }}
$$

where

$$
\begin{aligned}
& \begin{aligned}
R_{\text {PWRi }}= & \begin{array}{l}
\text { calculated annual release for particular PWR for iodine } \\
\text { isotope } i, \mathrm{C} i / y r
\end{array}
\end{aligned}
\end{aligned}
$$

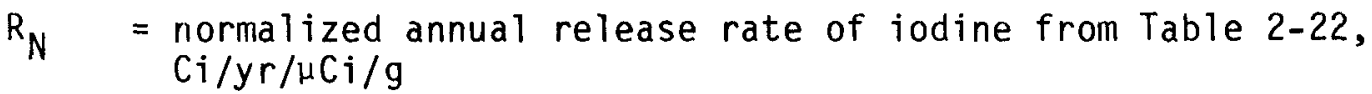

$$
\begin{aligned}
& C_{\text {PWRi }}=\text { calculated secondary coolant concentration for particular } \\
& \text { PWR for iodine isotope } \mathrm{i}, \mu \mathrm{Ci} / \mathrm{g} \\
& \begin{aligned}
P C_{P W R}= & \text { Iodine partition coefficient from water to steam in the } \\
& \text { steam generator for the particular PWR (see Table 2-6) }
\end{aligned}
\end{aligned}
$$


As discussed in references 6 and 7 , most of the iodine in the secondary system is not available for release to the main condenser air ejector exhaust due to iodine bypassing the condenser hotwell in the moisture separator/reheater drains and extraction steam, and possibly due to iodine plating out in the moisture separator/reheater, turbine and main condenser. As a result, the iodine release from the ma in condenser air ejector exhaust is small compared to the building ventilation releases.

\subsubsection{CONTAINMENT PURGE FREQUENCY}

\subsubsection{Parameter}

For those plants equipped with small diameter purge lines (diameter of about 8 inches or less), releases are based on continuous ventilation during power operation and on 2 purges per year at cold shutdown with the large containment purge lines. The continuous ventilation rate used in the evaluation is based on the applicant's design.

For older plants (those under review for operating licenses or those for which the construction permit SER was issued prior to July 1, 1975) not equipped with small diameter purge lines, releases are based on 2 purges per year at cold shutdown and 22 purges per year during power operation. The 22 purges consider the effect of use of large containment purge lines and of separate vent lines, if any. If, for a specific plant, there is filtration on the large purge lines but not on the vent lines, an additional GALE Code run will be made to account for the effect of the vent.

Operating experience and special design features (for example, little or no air operated equipment in the containment) to reduce the frequency of containment purging will be considered on a case-by-case basis.

\subsubsection{Bases}

It is assumed that the containment building is purged twice a year for refueling and maintenance. The two purges are considered for cold shutdowns for annual fuel loading and planned maintenance. In addition, experience at operating reactors (Table $2-23$ ) has indicated a need to purge or vent the containment frequently during full power operation and hot standby to control the containment pressure, temperature, humidity, and airborne activity levels (Ref. 17). For the above reasons, new plant designs are to include the capability to purge the containment continuously through smal1-diameter purge lines (about 8 inches in diameter) and only use the large containment purge lines at cold shutdowns and refueling outages (Ref. 18). On this basis, source term calculations for new plants should consider a continuous ventilation rate based on the applicant's containment design, along with the two cold shutdown purges per year with the large containment purge lines, unless special provisions are made to eliminate or reduce the need for continuous ventilation flow. 


\section{Yankee Rowe}

Purge and vent only after cooldown following shutdown

Reasons: Routinely pressurize containment for leak detection system

Duration: 2 to 6 hours

Maine Yankee

Purge once per quarter

Reason: Bring activity down

Duration: 2 to 3 days each quarter

Indian Point 2

Vent 2 times each day

Reason: Pressure balance control

Duration: Approximately 1 to 2 hours

Purge once every 2 weeks (duration not stated)

Three Mile Island 1

Purge approximately once per week during operation, always purge prior to shutdown

Reason: Improve temperature and humidity conditions

Duration: Approximately 48 hours

\section{Connecticut Yankee}

Purge - Cannot purge during operation, only during shutdown

Reason: Primarily to remove activity

Duration: 1 to 2 days

San Onofre 1

Purge each cooldown approximately 4 times per year, no purging during power operation

Purge for at least 24 hours, ventilate during entire shutdown period

Oconee 1

Continuous purge from startup through $7 / 1 / 74$

Purged twice since $7 / 1 / 74$, once on $7 / 8 / 74$ for several days and again on $8 / 22 / 74$ for 1 to 2 days

Reason: Reduction of gaseous activity for maintenance, etc. 
Oconee 2

Continuous purge since startup, lowest purge rate approximately $20,000 \mathrm{ft}^{3} / \mathrm{min}$

Reason: Reduction of gaseous activity for maintenance, etc.

Robinson 2

Purge approximately 20 times per year for 2 minutes each purge for testing of purge valves. In addition, purge approximately 10 times per year for an average of 100 hours each purge for personnel comfort reasons.

Vent about 75 times per year for about four hours each. Venting occurs to control containment pressure and to bring containment pressure to zero gauge prior to purging as noted above.

Turkey Point 3

For period $1 / 1 / 74$ to $7 / 1 / 74$

$\begin{array}{lc}\text { Total purges } & 14 \\ \text { Total time } & 502 \text { hours* } \\ \text { Maximum duration (1 purge) } & 253 \text { hours } \\ \text { Minimum duration (1 purge) } & 3 \text { hours } \\ \text { Infrequent purges or vents of } 10 \text { minutes for pressure control. }\end{array}$

Turkey Point 4

For period $1 / 1 / 74$ to $7 / 1 / 74$

$\begin{array}{ll}\text { Total purges } & 5 \\ \text { Total time } & 984 \text { hours* } \\ \text { Maximum time (1 purge) } & 742 \text { hours } \\ \text { Minimum time (1 purge) } & 5 \text { hours }\end{array}$

Surry 1 and 2

Containment operates at negative pressure. Discharge from vacuum pumps through filters to stack. During cold shutdown, there is continuous purging of containment.

Prairie Island

Frequency: Once per week for about 8 hours

Reason: To relieve pressure buildup due to instrument air leakage to containment 
TABLE 2-23 (continued)

PWR CONTAINMENT PURGING AND VENTING EXPERIENCE (REF. 17)

\section{Kewaunee}

Frequency: 5 times in 60 days usually for less than 1 hour, longer if for personnel entry.

Reason: Pressure control. During the 60-day period, purging occurred for personnel entry.

\section{Point Beach}

Continuous venting through a monitoring line at about $10 \mathrm{ft}^{3} / \mathrm{min}$ flow. Gas filtered on way to stack.

\section{Palidades}

One per week for about 10 minutes duration (planned upon resumption of power operation)

Reason: $\quad$ To control pressure buildups

Zion

Venting for pressure buildup about twice per week depending on outside temperature. Ranges from twice per day to once every two weeks.

Purges to control environment range from once per day to once every two weeks.

Duration: $3 / 4$ hour on venting; $3-4$ hours on purging.

Fort Calhoun**

For periods from $1 / 1 / 76$ to $6 / 31 / 76$ and $5 / 5 / 77$ to $12 / 31 / 77$.

Average of 65 purges per year with an average duration of about 20 hours.

\section{Millstone $2 * \star$}

For period from $7 / 1 / 75$ through $12 / 31 / 77$.

About 45 purges per year with an average duration of about 9 hours.

* Generally, long purges occur during plant outages while at cold shutdown conditions.

** Data for these plants was obtained from the Semi-annual Release Reports for the plants for the period indicated. 
For older plants (those under review for operating licenses or those for which the construction permit SER was issued prior to July 1, 1975) (Ref. 18) not equipped with small diameter purge lines, frequent periodic purges or vents will be used to control the above parameters (Ref. 18). A frequency of 22 purges per year during power operation is considered representative of plant operating experience for the combined effects of purging and venting.

\subsubsection{CONTAINMENT INTERNAL CLEANUP SYSTEM}

\subsubsection{Parameter}

Assume the internal cleanup system will operate for 16 hours prior to purging, that it provides a DF for radioiodine removal on charcoal adsorbers corresponding to the values in Table 1-5, and a DF of 100 for particulate removal on HEPA filters and that there is a containment air mixing efficiency of $70 \%$.

\subsubsection{Bases}

Internal cleanup systems may be used to reduce airborne iodine concentrations in the containment air prior to purging. Such systems normally recirculate containment air through HEPA filters and charcoal adsorbers to effect iodine and particulare removal. For source term calculations, it is assumed that the cleanup systems are operated for 16 hours prior to purging. It is considered that charcoal adsorbers provide a DF for iodine corresponding to the values in Table 1-5, that HEPA filters provide a DF of 100 for particulates, and that the containment air mixing efficiency is $70 \%$. The system operation time of 16 hours considers that two shifts will elapse following a decision to enter the containment. The time period of two shifts is a reasonable amount of time for pre-entry preparations.

A $70 \%$ mixing efficiency, based on data from the Ginna Station containment building atmosphere test conducted in 1971 (Ref. 19), is used in evaluations. Data from Reference 19 are

\begin{tabular}{lcll}
\multicolumn{1}{c}{ Parameter } & Symbol & & Value \\
\cline { 1 - 2 } $\begin{array}{l}\text { Length of test run } \\
\text { Initial iodine activity }\end{array}$ & $A_{0}$ & & 6 hours \\
Final iodine activity & $A^{-2}$ & $1.2 \times 10^{-8} \mu \mathrm{Ci} / \mathrm{cc}$ \\
$\begin{array}{l}\text { Containment volume } \\
\begin{array}{l}\text { Internal recirculation } \\
\text { system flow rate }\end{array}\end{array}$ & $\mathrm{V}$ & $10^{6} \mathrm{ft}^{3}$ \\
& & $6.1 \times 10^{5} \mathrm{ft}^{3} / \mathrm{hr}$
\end{tabular}


The efficiency of iodine removal, E, can be estimated from

$$
\frac{A_{0}}{A}=\exp \left(\frac{F E T}{V}\right)
$$

Substituting Ginna data into the equation

$$
\begin{aligned}
\frac{1 \times 10^{-8}}{1 \times 10^{-9}} & =\exp \left[\left(6.1 \times 10^{5}\right)(E)(6) /\left(10^{6}\right)\right] \\
10 & =\exp (3.7 E), \text { therefore } E=0.63 .
\end{aligned}
$$

The iodine removal efficiency $E$ is a function of filter efficiency, $E_{a}$, and mixing efficiency, $E_{m}$.

$$
E=E_{a} E_{m}=0.63
$$

In calculating $E_{m}$ we used the assumed DF of 10 for charcoal derived from Table $1-5$, (90\% removal). Using $E_{a}$ equal to $0.9, E_{m}$ is calculated to be $70 \%$.

$$
E_{m}=E / E_{a}=0.63 / 0.9=0.7
$$

\subsubsection{RADIOIODINE REMOVAL EFFICIENCIES FOR CHARCOAL ADSORBERS AND} PARTICULATE REMOVAL EFFICIENCIES FOR HEPA FILTERS

\subsubsection{Parameter}

Use a removal efficiency of $99 \%$ for particulate removal by HEPA filtration. For charcoal adsorbers, which satisfy the guideline of Reg. Guide 1.140 (Rev. 2), removal efficiencies for all forms of radioiodine are as follows:

\section{Activated Carbon Bed Depth ${ }^{\mathrm{a}}$}

2 inches. Air filtration system designed to operate inside primary containment.

2 inches. Air filtration system designed to operate outside the primary containment and relative humidity is controlled to $70 \%$.
Removal Efficiencies

For Radioiodine(\%)
90

70

a Multiple beds, e.g., two 2 -inch beds in series, should be treated as single bed of aggregate depth of 4 inches. 


\section{Activated Carbon Bed Depth ${ }^{a}$}

4 inches. Air filtration system designed to operate outside the primary containment and relative humidity is controlled to $70 \%$.

6 inches. Air filtration system designed to operate outside the primary containment and relative humidity is controlled to $70 \%$.
Removal Efficiencies For Radioiodine (\%)

90

99

\section{2 .11 .2 Bases}

The removal efficiencies assigned to HEPA filters for particulate removal and charcoal adsorbers for radioiodine removal are based on the design, testing and maintenance criteria recommended in Regulatory Guide 1.140, "Design, Testing and Maintenance Criteria for Normal Ventilation Exhaust System Air Filtration and Adsorption Units of Light-Water-Cooled Nuclear Power Plants" (Ref. 2).

\subsubsection{WASTE GAS SYSTEM INPUT FLOW TO PRESSURIZED STORAGE TANKS}

\subsubsection{Parameter}

The input flow rate to the pressurized storage tanks is variable depending on the system design as can be seen from Table 2-24 and 2-25. Therefore each applicant should supply the value of $F$, the waste gas system input flow to the pressurized storage tanks. If detailed design information is not available, the data given in Tables 2-24 and 2-25 may be used. These data show that the average waste gas input flow is $170 \mathrm{ft}^{3} /$ day (STP) per reactor for PWR's without recombiners and $30 \mathrm{ft}^{3} / \mathrm{day}^{2}$ (STP) per reactor for PWR's with recombiners.

\section{2 .12 .2 Bases}

As can be seen from Tables 2-24 and 2-25 there is variation among PWR system designs for the waste gas system input flow.

A review of the waste gas processing systems proposed for a number of PWR's as given in the respective PSAR's and FSAR's has yielded the design flow rates shown in Tables 2-24 and 2-25. Table 2-24 indicates that for reactors designed without recombiners to treat the gas prior to holdup in pressurized storage tanks, the average expected flow is approximately $170 \mathrm{ft}^{3} /$ day (STP) per reactor. Table 2-25 indicates that for reactors designed with recombiners to remove hydrogen prior to holdup in pressurized storage tanks, the average expected flow is approximately $30 \mathrm{ft}^{3} /$ day (STP) per reactor. 


Reactor

San Onofre $2 / 3$

Waterford 3

Pilgrim 2

St. Lucie $1 / 2$

Millistone 2

Arkansas 1/2

Byron $1 / 2$

Sequoyah $1 / 2$

Marble Hill 1/2

Diablo Canyon $1 / 2$

Trojan

Oconee $1 / 2 / 3$

Davis Besse 1

Bellefonte $1 / 2$
Net Flow per Reactor

$\mathrm{ft}^{3} /$ day
57
171
69
139
49
68

173

173

173

343

225

180

144

163

Average Net Flow for PWR's without recombiners

$=170 \mathrm{ft}^{3} /$ day (STP) per reactor 
TABLE 2-25

WASTE GAS SYSTEM INPUT FLOW TO PRESSURIZED STORAGE TANKS

FOR PWR'S WITH RECOMBINERS

\begin{tabular}{lc}
\multicolumn{1}{c}{ Reactor } & $\begin{array}{c}\text { Net Flow per Reactor } \\
\mathrm{ft}^{3} / \text { day (STP) }\end{array}$ \\
WPPSS 1 & 96 \\
Farley $1 / 2$ & 3 \\
McGuire $1 / 2$ & 18 \\
Average Net Flow for PWR's & $=30 \mathrm{ft}^{3} /$ day (STP) per reactor \\
with recombiners &
\end{tabular}

* Net flow rate is determined downstream of any recombiner (which is assumed $100 \%$ effective in removing hydrogen). 


\subsubsection{HOLDUP TIMES FOR CHARCOAL DELAY SYSTEMS}

\subsubsection{Parameter}

$$
\mathrm{T}=0.011 \mathrm{MK} / \mathrm{F}
$$

where

$T$ is the holdup time, in days; and

$K$ is the dynamic adsorption coefficient, in $\mathrm{cm}^{3} / \mathrm{g}$, (see chart below);

$M \quad$ is the mass of charcoal adsorber, in $10^{3}$ lbs;

$F \quad$ is the system flow rate, in $\mathrm{ft}^{3} / \mathrm{min}$;

0.011 is the factor to convert from $\left(10^{3} 1 \mathrm{~b} . \mathrm{cm}^{3} / \mathrm{g}\right) /\left(\mathrm{ft}^{3} / \mathrm{min}\right)$ to days.

Dynamic adsorption coefficients, $K$, (in $\mathrm{cm}^{3} / g$ ) are as follows:

\begin{tabular}{|c|c|c|c|}
\hline $\begin{array}{l}\text { Operating } 77^{\circ} \mathrm{F} \\
\text { Dew Point } 45^{\circ} \mathrm{F} \\
\end{array}$ & $\begin{array}{l}\text { Operating } 77^{\circ} \mathrm{F} \\
\text { Dew Point } 0^{\circ} \mathrm{F} \\
\end{array}$ & $\begin{array}{l}\text { Operating } 77^{\circ} \mathrm{F} \\
\text { Dew Point }-40^{\circ} \mathrm{F}\end{array}$ & $\begin{array}{l}\text { Operating } 0^{\circ} \mathrm{F} \\
\text { Dew Point }-20^{\circ} \mathrm{F}\end{array}$ \\
\hline 18.5 & 25 & 70 & 105 \\
\hline 330 & 440 & 1160 & 2410 \\
\hline
\end{tabular}

\subsubsection{Bases}

Charcoal delay systems are evaluated using the above equation and dynamic adsorption coefficients. $T=M K / F$ is a standard equation for the calculation of delay times in charcoal adsorption systems (Ref. 20). The dynamic adsorption coefficients ( $K$ values) for $X e$ and $\mathrm{Kr}$ are dependent on operating temperature and moisture content (Ref. 21 and 22) in the charcoal, as indicated by the values in the above parameter. The $K$ values represent a composite of data from operating reactor charcoal delay systems (Ref. 23 and 24) and reports concerning charcoal adsorption systems (Ref. 20-22, 24-27).

The factors influencing the selection of $K$ values are:

1. Operational data from KRB (Ref. 23) and from KWL (Ref. 24), and from Vermont Yankee (Ref. 28). 
2. The effect of temperature on the dynamic adsorption coefficients, indicated in Figure 2-3 (Ref. 21).

3. The effect of moisture on the dynamic adsorption coefficients, shown in Figure 2-4. The affinity of charcoal for moisture, shown in Figure 2-5.

4. The variation in $k$ values between researchers and between the types of charcoal used in these systems (Refs. 21 and 27). Because of the variation in $K$ values based on different types of charcoal and the data reported, average values taken from KRB and KWL data shown in Figure 2-3 are used.

The coefficient 0.011 adjusts the units and was calculated as follows:

$$
\begin{aligned}
& T \text { (days })=\frac{\left.M\left(10^{3} \mathrm{lbs}\right) \mathrm{K}\left(\mathrm{cm}^{3} / \mathrm{g}\right)(454 \mathrm{~g} / 1 \mathrm{~b}) 3.53 \times 10^{-5} \mathrm{ft}^{3} / \mathrm{cm}^{3}\right)}{\mathrm{F}\left(\mathrm{ft}^{3} / \mathrm{min}\right)(1440 \mathrm{~min} / \text { day })} \\
& T=0.011 \frac{\mathrm{MK}}{\mathrm{F}}
\end{aligned}
$$

\subsubsection{LIQUID WASTE INPUTS}

\subsubsection{Parameter}

The flow rates 1 isted in Table 2-26 are used as inputs to the liquid radwaste treatment system. Flows that cannot be standardized are added to those listed in Table 2-26 to fit an individual application, e.g., shim bleed and equipment leaks to the reactor coolant drain tank. Disposition of liquid streams to the appropriate collection tanks is based on the applicant's proposed method of processing.

\subsubsection{Bases}

The flow rates used represent average values for a plant operating at steady-state conditions. The values are derived from values proposed by the ANS 55.6 Working Group in proposed American National Standard, "Liquid Radioactive Waste Processing System for Light Water Reactor Plants," (Ref. 29) from operating and design data, and from information furnished by applicants in response to source term questions. Data from Zion (Ref. 5) indicate that the values for fraction of primary coolant activity given in Table 2-26 provide reasonable estimates of plant operating experience.

\subsubsection{DETERGENT WASTE}

\subsubsection{Parameters}

For plants with an onsite laundry, use the radionuclide distribution given in Table 2-27 for untreated detergent wastes. The quantities shown 


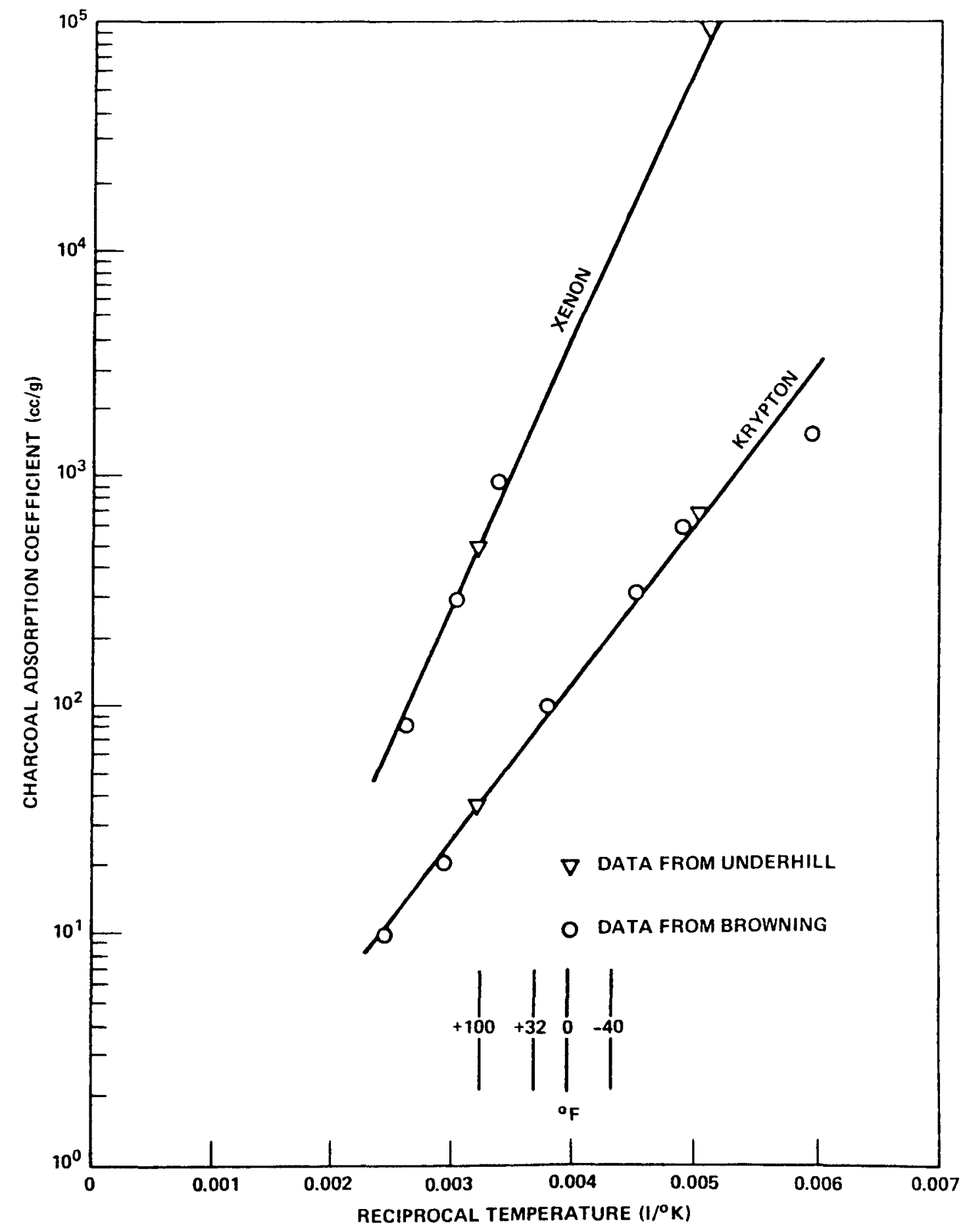

FIGURE 2-3 KRYPTON AND XENON K VALUES AS A FUNCTION OF RECIPAOCAL TEMPERATURE 


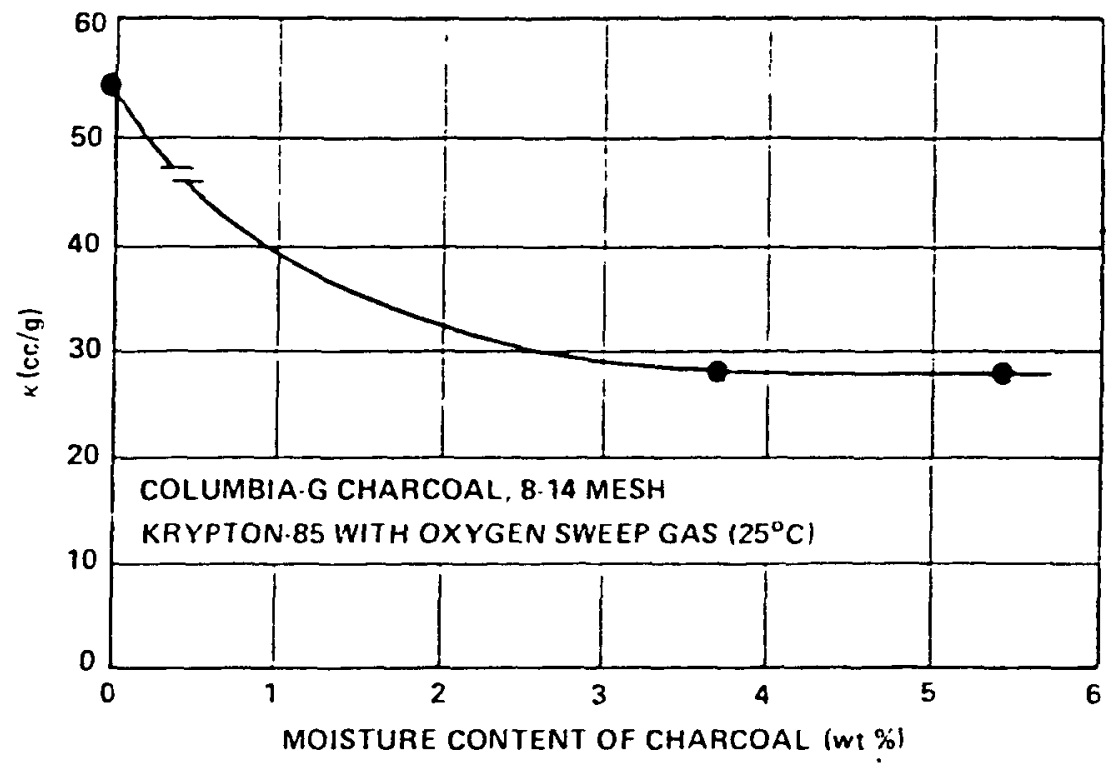

FIGURE 2-4 EFFECT OF MOISTURE CONTENT ON THE DYNAMIC ADSORPTION COEFFICIENT 


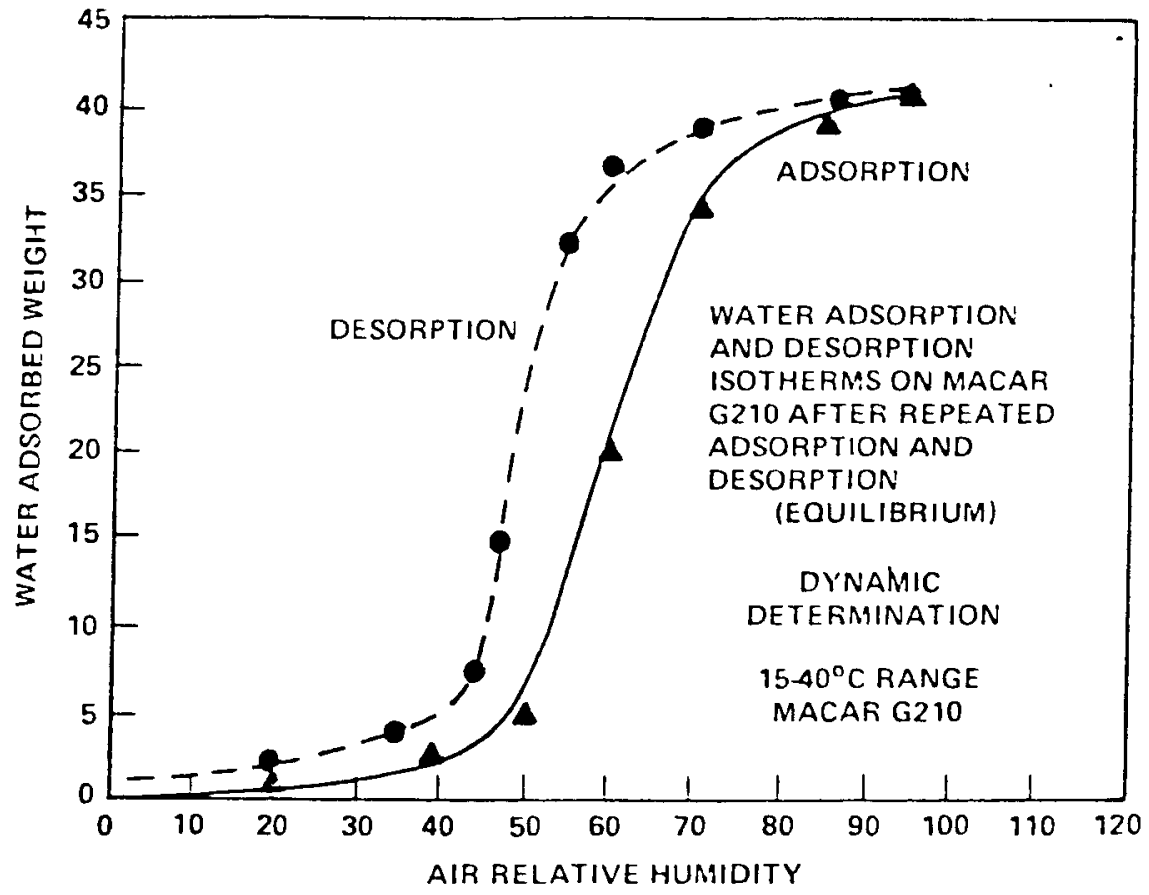

FIGURE 2.5 CHARCOAL MOISTURE AS A FUNCTION OF RELATIVE HUMIDITY 
TABLE $2-26$

PWR LIQUID WASTES

EXPECTED DAILY AVERAGE INPUT FLOW RATE (in Gal/day)

Type of treatment of blowdown recycled to secondary system (U-tube steam generator plants) or type of treatment of condensate (once-through steam generator plants

$\begin{array}{lcc} & \text { Deep-bed cond. } & \\ \begin{array}{l}\text { Deep-bed cond. } \\ \text { demineralizers }\end{array} & \begin{array}{c}\text { without } \\ \text { with ultrasonic }\end{array} & \text { ultrasonic } \\ \text { resincleaner } & \text { resincleaner } & \text { Filter- } \\ \text { remineralizer }\end{array}$

Plant with

blowdown treatment. Product not recycled to

condenser or secondary coolant system

FRACTION OF PRIMARY COOLANT ACTIVITY (PCA)

1. REACTOR CONTAINMENT

b. Primary coolant leakage, miscellaneous sources

c. Primary coolant equipment

2. PRIMARY COOLANT SYSTEMS (OUTSIDE OF CONTAINMENT)

a. Primary coolant system equipment drains

b. Spent fuel pit liner drains

c. Primary coolant sampling system drains

d. Auxiliary building floor 
TABLE 2-26 (Cont inued)

3. SECONDARY COOLANT SYSTEMS

\begin{tabular}{|c|c|c|c|c|c|c|}
\hline a. & $\begin{array}{l}\text { Secondary coolant sampling } \\
\text { system drains }\end{array}$ & 1400 & 1400 & 1400 & 1400 & $10^{-4}$ \\
\hline b. & $\begin{array}{l}\text { Condensate demineralizer } \\
\text { rinse and transfer } \\
\text { solutions }\end{array}$ & 3000 & 12000 & - & - & $10^{-8}$ \\
\hline c. & $\begin{array}{l}\text { Condensate demineralizer } \\
\text { regenerant solutions }\end{array}$ & 850 & 3400 & - & - & $\begin{array}{l}\text { Calculated in } \\
\text { GALE Code }\end{array}$ \\
\hline d. & $\begin{array}{l}\text { Uitrasonic resin cleaner } \\
\text { solutions }\end{array}$ & 15000 & - & - & - & $10^{-6}$ \\
\hline e. & $\begin{array}{l}\text { Condensate filter- } \\
\text { demineralizer backwash }\end{array}$ & - & - & 8100 & - & $2 \times 10^{-6}$ \\
\hline f. & Steam generator blowdown & - & - & - & Plant dependent ${ }^{\dagger \dagger}$ & Plant dependent ${ }^{\dagger}$ \\
\hline g. & $\begin{array}{l}\text { Turbine building floor } \\
\text { drains }\end{array}$ & 7200 & 7200 & 7200 & 7200 & $\begin{array}{l}\text { Calculated in } \\
\text { GALE Code }\end{array}$ \\
\hline
\end{tabular}

4. DETERGENT AND DECONTAMINATION SYSTEMS

a. On-site laundry facility

b. Hot showers

c. Hand wash sink drains

300

300

Negligible

200

Negligible

300

Negligible

200

200

200

d. Equipment and area

40

40

40

40

$\star \star$

$\star \star$

\section{9,700}

26,300

19,000

10,000

** GALE Code uses release data given in Table 2-27 to calculate releases from this source.

†† Input parameter

* About $40 \%$ of the leakage flashes, resulting in PCA fraction of the leakage greater than 1.0 . 


\section{CALCULATED ANNUAL RELEASE OF RADIOACTIVE MATERIALS}

\section{IN UNTREATED DETERGENT WASTE}

Nuclide

P-32

$\mathrm{Cr}-51$

$\mathrm{Mn}-54$

$\mathrm{Fe}-55$

$\mathrm{Fe}-59$

Co-58

Co-60

$\mathrm{Ni}-63$

$\mathrm{Sr}-89$

$\mathrm{Sr}-90$

$\mathrm{Y}-91$

$\mathrm{Zr}-95$

$\mathrm{Nb}-95$

Mo-99

$\mathrm{Ru}-103$

Ru-106

Ag-110m

$\mathrm{Sb}-124$

I- 131

Cs -134

Cs -136

Cs -137

$\mathrm{Ba}-140$

Ce-141

Ce-144
Ci/yr/reactor

$1.8(-4)$

$4.7(-3)$

$3.8(-3)$

$7.2(-3)$

$2.2(-3)$

$7.9(-3)$

$1.4(-2)$

$1.7(-3)$

$8.8(-5)$

$1.3(-5)$

$8.4(-5)$

$1.1(-3)$

$1.9(-3)$

$6(-5)$

2.9(-4)

$8.9(-3)$

$1.2(-3)$

4.3(-4)

$1.6(-3)$

$1.7(-2)$

$3.7(-4)$

$1.6(-2)$

$9.1(-4)$

$2.3(-4)$

$3.9(-3)$

$0.09 \mathrm{Ci}$ 
in Table 2-27 should be added to the adjusted liquid source term. Detergent waste releases should be reduced, using appropriate decontamination factors from this report if treatment is provided.

\section{2 .15 .2 Bases}

In the evaluation of liquid radwaste treatment systems, it is assumed that detergent wastes (laundry and personnel drains) will have the radionuclide distribution given in Table 2-27. The radionuclide distribution is based on measurements at four nuclear power plants, which are given in Table 2-28.

\subsubsection{CHEMICAL WASTES FROM REGENERATION OF CONDENSATE DEMINERAL IZERS}

\subsubsection{Parameter}

1. Liquid flows to demineralizer at main steam activity.

2. All nuclides removed from the secondary coolant by the demineralizers are removed from the resins during regeneration.

3. Use a regeneration cycle of 1.2 days times the number of demineralizers for deep bed condensate system without ultrasonic resin cleaner (URC); for systems using URC, use a regeneration cycle of 8 days times the number of demineralizers.

\subsubsection{Bases}

Operating data (Ref. 30, 31) from Arkansas Nuclear One-Unit 1 indicate that one condensate demineralizer (without URC) is chemically regenerated every 1.2 days. The 8 -day period for systems using URC is from Reference 29.

All material exchanged or filtered out by the resins between regenerations is contained in the regenerant waste streams, therefore, each regeneration will have approximately the same effectiveness (i.e., each regeneration removes all material collected since the previous regeneration, leaving a constant quantity of material on the resins after regeneration). Regeneration cycles are normally controlled by particulate buildup on resin beds, resulting in high pressure drops across the bed.

\subsubsection{TRITIUM RELEASES}

\subsubsection{Parameter}

The tritium releases through the combined liquid and vapor pathways are $0.4 \mathrm{Ci} / \mathrm{yr}$ per MWt. The quantity of tritium released through the liquid pathway is based on the calculated volume of liquid released, excluding secondary system wastes, with a primary coolant tritium concentration of $1.0 \mu \mathrm{Ci} / \mathrm{ml}$ up to a maximum of $90 \%$ of the total quantity of tritium calculated to be available for release. It is assumed that the remainder of the tritium produced is released as a gas from building 
TABLE 2-28

RADIONUCLIDE DISTRIBUTION OF DETERGENT WASTE

(millicuries/month)

\begin{tabular}{|c|c|c|c|c|}
\hline Nuclide & $\begin{array}{c}\text { Oyster } \\
\text { Creek } \\
(1971-1973) \\
(\text { Ref. } 41) \\
\end{array}$ & $\begin{array}{c}\text { Ginna } \\
(1972-1973) \\
(\operatorname{Ref.} 8) \\
\end{array}$ & $\begin{array}{c}\text { Zion* } \\
(1977) \\
\text { (Ref. 5) } \\
\end{array}$ & $\begin{array}{l}\text { Fort } \\
\text { Calhoun } \\
(1977) \\
\text { (Ref. } 4 \text { ) }\end{array}$ \\
\hline$P-32$ & $1.5(-2)$ & NA & NA & NA \\
\hline $\mathrm{Cr}-51$ & $2.3(-1)$ & NA & $9.4(-1)$ & NA \\
\hline$M n-54$ & 1.3 & $1.2(-1)$ & $1.6(-1)$ & $1.9(-2)$ \\
\hline $\mathrm{Fe}-55$ & $3.5(-1)$ & NA & 1.9 & $1.6(-1)$ \\
\hline $\mathrm{Fe}-59$ & $2.9(-1)$ & NA & $2.6(-1)$ & NA \\
\hline Co-58 & $3.5(-1)$ & $4.1(-1)$ & 2.4 & $1.5(-1)$ \\
\hline Co-60 & 3.8 & $9(-1)$ & $9.8(-1)$ & $3(-2)$ \\
\hline $\mathrm{Ni}-63$ & NA & NA' & $3.5(-1)$ & $7.1(-2)$ \\
\hline$S r-89$ & $2.1(-2)$ & NA & $7(-3)$ & $1.4(-3)$ \\
\hline$S r-90$ & $2.5(-3)$ & NA & $7.6(-4)$ & $N A$ \\
\hline$Y-91$ & NA & NA & $1.4(-2)$ & NA \\
\hline $\mathrm{Zr}-95$ & $8.3(-2)$ & $1.6(-1)$ & $1.4(-1)$ & NA \\
\hline $\mathrm{Nb}-95$ & $1.6(-1)$ & $2(-1)$ & $2.7(-1)$ & NA \\
\hline Mo-99 & $N A$ & $5(-3)$ & $N A$ & NA \\
\hline$R u-103$ & $1.3(-2)$ & $3.2(-2)$ & $5.2(-2)$ & NA \\
\hline$R u-106$ & NA & $7.4(-1)$ & $N A$ & NA \\
\hline $\mathrm{Ag}-110 \mathrm{~m}$ & NA & $1(-1)$ & NA & NA \\
\hline$S b-124$ & $6.1(-2)$ & NA & $4.7(-2)$ & NA \\
\hline $\mathrm{I}-131$ & $4.3(-1)$ & $5.5(-2)$ & $1.7(-1)$ & $1.7(-2)$ \\
\hline$C_{s-134}$ & $1.7(-1)$ & 1.4 & 1.5 & 1.4 \\
\hline Cs-136 & NA & NA & $6.2(-2)$ & NA \\
\hline$C_{s}-137$ & $2.9(-1)$ & 2.5 & 2.1 & 1.7 \\
\hline $\mathrm{Ba}-140$ & $7.6(-2)$ & NA & NA & NA \\
\hline $\mathrm{Ce}-141$ & $3.3(-2)$ & $5(-3)$ & NA & NA \\
\hline $\mathrm{Ce}-144$ & $7.3(-2)$ & $5.8(-1)$ & NA & NA \\
\hline TOTAL & 7.7 & 7.2 & 11.4 & 3.5 \\
\hline
\end{tabular}

Note: $\quad N A=$ radionuclides were not analyzed.

* For two units. 
ventilation exhaust systems. About eighty percent of the tritium in the gaseous effluents is released from the auxiliary building ventilation system, including the refueling area, and the remaining $20 \%$ of the tritium in gaseous effluents is released from the containment building ventilation system.

\subsubsection{Bases}

The release rate of $0.4 \mathrm{Ci} / \mathrm{yr} / \mathrm{MWt}$ is based on a review of the tritium release rates at a number of PWR's and on data from specific measurements of tritium inventory and tritium releases at the Ginna plant (Ref. 8). The measurements at Ginna were made during the first two core cycles during which the reactor operated 605 effective full power days. The observed tritium buildup during this period was $1410 \mathrm{Ci}$. For the same period, 910,000 MWd of thermal power were generated. Using these data, considering an $80 \%$ plant capacity factor and considering tritium decay, the annual average tritium release is

$$
\frac{1410 \mathrm{Ci}}{910,000 \mathrm{MWd}}(0.8)(365 \text { days } / \mathrm{yr}) \mathrm{e}^{-0.693(1) / 12.3}=0.43 \mathrm{Ci} / \mathrm{yr} \text { per MWt }
$$

Table 2-29 gives the reported liquid and gaseous tritium releases for 1972-1978 for thirty-five operating PWR's that use zircaloy clad fuel and started commercial operation before 1978. Table 2-29 shows these data expressed as the average release rate from the plants as a function of the number of years of operation of each plant. The tritium release rate from a PWR should reach a steady state value after a few years as a result of leakages from the plant. Table 2-30 illustrates the fact that the tritium release rate is approaching a steady state value of approximately $0.4 \mathrm{Ci} / \mathrm{yr} / \mathrm{MWt}$ which is the value obtained from the Ginna measurements. At steady state, the release rate from a plant is approximately equal to the amount entering the primary coolant since only about $5 \%$ per year of the plant tritium inventory will decay. Based on the data from Ginna and the data in Table 2-30 we will use a release rate of 0.4 $\mathrm{Ci} / \mathrm{yr} / \mathrm{MWt}$, which considers both liquid and vapor pathways.

The amount of tritium released via the liquid pathway is calculated from the volume of nrimary coolant that is released in the non recyclable waste streams for the boron recovery, clean waste, and dirty waste systems. The concentration of tritium in wastes originating from primary coolant is assumed to be $1 \mu \mathrm{Ci} / \mathrm{ml}$, consistent with the $\mathrm{N} 237$ source term. Tritium in liquid that leaks into, or is used as makeup to, the secondary system is considered to be released in liquid effluents through the turbine building floor drain discharge. The parameters for primary coolant activity prior to processing are used to calculate the tritium concentration in the waste streams.

Data in Table 2-31 indicate that tritium released in liquid effluents can make up a large fraction of the total tritium produced. Therefore we have considered that the tritium calculated to be released in liquid effluents is up to a maximum of $90 \%$ of the total quantity of tritium calculated to be available for release. 


\begin{tabular}{|c|c|c|}
\hline Reactor Name & $\begin{array}{c}\text { Power } \\
\text { per unit } \\
\text { MWt }\end{array}$ & $\begin{array}{c}\text { Startup } \\
\text { Date }\end{array}$ \\
\hline R. E. Ginna & 1520 & 1969 \\
\hline H. B. Robinson & 2200 & 1970 \\
\hline Point Beach $1 / 2$ & 1518 & $1970 / 72$ \\
\hline Palisades & 2530 & 1971 \\
\hline Maine Yankee & 2440 & 1972 \\
\hline Indian Point $2 / 3$ & 2758 & $1973 / 76$ \\
\hline Surry $1 / 2$ & 2441 & $1972 / 73$ \\
\hline Turkey Point $3 / 4$ & 2200 & $1972 / 73$ \\
\hline Oconee $1 / 2 / 3$ & 2568 & $1973 / 74 / 74$ \\
\hline Zion $1 / 2$ & 3250 & $1973 / 73$ \\
\hline Fort CaIhoun & 1420 & 1973 \\
\hline Prairie Island $1 / 2$ & 1650 & $1973 / 74$ \\
\hline Kewaunee & 1650 & 1974 \\
\hline Three Mile Island 1 & 2535 & 1974 \\
\hline Rancho Seco & 2772 & 1974 \\
\hline Arkansas 1 & 2568 & 1974 \\
\hline Calvert Cliffs $1 / 2$ & 2700 & $1974 / 76$ \\
\hline Cook 1 & 3250 & 1975 \\
\hline Millstone 2 & 2560 & 1975 \\
\hline Trojan & 3411 & 1975 \\
\hline St. Lucie 1 & 2560 & 1976 \\
\hline Beaver Valley 1 & 2652 & 1976 \\
\hline Salem 1 & 3338 & 1976 \\
\hline
\end{tabular}

Nuclear Thermal Output per unit $10^{6} \mathrm{MWDt}$ $\underline{1972}$

1973 $1974 \quad 1975 \quad 1976$ $\underline{1977}$

$\begin{array}{llllll}0.32 & 0.45 & 0.28 & 0.40 & 0.29 & 0.46\end{array}$

$0.62 \quad 0.51$

0.39

0.57

0.66

0.59

$0.42 \quad 0.77$

0.43

0.87

0.91

0.93

$\begin{array}{ll}0.24 & 0.27\end{array}$

0.02

0.37

0.40

0.72

0.48

0.61

0.81

0.69

0.48

0.69

0.56

1.46

0.80

1.21

1.05

1.08

1.16

1.12

1.27

0.51

1.95

1.65

1.13

1.37

1.29

1.67

0.28

0.30

1.53

0.94

0.86

0.39

0.45

0.45

1.03

0.73

0.58

0.46

0.17

0.29

0.73

0.64

0.50

0.75

0.58

0.84

0.68

0.90

1.24

0.63

0.64

0.31

0.59

0.88

0.73

0.42

0.28

* Data from semiannual reports of reactors listed. 
TABLE 2-29 (continued)

TRITIUM RELEASE DATA FROM OPERATING PWR'S WITH ZIRCALOY-CLAD FUELS*

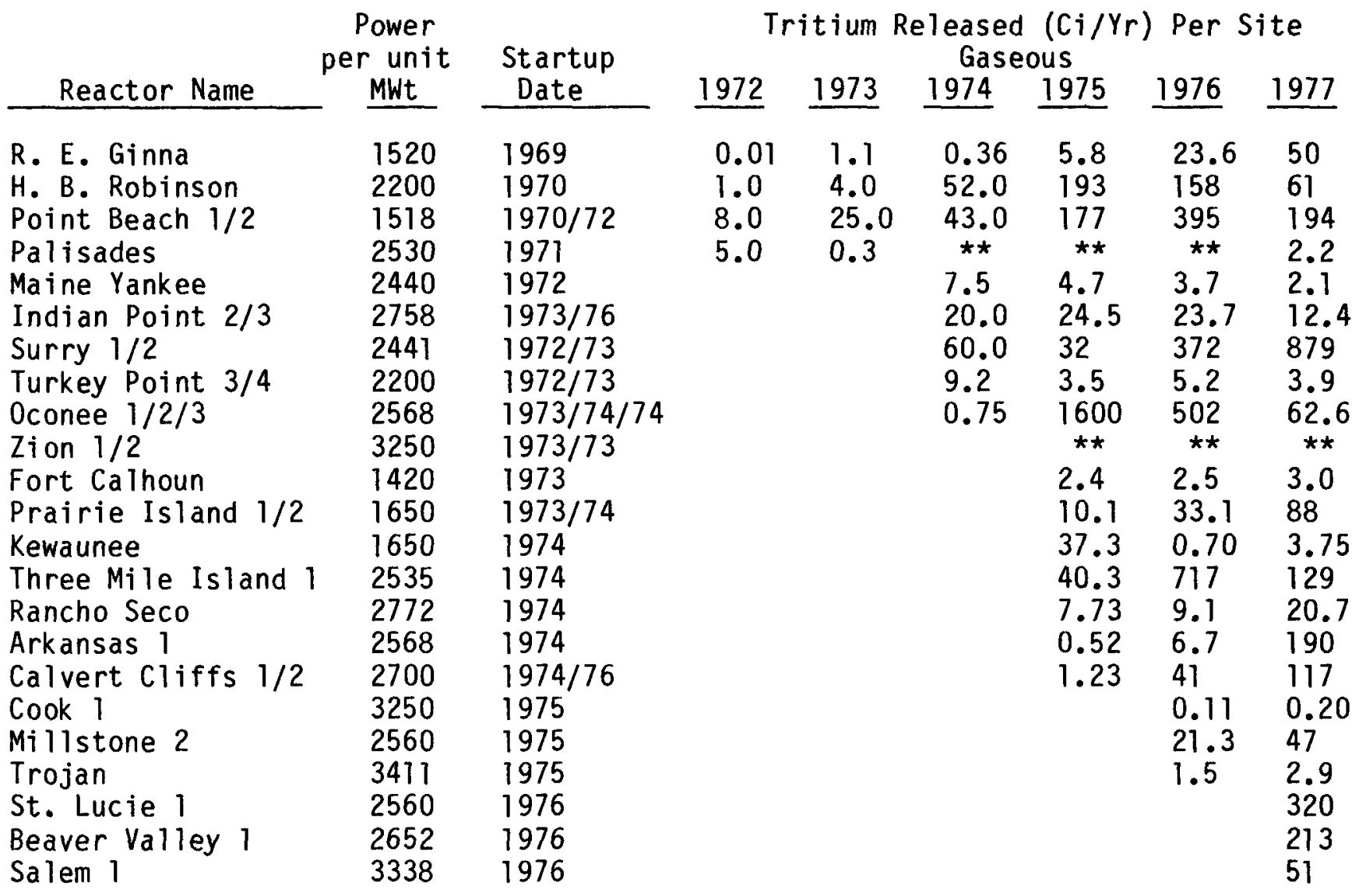

* Data from semiannual reports of reactors listed.

** No reported data. 
TABLE 2-29 (continued)

TRITIUM RELEASE DATA FROM OPERATING PWR'S WITH ZIRCALOY-CLAD FUELS*

\begin{tabular}{|c|c|c|c|c|c|c|c|c|}
\hline \multirow[b]{2}{*}{ Reactor Name } & \multirow{2}{*}{$\begin{array}{c}\text { Power } \\
\text { per unit } \\
\text { MWt }\end{array}$} & \multirow{2}{*}{$\begin{array}{c}\text { Startup } \\
\text { Date }\end{array}$} & \multicolumn{4}{|c|}{ Tritium Released $\left(\mathrm{C} i / \mathrm{Yr}_{r}\right)$} & \multicolumn{2}{|c|}{ Per Site } \\
\hline & & & 1972 & 1973 & 1974 & 1975 & 1976 & 1977 \\
\hline R. E. Ginna & 1520 & 1969 & 120 & 286 & 195 & 261 & 242 & 119 \\
\hline H. B. Robinson & 2200 & 1970 & 410 & 431 & 475 & 624 & 980 & 685 \\
\hline Point Beach $1 / 2$ & 1518 & $1970 / 72$ & 560 & 556 & 832 & 886 & 694 & 1000 \\
\hline Palisades & 2530 & 1971 & 210 & 185 & 8.3 & 41.3 & 9.6 & \\
\hline Maine Yankee & 2440 & 1972 & & & 219 & & & 153 \\
\hline Indian Point $2 / 3$ & 2758 & $1973 / 76$ & & & 48 & 366 & 332 & 371 \\
\hline Surry $1 / 2$ & 2441 & $1972 / 73$ & & & 246 & 442 & 782 & 408 \\
\hline Turkey Point $3 / 4$ & 2200 & $1972 / 73$ & & & 580 & 793 & 771 & 924 \\
\hline $\begin{array}{l}\text { Oconee } 1 / 2 / 3 \\
\text { Zion } 1 / 2\end{array}$ & 2568 & $1973 / 74 / 74$ & & & 124 & $3550+$ & $2192+$ & $1918 t$ \\
\hline & 3250 & $1973 / 73$ & & & & $39.4^{\top}$ & $1.1 \mathrm{~T}$ & 727 \\
\hline $\begin{array}{l}\text { Fort Calhoun } \\
\text { Prairie Island } 1 / 2\end{array}$ & $\begin{array}{l}1420 \\
1650\end{array}$ & $\begin{array}{l}1973 \\
1973 / 74\end{array}$ & & & & 763 & $\begin{array}{l}122 \\
1925\end{array}$ & 1349 \\
\hline Kewaunee & 1650 & 1974 & & & & 277 & 213 & 295 \\
\hline Three Mile Island 1 & 2535 & 1974 & & & & 463 & $189+t$ & \\
\hline Rancho Seco & 2772 & 1974 & & & & 13 & $0.0^{t \dagger}$ & $0.09^{\dagger t}$ \\
\hline Arkansas 1 & 2568 & 1974 & & & & 46 & 212 & 245 \\
\hline Calvert Cliffs $1 / 2$ & 2700 & $1974 / 76$ & & & & 263 & 274 & \\
\hline Cook 1 & 3250 & 1975 & & & & & 192 & 285 \\
\hline Millstone 2 & 2560 & 1975 & & & & & 277 & 211 \\
\hline Trojan & 3411 & 1975 & & & & & 36 & 311 \\
\hline St. Lucie 1 & 2560 & 1976 & & & & & & \\
\hline Beaver Valley 1 & 2652 & 1976 & & & & & & 108 \\
\hline & & 1976 & & & & & & 296 \\
\hline
\end{tabular}

* Data from semiannual reports of reactors listed.

+ No radioactive liquid wastes were discharged from Unit 2 during the entire year. Note: For 1975, there were no radioactive liquid wastes discharged from Unit 1 during the last 6 months.

${ }^{+t}$ Rancho Seco is designed to be a zero or very low liquid release plant. 
TABLE 2-29 (continued)

TRITIUM RELEASE DATA FROM OPERATING PWR'S WITH ZIRCALOY-CLAD FUELS*

\begin{tabular}{|c|c|c|c|c|c|c|c|c|}
\hline Reactor Name & $\begin{array}{l}\text { Power } \\
\text { per unit } \\
\text { MWt }\end{array}$ & $\begin{array}{l}\text { Startup } \\
\text { Date }\end{array}$ & $\begin{array}{c}\text { Total } \\
(\mathrm{Ci} \\
1972\end{array}$ & $\begin{array}{l}\text { Tritium } \\
\text { yr.-Mwt } \\
1973\end{array}$ & $\begin{array}{l}\text { Releas } \\
\text { at } 80 \% \\
1974\end{array}$ & $\begin{array}{l}\text { ed } \mathrm{Per} \\
\text { capac } \\
1975\end{array}$ & $\begin{array}{l}\text { Unit } \\
\text { iy) } \\
1976\end{array}$ & 1977 \\
\hline R. E. Ginna & 1520 & 1969 & 0.11 & 0.19 & 0.20 & 0.19 & 0.27 & 0.11 \\
\hline H. B. Robinson & 2200 & 1970 & 0.19 & 0.25 & 0.39 & 0.42 & 0.50 & 0.37 \\
\hline Point Beach $1 / 2$ & 1518 & $1970 / 72$ & 0.39 & 0.22 & 0.59 & 0.36 & 0.35 & 0.37 \\
\hline Palisades & 2530 & 1971 & 0.26 & 0.20 & - & - & - & 0.02 \\
\hline Maine Yankee & 2440 & 1972 & & & 0.14 & 0.09 & 0.13 & 0.07 \\
\hline Indian Point $2 / 3$ & 2758 & $1973 / 76$ & & & 0.04 & 0.17 & 0.19 & 0.08 \\
\hline Surry $1 / 2$ & 2441 & $1972 / 73$ & & & 0.11 & 0.11 & 0.32 & 0.30 \\
\hline Turkey Point $3 / 4$ & 2200 & $1972 / 73$ & & & 0.16 & 0.20 & 0.20 & 0.24 \\
\hline 0 conee $1 / 2 / 3$ & 2568 & $1973 / 74 / 74$ & & & 0.07 & 0.79 & 0.48 & 0.35 \\
\hline Zion $1 / 2$ & 3250 & $1973 / 73$ & & & & - & - & - \\
\hline Fort Ca Thoun & 1420 & 1973 & & & & 0.12 & 0.12 & 0.12 \\
\hline Prairie Island $1 / 2$ & 1650 & $1973 / 74$ & & & & 0.24 & 0.66 & 0.41 \\
\hline Kewaunee & 1650 & 1974 & & & & 0.20 & 0.14 & 0.19 \\
\hline Three Mile Island 1 & 2535 & 1974 & & & & 0.20 & 0.46 & 0.13 \\
\hline Rancho Seco & 2772 & 1974 & & & & 0.24 & 0.01 & 0.01 \\
\hline Arkansas 1 & 2568 & 1974 & & & & 0.21 & 0.13 & 0.19 \\
\hline Calvert cliffs $1 / 2$ & 2700 & $1974 / 76$ & & & & 0.13 & 0.11 & 0.16 \\
\hline Cook 1 & 3250 & 1975 & & & & & 0.06 & 0.13 \\
\hline Millstone 2 & 2560 & 1975 & & & & & 0.14 & 0.13 \\
\hline Trojan & 3411 & 1975 & & & & & 0.04 & 0.10 \\
\hline St. Lucie 1 & 2560 & 1976 & & & & & & 0.22 \\
\hline Beaver Valley 1 & 2652 & 1976 & & & & & & 0.22 \\
\hline Salem 1 & 3338 & 1976 & & & & & & 0.36 \\
\hline
\end{tabular}

* Data from semiannual reports of reactors 1 isted. 
TABLE 2-30

TRITIUM RELEASE RATE FROM OPERATING PWR'S

AS A FUNCTION OF NUMBER OF YEARS OF OPERATION

(Ci/yr.-MWt per unit at $80 \%$ capacity)

\begin{tabular}{|c|c|c|c|c|c|c|c|}
\hline Ginna & 0.11 & 0.19 & 0.20 & 0.19 & 0.27 & 0.11 & 0.17 \\
\hline Robinson & 0.19 & 0.25 & 0.39 & 0.42 & 0.50 & 0.37 & - \\
\hline Pt. Beach $1 / 2$ & 0.39 & 0.22 & 0.59 & 0.36 & 0.35 & 0.37 & 0.51 \\
\hline Maine Yankee & 0.14 & 0.09 & 0.13 & 0.07 & 0.18 & - & - \\
\hline Indian Pt. $2 / 3$ & 0.04 & 0.17 & 0.19 & 0.08 & - & & \\
\hline Surry $1 / 2$ & 0.11 & 0.11 & 0.32 & 0.30 & - & & \\
\hline Turkey Pt. $3 / 4$ & 0.16 & 0.20 & 0.20 & 0.24 & 0.20 & & \\
\hline Oconee $1 / 2 / 3$ & 0.07 & 0.77 & 0.48 & 0.35 & 0.19 & & \\
\hline Ft. Calhoun & 0.12 & 0.12 & 0.12 & 0.13 & - & & \\
\hline Prairie Is. $1 / 2$ & 0.24 & 0.66 & 0.41 & 0.25 & & & \\
\hline Kewaunee & 0.20 & 0.14 & 0.19 & 0.20 & - & & \\
\hline TMI 1 & 0.20 & 0.46 & 0.13 & 0.17 & - & & \\
\hline Arkansas 1 & 0.21 & 0.13 & 0.19 & - & - & & \\
\hline Calvert Cliffs $1 / 2$ & 0.13 & 0.11 & 0.16 & - & - & & \\
\hline Cook & 0.06 & 0.13 & 0.31 & - & - & & \\
\hline Millstone & 0.14 & 0.13 & - & - & - & & \\
\hline Trojan & 0.04 & 0.10 & - & - & - & & \\
\hline St. Lucie & 0.22 & - & - & - & - & & \\
\hline Beaver Valley & 0.22 & 0.51 & - & - & - & & \\
\hline Salem & 0.36 & 0.41 & - & - & - & & \\
\hline Average & 0.16 & 0.29 & 0.30 & 0.25 & 0.26 & 0.31 & 0.40 \\
\hline
\end{tabular}


TABLE 2-31

TRITIUM RELEASE DATA FROM OPERATING PWR'S PERCENT OF TOTAL TRITIUM RELEASED IN LIQUID EFFLUENTS

\begin{tabular}{|c|c|c|c|c|c|c|}
\hline Reactor & 1972 & 1973 & 1974 & 1975 & 1976 & 1977 \\
\hline R. E. Ginna & 100.0 & 99.6 & 99.8 & 97.8 & 91.1 & 70.4 \\
\hline H. B. Robinson & 99.8 & 99.1 & 90.1 & 76.4 & 86.1 & 91.8 \\
\hline Point Beach $1 / 2$ & 98.6 & 95.7 & 95.1 & 83.3 & 63.7 & 83.8 \\
\hline Palisades & 97.7 & 99.8 & $\star \star$ & $\star \star$ & $\star \star$ & 96.2 \\
\hline Maine Yankee & & & 96.7 & 97.4 & 99.0 & 98.6 \\
\hline Indian Point $2 / 3$ & & & 70.6 & 93.7 & 93.3 & 96.8 \\
\hline Surry $1 / 2$ & & & 80.4 & 93.2 & 67.8 & 31.7 \\
\hline Turkey Point $3 / 4$ & & & 98.4 & 99.6 & 99.3 & 99.6 \\
\hline Oconee $1 / 3$ & & & 99.4 & 68.9 & 81.4 & 96.8 \\
\hline Zion $1 / 2$ & & & & $\star \star$ & $\star \star$ & $\star \star$ \\
\hline Fort Calhoun & & & & 97.9 & 98.0 & 98.1 \\
\hline Prairie Island $1 / 2$ & & & & 98.7 & 98.3 & 93.9 \\
\hline Kewaunee & & & & 88.1 & 99.7 & 98.7 \\
\hline Three Mile Island 1 & & & & 92.0 & 20.9 & 59.8 \\
\hline Rancho Seco & & & & 94.5 & $0.0^{t \dagger}$ & $0.43^{\dagger}$ \\
\hline Arkansas 1 & & & & 99.9 & 96.9 & 56.3 \\
\hline Calvert Cliffs $1 / 2$ & & & & 99.5 & 87.0 & 83.1 \\
\hline Cook 1 & & & & & 100.0 & 100.0 \\
\hline Millstone 2 & & & & & 92.9 & 81.8 \\
\hline Trojan & & & & & 96.0 & 99.1 \\
\hline St. Lucie 1 & & & & & & 43.1 \\
\hline Beaver Valley 1 & & & & & & 33.6 \\
\hline Salem 1 & & & & & & 85.3 \\
\hline Weighted Average* & 99.2 & 98.0 & 91.1 & 89.5 & 83.5 & 78.5 \\
\hline
\end{tabular}

* Average weighted by nuclear thermal output per unit. ** No reported data.

t† Rancho Seco is designed to be a zero or very low liquid release plant. 
The difference between the tritium calculated to be available for release from the primary coolant and the tritium calculated to be released in liquid effluents is considered to be released as a vapor through building ventilation exhaust systems. Based on measurements taken in 1975 through 1977 at Ginna, Calvert Cliffs and Three Mile Island (Ref. 7) and in 1976 and 1977 at Zion 1/2 (Ref. 5), and in 1977 at Turkey Point (Ref. 6), in 1978-79 at Rancho Seco (Ref .43), and in 1980-1981 at Prairie Island 1/2 (Ref. 42), Table 2-32 provides the distribution of tritium released from various sources within the plant. Based on data in Table 2-32, approximately $32 \%$ of tritium in gaseous effluents is released from the auxiliary building, 50\% from the refueling area, and $18 \%$ from the containment. Since the refueling area in a PWR generally vents to the same release point as the auxiliary building, we have included these two releases together in our parameter.

\subsubsection{DECONTAMINATION FACTORS FOR DEMINERALIZERS}

\subsubsection{Parameter}

\begin{tabular}{|c|c|c|c|}
\hline & Anion & $\underline{C s, R b}$ & $\begin{array}{l}\text { Other } \\
\text { Nuclides }\end{array}$ \\
\hline $\begin{array}{l}\text { Mixed bed purification } \\
\text { system }\left(\mathrm{LiBO}_{3}\right)\end{array}$ & 100 & 2 & 50 \\
\hline Boron recycle system & 10 & 2 & 10 \\
\hline Evaporator condensate $\left(\mathrm{H}^{+} \mathrm{OH}^{-}\right)$ & 5 & 1 & 10 \\
\hline Radwaste $\left(\mathrm{H}^{+} \mathrm{OH}^{-}\right)$ & $10^{2}(10)$ & $2(10)$ & $10^{2}(10)$ \\
\hline Steam Generator Blowdown & $10^{2}(10)$ & $10(10)$ & $10^{2}(10)$ \\
\hline Cation bed $\left(\mathrm{H}^{+}\right)$(any system) & $1(1)$ & $10(10)$ & $10(10)$ \\
\hline Anion bed $\left(\mathrm{OH}^{-}\right)$(any system) & $10^{2}(10)$ & $1(1)$ & $1(1)$ \\
\hline Powdex (any system) & $10(10)$ & $2(10)$ & $10(10)$ \\
\hline
\end{tabular}

Note: For two demineralizers in series, the DF for the second demineralizer is given in parentheses.

The following operating conditions were considered for the evaluation of demineralizer performance:

1. The DF is dependent upon the inlet radioactivity and ion concentrations and bed volume ion exchange capacity. For demineralizer performance within the same range of controlled operating conditions, the DF increases with inlet radioactivity concentration and decreases with bed volume throughout. 
TABLE 2-32*

\section{DISTRIBUTION OF TRITIUM RELEASE IN GASEOUS EFFLUENTS}

Source of Gaseous Tritium Release (\% of Total)

\section{Plant}

Ginna (Ref. 7)

Calvert Cliffs 1 (Ref. 7)

Three Mile Is. 1 (Ref. 7)

Zion $1 / 2$ (Ref. 5)

Turkey Point $3 / 4$ (Ref. 6)

Rancho Seco (Ref. 43)

Prairie Island $1 / 2$ (Ref. 43)

Average

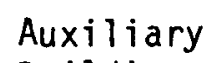

Building

31

38

5

79

75

92

7.2

32

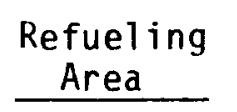

69

46

43

WA

17

WA

91.8

50
Containment Building

NM

16

52

21

8

8

1.0

18

NM - Not measured.

WA - Release from refueling area combined with auxiliary building release.

* The following method is used to determine the ${ }^{3} H$ release in this table. Containment Building operation average $\%$ of total release

$$
(16+52+21+8+8+1) \% \div(6)=17.7 \%=18 \%
$$

Then the Refueling Area for Ginna is reduced by

$18 \%$, i.e., $(69-18) \%=57 \%$

Now the operation average $\%$ of the total release for the Refueling Area is

$(51+46+43+17+91.8) \% \div(5)=50 \%$

Then use $(79-50) \%=29 \%$ and $(92-50) \%=42 \%$ into Zion and Rancho Seco auxiliary building's data, respectively, to calculate the operational average of Auxiliary Building release which is equal to

$(31+38+5+29+75+42+7.2) \% \div(7)=32 \%$ 
2. When two demineralizers are used in series, the first demineralizer will have a higher DF than the second. However, the data in Reference 32 indicate that $C_{s}$ and $\mathrm{Rb}$ will be more strongly exchanged in the second demineralizer in series than the first as the concentration of preferentially exchanged competing nuclides is reduced.

3. As indicated in Reference 32, compounds of $Y$, Mo, and Tc form colloidal particles that tend to plate out on solid surfaces. Mechanisms such as plateout on the relatively large surface areas provided by demineralizer resin beds result in removal of these nuclides to the degree stated above. An analysis of effluent release data indicates that these nuclides, although present in the primary coolant, are not found in the effluent streams.

\subsubsection{Bases}

The decontamination factors (DF's) for purification, radwaste, and evaporator condensate demineralizers are based on (1) source term measurements made at Fort Calhoun, Zion, Turkey Point, Prairie Island, and Rancho Seco stations by In-Plant Source Term Measurement Program (Refs. 4, 5, 6, 42, and 43); (2) the findings of a generic review in the nuclear industry by the Oak Ridge National Laboratory (ORNL) (Ref. 32); and (3) measurements taken at Three Mile Island 1 (Ref. 40). The DF's for the remaining demineralizers are based on ORNL findings.

The ORNL generic review contains operating and theoretical data which provides a basis for the numerical values assigned. The ORNL data were projected to obtain a performance value expected over an extended period of operation. It is considered that attempts to extend the service life of the resin will reduce the DF's below those expected under controlled operating conditions.

Average DF's for Ft. Calhoun, Zion, Turkey Point, Rancho Seco, and Prairie Island stations were obtained by dividing the average inlet radionuclide concentration of samples by that of the average outlet concentrating for each nuclide.

Based on the data in References $4,5,6,32,42$, and 43 , the DF used for the parameter was that considered to be representative of the data.

\subsubsection{DECONTAMINATION FACTORS FOR EVAPORATORS}

\subsubsection{Parameter}

Decontamination Factors

Al1 Nuclides

Except Iodine Iodine

Miscellaneous radwaste evaporators

$10^{3}$

$10^{2}$

Boric acid evaporators

$10^{3}$

$10^{2}$

Separate evaporator for detergent wastes

$10^{2}$

$10^{2}$ 


\subsubsection{Bases}

The decontamination factors for evaporators are based on: (1) source term measurements made at Fort Calhoun, Zion, Turkey Point, Prairie Island, and Rancho Seco stations by In-Plant Source Term Measurement Program (Ref. 4, 5, 6, 42, and 43) and (2) the findings of a generic review in the nuclear industry by the Oak Ridge National Laboratory (Ref. 33).

Average DF's for Zion, Ft. Calhoun, Turkey Point, Rancho Seco, and Prairie Island, were obtained by dividing the average inlet radioactivity of samples by the average outlet radioactivity of samples for each radionuclide.

Based on the data given in References $4,5,6,33,42$, and 43 , the DF used for the parameter was that considered to be the most representative of the data.

\subsubsection{DECONTAMINATION FACTORS FOR LIQUID RADWASTE FILTERS}

\subsubsection{Parameter}

A DF of 1 for liquid radwaste filters is assigned for all radionuclides.

\section{2 .20 .2 Bases}

Reference 34 contains findings of a generic review by ORNL of 1 iquid radwaste filters used in the nuclear industry. Due to various filter types and filter media employed, reported values of decontamination factors vary widely, with no discernible trend. The principal conclusion reached in the ORNL report is that no credit should be assigned to liquid radwaste filters (DF of 1) until a larger data base is obtained.

Additional data from Ft. Calhoun (Ref. 4), Zion 1/2 (Ref. 5) and Turkey Point 3/4 (Ref. 6), Rancho Seco (Ref. 43), and Prairie Is land $1 / 2$ (Ref. 42) indicate that decontamination factors in liquid radwaste filters vary widely from less than 1 to greater than 50 (with a mean value of 1.3). Therefore a DF of 1 for liquid radwaste filters is used.

\subsubsection{DECONTAMINATION FACTORS FOR REVERSE OSMOSIS}

\subsubsection{Parameter} radwastes.

Overall DF of 30 for laundry wastes and DF of 10 for other liquid

\section{2 .21 .2 Bases}

Reverse osmosis processes are generally run as semibatch processes. The concentrated stream rejected by the membrane is recycled until a desired fraction of the batch is processed through the membrane. The ratio of the volume processed through the membrane to the inlet batch volume is the percent recovery. The DF normally specified for the 
process is the ratio of nuclide concentrations in the concentrated liquor stream to the concentrations in the effluent stream. This ratio is termed as the membrane DF (DF $)$. For source term calculations, the system DF (DF $)$ should be used. The system DF is the ratio of the nuclide concentrations in the feed stream to those in the effluent stream. The relationship between the system DF and the membrane DF is nonlinear and is a function of the percent recovery. This relationship can be expressed as follows:

$$
D F_{S}=\frac{F}{1-(1-F)^{1 / D F_{m}}}
$$

where

$$
\begin{aligned}
& D F_{m} \text { is the membrane } D F ; \\
& D F \text { is the system } D F \text {; and } \\
& F \quad \text { is the ratio of effluent volume to inlet volume (fractional } \\
& \text { recovery). }
\end{aligned}
$$

Tables 2-33 through 2-36 give membrane DF's derived from operating data at Point Beach, Ginna and Robinson (Ref. 35) and laboratory data on simulated radwaste liquids (Ref. 36). These data indicate that the overall membrane DF is approximately 100 . The percent recovery for 1 iquid radwaste processes using reverse osmosis is expected to be approximately $95 \%$, i.e., $5 \%$ concentrated liquor. Using these values in the above equation, the system DF is approximately 30.

$$
D F_{s}=\frac{0.95}{1-(1-0.95)^{1 / 100}}=30
$$

The data used were derived mainly from tests on laundry wastes. The DF for other plant wastes, e.g., floor drain wastes, is expected to be lower because of the higher concentrations of iodine and cesium isotopes. As indicated by the data in Tables 2-33, 2-35 and 2-36, the membrane DF for these isotopes is lower than the average membrane DF used in the evaluation for laundry waste.

\subsubsection{GUIDELINES FOR CALCULATING LIQUID WASTE HOLDUP TIMES}

The holdup times to permit radioactive decay applied to the input waste streams are calculated using the following parameters:

1. The collection time should be calculated for an $80 \%$ volume change in the tank, based on the liquid waste flow rates from the inlet sources. 
TABLE 2-33

REVERSE OSMOSIS DECONTAMINATION FACTORS, GINNA STATION

\begin{tabular}{|c|c|c|c|}
\hline Nuclide & $\begin{array}{c}\text { Concentrate } \\
\text { Activity } \\
\left({ } \mathrm{Ci} / \mathrm{cm}^{3}\right) \\
\end{array}$ & $\begin{array}{l}\text { Product Activity } \\
\left(\mu \mathrm{Ci} / \mathrm{cm}^{3}\right) \\
\end{array}$ & Membrane DF \\
\hline $\mathrm{Ce}-144$ & $2.68(-4)$ & $<2.2(-7)$ & 1200 \\
\hline Co-58 & $8.55(-5)$ & $<3.4(-8)$ & 2500 \\
\hline Ru-103 & $5.83(-5)$ & $<5.5(-8)$ & 1100 \\
\hline Cs -137 & $4.09(-4)$ & $6.6(-6)$ & 60 \\
\hline$C s-134$ & $2.02(-4)$ & $3.2(-6)$ & 60 \\
\hline $\mathrm{Nb}-95$ & $5.35(-5)$ & $<5.3(-8)$ & 1000 \\
\hline$Z r-95$ & $2.36(-5)$ & $\langle 3.7(-8)$ & 640 \\
\hline$M n-54$ & $8.82(-5)$ & $<3.4(-8)$ & 2600 \\
\hline Co-60 & $9.62(-4)$ & $<8.1(-8)$ & 12,000 \\
\hline Total isotopic & $2.15(-3)$ & $9.8(-6)$ & 219 \\
\hline Gross beta & $1.63(-3)$ & $1.86(-5)$ & 88 \\
\hline \multirow[t]{2}{*}{ TOTAL } & $3.78(-3)$ & $2.84(-5)$ & \\
\hline & & & 133 \\
\hline
\end{tabular}


TABLE 2-34

REVERSE OSMOSIS DECONTAMINATION FACTORS, POINT BEACH

\begin{tabular}{|c|c|c|c|c|}
\hline Date & Time & $\begin{array}{c}\text { Concentrate } \\
\text { Activity } \\
(\mu \mathrm{Ci} / \mathrm{ml}) \\
\end{array}$ & $\begin{array}{c}\text { Product Activity } \\
(\mu \mathrm{C} / \mathrm{ml})\end{array}$ & Membrane DF \\
\hline \multirow[t]{3}{*}{$6 / 14 / 71$} & 0840 & $1.1(-5)$ & $6.8(-7)$ & 16 \\
\hline & 1225 & $6.3(-5)$ & $4.2(-7)$ & 150 \\
\hline & 1350 & $6.8(-5)$ & $3.2(-7)$ & 213 \\
\hline \multirow[t]{5}{*}{$6 / 15 / 71$} & 1030 & $2.7(-4)$ & $3.1(-6)$ & 87 \\
\hline & 1315 & $1.0(-4)$ & $1.7(-6)$ & 59 \\
\hline & 1440 & $1.3(-4)$ & $1.1(-7)$ & 1200 \\
\hline & 1510 & $1.6(-4)$ & $1.1(-7)$ & 1500 \\
\hline & 1530 & $1.8(-4)$ & $5.7(-7)$ & 316 \\
\hline \multirow[t]{2}{*}{ TOTAL } & & $9.8(-4)$ & $7.0(-6)$ & \\
\hline & \multicolumn{2}{|c|}{ Average } & & 140 \\
\hline
\end{tabular}


TABLE $2-35$

REVERSE OSMOSIS DECONTAMINATION FACTORS,

H. B. ROBINSON NO. 2 STATION

$\begin{array}{cccc} & \text { Co-60 } & \underline{\text { Co-58 }} & \frac{I-131}{29} \\ 264 & --- & 14 \\ 382 & -- & 20 \\ 436 & 229 & 39 \\ 107 & 490 & 26 \\ 76 & 131 & 11 \\ \text { Average } & 94 & 220 & 34\end{array}$


TABLE 2-36

EXPECTED REVERSE OSMOSIS DECONTAMINATION FACTORS

FOR SPECIFIC NUCLIDES

\begin{tabular}{|c|c|c|c|}
\hline Nuclide & $\begin{array}{c}\text { Concentrate } \\
\text { Activity } \\
(\mu \mathrm{Ci} / \mathrm{ml}) \\
\end{array}$ & $\begin{array}{c}\text { Product Activity } \\
(\mu \mathrm{Ci} / \mathrm{ml}) \\
\end{array}$ & Membrane DF \\
\hline Co- 60 & $2.5(-4)$ & $5(-7)$ & 500 \\
\hline Mo-99 & $3.8(-2)$ & $1(-3)$ & 40 \\
\hline $\begin{array}{l}I-131,132, \\
133,134,135\end{array}$ & $1.2(-1)$ & $4(-3)$ & 30 \\
\hline Cs-134, 137 & $4.3(-2)$ & $2(-4)$ & 200 \\
\hline TOTAL & $2(-1)$ & $5(-3)$ & \\
\hline AVERAGE & & & 40 \\
\hline
\end{tabular}


2. The process time is the total time liquid remains in the system for processing, based on the flow rate through the limiting process step.

3. The discharge time is one-half the time required to empty the final liquid waste sample (test) tank to the environment. This value is based on the maximum rate of the discharge pumps and the nominal tank volume.

The calculated values in 1. and the total of 2. and 3. are used as inputs to the computer PWR-GALE Code.

\subsubsection{ADJUSTMENT TO LIQUID RADWASTE SOURCE TERMS FOR ANTICIPATED OPERATIONAL OCCURRENCES}

\subsubsection{Parameter}

1. Increase the calculated source term by $0.16 \mathrm{Ci} / \mathrm{yr}$ per reactor using the same isotopic distribution as for the calculated source term to account for anticipated operational occurrences such as operator errors that result in unplanned releases.

2. Assume evaporators to be unavailable for two consecutive days per week for maintenance. If a 2-day hold-up capacity exists in the system (including surge tanks) or an alternative evaporator is available, no adjustment is needed. If less than a 2-day capacity is available, assume the waste excess is handled as follows:

a. High-purity or low-purity waste - Processed through an alternative system (if available) using a discharge fraction consistent with the lower purity system.

b. Chemical Waste - Discharged to the environment to the extent holdup capacity or an alternative evaporator is available.

3. The following methods should be used for calculating holdup times and effective system DF:

a. Holdup Capacity - If two or more holdup tanks are available, assume one tank is full ( $80 \%$ capacity) with the remaining tanks empty at the start of the two-day outage. If there is only one holdup tank, assume that it is $40 \%$ full at the start of the two-day outage with a usable capacity of $80 \%$.

b. Effective System DF - Should the reserve storage capacity be inadequate for waste holdup over a two-day evaporator outage, and should an alternate evaporator be unavailable to process the wastes from the out-of-service evaporator, the subsystem DF should be adjusted to show the effect of the evaporator outage. 
For example, a DF of $10^{5 t}$ was calculated for a radwaste demineralizer and radwaste evaporator in series. If an adjustment were required for the evaporator being out-of-service two days/week, with only one day holdup tank capacity, then the effective system DF can be calculated as follows:

1. For 6 days $(7-2+1)$ out of 7 the system DF would be $10^{5}$.

2. For the remaining one day, the system DF would be $10^{2}$ (only the demineralizer DF is considered). The effective DF is:

$$
D F=\left[\left(\frac{6}{7}\right)\left(10^{-5}\right)+\left(\frac{1}{7}\right)\left(10^{-2}\right)\right]^{-1}=7.0 \times 10^{2}
$$

\subsubsection{Bases}

Reactor operating data over an 8 year period, January 1970 through December 1977, representing 154 reactor years of operation, were evaluated to determine the frequency and extent of unplanned liquid releases. During the period evaluated, 62 unplanned liquid releases occurred; 23 due to operator errors, 26 due to component failures, 5 due to inadequate procedures or failure to follow procedures, and the remaining 8 due to miscellaneous causes such as design errors. Table 2-37 summarizes the findings of this evaluation. Based on the data provided in Table 2-37 it is estimated that $0.16 \mathrm{Ci} /$ reactor year will be discharged in unplanned releases in liquid effluents.

The availability of evaporators in waste treatment systems is expected to be in the range of 60 to $80 \%$. Unavailability is attributed to scaling, fouling of surfaces, instrumentation failures, corrosion, and occasional upsets resulting in high carryovers requiring system cleaning. A value of two consecutive days unavailability per week was chosen as being representative of operating experience. For systems having sufficient tank capacity to collect and hold wastes during the assumed 2-day/week outage, no adjustments are required for the source term. If less capacity is available, the difference between the waste expected during two days of normal operation and the available holdup capacity is assumed to follow an alternative route for processing. Since processing through an alternative route implies mixing of wastes having different purities and different dispositions after treatment, it is assumed that the fraction of waste discharged following processing will be that normally assumed for the less pure of the two waste streams combined.

Since chemical and regenerant wastes are not amenable to processes other than evaporation, it is assumed that unless an alternative evaporation route is available, chemical and regenerant wastes in excess of the storage capacity are discharged without treatment.

$+10^{3}$ (Evap.) $\times 10^{2}$ (demin) $=10^{5}$ is obtained using DF's from Section 2.2.19.1. 
TABLE $2-37$

FREQUENCY AND EXTENT OF UNPLANNED LIQUID RADWASTE

RELEASES FROM OPERATING PLANTS*

Unplanned Liquid Releases

Total number (unplanned releases) 62

$\begin{array}{ll}\text { Fraction due to personnel error } & 0.37\end{array}$

Fraction due to component failure $\quad 0.42$

Fraction due to inadequate procedures or failure 0.08 to follow procedures

$\begin{array}{ll}\text { Fraction due to other causes } & 0.13\end{array}$

Approximate activity (Ci) 24.

$\begin{array}{ll}\text { Fraction of cumulative occurrence per reactor } & 0.16\end{array}$ year ( $\mathrm{plants}$ reporting releases $<5$ gals of liquid waste/reactor year)

Fraction of cumulative occurrences per reactor $\quad 0.28$ year (plants reporting activity released $>0.01 \mathrm{Ci} /$ reactor year)

$\begin{array}{ll}\text { Activity per release ( } \mathrm{C} i / \text { release) } & 0.39\end{array}$

$\begin{array}{ll}\text { Activity released per reactor year (Ci/reactor year) } & 0.16\end{array}$

Volume of release per reactor year (gal/reactor year) 633.

* Values in this table are based on reported values in 1970-1977 Licensee Event Reports representing 154 reactor years of operation. 


\subsubsection{ATMOSPHERIC STEAM DUMP}

\subsubsection{Parameter}

Noble gases and radioiodines released to the atmosphere from the steam dumps because of turbine trips and low-power physics tests will have a negligible effect on the calculated gaseous source term.

\subsubsection{Bases}

In the evaluation, consideration has been given to the quantity of noble gases and radioiodine released to the atmosphere from steam dumps because of low-power physics testing and turbine trips from full power. The evaluation indicates that the iodine-131 and noble gas releases will be less than $1 \%$ of the turbine building gaseous source term.

The evaluation of releases following a turbine trip from full power is based on the following parameters:

1. An average of two turbine trips annually;

2. $40 \%$ turbine bypass capacity to the main condenser;

3. Two-second rod insertion time required to scram the reactor following a turbine trip; and

4. Twelve-second cycle time to recirculate one primary coolant volume through the reactor and steam generator.

The above parameters are based on a 3400-MWt RESAR-3 reactor. Using these parameters, it is postulated that steam will continue to be produced at a full-power rate during the time the control rods are inserted and during the time required to recirculate one primary coolant volume. After this time, the turbine bypass will be adequate to handle steam generated from decay heat. The quantity of steam released

$$
\begin{aligned}
& =\left(1.5 \times 10^{7} \mathrm{lb} / \mathrm{hr}\right)(60 \%)(14 \mathrm{sec})(2 \mathrm{trips} / \text { year })(454 \mathrm{~g} / 1 \mathrm{~b})\left(\frac{\mathrm{hr}}{3600 \mathrm{sec}}\right) \\
& =3 \times 10^{7} \mathrm{~g} \text {-steam/yr }
\end{aligned}
$$

The iodine-131 concentration in the main steam for a $U$-tube steam generator is approximately $1.8 \times 10^{-8} \mu \mathrm{Ci} / \mathrm{g}$-steam from Table 2-2.

Based on the steam release calculated above, the associated iodine131 release is approximately $6.0 \times 10^{-7} \mathrm{Ci} / \mathrm{yr}$.

$$
\begin{aligned}
I-131 / y r & =\left(3.2 \times 10^{7} \frac{\text { g-steam }}{y r}\right)\left(1.8 \times 10^{-8} \mu C i / g \text {-steam }\right)\left(10^{-6} \frac{\mathrm{Cj}}{\mu \mathrm{j} j}\right) \\
& =5.8 \times 10^{-7} \mathrm{Ci} / \mathrm{yr}
\end{aligned}
$$


Releases due to low-power physics testing are calculated based on one 10-hour release of steam each year following a refueling. For a RESAR-3 reactor, low-power physics testing is conducted at $5 \%$ power. The conditions given above for power level and steady-state main steam iodine-131 activity are used. In addition, it is assumed that the reactor will be shut down for 30 days for refueling prior to low-power physics testing. The iodine-131 releases are calculated to be approximately $4.6 \times 10^{-6} \mathrm{Ci} / \mathrm{yr}$ using the following equation:

$$
\begin{aligned}
& I-131 / y r=\left(1.5 \times 10^{7} \mathrm{Ib} / \mathrm{hr} \text { steam }\right)(0.05)(454 \mathrm{~g} / 1 \mathrm{~b})(10 \mathrm{hr} / \mathrm{yr}) \\
& \left(1.8 \times 10^{-8} \mu \mathrm{Ci} / \mathrm{g} \text {-steam }\right) \exp \left[\frac{-(0.693)(30 \text { days })}{(8.05 \text { days })}\right] 10^{-6} \mathrm{Ci} / \mu \mathrm{Ci} \\
& I-131 / \mathrm{yr}=4.6 \times 10^{-6} \mathrm{Ci} / \mathrm{yr}
\end{aligned}
$$

\subsubsection{CARBON-14 RELEASES}

\subsubsection{Parameter}

The annual quantity of carbon-14 released from a pressurized water reactor is $7.3 \mathrm{Ci} / \mathrm{yr}$. It is assumed that most of the carbon-14 will form volatile compounds that will be released from the waste gas processing system and from the containment and auxiliary building atmospheres to the environment.

\section{2 .25 .2 Bases}

The annual release of $7.5 \mathrm{Ci}$ of carbon-14 is based on measurements at ten operating PWR's presented in Table 2-38. Kunz et al. (Ref. 37)

found that the carbon-14 reacts to form volatile compounds (principally $\mathrm{CH}_{4}$, $\mathrm{C}_{2} \mathrm{H}_{6}$, and $\mathrm{CO}_{2}$ ) that are collected in the waste gas processing system through degassing of the primary coolant and released to the environment via the plant vent. Data from Refs. 4, 5, 6, 42, and 43 also indicate carbon-14 is released from the containment and auxiliary building vent as a result of leakage of primary coolant into the containment and auxiliary building atmospheres.

As shown in Table 2-39, an average of measurements, made at Turkey Point 3 and 4, Zion 1 and 2, Fort Calhoun, Prairie Island 1 and 2, and Rancho Seco indicates that the release of carbon-14 breaks down to $22.6 \%$ from the containment building, $61.0 \%$ from the auxiliary building vents and $16.4 \%$ from the waste gas processing system. Therefore on this basis, it is assumed that $1.6 \mathrm{Ci} / \mathrm{yr}$ of carbon-14 is released from the containment building, $4.5 \mathrm{Ci} / \mathrm{yr}$ of carbon-14 is released from the auxiliary building vents and $1.2 \mathrm{Ci} / \mathrm{yr}$ of carbon-14 is released from the waste gas processing system. 


\begin{tabular}{|c|c|c|c|c|}
\hline Plant* & $\underline{1975}$ & 1977 & 1978 & $\begin{array}{c}\text { Annual Average } \\
\mathrm{Ci} / \mathrm{yr} \text {-unit }\end{array}$ \\
\hline Conn. Yankee & 44 & 40 & 70 & 46 \\
\hline Yankee Rowe & 1.6 & 0.13 & 0.33 & 0.58 \\
\hline \multicolumn{2}{|l|}{ Plant** } & \multicolumn{2}{|l|}{ Area } & $\begin{array}{c}\text { Annual Release } \\
\text { Ci/yr-unit } \\
\end{array}$ \\
\hline \multirow[t]{3}{*}{ Turkey Point $3 / 4$} & & $\begin{array}{l}\text { Aux. Bldg. } \\
\text { Containment }\end{array}$ & & $\begin{array}{l}2.4 \\
0.075\end{array}$ \\
\hline & & $\begin{array}{l}\text { WGPS }^{\dagger} \\
\text { Spent Fuel Area }\end{array}$ & & $\begin{array}{l}0.82 \\
0.38 \\
\end{array}$ \\
\hline & & Total & & 3.7 \\
\hline \multirow[t]{2}{*}{ Fort Calhoun } & & $\begin{array}{l}\text { Fuel Pool and Aux. Bldg } \\
\text { WGPS } \\
\text { Containment Bldg. }\end{array}$ & & $\begin{array}{l}0.30 \\
0.81 \\
0.78 \\
\end{array}$ \\
\hline & & Total & & 1.9 \\
\hline \multirow[t]{2}{*}{ Zion $1 / 2$} & & $\begin{array}{l}\text { Cont. Bldg. } \\
\text { Fuel Handling and Aux. } \\
\text { WGPS }\end{array}$ & Bldg. & $\begin{array}{l}1.8 \\
1.4 \\
0.062 \\
\end{array}$ \\
\hline & & Total & & 3.3 \\
\hline \multirow[t]{2}{*}{ Prairie Island $1 / 2$} & & $\begin{array}{l}\text { Cont. Building } \\
\text { Fuel Handling and Aux. } \\
\text { WGPS }\end{array}$ & Bldg. & $\begin{array}{l}0.016 \\
3.3 \\
0.25 \\
\end{array}$ \\
\hline & & Total & & 3.6 \\
\hline \multirow{3}{*}{\multicolumn{2}{|c|}{ Rancho Seco }} & $\begin{array}{l}\text { Cont. Building } \\
\text { Fuel Handling and Aux. } \\
\text { WGPS }\end{array}$ & B $1 \mathrm{dg}$. & $\begin{array}{l}0.9 \\
1.85 \\
0.85 \\
\end{array}$ \\
\hline & & Total & & 3.6 \\
\hline & & Average & & 7.3 \\
\hline
\end{tabular}


TABLE 2-39

DISTRIBUTION OF CARBON-14 RELEASED IN GASEOUS EFFLUENTS

\begin{tabular}{|c|c|c|c|}
\hline Plant & $\begin{array}{l}\text { Plant Areas: } \\
\text { Containment }\end{array}$ & $\begin{array}{l}\text { Aux. Bldg, and } \\
\text { Fuel Handling } \\
\end{array}$ & WGPS \\
\hline Turkey Point $3 / 4$ & $2 \%$ & $75 \%$ & $23 \%$ \\
\hline Fort Calhoun & $41 \%$ & $16 \%$ & $43 \%$ \\
\hline Zion $1 / 2$ & $55 \%$ & $43 \%$ & $2 \%$ \\
\hline Rancho Seco & $25 \%$ & $51 \%$ & $24 \%$ \\
\hline Prairie Island $1 / 2$ & $0.5 \%$ & $92.5 \%$ & $7 \%$ \\
\hline Average: & $22.6 \%$ & $61.0 \%$ & $16.4 \%$ \\
\hline
\end{tabular}




\subsubsection{ARGON-41 RELEASES}

\subsubsection{Parameter}

The annual quantity of argon-41 released from a pressurized water reactor is $34 \mathrm{Ci} / \mathrm{yr}$. The argon -41 is released to the environment via the containment vent when the containment is vented or purged.

\subsubsection{Bases}

Argon-41 is formed by neutron activation of stable naturally occurring argon-40 in the containment air surrounding the reactor vesse1. The argon-41 is released to the environment when the containment is vented or purged. Table 2-40 provides a summary of available data and gaseous argon-41 releases from operating PWR's. The information reported by the licensees is not sufficiently detailed to correlate reported argon-4l releases with plant size and plant operating parameters. However, the average argon-41 release is estimated to be 34 curies per year. 
TABLE 2-40

SUMMARY OF ARGON-41 RELEASES FOR OPERATING PWR's FOR 1973-1978 (Ci/yr per reactor)

Reactor Name

Yankee Rowe

Haddam Neck

Ginna

Point Beach $1 / 2$

H. B. Robinson

Surry

D. C. Cook

Turkey Pt. 3/4

Oconee $1 / 2 / 3$
Year

1974

1975

1976

1977

$1978(1 / 2 \mathrm{yr})$

1973

1977

1978 ( $1 / 2 \mathrm{yr})$

1975

1976

1973

1974

1975

1976

1977

1978 (1/2 yr)

1975 (1/2 yr)

1976

1977

$1978(1 / 2 \mathrm{yr})$

$1974(1 / 2 y r)$

1975

1976

1977 (1/2 yr)

$1978(1 / 2 \mathrm{yr})$

1974

1975

1976

1977

$1974(1 / 2 \mathrm{yr})$

1975

1976

1977

$1978(1 / 2 \mathrm{yr})$
Release

0.85

0.93

0.3

0.49

0.47

0.044

0.08

0.041

5.8

0.19

17.6

16

208

31

9.2

13.3

16.2

15.4

23.1

46.2

15

0.32

9.15

16.5

19.7

26

51.3

39.4

45

59.5

42

118

8.1

19.9 
TABLE 2-40 (continued)

SUMMARY OF ARGON-41 RELEASES FOR OPERATING PWR's FOR 1973-1978 ( $\mathrm{C} i / \mathrm{yr}$ per reactor)

Reactor Name

Fort Calhoun

Palisades

Zion $1 / 2$

Prairie Is 1 and $1 / 2$

Kewaunee

Three Mile Island 1

Calvert Cliffs

Rancho Seco
Year

1975

1976

1977

1978 (1/2 yr)

$1978(1 / 2 \mathrm{yr})$

$1978(1 / 2 y r)$

1975

1976

1977

1978

$1976(1 / 2 \mathrm{yr})$

$1978(1 / 2 \mathrm{yr})$

$1975(1 / 2 \mathrm{yr})$

1976

1977

$1978(1 / 2 \mathrm{yr})$

$1976(1 / 2 \mathrm{yr})$

1977 (1/2 yr)

1977

1978 (1/2 yr)
Release

8.2

2.2

2.3

0.27

0.01

24.8

1.3

21

31.8

13.5

30

5.9

50

12

66

46.5

2

3.1

9.8

1.8

* All data provided by the semiannual effluent release reports and the annual operating reports for each PWR listed. 


\section{CHAPTER 3. INPUT FORMAT, SAMPLE PROBLEM, AND FORTRAN}

LISTING OF THE PWR-GALE CODE

\subsection{INTRODUCTION}

This chapter contains additional information for using the PWR-GALE Code. Chapter 1 of this report described the entries required to be entered on input data cards. Section 3.2 of this chapter contains sample input data and an explanation of the input to orient the user in making the entries described in Chapter 1.

Section 3.3 of this chapter contains a listing of the input data for the sample problem and the resultant output. Section 3.4 contains a discussion of the nuclear data library used and a FORTRAN listing of the PWR-GALE Code.

\subsection{INPUT DATA}

This section contains (a) an explanation of the input used in the sample problem and (b) input coding sheets for the sample problem.

\subsubsection{EXPLANATION OF THE INPUTS FOR THE SAMPLE PROBLEM}

Only the inputs for the GALE code runs for the sample probleril that are not obvious are explained:

Condensate demineralizer regeneration time (days)

Input - 8.4 days

Put this input in card 10 in the appropriate field allotted for this input.

\section{Basis}

The sample problem assumes eight condensate deep beds, one of which is spare in parallel with no ultrasonic resin cleaning. The regeneration time for a bed is therefore $7 \times 1.2$ days $=8.4$ days.

The liquid waste inputs are based on assuming the following:

A. Waste Generation Rates and Effective PCA Fractions

Waste Type

Shim Bleed

Equipment Drains

Pump seal leakage

Pump seal leakage (Table 2-26)
Ga1/day

1440
PCA Fraction

Code applies the

CVCS DFs internally 
A. Waste Generation Rates and Effective PCA Fractions (Cont'd)

Waste Type

Other primary coolant leakage

from miscellaneous sources inside the containment (Table 2-26)

Total equipment drain wastes

Clean Wastes

Primary coolant equipment drains (Outside containment)

Spent fuel pit liner drains

Primary coolant sampling system drains (segregated from secondary coolant samples)

Total Clean Wastes

Dirty Wastes

Primary coolant equipment Reactor containment cooling system Auxiliary building floor drains

Secondary coolant sampling system drains

Total Dirty Wastes

Regenerant Wastes

Condensate demineralizer rinse and transfer solution (secondary system wastes)
Gal/day

PCA Fraction
1.67

0.97 effective 
B. Available Equipment for Liquid Wastes Processing (Cont'd)

\begin{tabular}{|c|c|c|}
\hline Equipment & Number & $\begin{array}{c}\text { Capacity } \\
\text { (Each) }\end{array}$ \\
\hline $\begin{array}{l}\text { Resin and transfer solution receiving tank } \\
\text { (To collect secondary system condensate } \\
\text { demineralizer resin and transfer solution) } \\
\text { clean waste monitor tank } \\
\text { (For processed shim bleed, equipment drains } \\
\text { and clean wastes) } \\
\text { Dirty waste monitor tank } \\
\text { Secondary waste monitor tank } \\
\text { (For processed regenerant wastes and } \\
\text { secondary system condensate demineralizer } \\
\text { resin and transfer solution) }\end{array}$ & $\begin{array}{l}1 \\
2\end{array}$ & $\begin{array}{l}10,000 \mathrm{gal} \\
10,000 \mathrm{gal}\end{array}$ \\
\hline $\begin{array}{l}\text { Recycle feed demineralizer } \\
\text { (To process shim bleed and equipment drains } \\
\text { and located upstream of the recycle holdup } \\
\text { tank) } \\
\text { Recycle evaporator condensate demineralizer } \\
\text { Evaporator condensate demineralizer A } \\
\text { (For clean wastes) } \\
\text { Evaporator condensate demineralizer B } \\
\text { (For dirty wastes) }\end{array}$ & $\begin{array}{l}1 \\
1\end{array}$ & $\begin{array}{l}50 \mathrm{GPM} \\
50 \mathrm{GPM} \\
50 \mathrm{GPM}\end{array}$ \\
\hline $\begin{array}{l}\text { Secondary waste evaporator condensate } \\
\text { demineralizer (To process regenerant wastes) }\end{array}$ & 1 & 50 GPM \\
\hline $\begin{array}{l}\text { Secondary waste demineralizer } \\
\text { (To process secondary system condensate } \\
\text { demineralizer resin and transfer solution) } \\
\text { Steam generator blowdown demineralizer } \\
\text { (To process steam generator blowdown) }\end{array}$ & 2 in & $50 \mathrm{GPM}$ \\
\hline $\begin{array}{l}\text { Recycle evaporator } \\
\text { (For processing shim bleed and equipment drains) } \\
\text { Radwaste evaporator } \\
\text { (For processing dirty wastes and clean wastes) } \\
\text { Secondary waste evaporator } \\
\text { (For processing regenerate wastes) }\end{array}$ & 1 & $30 \mathrm{GPM}$ \\
\hline $\begin{array}{l}\text { Additional Notes about Liquid wastes } \\
\text { 1. The above list includes only the process } \\
\text { for generating the liquid waste inputs fo } \\
\text { code. For example, it does not consider } \\
\text { evaporator condensate tank, reactor maket }\end{array}$ & $\begin{array}{l}\text { equipment } \\
\text { running the } \\
\text { ch equipment } \\
\text { water storas }\end{array}$ & $\begin{array}{l}\text { assumed } \\
\text { GALE } \\
\text { as fil } \\
\text { ge tank, }\end{array}$ \\
\hline
\end{tabular}


2. Except the condensate deep bed demineralizers in the secondary system, all other demineralizers are assumed to be mixed bed and non-regenerative.

3. The processed steam generator blowdown is assumed to be totally returned to the secondary system. It is also assumed that the steam generator blowdown is 75,000 pounds/hr $(-150$ GMP $)$.

4. Secondary system condensate demineralizer rinse and transfer solution waste has not been included as input for the sample problem GALE code run for the following reasons:

a. This waste is assumed to be collected in a collection system dedicated for this waste in the sample problem.

b. Even if 100 percent of this waste is released without treatment, the release from this stream is expected to be $\leq 0.15$ percent of the total liquid effluent release. If, however, this waste is processed by the secondary waste demineralizer listed above, the release from this stream is expected to be $<0.012$ percent of the total liquid effluent release. Furthermore, it is likely that this waste will be processed and a major fraction of this processed waste will be recycled to the condensate storage system for eventual reuse in the secondary plant.

Note that if assumption a is not satisfied in any design, then the inputs for this waste should be properly integrated with the appropriate subsystem inputs (for example, the dirty waste subsystem) and the effective inputs for the combined waste system should be included for the GALE code run for that design.

5. The detergent wastes are assumed to be released without any prior treatment.

6. All the liquid waste subsystems included in the GALE code run for the sample problem have at least a two-day holdup capacity for holding up the wastes prior to processing them.

7. In vie': of what has been stated above, no additional run need be made to evaluate the liquid effluent releases; also no adjustments need be made to waste subsystem DFs for possible equipment downtime.

D. The gaseous waste inputs to the GALE code run for the sample problem are based on assuming the following:

1. There is neither continuous degassification of the full letdown flow to the gaseous radwaste system via a gas stripper nor continuous purging of the volume control tank.

2. Fill time and holdup time for gases stripped from the primary system are based on the following: 
Number of pressurized storage tanks - 4

Volume of each tank at STP - $650 \mathrm{CF}$

Design pressure for each tank - 150 psig

No recombiners

3. Containment has small diameter (8 inches) purge line and the low volume containment purge rate is 1000 CFM.

4. Containment has no internal cleanup (kidney) system.

5. Number of high volume containment purges during power operation 0 .

6. Fuel, auxiliary and containment buildings have HEPA filters and four inch charcoal adsorbers on their exhaust lines and these filter units satisfy the guidelines of Regulatory Guide 1.140. Containment building has these filters both on the low and high volume purge exhaust lines. Waste gas system has HEPA filters on its exhaust line which satisfies the guidelines of Regulatory Guide 1.140. The iodine releases via the main condenser air ejector removal system are assumed to be released without any treatment prior to their releases.

7. Steam generator blowdown flash tank exhaust is not vented directly to the atmosphere.

\subsubsection{INPUT CODING SHEETS}

Figure 3-1 shows the input coding sheets used for the sample problem.

\subsection{SAMPLE PROBLEM - INPUT AND OUTPUT}

Figure 3-2 shows printouts of the input and output for a sample problem using the PWR-GALE Code.

\subsection{LISTING OF PWR-GALE CODE}

\subsubsection{NUCLEAR DATA LIBRARY}

Calculation of the releases of radioactive materials in liquid effluents using the GALE Code requires a library of nuclear data available from the Division of ADP Support, USNRC (301) 492-7713. For convenience, the tape consists of five files, written in card image form. The contents of the five files are:

1. File 1: A FORTRAN listing of the liquid effluent code.

2. File 2: Nuclear data library for corrosion and activation products for use with the liquid effluent code. 


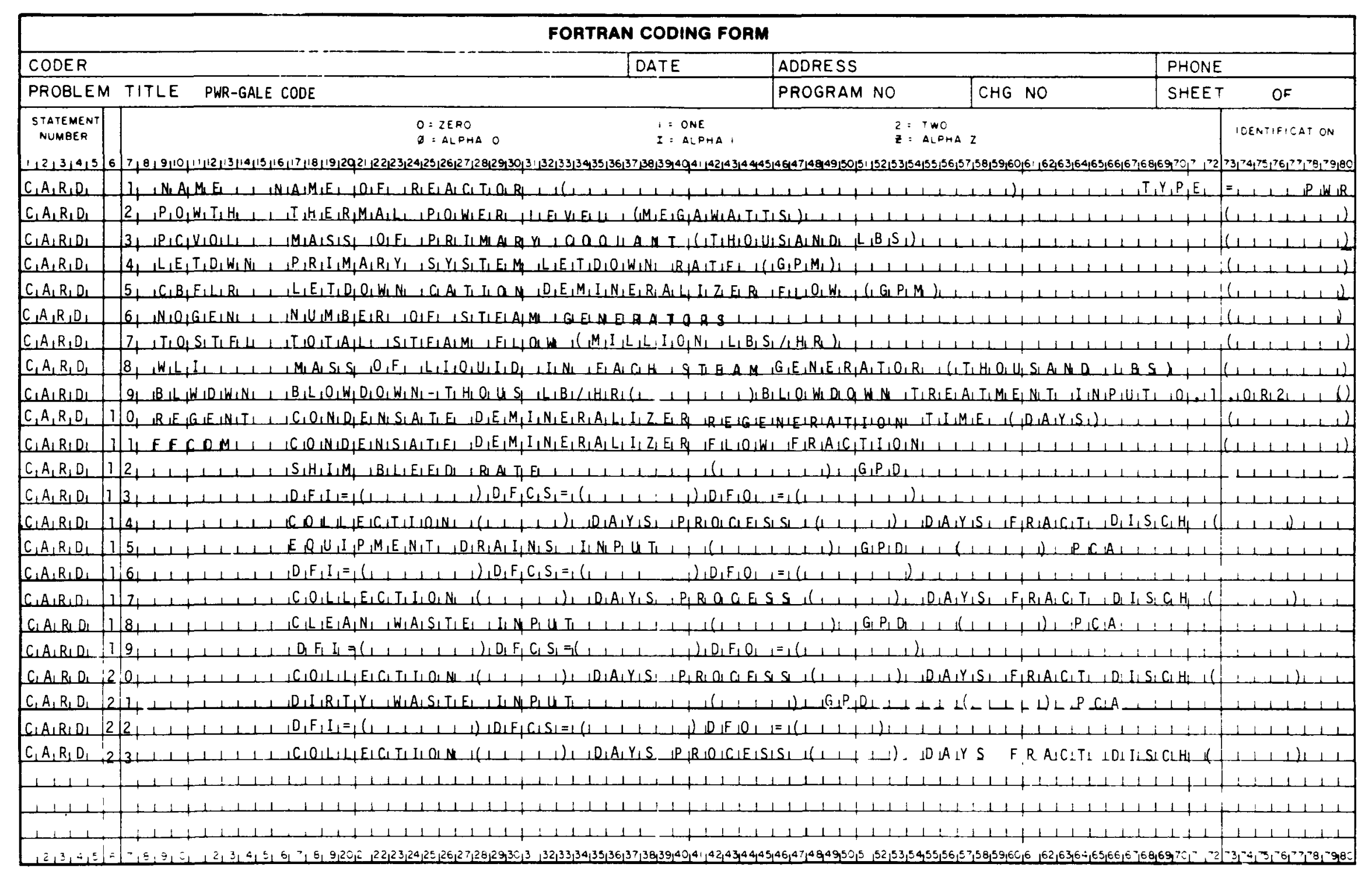




\begin{tabular}{|c|c|c|c|}
\hline $\begin{array}{l}\text { CARD } \\
\text { CARD } \\
\text { CARD } \\
\text { CARD } \\
\text { CARD } \\
\text { AARD } \\
\text { AARD } \\
\text { CARD } \\
\text { CARD } \\
\text { CARD }\end{array}$ & $\begin{aligned} & 1 \text { NAME } \\
& 2 \text { POWTH } \\
& 3 \text { PCVOL } \\
& 4 \text { LETDWN } \\
& 5 \text { CBFLR } \\
& 6 \text { NOGEN } \\
& 7 \text { TOSTFL } \\
& 8 \text { WLI } \\
& 9 \text { BLWDWN } \\
& 10 \text { REGENT } \\
& 11 \text { FFCDM } \\
& 12 \\
& 13 \\
& 14 \\
& 15 \\
& 16 \\
& 17 \\
& 18 \\
& 19\end{aligned}$ & 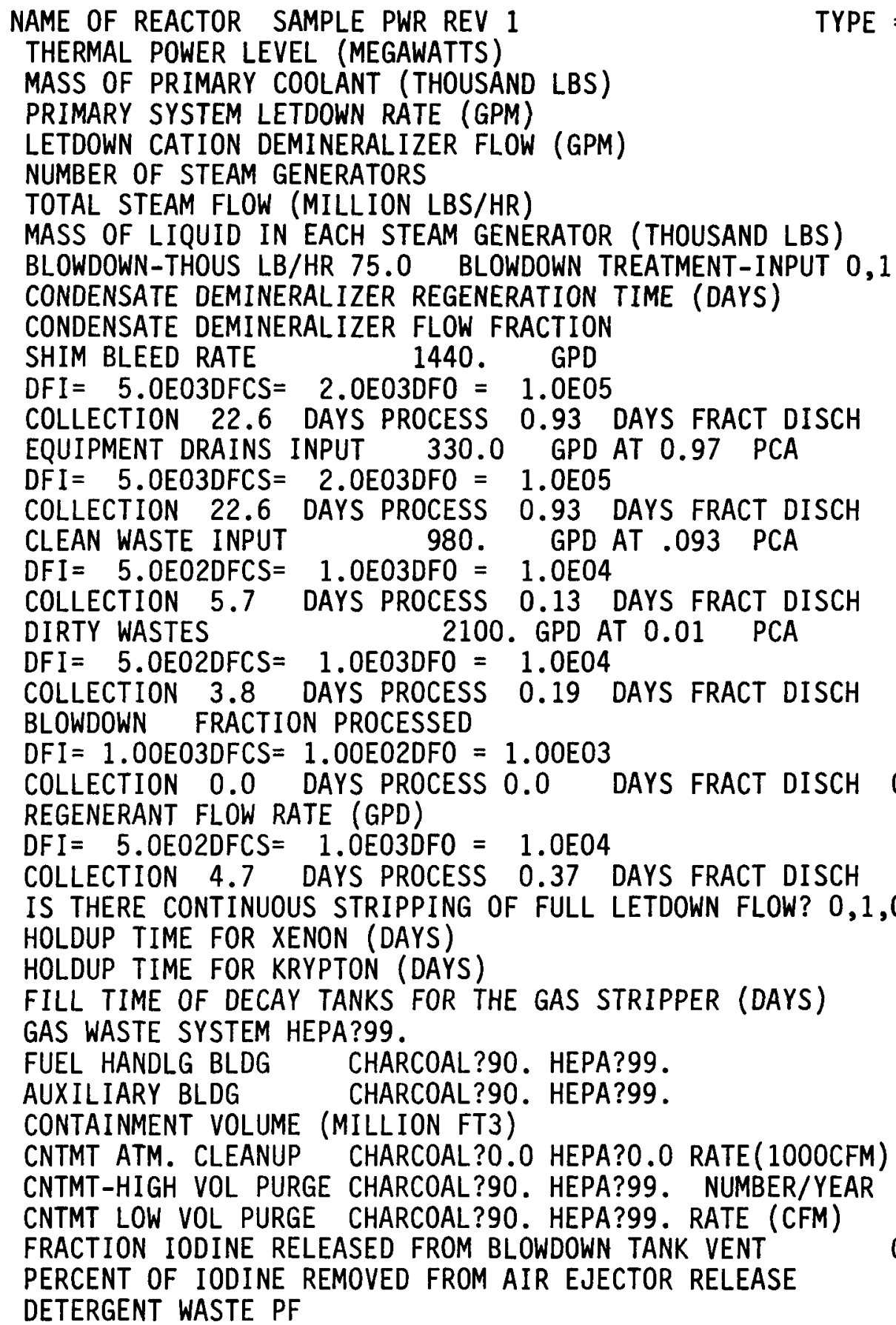 & $\begin{array}{l}=\quad P W R \\
3400 . \\
550 . \\
75 . \\
7.5 \\
4 . \\
15 . \\
112.5 \\
1,0 R 20 \\
8.4 \\
0.65\end{array}$ \\
\hline
\end{tabular}


GaMPLE PWA REV 1

IHERMAL POWEM LEYEL (MEGAMATTSI

plant Capacily factor

MASS OF PRIMARY COULANT (THOUSANU LBS,

PHIMARY SYSIEM LOTOOWN HATE (GPM)

LETDOWN CATIUN DEMIMERALIZER FLOY (BHM)

NUMAER OF STEAM GENERATURS

TOTAL STEAH ELOW (MILLION LBS/HR

WEAT GENERATUR (THOUSANU LOS) 11?.5000

GLUWDOHN RATE (TUOUSAND LAS/HR)

PHIMARY TO SECONDARY LEAK RATE RLBSINAY

75.0000
$\quad 9.0000$

CUNOENSATE UEMINGRALIZER FLOW FRACTIUN

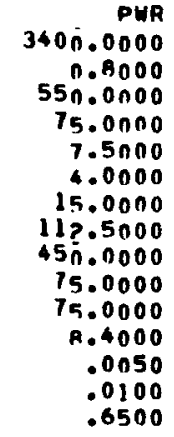

LIOUIO WASTE INPUTS

STREAM

$$
\text { FLOW RATE }
$$$$
\text { IGAL NOAY }
$$

SHIM HLEED RATE

CLEAN WASTE INPUT

DIRTY WASTES

BLOWDOWN

$\omega$ UNTREATEU BLOWDO

FRACTION FHACTION CULLECTION

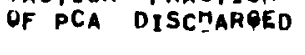

1.0000
.9700
.0930

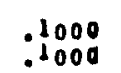

TIME
(OAYS)

OECAY
TIME
(0AYS)

$\infty$ REgENERANT SOLS
$1.44 E+03$

9. HOE.0Q

$2,10 F+03$

.0930

1000
1000

$1.0000 \quad$ a.8000

$0.000 \quad 0.000$

1.000
.100

$3.405 \bullet 03$
(DAYS)

$\$ 300$
.9300

.1300

1300
.1900

0.000

0.000

1.00E०OA

$5.00 E \cdot 02 \quad 1.00 E \circ 0$ 1.00E 1.00 N

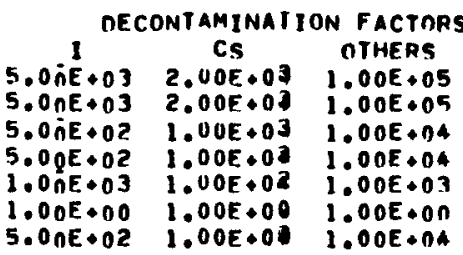

GASEOUS WASTE INPUTS

THLRE IS NOT CONTINOUS STRIPPINO OF EULL LETDWN FLOH HOLOUP TIME LOR AENON (OAYS)

HULDUP TIME FOR MRYPION CDAYS

FILL IIME OF DECAY TANKS FOR THE GAS STRIPPER (DAYSI

GAS WASTE SYGTEM PARTICULATE HELEHSE FRACTION

AUXILIARY BLUOO IOUJNE RELEASE FRACTION

CONTAINMENY YOLUGE (MILLIONET

CNTMTNCY OF CNTET QLDG HIOH VOL PUREE (TIMES/YR)

CNTMT-HTGH VUL PURGE PARTICULATE RELEASE FRACTION

CNIMT LOW VUL RUMGE RATE (CFM)

CNTMT LOW VUL PURGE TODINE RLLEASE FMACTION

PARTICULATE RELEASE FRACTION

SIEAM LEAK IU TURBINE BLDG (LBS/HR)

FHACTJON TODINE MELEASED FROM BLUWDUWN TANK VENT

PERCENT OF IUDINE REMOVED FROM ALR EUECTOH HELEASE 
NUCLIDE HALF-LIFE COOLANT GONCENTRATIONS- PRIMARY SECUNOARY BORON KS MISC. WASTES SECONUARY TUAB BLDG

ANNUAL ROLLASES TU DISCHARGE CANAL

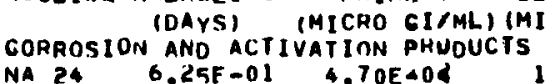

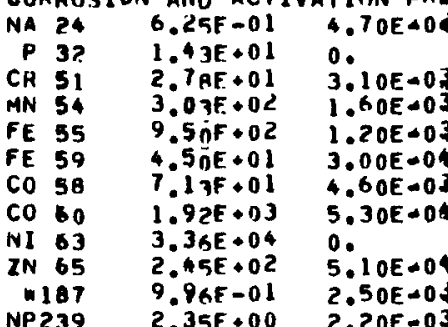

$.42 E-06$

1. $22 E-07$

$4.59 E-0 B$

$1.12 E-O B$

2. $06 \mathrm{t}-0 \mathrm{~B}$

i. Y7E -08

$8.2 t-08$
$7.90 E-O B$

FISSION PKODUCTS

SR $89 \quad 5.60 \mathrm{OE}+01 \quad \mathrm{~T} .40 \mathrm{COO} 4 \mathrm{O}$

SH 91 1.03E 04

$Y 91 M \quad 3075-02$

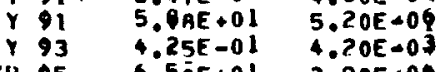

$5.34 E-09$

$345-09$
$.59 E-10$

$2.67 E-O B$

$3.16 E-09$

$1.14 E-07$

$1.50 K-08$

T NB 95 3.5nE+0

$3.90 E-09$
$2.80 E-04$

$1.03 E-08$

$1.06 E-07$

$4.70 E<07$
$7.50 E<03$

RU10.3 $3.96 E+0$

RHI $03 M \quad 3.9 M E-U 2$

RU106 3.07E 02

RH106 106 (3E-04

AGIIDM $2.57 E+02 \quad 1.30 E-03$

SHI10 $2.92 E-04$ O.

TEI29M $3.40 \mathrm{DE}+01$ i.90E 40

TE129 4.79E-02 2.40E 02

TE13IM 1.25E $\$ 00$

$1.50 E-03$

3. $46 E-06$

$4.96 E-06$

7. $30 E-09$

2. $17 E-07$

1. $36 \mathrm{E}=06$

$6.20 E-08$

$\begin{array}{rl}T E 132 & 3.25 E+00 \\ 1132 & 9.59 E-02\end{array}$

$1.70 E 403$

$2.10 E<01$

$\begin{array}{lll}1133 & 8.75 E-01 & 1.40 E-01 \\ 1134 & 3.67 E-02 & 3.40 E-01\end{array}$

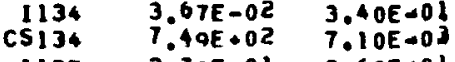

$\begin{array}{lll}1135 & 2.79 E-01 & 2.60 E<0 l \\ \operatorname{cS} 136 & 1.30 E+01 & 8.70 E<04\end{array}$

$\begin{array}{lll}\text { CS136 } & 1.30 E+01 & 8.70 E+04 \\ \text { CSI31 } & 1.10 E+04 & 9.40 E-03\end{array}$

BA137M $1.77 E-03$

BALO $1.2 \mathrm{AE}+01 \quad 1.30 E-02$

3. $15 \mathrm{Lt}-06$

$2.27 E-06$
$2.84 E-07$

$5.47 E-06$

3.79E-07

$4.67 E-07$

(CUAIES) (CUR IES) SECUNU (CIIRLES)

ADJUSTE

DETEROENT

WASTES

TOTAL

.00000

.00003

.000 ío

.00005

$.000 n 9$

(CI/YR)

(Cl/YA)

(CI/YR)

$\begin{array}{rrrrr}0.00000 & 0.00000 & 0.00000 & 0.00000 & 0.00000 \\ .00000 & .00001 & .000000 & .00001 & .00002\end{array}$

$.00114 \quad 0.00000$

.00110

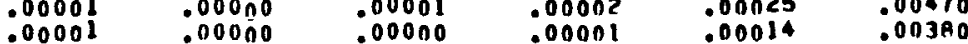

.00019

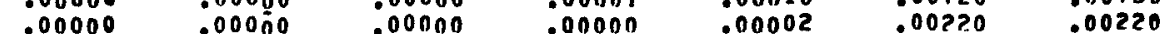

0.000020 .000000000

$.00000 \quad .00000 \quad .00000 \quad .00000 \quad .00000 \quad .00005 \quad .014100 \quad .011400$

$0.00000 \quad 0.00004 \quad 0.00000$

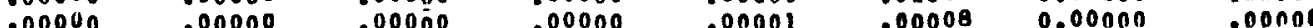

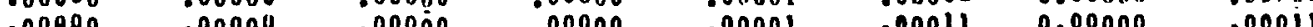

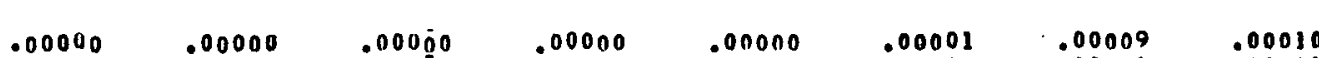

$.00000 \quad .00000$

.00000

.00000

.00000

.00000
.00000

.00000
.00050

.00000

.00000

.00000

.0000

.00000

.00000

.000000

.00000

.00000

$.00000 \quad .0000$

.00000

00002

$.000 n 0$
$.000 n 0$

.00000

.00000

.00000

.00000

.00000
.00000

.00003

.00000

.0000

.00000

.0000

.00000
.00000

$.00 n 00$

.00000

.00001

.00000

.00000

.00002

.00004

.00037

.0000

.0000

.00000

.0000

.00005

.00000

.0001

.0000

.00000

.0000

.00000

.00000

$.000 n a$

00059

.0000

0.00000

.00000

0.00000
.00000

$.00000 \quad .00000 \quad .00000 \quad .000 n 0 \quad .00100$

.000000

.00309

.00000

.00100
.00000

onjan

.00001

.00019

.00000

.00013

.00010

$.00003 \quad .00290 \quad .00000 \quad .00031$

$.00000 \quad .00001 \quad 0.000$ ño

.00050

00029

.00000

.00000

.00325

.0000

.0008

.00163

$.00003 \quad .00003 \quad .00000 \quad .00000$

$.00003 \quad .00003 \quad .00000 \quad .00000$

.00029

.00007
.00109

$.00063 \quad .00037 \quad .000$ ña

00003

.000 no

.00002

-

0000a

5. ? $1 E-09$

.00000

$.00000 \quad .000$ ñ

.0000

-10
0

.0000

.000 ño

1.50E-07

$1.37 E+01$ O.

$\begin{array}{lll}\text { CE144 } & 2.94 E+112 & 3.90 E<03 \\ \text { PRI44 } 1.20 E-112 & 0 .\end{array}$

ALL OTHERS

$6.26 E-07$

00000

0.00002

.000 ño

.00000

$+.00000$

.00001

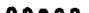

.00003

.00003

.00000

.00002

.00001

.00007

.00003

.00035

.00030

.00061

.00766

.00011

.0000

0.00000

.00002

.00006

.04429

.00313

.04226

.0060

.02122

.014.13

0000

$0.000 n 0$

0.00000

0.00000

.00110

.00006

0.00010

0,00000

.00990

$0.000 n 0$

0.00120

0.00043

0.00000

$0.000 n 0$

0.00000

0.00000

0.00000

$0.000 n 0$

$0.000 n 0$

$0.000 n 0$

.01600

.01322

0.00000

.00098
.00155

.00001

.0009

0.00000
.00023

.0001

0.00000
0.00000

.00033

$.00033 \quad 0.000 n 0$

$.00216 \quad .00972 \quad .000 \hat{1}$

.00141

.017 .31

.17331

.08975

nonol

. nOnOR

.00001

00007

.00110

00041

.00030
.00091

.00061

.0170n

-

nODOI

- nonas

oncos

-

. na600

.00010

$.0420 n$

-00n?

.02100

.00130 
TRITIUM RELEASE 200 CURIES PEH YEAR

note, .0000n InUICates that the Value IS LESS Ihan 1.0E-5.

$\frac{w}{0}$ 
IHE BMAL POWEK LEVEL (HAF.GAGATTS)

HLALIT CERACI!Y FACTOKK

MASS OF DPIMAHY (OULAIIT (THOUSAIII) LQD)

HKIMARY SYSILM I.BTUOWIS HATE. (I,PM)

LETINUWN CATIUII LEMIPIERALI IEP FI UW (GRM)

MUP.HED OF STEAM GF.MEKATINES

FUIAL SIEATH FLO (MILLIOH LHS/HH)

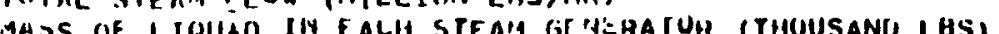

HLUWUNWA RATE (TII)ISAHO LINS/HR)

CU.HIEISATF IILMINEKALIZEH HEGT VE HATIJIN TIME (DAYS)

.65000

LIUIITO WASIF JinHUTS

\begin{tabular}{|c|c|}
\hline STKEAM & $\begin{array}{l}\text { FLUW GAIL } \\
\text { linaL_fnaYi }\end{array}$ \\
\hline $\begin{array}{l}\text { SHIM HLEED WAIE } \\
\text { EUHIPMERT NPAIHS } \\
\text { CLFAIN WHSIF IIAPUT } \\
\text { OIHTY WASIFS }\end{array}$ & $\begin{array}{l}1.44 F+04 \\
1.30 F+04 \\
0.90 F+04 \\
2.10 E+0.1\end{array}$ \\
\hline $\begin{array}{l}\text { UWROWN } \\
\text { VTHFAIEll HLONUUNAS }\end{array}$ & $\begin{array}{l}? .16 \% \cdot 05 \\
i .405 .04\end{array}$ \\
\hline
\end{tabular}

$$
\text { FHACTIUN FRACTION COL }
$$

1.0000

.0000
.0700

.0950

.0100
CULLECTIOH UE.CAY TIME IIME (UAYS) (WAYS) 2द. 6000 22.6000 5.7000 s. 1000 0.00ก 0.000
0.000 0.000
4.700
(I)AYS)

.4300
.4300

.1300

.1900

0.000

0.000

.370
DECONTAMINATION PACTORS

$5.0 \stackrel{t}{E} E+03$

$\begin{array}{lll}5.0 n E+03 & 2.005+08 & 1.00 E+05 \\ 5.0 n E+02 & 1.00 R+01 & 1.00 E+04\end{array}$

$5.00 E+02 \quad 1.00 \mathrm{C}+0, \quad 1.00 E+04$

$1.00 E+04$

$1.00 E+00 \quad 1.00 E+00 \quad 1.00 E+03$

$5.0 n E+02$ 1.0OE 00 I.OOE 104

GaseOJUS WASTF INHIIS

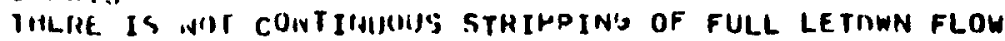
HLUW RATE THKOUGH IOAS STHIPDER ('JPM) 
gaseous release rate - CuRIES per rear

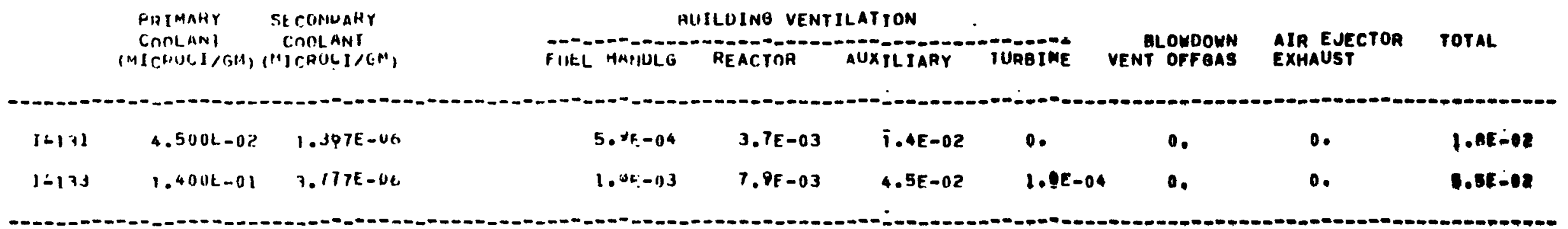

IUTAL H-i RELEASEN VIA GASEOUS PATHWAY = 1100 CI/YR

C-14 MELKagto VIA gasçoUS pathwaY $=7.3 \mathrm{Cl} / \mathrm{YR}$

AM-4I RELEASEU VIA CUNTAINMENT VENT $=34$ CI/YR 
gaseous helease hate - curtes per year

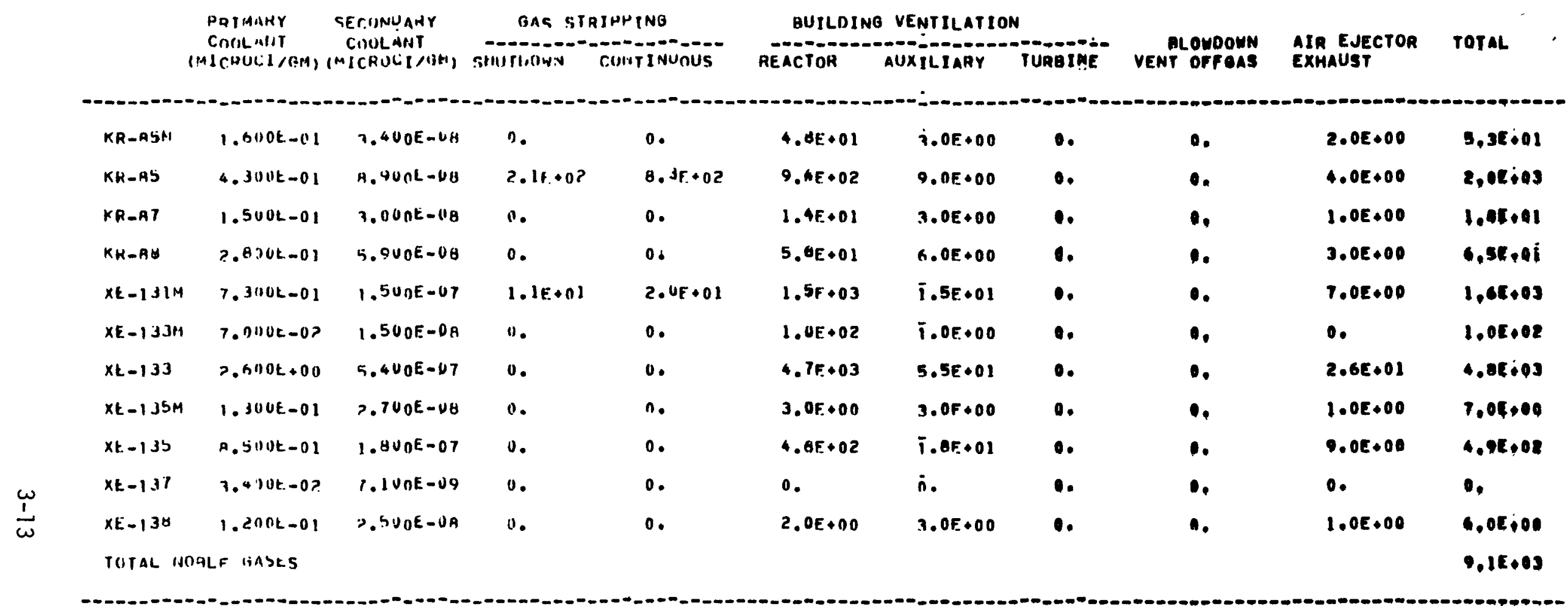

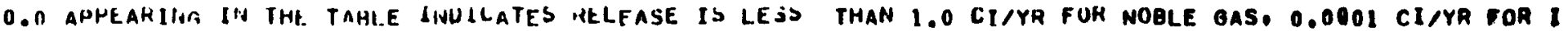




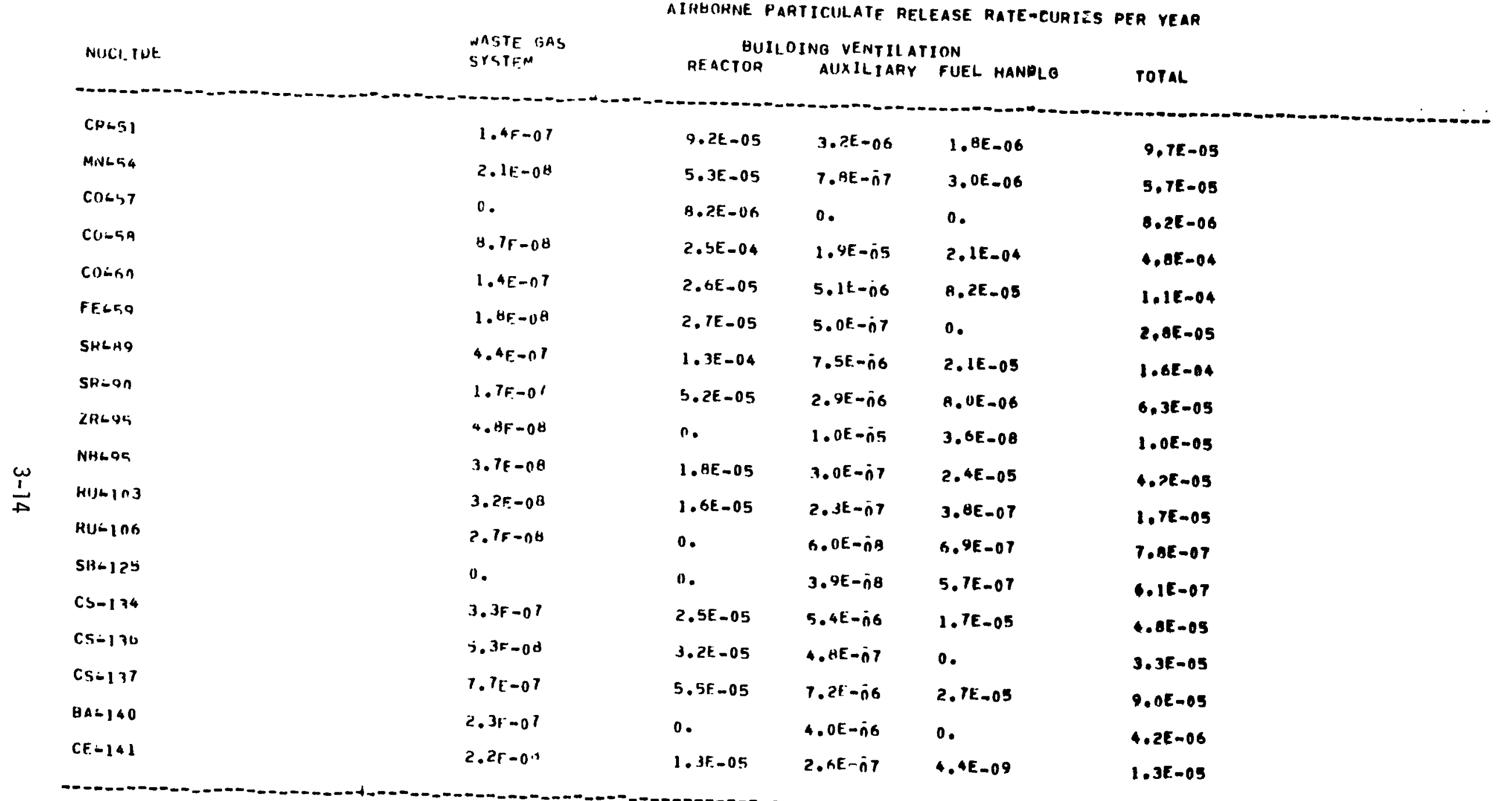


3. File 3: Nuclear data library for fuel materials and their transmutation products for use with the liquid effluent code.

4. File 4: Nuclear data library for fission products for use with the liquid effluent code.

5. File 5: A FORTRAN listing of the gaseous effluent code.

The tape is written in the following format:

$$
D C B=(\text { RECFM }=F B, L R E C L=80, B L K S I Z E=3200)
$$

Use of the tape requires two data cards in addition to those described in Chapter 1 containing the plant parameters. For a low enrichment uranium-235 oxide-fueled light water reactor, these cards should always contain the following data:

\begin{tabular}{|c|c|c|}
\hline Card & Column & Input Data \\
\hline 1 & $1-72$ & Title \\
\hline 1 & 75 & The value 2 \\
\hline 2 & $1-10$ & The value 0.632 \\
\hline 2 & $11-20$ & The value 0.333 \\
\hline 2 & $21-30$ & The value 2.0 \\
\hline 2 & $31-40$ & The value $1.0 \mathrm{E}-25$ \\
\hline 2 & $41-46$ & $\begin{array}{l}\text { The date (month, day, year) } \\
\text { of the calculation }\end{array}$ \\
\hline 2 & 48 & The value 1 \\
\hline 2 & 50 & The value 0 \\
\hline 2 & 52 & The value 0 \\
\hline
\end{tabular}

\subsubsection{FORTRAN PROGRAM LISTING}

Figure 3-3 and 3-4 provides the program listings for the PWR-GALE Code gaseous and liquid determinations. 
FIGURE 3-3

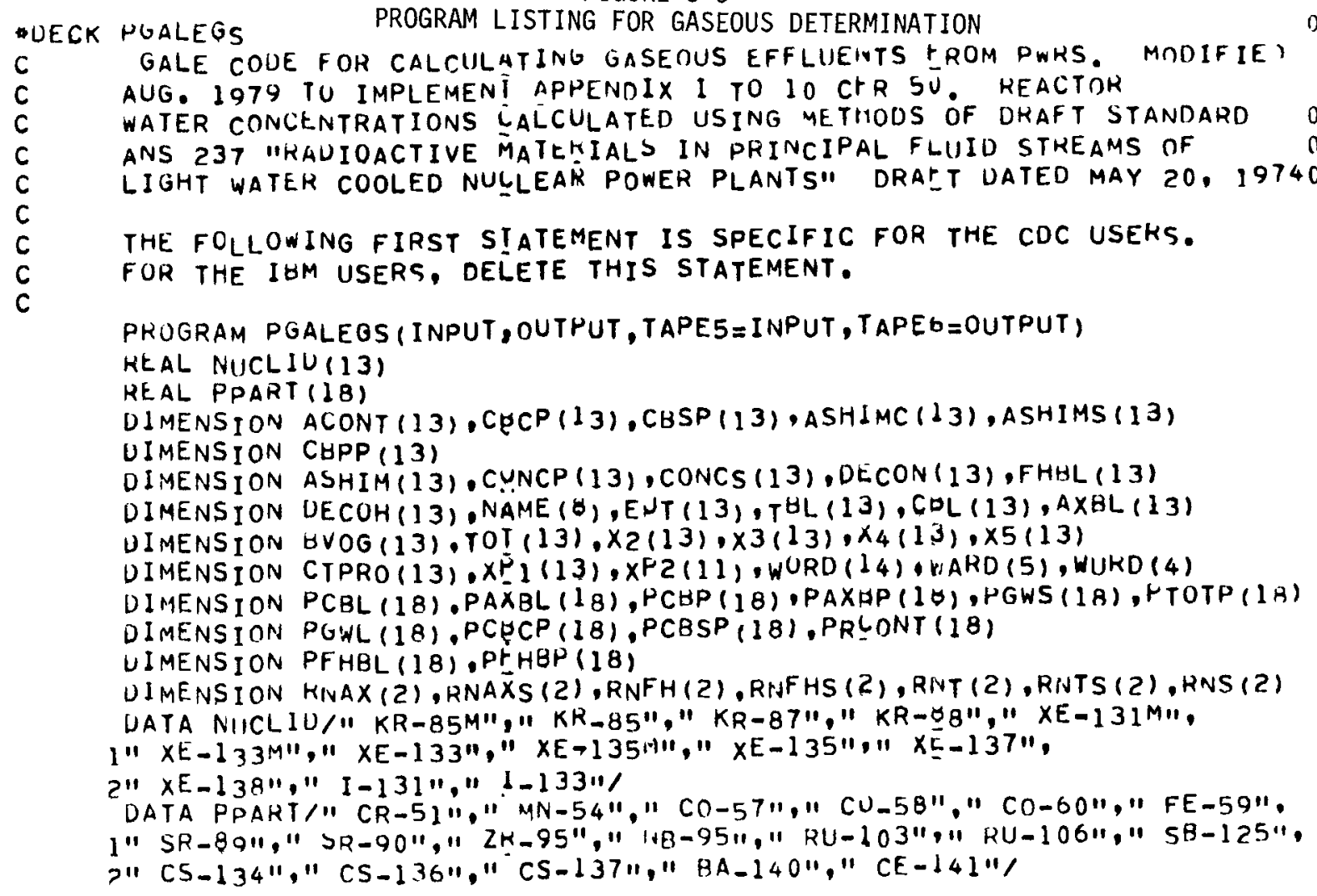

C

C

C

C

C

C

C

c

C

C

C

C

XPI AIND XPZ ARE THE PKIMAKY CUOLANT AND SLCONDARY COOLANT CONCEATRATIUNS, RESPLLTIVELY (MICROCI/GM) •

DATA XP1/1.6E-1,4.3E-1,1.SE-1,2.8E-1,7.3E-1.7.0E-2,2.6E+0.1.3E-1.8 $1.5 E-1,3,4 E-2,1,2 E-1,4,5 E-2,1.4 E-1 /$

DATA $X P 2 / 3,4 E-8,8,9 E-4,3,0 E-8,5,9 E-8,1,5 E-7,1.5 E-8,5,4 E-7,2,7 E-8,1$ $1.8 E-7.7 .1 E-9.2 .5 E-8 /$

DECAY CONSTANTS FOR THE CURRESPUNDING NUCLID $(1 / S E C)$.

DATA DECUN/4.38E-5,2.03E-?,1.52E-4,6,88E-3,6.80E-7,3,95E-6,1.52E-6 $1.7 .41 E-4.2 .09 E-5 \cdot 2.96 E-3,8.14 E-4,9.97 E-7,9.17 t-6 /$

NORMALIZEU IOBINE ANIVUAL KELEASE (CI/YR/MICROUI/GM).

DATA RNS/0.32,0.32,

DATA RNAX $10.68,0.681$

UATA RNAXS/2.5,2.5/

DATA RNFH/0.038,0.038/

UATA RNFHS/0.093.0.094/

DATA RNT/3.8E3,3.8E3/

UATA RNTS/4,2E2,4.2E2/

PAKTICILATE ANNUAL RELEASE RATE (CI/YR)

DATA PCRP $/ 9,2 E-3,5,3 E<3,8,2 E-4,2,5 E-2,2,6 E-3,6,7 E-3,1,3 E-2,5,2 E-3$, $10.0 E+0,1 . B E-3,1.6 E-3,0, O E+0,0, O E+0,2,5 E-3,3,2 E-3,5,5 E-3,0,0 E+0,1.3$ $2 E-3 /$

DATA PAXUP/3, 2E-4,7,8E-5,0,0E $0,1,9 E-3,5,1 E-4,5,0 E-5,7,5 E-4,2.9 E-4$ $1,1,0 E-3,3,0 E-5,2.3 E-5,6,0 E-6,3,9 E-6,5,4 E-4,4,9 E-5,7,2 E-4,4,0 E-4,2$.

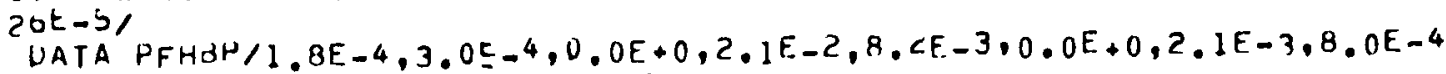
$3-16$ 


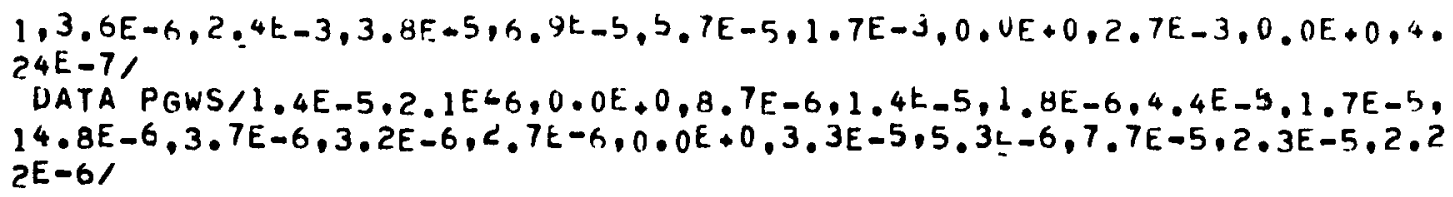

DATA PGWS/1, 4E-5,2,1E-6,0,0E,0,8,7E-6,1,4E-5,1.8E-6,4,4E-5,1,7E-5, $14,8 E-6,3,7 E-6,3,2 E-6,<, 7 E-6,0,0 E+0,3,3 E-5,5,3 L-6,7,7 E-5,2,3 E-5,2,2$

C

\section{BUILT-IN PAKAMETERS}

OPFRA $=\overline{0} .80$

$A \cup X L R=160$.

$E M=2.0$

GENL $=75$.

CLFNG $=0.03$

CLFI $=8.0 E-6$

PURTIM $=16$.

C

$T B L K=1700$.

AFPTEG $=0.0$

READ $(5,1000)$ NAME, TYPE

Oก18RO

WRITE $(6.1440)$

WRITE $(6,1000)$ NAME, TYPE

HEAD (5,1010)WORD, POWTA

WRITE $(6,1010)$ WORO, PON I H

WHI TE $(6,1020)$

READ $(5,1010)$ WORD, PRIVUL

WRITE $(6,1010)$ WORD, PRIVOL

KEAD $(5,1010)$ WORD, DEMIFL

WRITE $(6,1010)$ WORD, DEMIFL

REAO (5.101U)WORD, CHFLR

WRITE $(K, 1 U 1 U)$ WORO, CBFLR

READ $(5,1010)$ WORD, GEN

WRITE $(6,1010)$ WORD, GEN

READ (5.1010)WURD. TOSTEL

WRITE $(6,1010)$ WORO, TOSTFL

$K E A D(5,1010)$ WORD, WLI

WRITE $(R, 1010)$ WORD, WLI

$W L I=G E N \backsim W L I$

READ $(5,1040)$ THD, KFNRT

$0 \pi 46 n 0$

WRI TE $(6,1050)$ TRD

IF (KFART.EQ.0)FNRTSC $=0.99$

IF (KFNRT.EQ.1) FNRTSC 50.9

IF (KFNRT.EQ.2) FNRTSC $=1.0$

READ $(5,1010)$ WORD, REGE!YT

C

WRITE $(6,1010)$ WORD, REGENT

HEAD DATA FUR LIOUIO INFOKMATION

004740

$\operatorname{READ}(5,1010)$ WORD , FFCDM

004760

WRI TE $(6,1010)$ WORD, FFCDM

READ (5,1060) WARD, SBLUR

$C W A=1 \cdot \overline{0}$

READ $(5,1070)$ DF ICW, DFCSCW, UFCW

004820

READ (5.1080)TC,TSTORC \&CWFO

WRITE $(6,1090)$

WRITE $(6,1100)$

WRITE $(6,1110)$ WARD, SBLUR, CWA, CWFU, TC, TSTORC, DF ICW, DFCSCW, DF CW

HEAD $(5,1) 20)$ WARD, EDFLK, EDA

KEAD $(5,1010)$ OF IED, DFC $S E D, U F E D$

READ $(5,1080) T E, T S, E D F$

WHITE $(G, 1110)$ WARD, EDFLH, EUA, EUFD, TE, TS, OF IED, UFCSED, OFED

HEAD $(5,1120)$ WARD, OWFLK, DWN

HEAD $(5,1070)$ DF IDW, OFCSON, UFDW 
KEAD $(5,108 Q) T O, T S T O R D, D W F$

WHITE $(6,1110)$ WAPD, DWF LR, OWA, OWFD, TD, TSTORN, DF $\triangle D W$, DFCSDW, DFDW READ $(5,1120)$ WARD, DWFL2, BNR

HEAD (5,1070) DF 10?, DFC $>02, N F D 2$

READ (5, 1080)T2,TSTOR2,DWF 2

WRITE $(6,1110)$ WARD, DWFL2, DW2, DWF2, T2, TSTORL, DF \&D2, DFCSD2, DF D2

READ (5.1130) BDTFR

READ 15.1070$)$ DF ICM,DFCYCM, DFCM

READ $(5,1080)$ TCM, TSTORE, CMED

READ $(5,1130)$ RGWFR

READ 10,1070$)$ OFIRG, DFCSRG, OFRG

READ $(5,1080)$ TRG,TSTORR, RGFD

IF (TBD.EQ.0.0) GO TO 30

$B D F R=T R D=1.0 E 3 * B D T F R / 0.3476$

WKITE $(6,1140)$ BDFR, CMFU, TCH, TSTORB, OF ICM, DF CSCM, DFCM

BUFR $=T B D * 1$. UE 3 \&ABS $(1$. FBDTER $) 10.3476$

WRITE $(6,1150)$ BDFR

IF (FFCDM.EQ.0.0) GO TU 50

30 IF (REGENT.EQ.0.0) GO TO 40

WRITE $(6,1160)$ RGWFR, RGFD OTRG, TSTURR, DF IRG, NFCSRG, DFRG

GO TO 50

$40 R G W F=n+0$

WHITE $(6,1160)$ RGWFR, RGED,TKG, TSTORR, OFIRG, WFCSKG, DFRG

C

C

READ DATA FOR GAS INFURMATION

50 WKITE $(6,1170)$

READ $(5,1180) K G T R W T$

IF (KGTRWT.EQ.0) GO TO 70

GTRW $=(D E H I F L-S B L O R / 1440.) / D E M I F L$

IF (KGTRWT.EQ.2) GO TO 60

WKITE $(6.1190)$

$G O$ TO BO

$G T R W=0.25 * G T R W$

WKITE $(6.1200)$

GO TO Rn

$70 \quad G T R N=0.0$

WRITE $(6,1210)$

BO SRB $=G T R W \otimes U E M I F L+(S B L U K+E U L L R) / 1440$.

WRITE (, 1220$)$ SRB

READ $(5,1010)$ WORD, TAUI

WRITE $(6,1010)$ WOHO, TAUL

READ (5,1010) WURD, TAU2

WHITE $(6,1010)$ WORD, TAUL

READ (5,) U10) WORD, TAU3

WRITE $(6,1010)$ WORD, TAU3

WRITE $(6.1230)$

GWPRF $=1.0$

$A X I R F=1.0$

AXPRF $=1.0$

$C H I R F=\overline{1} .0$

CHPRF $=1.0$

CLIRF $\equiv 1.0$

$C L P R F=1.0$

F.HIRF $=1.0$

FHPRF $=1.0$

CAIRF $=1.0$

CAPRF $=1.0$

READ $(5,1250)$ WURD, GWHRE

IF (GWHRE.UT.0.0) GWPRF ₹1.0-GWHKE/100.

WRITE $(6,1260)$ WURD, GWPHF

KEAD (5.1270) WARD, FHCHKE, F UHRE

IF (FHCHRE.GT , 0.0) FHIR $=1.0-F H C H R E / 100$. 
IF (FHHRE _ (2T . 0.0) FHPRF ₹1.0-FHHRE/1000

WRITE (, 1200$)$ WARD , FHITF, F HPHF

KEEAD $(5,1270)$ WARD, AXCHK̈E, AXHRE

IF (AXCHRE.GT 0.0) AXIRE $=1.0-A X C H R E / 100$.

IF (AXVRE.UT 0.0.0) AXPRF ₹ 1.0-AXHKE/100.

WRITE $(6,1280)$ WARD, AXIKF, AAPRF

READ $(5,1010)$ WORD, CONVUL

WRITE $(6,1010)$ WORD, CONVOL

WRITE $(6,1290)$

KEAD $(5.1370)$ WARD, CACHKE, CAHRE, CFM

IF (CACHRE. GT .0.0) CAIRE = I.0-CACHRE/100.

IF (CAHRE.GT,0.0) CAPRF $\$ 1.0-C A H R E / 100$.

IF (CFM.EQ.0.0) GO TO YO

$K I D=1$

WRITE $(6,1300)$ CFM, PURTLM

$90 \quad K I D=0$

GO TO 100

WHITE $(6,1310)$

100 IF (FFCDM.GT.0.0) GO TU 110

WRITE $(6,1320)$

GO TO $j 20$

$110 \quad F I B C D=1.0-F+C D M$

WRITE $(6,1330)$ FIBCD

120 IF (TBD.E(1.0.0) GO TO 130

CUN $=0.01$

WRI TE $(6,1340)$ CON

GO TO 140
COIN $=1.0$

WRITE $(6,1340) \mathrm{CON}$

140 READ $(5,1350)$ WAHD, CHCHKE, CHHKE, EIIP

IF (CHCHRE.GT . 0.0) CHIR $=1.0-C H C H R E / 100$.

IF (CHHQE.GT . 0.0) CHPRF $\bar{\nabla} .0$-CHHRE/100.

$E N=2.0+E N P$

WKITE $(6,1360)$ EN

WRITE $(6,1200)$ WARI), CHIHF, CHPRF

READ $(5,1310)$ W'ARD . CLCHKE, CLHRE, PNUV 1

IF (CLCHRE.GT,0.0) CLIKI =1.0-CLCHKE/100.

IF (CLHRE . GT . 0.0) CLPRF $\$ 1.0-C L H K E / 100$.

IF (PNOVI.LT.1.0) GO TU 150

WRITE $(6,1380)$ WARD, PNOV I, WARD, CLIRF, CLPRF

GO TO 160

150 WRITE $(6,1390)$

160 WRITE $(6,1400)$ TALK

$R E A D(5,1010)$ WURD, FVN

WRI TE $(6,1010)$ WORD, FVN

$\operatorname{KEAO}(5,1010)$ WORD, FEJP

, FEJP $=1.0-F E J P / 100$.

I WRITE $(6,1010)$ WORD, FEJP

READ $(5,1010)$ WORD, PFLAUNN

c

IF (PFLALIN.LE,0.0) WRIIE (E.1430)

c CUNVERSION UF UNITS

TOSTFL $=$ TOSTFL $* \overline{1000000}$

$W L I=W L I \$ 1000$.

CUNVOL=CUNVOL $\$ 1000000$,

CFM $=C F M * 1000$.

$T B D=T B D \otimes 1 E 3$

$P K I V O L=P R I V O L \perp E 3$

$\triangle E M I F L=D E M I F L 500.53$

$S B L D R=S R L U R \otimes .3476$

$E L F L R=F D F L R \$ .3476$

0,6210

0,6220

0 ก6 6230

006240

0 ก 6260

$0 \cap 6270$

0076280

0 กิ6290

006300

0 ก6310

0 ก6 6320

$0 \cap 6330$ 
OWFLR = DWFLHA.3476

0,0340

DWFL $=D W F L 2 \$ 3476$

$0 \cap 6350$

CBFLR $=C B F L K \$ 500.53$

$0 \cap 6360$

C

H3COPW IS THE PWR TRIIIUM PRIMAKY COOLANT CONLENTRATION IN UCI/GM ONG3RO

$H 3 C O P W=1.0$

0076390

H3PRP $=0.4 * P O W T H$

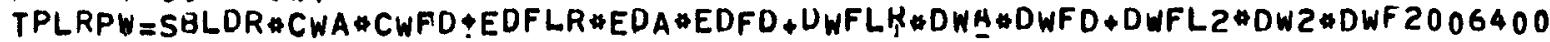

H3RLPW $=$ TPLRPWAH3COPW 3.977

IF (H3RLPW.GT .0.9*H3PREW) HQRLPW $=0.9 \% H 3 P R P W$

$H 3 R L G=H 3 P R P W-H 3 R L P W$

OIV $=10 . *(I N T(A L O G I 0(H 3 R L G))-1)$

IDIV $=$ PIV

IH3RLG = INT $(H 3 R L G / D I V+0.5):$ IDIV

IF (TAU3.EU. 0. ) TAU3 $=.01$

$S R B=S R B \$ 500.53$

$P E=365^{\circ} / T^{T} U_{3}$

$T 1=3.1557 E 7 / E N \#$ OPFRA

$T 3=3.1557 E+U 7 / P E$

$T 4=T A U 1 \$ 86400$.

$T 5=T A U_{2} \approx 86400$.

DO $190 \quad I=1,13$

$190 \operatorname{DECOH}(I)=U E \operatorname{CON}(I) * 360 \mathrm{~V}$.

DO $200 \quad 1=1.13$

$200 \quad \operatorname{CONCP}(I)=X P I(I)$

IF (POWTH.LT.3000..UR. ROWTH.6T.3800.) GO TU 210

Ir (PRI VOL.LT.5.0E5.OR,PRIYOL.GT.6.0E5) GU TO $\angle 10$

IF (UEN IFL.LT.3.2E.4.OR,DEMIFL. UT.4.2E4) 6O TO $\angle 10$

IF (SBLDR.LT.250..OR.SQLUR.GT.10U0.) GO TO 210

If (CBFLR.GT.7500.) GO TO 210

IF (KGTRWT.GI.0) GO TO 210

GO TO 240

210 AtPTEG $=1.0$

KNG2 = (SRLOR+DEMIFL*GTRW)/PRIVOL

006660

KHAL $2=$ (DEMIFL $\$ 0.99+0.41 * S H L D R) / H R I V O L$

006410

0,06430

006440

006450

0 กิ6460

0 กิ6470.

0064 BO

$0 \longdiv { 6 4 9 0 }$

0 กี 6500

006510

006520

$0 ก 6530$

RK2G $=161.76 \approx P O W T H / P R I V O L$

DO $230 \quad I=1,13$

IF (1.GT.11) GO TO 220

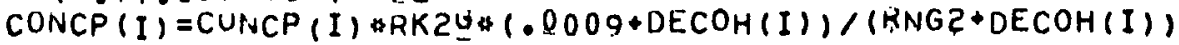

60 TO 230

$220 \operatorname{CONCP}(I)=\operatorname{CONCP}$ (I) $\# R K 2 \underline{\text { I }} *(0.067+D E C O H(I)) /(K H A L C+D E C O H(I))$

230 CONTINUE

240 IF (TBB.EQ.0.0) GO TO 2,80

C

C

PWTYPE=1.0 IS FOR PWRS WITH U-TUBE STEAM YENER_ATURS

PWTYPE $=1.0$

0 ก 6780

DO $250 \quad[=1,1]$

$250 \quad \operatorname{CONCS}(I)=X P 2(I)$

$\operatorname{CONCS}(12)=1 \cdot 8 E-6$

$\operatorname{CONCS}(13)=4 \cdot 8 E-6$

IF (AFPTEG.EQ.1.0) GO TO 300

IF (WLI.LT.4.OE5.OR.WL!.GT.5.0E5) GO TU 300

IF (TOSTFL.LT.1.3E T.OR.TOSTFL.GT.1.7ET) GO TO J0O

IF (TBQ.LT.5.OE 4.OR.TBU.GT.1.OES) GO TO 300

IF (FFCDM.GT.0.01) GO TO 300

C

60 TO 340

C HWTYPE=?.O IS FOR PWRY WITH ONCE-THROUGH STEAM GENERATOKS

C

280 HNTYPE $=2.0$

DO $290 \quad I=1,11$ 


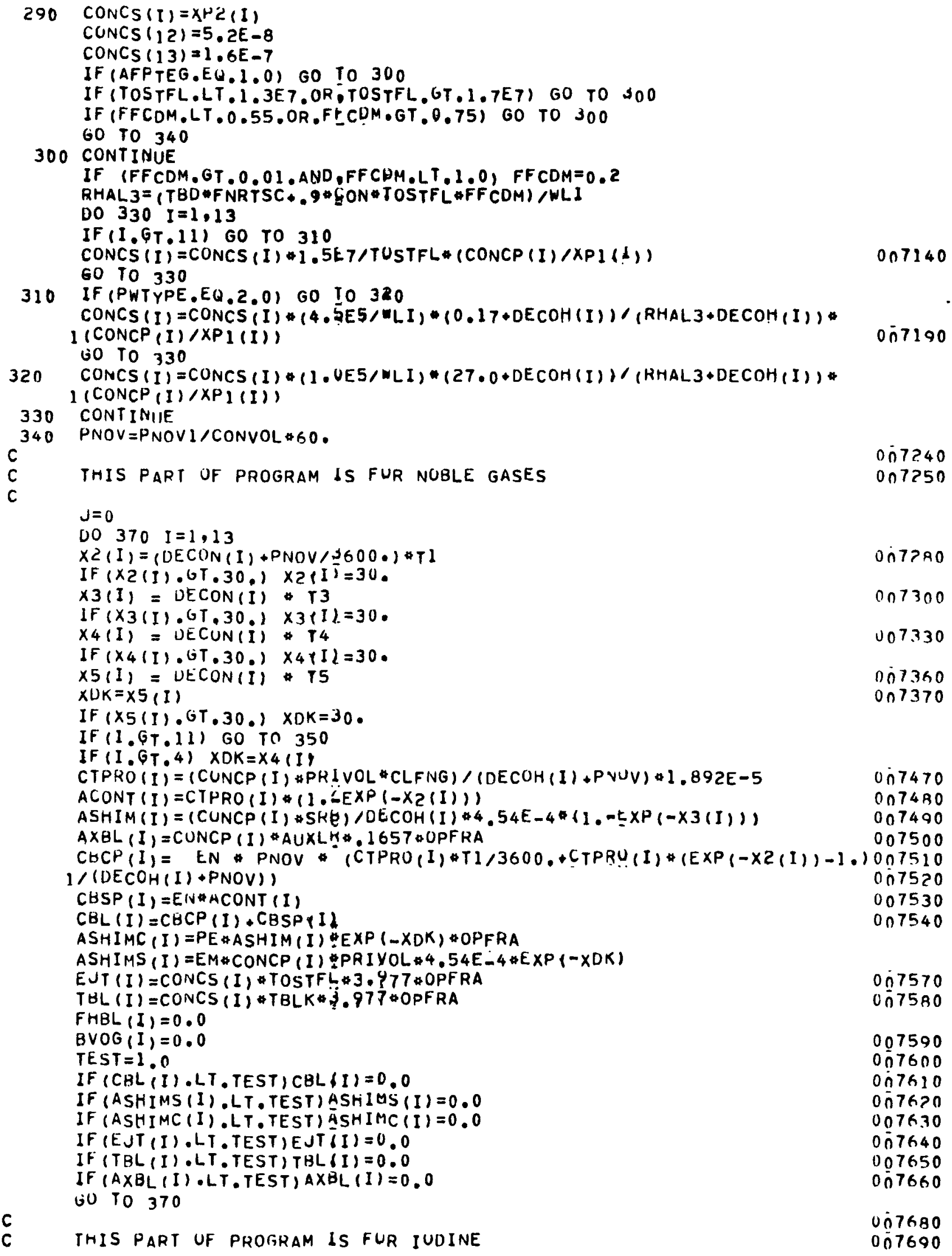


C

350 CTPRO (I) $=($ CUNCP (I) $\$ P R ! V O L * C L F I) /(D E C O H(I)+P N O V) * 1.892 E-5$

$A C O N T(I)=C T P R O(I) *(1 \cdot \operatorname{EXP}(-X 2(I)))$

$J=J+1$

$A X B L(I)=(\operatorname{RNAX}(J)+\operatorname{RNAX} \$(U)) \approx \operatorname{CONCP}(I) * A X I R F$

FHBL $(I)=(R N F H(J)+R N F H S(J)) * C O N C P(I) * F H I R F$

ASHIMC $(I)=0.0$

$A S H I M S(I)=0.0$

007740

EBCP $(I)=E N$ * PNOV (CTHRO(I)*TI/3600. CTPRU (I)*(EXP(-X2(I) -1.1007760

$1 /(D E C O H(I)+P N O V)) * C L I H F$

CBPP (I) =ENP $\triangle A C O N T$ (I, $₫$ GHIRF

$\operatorname{CHSP}(I)=\operatorname{RNS}(J) \star \operatorname{CONCP}(I) \star C U T I R F$

$C B L(I)=C B C P(I)+C B S P(I L+C B P P(I)$

EJT $(I)=1.7 E 3 * \operatorname{CONCS}(I)$ CON $\$ F E J P$

$T B L(I)=(R N T(J)+R N T S(J \downarrow) * \operatorname{CUNCS}(I) \star C O N$

$B V O G(I)=C O N C S(I) * T B D * L V N * 3.977 \approx O P F R A$

IF (KID.EQ.0) GO TO 360

DLAK $=(C F M \# 60$. CACHRE $* 0.01 * 0.7 / C O N V O L)+D E E U H(I)$

$E \times \times 2=D L A K \nleftarrow P U R T I M$

IF $(E \times X 2, G T .30). E \times \times 2=\$ 0$.

$E \times P F=E \times P(-E \times X 2)$

EXPC $=1^{\circ}:-E X P F$

ELSS $=$ CHIRF *CONCP (I) *PKIVOL*CLFI*1.892E-5/VLAK*EXPC

COL $(I)=C H P P(I) * E X P F+E L S S * E N P+C B C P(I) *(1 .-H U R I L M /(8760 . * O P F R A / E N))+$

$12 * C H I \backsim F * 0.10 * C O N C P(I) * P U R I I M /(24 . \$ 32.5) * E X P C /$ (DLAK*PURTIM)

$2+(\operatorname{CBSP}(I)-2 *$ CHIKF $0.16 *(U N C P(I) * P U R T I M /(24.32 .5))$

350 TEST $=0.0001$

If (CRL (I) . LT.TEST) $C B L(I)=0,0$

IF (EJT (I).LT.TEST)EJT (I) $=0.0$

IF $(B \vee O G(I) \cdot L T \cdot T E S T) B V U G(I)=0.0$

IF (TBL (I) .LT.TEST) TBL (I) $=0.0$

IF (AXBL (I) .L.T.TEST) AXPL (I) $=0.0$

370 CONTINIIE

CONT (FII I . T TEST) FHBL (I ) $=0.0$

007830

$M S I G=1$

IYSIG $=13$

CALL SIGF? (CBL, MSIG,NS G)

CALL SIGFZ (ASHIMS,MSIU,NSIG)

CALL SIGF2 (ASHIMC,MSIE,NSIG)

CALL SIGFZ (EJT,MSIG,NSIG)

CALL SIGF2 (BVOG,MSIG, MSIG)

CALL SIGFZ (TAL,MSIG,NSIG)

CALL SIGF2 (AXBL, MSIG,ÑSIG)

CALL SIGFZ (FHBL, MSIG,NSIG)

UO $380 \quad I=1,13$

TOT $(I)=C B L(I)+E J T(I)+I B L(I)+A X B L(I)+F H B L(1)+B X_{O} G(I)+A S H I M C(I)+A S H I$ IMS (1)

380 CONTINUE

CALL SIGF 2 (TOT,MSIG,NSIG)

WKITE $(6,1440)$

WHITE $(6,1450)$ NAME

WRITE $(6,1460)$

WHITE $(6,1560)$

WRITE $(6,1480)$

DO 385 I $=12,13$

WKITE $(6,1495)$ NUCLIDYI), CONCP (I), CONCS (I), HHRL II),

385 CONTINUE

JCBL (I), AXBL (I),TBL (I), AVOG (I),EJT (I),TOT (J)

WHITE $(6,1480)$

WRITE $(6.1510)$ IH3RLG

WRITE $(6,1440)$

WHITE $(6,1450)$ NAME

WRITE $(S, 1460)$

008140

0,07930

Oก7940

0ก7950

007960

Uก7970

OกHO?O

008040

$0 \cap 8050$

008060

0 กิKก 70

008080

Oก⿻ 090

008100 


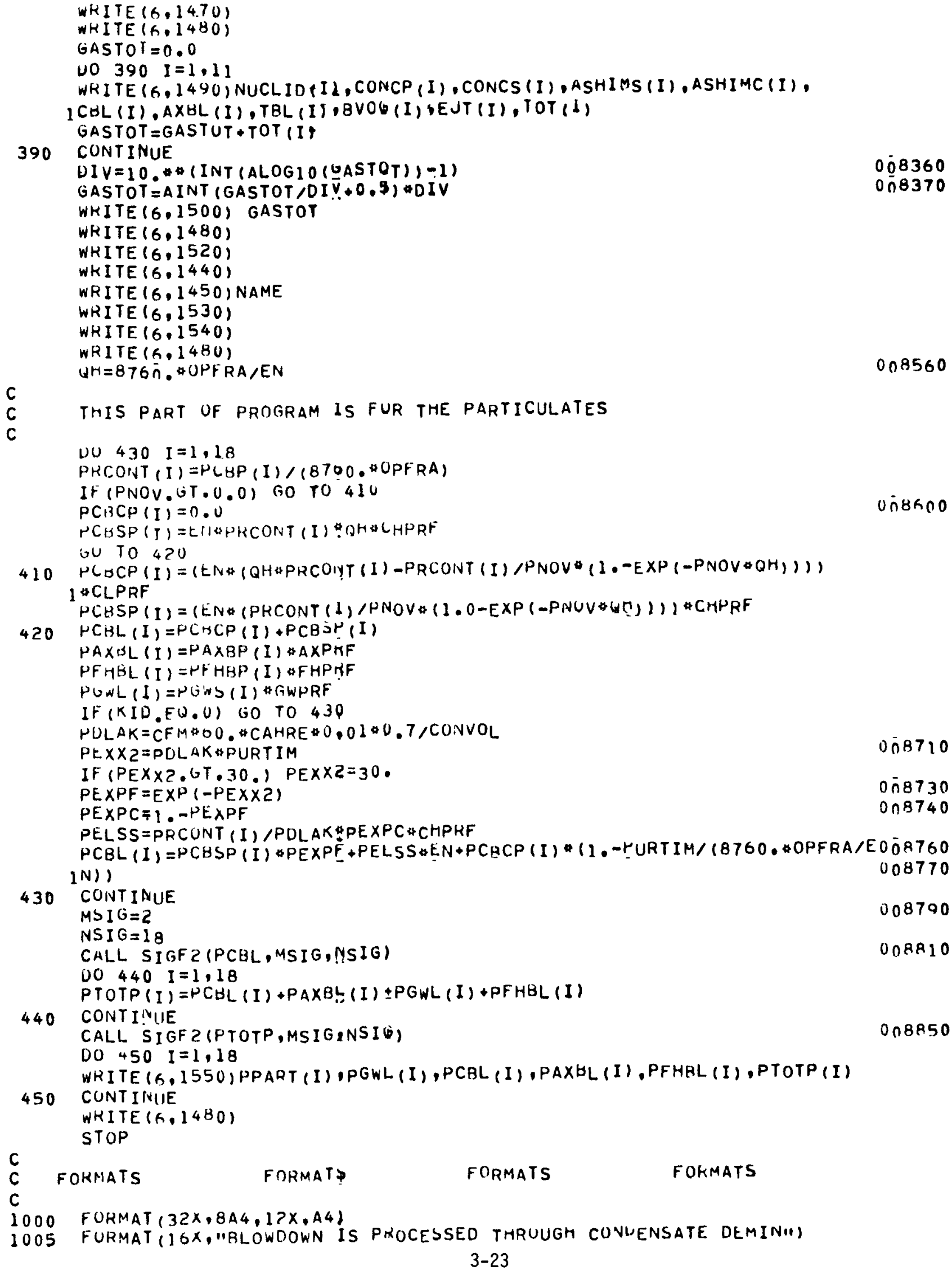


1007 FURMAT $116 x$, "RLOWNOWN IS NUT PHOCESSEO THRUUGH CUND. UEMIN.")

1010 FURMAT $(16 \times, 13 A 4, A 2, F 10,5)$

1020 FURMAT (16X, "PLANT CAPACITY FACTUK",T74,"0.80")

1030 FORMAT $116 x$, "PERCENT FÜEL ITH CLADOING DEFECTP",T74,F7.5)

1040 FORMAT $(36 x,+8,4,35 x, I$ )

1050 FORMAT (16X,"BLOWDOWN KATE (THOUSANO LES/HK)",.64X,F9.5)

1060 FORMAT $(15 X, 4 A 4, A 2,8 X, F .8 .0)$

1070 FORMAT $(20 \times, F 8.0,2(5 X, \bar{F}, 8,0))$

1080 FORMAT $(27 X, F 6,2,14 X, F Q, 2,18 \times, F 6,2)$

1090 FORMAT (1," LIQUID WASTE INPUTS")

1100 FORMAT $130 X$ TIORAGT

1 F.LOW RATE OF PCA DISCHARGED

TIME TIME",5X," DECONTAM 3"I", 8X, "CS", $8 X$, "OTHER\"1)

1110 FURMAT (2X,4A4,A2,1PE9,2,1X,4,0PF $8,4,2 x), 3(1 P E 9,2,2 x))$

1120 FORMAT $(15 X, 4 A 4, A 2,8 X, F, 8,0,7 X, F 6,4)$

1130 FURMAT $(70 X, F 10.5)$

1140 FURMAT (2X,"GLUWDOWN", $10 x, 1$ PE $, 2,11 x, F 8,3,2 x, 2(F 8,3,2 x)$, J $3(1 P E 9,2,1 X))$

1150 FORMAT (2X,"UNTREATED PLOWHOWN",1PE9.2.11X," $1.000 \quad 0.000$ $10.000 \quad 1.00 E+00 \quad 1.00 E+00 \quad \overline{1} .00 E+00111$

1160 FOKMAT(2X,"MEGENERANT SOLS ",1PEg.2,14X,OPFS.3,2X,2(F8,3,2X), $13(1 P E 9,2,1 X))$

1170 FURMAT (/" GASEMUS WASTE IRHPUTS")

1180 FORMAT $(79 \times, I 1)$

1190 FURMAT (16X."THERE IS (NTINUNUS STRIPPING OF EULL LETDOWN FLOWII)

1200 FURMAT $116 x$, "THERE IS CONTINUNUS LOW VOL PURGE OF VOL. CUNTROL TK")

1210 FORMAT (16R,"THERE IS NOT CUNTINUUUS STRIPRING OF FULL LETUWN FLO*" 1)

1220 FORMAT (16X,"FLOW RATE THAUUGH GAS STRIPPER (6rM)",19X,F9.5)

1230 FORMAT I $6 X$,"PRIMARY CUOLAIYT LEAK TO AUXILIARY HLDG (LR/UAY)".T72. $1 " 160.0000011$

1250 FURMAT (ISX, 4A4,6X,F3.V)

1260 FURMAT (16X,4A4,4X,"PAKTICULATE RELEASE FRACTIUR",6X,F 10,5)

1270 FURMAT $(16 X, 5 A 4,10 X, F 3,1,6 X, F 3,0)$

1280 FURMAT 116X,SA4,"IOOINE RELEASE FRACTIUN",11X,110.5/36X,"PARTICULAT

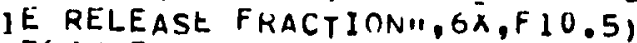

1290 FURMAT $16 X$, "FREQIJENCY OF PRIMARY COOLANT WEGADSING (TIMES/YR)",T 14 1 "2.00ñnO"/16X,"PKIMAYYY TO SECOIJUARY LEAK RATE (LB/OAY)",T72, 2"15.00000"1

1300 FORMAT (16X,"THERE IS A KIUNEY FILTER"/20X,"COWTAINMENT ATMOSPHERE

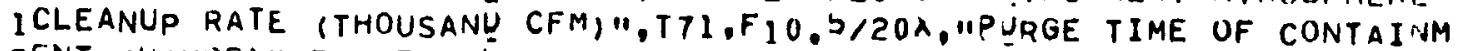
2ENT (HOURS)", TT1,F10.5)

1310 FURMAT (16X,"THERE IS INOT A KIUNEY FILTER")

1320 FURMAT (16X, "THERE IS NOT A CONDENSATE DEMINEKALIZER")

1330 FORMAT (16X,"FRACTION TODIÑE BYPASSING CONUENSÄTE DEMINERALIZER", $17 \times, T 72, F 9.51$

1340 FORMAT(16X,"IODINE PAKTITION FACTOR (GAS/LIQUID) IN STEAM GENERATO IR ",F 7.5)

1350 FURMAT $(16 x, 5 A 4,10 X, F 3,0,6 X, F 3,0,19 x, F 3,0)$

1360 FORMAT (16X, "FREQUENCY OF CNTMT BLDG HIGH YOL SURGE (TIMES/YR)", $1 T 73, F 8.51$

1370 FORMAT $116 \times, 5 A 4,10 X, F 3,0,6 X, F 3,0,14 X, F 8,2\}$

1380 FURMAT (16X,5A4,"RATE (GFM)",24X,F11,5/16X,5A4,"IUDINE RELEASE FRACT 1 ION", IIX,F10,5/36X, "PARTIEULATE RELEASE FKACT LON",6X,F10.5)

1390 FURMAT (16X, "THERE IS FOT A CNTMT BLUG LOW VOLUME PURGE")

1400 FURMAT (16X,"STEAM LEAN TO TURBINE BLDG (LOS/HK)",19X,F10.b)

1430 FURMAT ("0",25X,"THERE IS NOT AN ON_SITE LAUNDEY"1)

1440 FORMAT (IHI)

1450 FURMAT $(16 \times, 8 A 4)$

1460 FUKMAT (1HO.07X,"FASEUUS RELEASE KATE - CUMIES PER YEAR")

1470 FURMAT IIHO, 1 X, "PRIMAKY", 4X,"SECONDARY",7X,"GAS STRIPPING", $11 X$, 1 "BUILDING VENTILATION"/12x,"CUULANT", $5 x, " 6 O O L A N T ", 5 x, 21(1-" 1)$, 


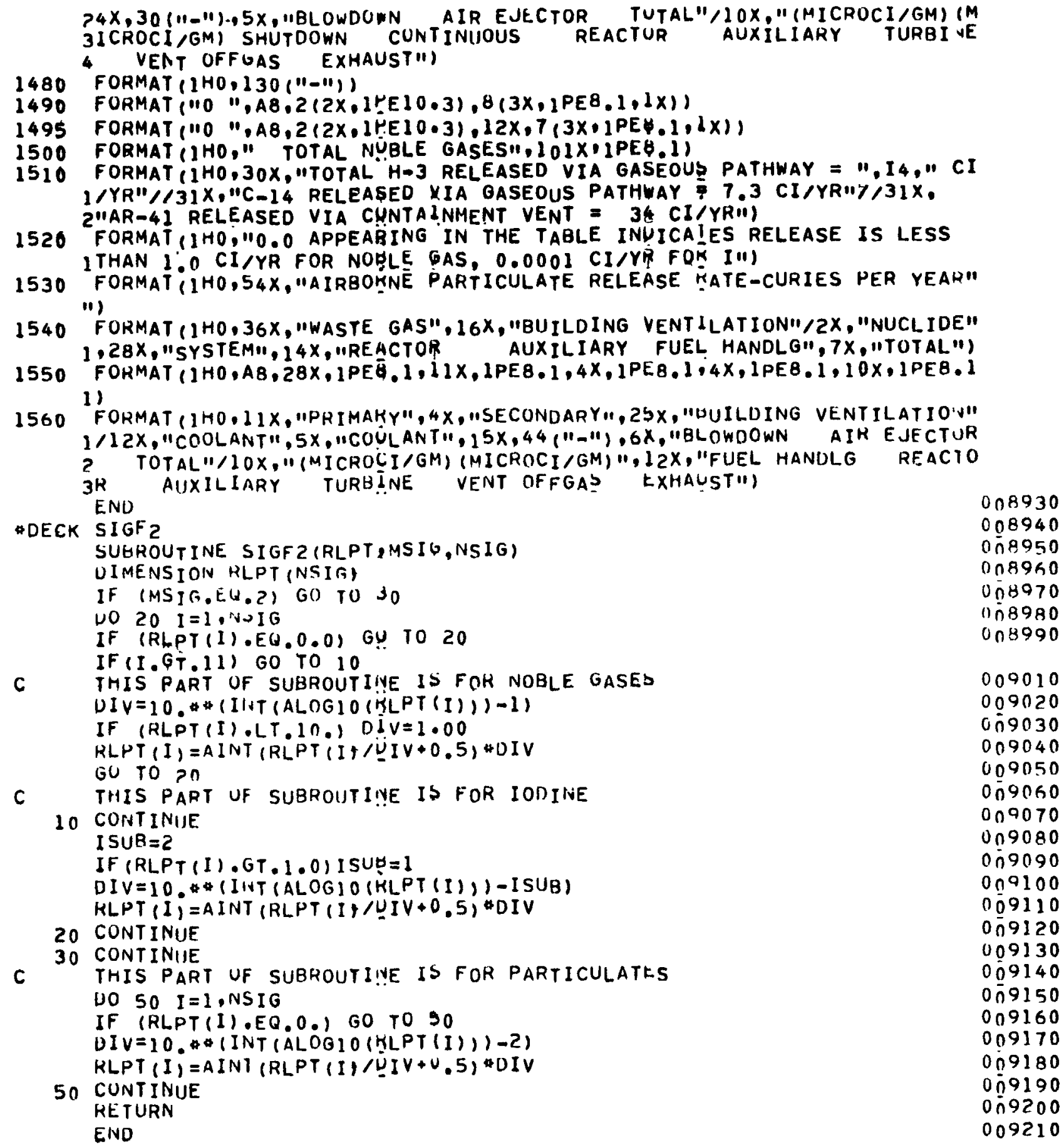


FIGURE 3-4

PROGRAM LISTING FOR LIQUID DETERMINATION

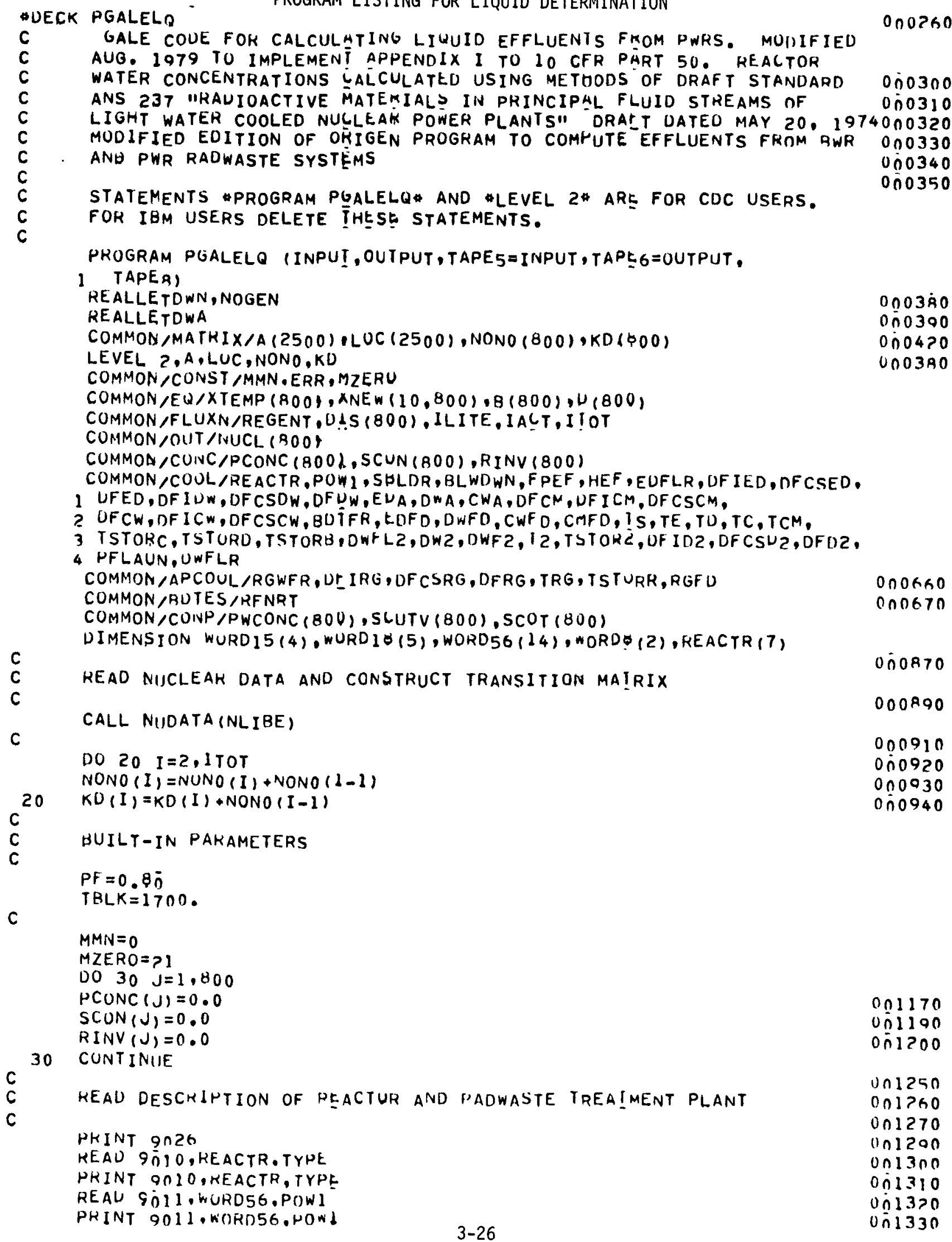




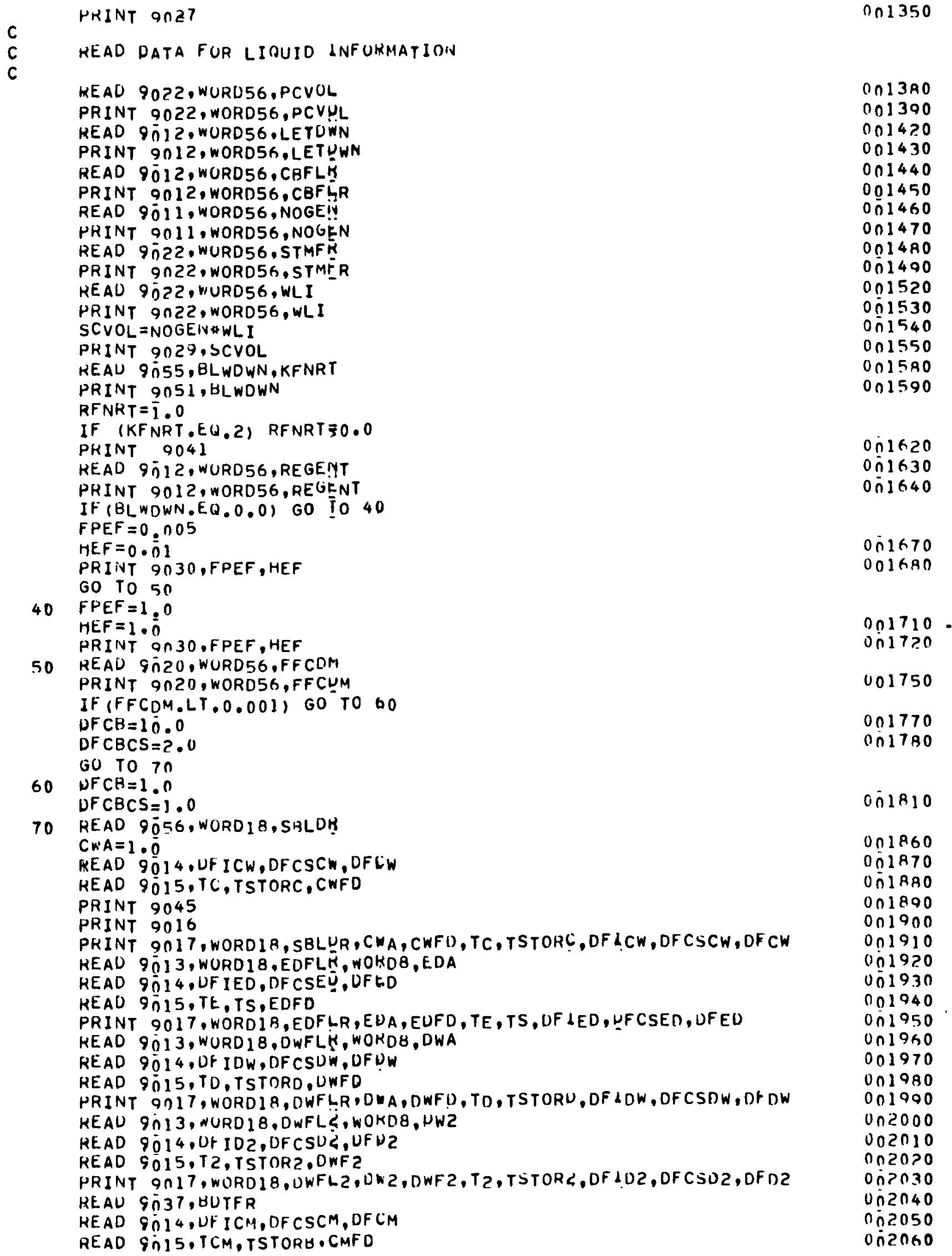


KEAO 90̄3I,KGWFR

READ 9014,OF IRG,DFCSR , OFHG

0032070

READ 9OIJ,TKG,TSTORR, KIGFO

$0 \cap 2080$

IF (BLWDWN.EQ.0.0) GO IO 15

on 2090

BUFR $=B L W D W I N$ IE $3 * R D T F R / 0.3476$

002110

PRINT 9 34, , BDFR, CMFD, TCM, TSTOKB, DF ICM, DFCSCM, NFCM

BUFR $=B L W D W N * 1,0 E 3 * A B S(1,-D D T F R) / 0.3476$

PHINT $9035, \forall D F R$

IF (FFCOM.EQ.0.0) GO TU 90

75 IF IREGENT.EU.0.01 GO IO 80

PRINT 9038,RGWFR,RGFD ITRG,TSTORR, DFIRG, DFCSRG, DFRG

$0 \cap 2120$

0,2130

002140

GO TO On

80 RGWFR $=\overline{0} .0$

PRINT $9038, R G W F R, R G F D, T R G$, TSTORR, DFIRG, DFCSRG, DFRG

0 กं2180

90 IF (KFNRT.EQ.2) GO TO 100

FNRTSO $=1.0-1.0 /(D F C M * U F C B)$

FNRTS $1=1.0-1.0 /$ (DF I CM DFCB)

FNRTSC $=1 \cdot 0-1.0 /(D F C S C M \triangle D F(B C S)$

GO TO 110

100 FNRTSO $=1.0$

FNRTSI $=1.0$

FNRTSC $=1.0$

$0 \pi 2210$

0,02240

0 กิ2 250

002260

READ DATA FUR GAS INFYYRMATION

0 in 2290

0 กิ? 300

0 ก 2320

C

PRINT $9 \cap 46$

KEAD 9 İZI, KGTRWT

IF (KGTRWT.EQ.0) PRINT 90\$3

IF (KGTRWT.EQ.1) PRINI 9052

IF (KGTRWT.EQ.2) PRINI 9075

READ 9ก12,WURD56,TAU1

PRINT 9012,WORD56, TAUI

READ 9012 , WORO56.TAU2

PKINT 9N12,WORD56, TAUद

READ 9012, WORD56. TAU3

PRINT 9012,WORD56,TAU3

002340

0 ก) 360

002370

0 กิ23 30

$0 \cap ? 390$

$0 n 2400$

Uกि2410

on 2420

002430

0 ก2 2440

GWPKF $=\overline{1} .0$

$A X I R F=1.0$

AXPRF $=1.0$

CHIRF $=1.0$

CHPRF $=1.0$

$C L I R F=1.0$

CLPRF $=1.0$

$F H I R F=1.0$

FMPRF $=1.0$

CAIRF $=1.0$

CAPKF $=1.0$

REAO 9065 , WORD 15, GWHRE

IF (GWHRE . GT . 0.0) GWPRF $=1.0-G W H R E / 100$.

PKINT 9066, WORD15, GWPKF

READ 9ÖG7, WORDIB, FHCHUTE, F OHRE

IF (FHCHPE.GT.0.0) FHI $\bar{R} F=1.0-F H C H R E / 100$.

IF (FHHRE.GT.0.0) FHPRI $=1.0-F H H R E / 100$.

AEAD 9067 , WURD 18 , AXCHËE, AX HRE

IF (AXCHRE. OT .0.0) AXIKF $=1.0$-AXCHRE $/ 100$.

IF (AXHRE.GT.0.0) AXPRF $=1.0$-AXHRE $/ 100$.

PKINT 9กGQ, WORDIB, AXIN̈F, AXPKF

READ 9ก22, WORD56, CONVÜL

PRINT 9022, WORO56, CONYOL

HEAD 9069, WURD 18, CACHIVE, CAHRE, CFM

002450

IF (CACHRE.GT.0.0) CAIYHF $=1,0-C A C H K E / 100$.

IF (CAHRE.GT.0.0) CAPRI $=1.0$-CAYHE $/ 100$. 
READ 9Ö71, WORD 1A, CHCHRE, CHHRE

IF (CHCHRE. OT .0.0) CHIKF $=1.0-C H C H K E / 100$.

IF (CHHRE.GT.0.0) CHPRE $=1.0-C H H R E / 100$.

$E N=2.0$

PRINT 9072,EN

ON2680

PKINT 9068,WORDI8,CHIKF, CUPKF

READ 9069, WORD18, CLCHKE, CLHRE, PNOV 1

IF (CLCHRE.GT.0.0) CLIRF $=1.0$-CLCHRE/100.

IF (CLHRE . GT.0.0) CLPRF $=1.0-C L H R E / 100$.

IF (PNOVI.LT.1.0) GO TY I20

PRINT 9070, WORDI8, PNOV 1 , WORD 18, CLIRF, CLPRF

GO TO 130

120 PKINT 9 Oก

130 PKINT 9064, TBLK

REAU 90̈20,WORD56,FVN

PRINT 9020,WORD56,FVN

KEAD 9020 . WORD 56,FEJ

FEJ $=1 . \dot{0}-F E J / 100$

PRINT 9020, WORD56,FEJ

READ 9020 , WURO56,PFLAUN

IFIPFLAUN.LE.0.0) PRINT 9048

PRINT 9 IO

C

C CONVERSIUN OF UNITS

C

$E U F L R=E D F L R * 48.8$

UWF LR $=D W F L R * 48.8$

C

DWFL $2=D W F L 2 * 48.8$

c

CALCULATE PRIMARY COOLANT CONCENTRATIUNS

AFPTES $=0.0$

DO $140 \quad I=1$, ITOT

$140 P \operatorname{PCONC}(I)=P W \operatorname{CONC}(I)$

POWA =POW 1

PCVOA $=P C V O L \# 1 E 3$

LETOWA = LETOWN\$500.53

$S B L D A=S B L U R * .3476$

$C B F L A=C B F L K \$ 500.53$

$c$
$C$
$c$

CHECK tO SEE IF PRIMAHY PLANT PARAMETERS ARE WITHIN SPECIFIED RANGES

002800

0032810

002820

002830

002900

002910

002920

002930

002940

002950

$0 \cap 2960$

$0 \cap 2970$

$0 \pi 2980$

$0 \cap 4080$

004100

004120

$0 \pi 4150$

$0 \pi 4160$

004170

004180

00190

$0 \cap 4200$

004210

IF (POWA.LT.3000 .OR.PUWA.VT.3800.) GO TO 150

IF (PCYOA.LT.5.OES.OR. PCVOA.GT.6.0E5) GO TU 150

IF (LETDWA.LT.3.2E4.OR,LETGWA. BT.4.2E4) GO TO 150

IF (SBLDA.LT.250.OOR.SQLDA.GT:1000) 60 TO 150

IF (CBFLA.GT.7500.) GO TO 150

c GO TO 190

c CALCULATE PRIMARY COULANT ADJUSTMENT FACTURS

C

150 AFPTES $=1.0$

RHAL2 $=$ (LETDWA $0.99+0 . \cup 1 * S O L D A) / P C V O A$

$K C S R B C=(L E T O W A * 0.5+0.5 *(S \forall L O A+C B F L A * 0.9)) / P C V U A$

KCFP $2=(L E T U W A * 0.98+0 . \cup 2 *(9 B L D A+C B F L A \otimes U .9)) / P C V O A$

004310

KK2 $=161.76$ POWA $/$ PCVOA

DO $180 \mathrm{~J}=1$, ITUT

IF (PCONC (J) .EQ.0.0) GU TO 180

iv $\angle=N U C_{L}(J) / 10000$

004360

$D L=U I S(J) * 3000$.

IF (NZ.E().53.OR.N7.ER.35) DO TU 160

$0 \cap 4370$

IF INZ.ER.37.UR,NZ.EQ.55) DO TO 170 


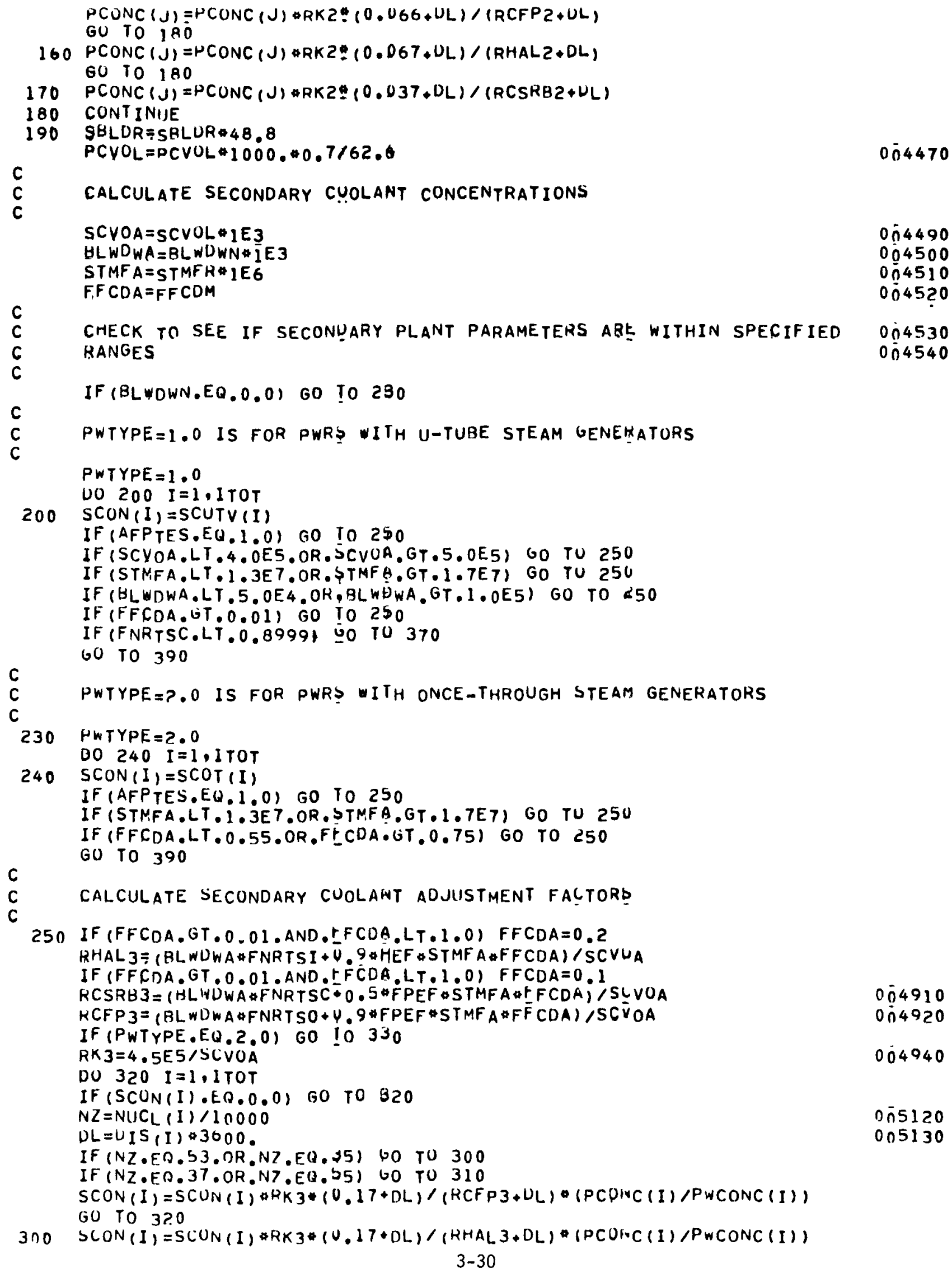


$310 \quad$ SCON TO 350 S

320 CONTINIJE

GO TO 390

330 RK3 $=1.0 \% E 5 / S C V O A$

DO $360 \quad I=1, I T O T$

IF (SCON (I) EEQ.0.0) GO TO $\$ 60$

$N Z=N U C L(I) / 10000$

005260

$O L=D I S(I) * 3600$.

IF (NZ,ER.53,OR,NZ,EQ.35) G0 TO 340

005270

IF (NZ,EQ.55,OR,NZ,EQ.37) 60 TO 350

$\operatorname{SCON}(I)=S \operatorname{CON}(I) * R K 3 *(i 4.0 * O L) /(R C F P 3+D L) *(P C O N C(I) / P W C O N C(I))$ 60 TO 360

340

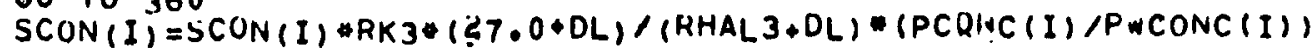

60 TO 360

$350 \operatorname{SCON}(I)=\operatorname{SCUN}(I) * R K 3 *(7.5+\mathrm{LL}) /(R C S R B 3+D L) *(P C Q(M C(I) / P W C O N C(I))$

360 CONTINUE

GO TO 390

370 RCSRB3 = (BLWDWA \#FNTSC $\$ 0.5$ \#PEF \#STMFA\#FFCDA) $/$ SLVOA

RK $3=4.5 E 5 / S C V O A$

DO $380 \quad I=1, I T O T$

IF (SCON $(I), E Q .0 .0)$ GO TO 380

$N Z=N U C_{L}(I) / 10000$

IF (NZ.NE.37.AND.NZ.NE,55) GO TO 380

$D L=D I S$ II) 3600 .

$\mathrm{HSC}=0.15$

$S C O N(I)=S C O N(I) * R K 3 *(H S C+N L) /(R C S R B 3+U L) *(P C Q N C$ (I) $/ P W C O N C$ (I)

380 CONT INIJE

$390 \quad B L W D W N=B L W D W N=1 E 3 / 500,53$

$S C V O L=S C V O L * 1000.162 .4$

STMFR $=S T M F R * 2000$.

DO $400 \quad I=I$, ITOT

IF (PCONC (I) EQ.0.0) GU TO 400

$P C O N C(I)=P C O N C(I) /(D I \$(I) \$ 1.6283 E(3)$

$\operatorname{SCON}(I)=\operatorname{SCUN}(I) /(D I S(I)=1.6283 E 13)$

$0 \overline{5} 390$

CONT INUE

c

C

COMPUTE REMUVAL CONSTANT POR CONDENSATE DEMINERALIZER

$0 \lcm{5410}$

005430

005460

$n \pi 5490$

005500

IF (FFCDM.GT .0.01. AND.FFCDO,LT,1.0) FFCDM $=0.1$

CIXRC $=10.9$ \&LWDWN 1)

CI XRCS $=10.5 * B L W D W N * R F !$ IVT /UFCSCM+0.5*STMFR*FPEL $* F F C D M) /(S C V O L * 7.40 * 0.5630$

160.1

IF (FFCOM.GT .0.01.AND.EFCUM.LT .1.0) FFCDM $=0.2$

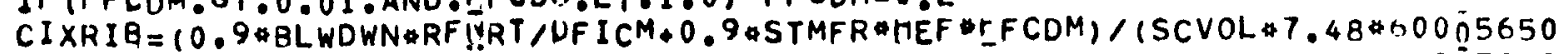

1.)

DO $410 \quad I=1, I$ TOT

$N Z=N U C_{L}(I) / 10000$

005530

005540

005560

$P R=C I X R C$

IF (NZ,EQ.37, OR,NZ,EQ.55) $P, R=C 1 \times K C S$

IF (NZ,EO.53,OR,NI,EQ.\$5) PRR=CIXHIB

$X Z H J=S C O N(I) \& P R * S C V O L \$ 0.02832$

$B(I)=X Z H J$

410 CONTINUE

CALCULATE RADIOISOTOPE INVENTURIES UN CONUENSA TE RESINS

CALL SOLVE

005790

DO $420 \quad I=1$, ITOT

$420 \operatorname{KINV}(I)=X \operatorname{TEMP}(I)$

CALL EFFTAB

STOH

0,5820 
C

9012 FORMAT $(16 X, 14 A 4, F 8,4)$

9013 FORMAT $(15 X, 4 A 4, A 2,8 X,+8,0,1 X, A 4, A 2, F 6,4)$

9014 FORMAT $(20 X, F 8.0,2(5 X, \bar{F}, 8,0))$

9015 FORMAT (27X,F 6.2,14X,FQ.2,18X,F 6.2)

9016 FORMAT "O",30X,"FRACTION FRACTION
1 FLLW RATE OF PCA
PISCHARGED

COLLECTIQH TIME

2MINATION FACTORS"/2OX "(GGL/DAY)"23X,"(DAYS) 3"I", 8X, "CS", 6X, "OTHERS"1)

9017 FORMAT $(2 X, 4$ A 4 , A2, 1PE9,2,18,4(OPF 8,4,2X),3(1PEY,2,1X))

9020 FORMAT $(16 X, 14 A 4, F 8.4)$

9021 FORMAT $(79 X$, II)

9022 FORMAT $(16 \times, 1444, F B .4)$

9026 FORMAT $(1 H 1)$

9027 FURMAT (16X, "PLANT CAPACITY FACTOR",T75,"0,800011)

9029 FORMAT (16X,"MMASS OF WÁTER IN STEAM GENERATORS (THOUSAND LBS)",T73.0n6900 ]F8.41

9030 FURMAT II6X, "FISSION PKODULT CARRY-OVER FRACTIUN",T75,F6.4/16X. 1 "HALOGEN CARRY-OVER FHACT1ON",T75,F6.4)

9034 FORMAT $(2 X, " B L O W D O W N "$ IOX, IPE $9,2,14 X, 0$ HF $5,3,2 X, 2(F 8,3,2 X)$, $13(1 P E 9.2,1 X))$

9035 FORMAT (2X. "UNTREATED PLOWOWN", IPE9.2.11X," $1.000 \quad 0.000$ $10.000 \quad 1.00 E+00 \quad 1.00 E+00 \quad 1.00 E+0011$

9037 FURMAT (72X,F 8.2$)$

9038 FORMAT (2X,"REGENERANT OLS ",1PE9.2,14X,OPF?.3,2X,2(F8,3,2X), $13(1$ PE9.2, $2 x)$ )

9039 FURMAT (3I $6, E 21.14)$

9040 FORMAT $(16, E 21.14)$

9041 FORMAT (I6X,"PRIMARY TU SECONDARY LEAK RATE (LOS/DAY)",T73, 1 " 75.0000 ")

9045 FUKMAT (/,"0 LIQUID WASTE INPUTS")

9046 FORMAT (/,"O GASEOUS WASTE INPUTS")

9048 FURMAT "O", I5X, "THERE IS NOT AN ON_SITE LAUNDKY")

9051 FORMAT (16X,"BLOWDOWN RATE (THOUSAND LBS/HH)", \$5X,F 8.4)

9052 FORMAT (16X,"THERE IS LONTINUOUS STRIPPING OF EULL LETDOWN FLOW")

9053 FORMAT (16X, "THERE IS NOT CONTINUUS STRIRPING OF FULL LETUWN FLON" 1)

9055 FURMAT $(36 \times, F 8.4,35 \times$, I I)

9056 FURMAT $(15 X, 4 A 4, A 2,8 X, F 8,0)$

9064 FORMAT (I6X,"STEAM LEAT̄ TO TURUINE BLOG (LBS/HK)", I9X,F10,4)

9065 FORMAT $(16 \times, 444,6 X, F 3.0)$

9066 FURMAT (16X,4A4,4X, "PAKTICULATE RELEASE FRACTIUN",6X,F 10,4$)$

9067 F,ORMAT $(16 X, 5 A 4,10 X, F 3,0,6 X, F 3,0)$

9068 FORMAT (16X,5A4,"IODINE RELEASE FRACTION",11X, $10,4 / 36 X, "$ PARTICULAT 1E RELEASE FRACTION",6Xं,F10.41

9069 FORMAT $(16 x, 5 A 4,10 X, F 3,0,6 x, F 3,0,14 X, F B, 2)$

9070 FORMAT (16X,5A4,"RATE (GFM)",25X,F10.4/16X,לA4,"IODINE RELEASE FRACT 1 ION", I IX,F10,4/36X, "PARTICULATE RELEASE FHACT!ON",6X,F 10.4)

9071 FURMAT $(16 x, 5 A 4,10 X, F 3,0,6 \bar{X}, F 3,0,19 X, F 3,0)$

9072 FORMAT ( $16 X$, "FREQUENCY OF CNTMT RLDG HIGH VOL PURGE $1: 1 M E S / Y R) ", 007330$ (T74,F 7.4)

9073 FOKMAT (16X,"THERE IS NOT A CNTMT BLDG LUW VUL HUHUE")

9075 FORMAT (16X, "THERE IS LONTINUOUS LOW VOL PURGE OF VOL. CONIROL TK"IOÖ7360 END

-DECK EFFTAB

SUBROUTINE EFFTAB

DIMENSION ISOTP $(3,1001$

UIMENS ION HEACTR $(7)$, NAME (3), CWCUNC $(800), D N C O N L(800)$, CMCONC $(800)$
007350

06510

006620

$0 \cap 6630$

0 i6640

006660

$0 \cap 6670$

$0 \cap 6910$

006920

$0 \cap 6930$

006960

007000 007010

0 กี 7020

007060 $0 \cap 7070$ Oก 70 RO On7090 007100 Uก7120 007140 007150 007370 007380 $0 \cap 7300$ 
DIMENS ION TURADR $(800)$, OWCUN2 $(800)$, EOCUNC $(800)$, IOTHER $(100)$ COMMON,FLUXN/REGENT,O!S $(\triangle D O)$, ILITE, IACT, ITOT

COMMON $/ O U T$ TNUCL ( $A O O$ O)

CUMMON , COOL/REACTR, POWI, SULDR , BLWDWN, F PEF, HEF, EUFLR, DF IED, DF CSED,

1 DFED, DFIUW, OF CSDW, DF UW,EDA, DWA , CWA, DF CM, UF I CM, DF CSCM,

2 DFCW, DF ICW, DFCSCW, BD I,FR, EDFD, DWFD, CWFD, CMFD, IS, TE, TU, TC, TCM,

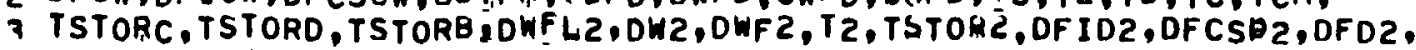

4 PFLAUN,DWFLR

COMMON /APCOOL/RGWFR, DLIRG O DF CSRG, DFRG, TRG, TSTURR, RGFD

COMMON/BUTES/RFNRT

COMMON/CONC/PCONC $(800), 5 C Q N(800), R I N V(800)$

007630

COMMON/DET/LAUNDRY (25L, WLAUND (25)

$c$
$C$
$c$
$C$

H3COPW IS THE PWR TRIIIUM PRIMARY COOLANT CONLENTRATION IN

UCI/GM

007800

$H 3 P R P W=0.4$ \#OW

$H 3 C O P W=1.0$

DO $30 \mathrm{~J}=1, \mathrm{ITOT}$

$\operatorname{CWCONC}(J)=0.0$

EDCONC $(J)=0.0$

UWCONC $(J)=0.0$

DWCONZ $(J)=0.0$

$\operatorname{CMCONC}(J)=0.0$

$N Z=N U C_{L}(J) / 10000$

IF (NZ.EQ.36.OR.NZ,EQ.24) to TO 30

CWCONC $(J)=P \operatorname{CONC}(J) * C W A$

$\operatorname{EDCONC}(J)=P L O N C(J) * E D A$

UWCONC $(J)=P C O N C(J) \nleftarrow D W A$

UNCONZ $(J)=P C O N C(J) \otimes D W द$

$\operatorname{CMCONC}(J)=\operatorname{SCON}(J)$

UFCVCS $=50$.

IF (NZ.EO.1)UFCVCS $=1.0$

IF INZ EEQ.35.OR,N7.EQ.S3, NFCVCS $=100$.

IF (NZ.EN.37.OR.N7.EQ.55) UFCVCS $=2$.

CWCONC $(J)=C_{W C O N C}(J) / D T C V C E$

C CONTINUE

CALCULATE RADIOACTIVIIY AETER COLLECTION AT A CONSTANT RATE

CALL COLLECT (TC\$B6400,,CWCONC,ITOT)

CALL COLLECT (TE $\$ 6400$, ,EOCONC, ITOT)

CALL COLLECT (TD $\$ 86400$, , DWLONC',ITOT)

CALL COLLECT (T2 \$B6400,,OWCON2,ITOT)

CALL COLLECT (TCM $\$ 8640 Y$., (MCONC,ITOT)

IF (REGENT.LE.0.0) GO TO 50

CALL STORAG (TRG $\$ 86400$, ,RINV, ITOT)

50 DO $100 \quad I=1$, ITOT

$N Z=N U C_{L}(I) / 10000$

TURBDR (I) $=1991 . * 5 . * S C \varphi N(I)$

IF (NZ•EO.1) GO TO 100

IF (NZ.ER.35.OR.NZ.EQ.53) bO TO 60

C

IF (NZ.ER.37.OR.NZ.EQ.55) פO TO 70

C

CHEMICAL THEATMENT FON OTHER CATIONS

CWCONC (I) $=$ CWCUNC (I) /UF CW

EUCONC (I) $=E U C O N C$ (I) $/ D F E D$

UWCONC (I) $=$ UWCUNC (I) $/ O^{-} D W$

DWCONG (I) $=0 W C O N 2$ (I) $/$ OFD2

C

CMCONC $(I)=\operatorname{CMCONC}(I) *(\vec{l}, 0-D D T F R \otimes(1.0-C M F D / U F C M)$,

008210

$0 \cap 8220$

008230

$0 \cap 8240$

$0 \cap 8250$

0 ก 8260

008270

008290

$0 \cap 8290$

$0 \cap 83 n 0$

$0 \cap 8310$

$0 \cap 8320$

$0 \AA 8330$

0 กิ8340

C

TU TREAT PWK TURRINE DUILUING FLOOR URAINS TMROUGH DIRTY WASTE

0038350 


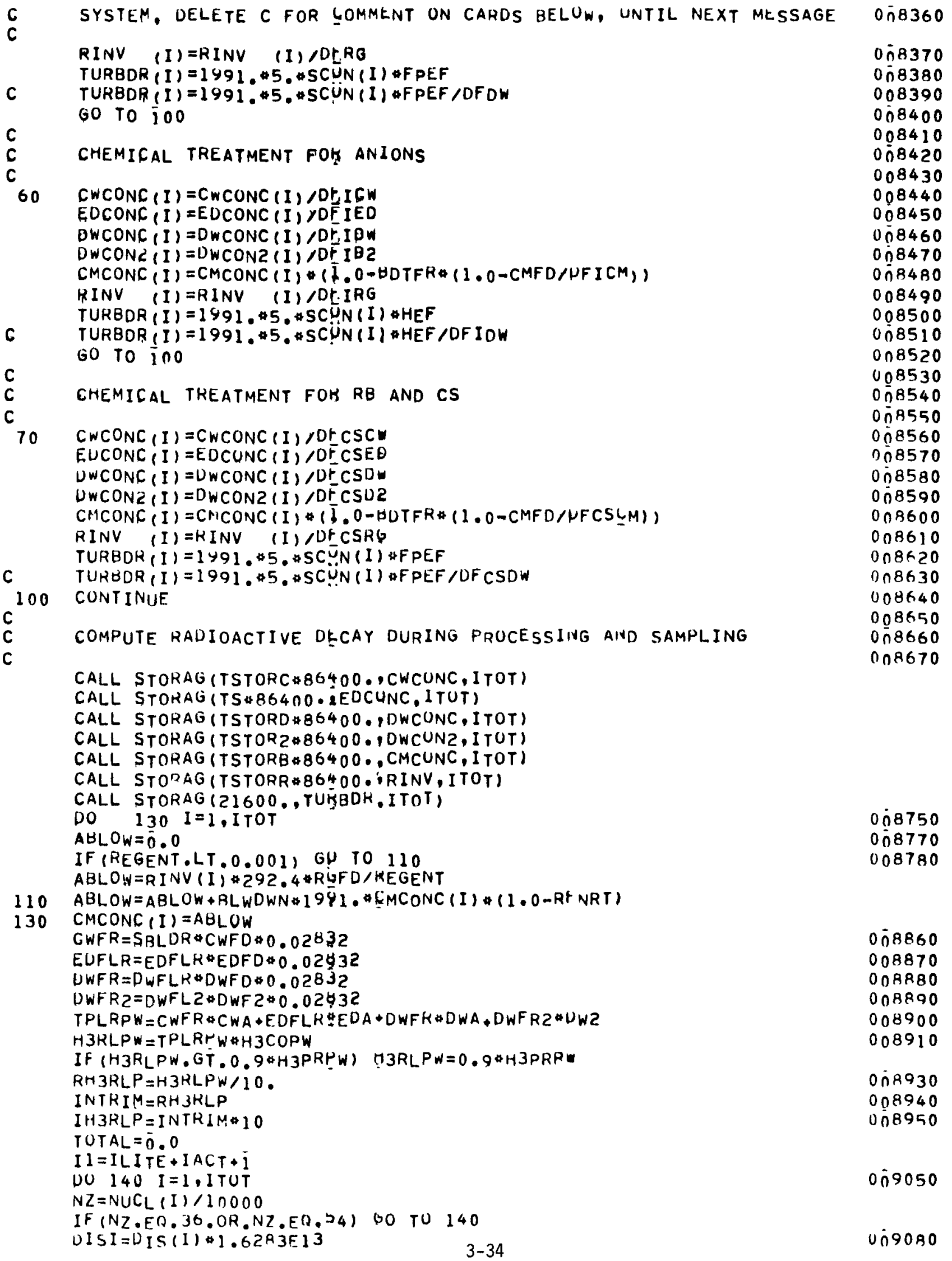




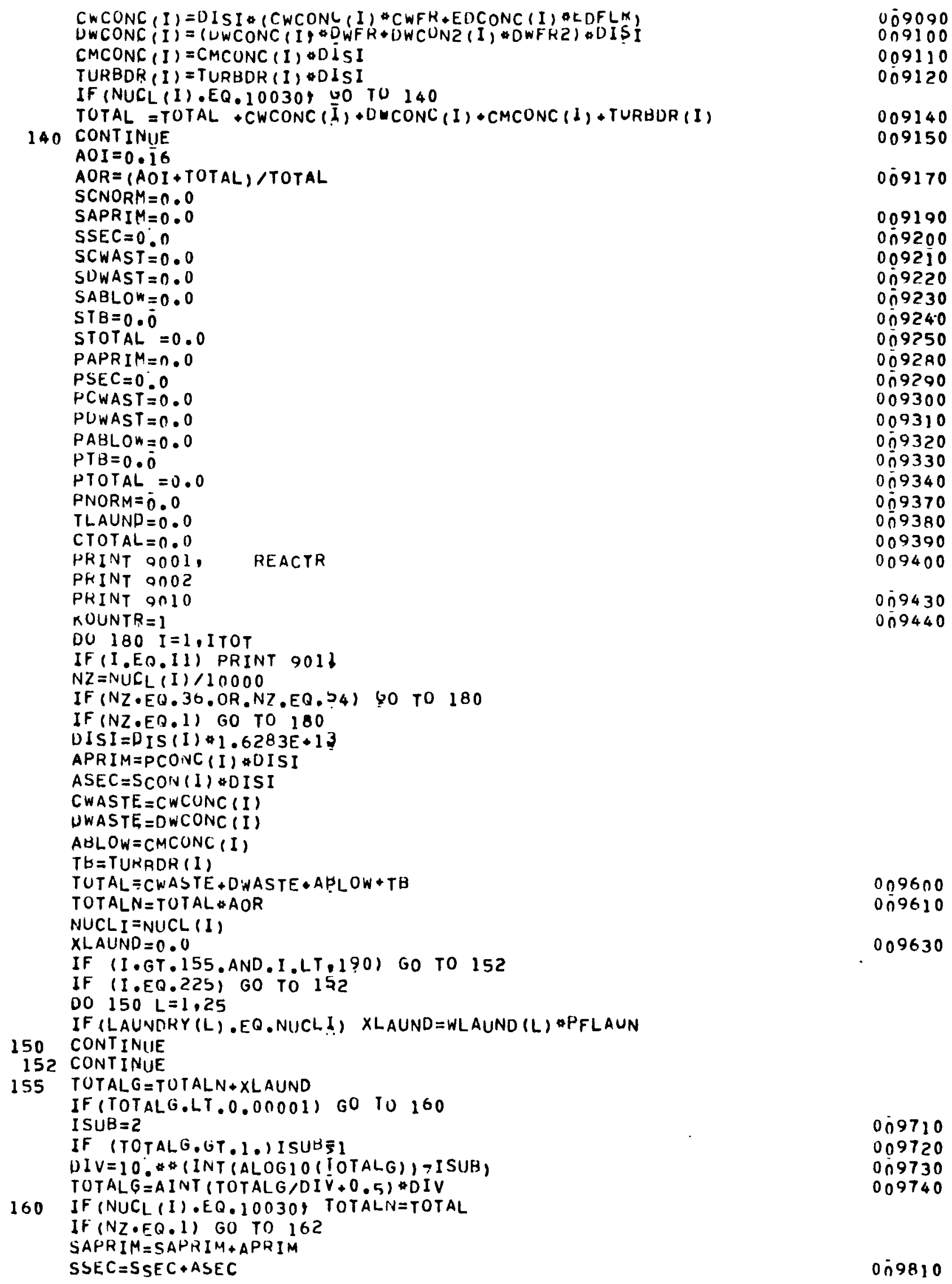


SABLOW = SABLUW+ABLOW $S C W A S T=S C W A S T+C W A S T E$ SDWAST $=S D W A S T+D W A S T E$ $S T B=S T B+T B$ STOTAL = STOTAL + TOTAL SCNORM = SCNORM + TOTALN $T L A U N P=T L A U N D+X L A U N D$ CTOTAL $=$ CTOTAL + TOTALG

162 IF (TOTALG.LT.0.00001) G0 TO 180

168 IF (MOP (KOUNTR,50).NE.P) GO TO 170 PRINT 9000, REACTR PIRINT 9002

170 CALL NOAH(NUCL (I), NAME)

THALF $=8.0225 E-6 / 0 I S Y I$ I

PRINT 9003 , NAME, THALF , APRIM, ASEC, CWASTE, OWASTE, ABLOW,

ITB, TOTAL, TUTALN, XLAUNU, TOTALG

KOUNTR $=K O U N T R+1$

IF (NZ•EA.1) GO TO 180

PAPRIM $=P A H R I M+A P R I M$

PSEC $=P S E C+A S E C$

PCWAST $=$ PCWAST + CWASTE

POWAST = PUWAST + DWASTE

$P A B L O W=P A B L O W+A B L O W$

$P T H=P T B+T B$

PTOTAL =PTUTAL + TOTAL

PNORII=PNOHM+TOTALN

1 BO CONTINUE

PAPRIM = SAPRIM-PAPRIM

HSEC $=$ SSEC-PSEC

PCWAST $=$ SCWAST-PCWAST

PUWAST $=$ SUWAST -PDWAST

PABLOW = SAOLOW-PABLOW

$P T B=S T B-P T H$

PTOTAL = STUTAL-PTOTAL

PNORM = SCNUKM-PNORM

ISUBC $=$ ?

IF (CTOTAL.GT,1.) I SUBC $=1$

DIV $=10 . *$ (INT (ALOG IO (CTOTAL)) $\rightarrow$ ISUBC)

CTOTAL =AINT (CTOTAL/DIV+0.\$) *DIV

IF (PNQRM.LT.0.0000It GO TU 190

DIV $=\overline{1} 0 . *$ (INT (ALOGIV (PNQRM) )-2)

PNORMT = AINT (PNORM $/ O I V \div 0.5) \nleftarrow D I V$

GO TO 200

190 PNORMT $=$ PNORM

200 PRINT 9004,

1

PAPRIM,PSEC, PCWAST, POWAST, PABLDW, PTB, PTOTAL, PNORM,

PRINT 9005 , PNORMT

1 SAPRIM, SSEC, SCWAST, SOWAST, SARLD", STB, STOTAL, SCNORM, TLAUND, GTOTEQL

$0 \overline{00030}$

$0 \overline{10050}$

$0 \overline{10060}$

$0 \overline{10070}$

$0 \overline{00 R 0}$

$0 \overline{10000}$

$0 \overline{10100}$

070110

$0 \overline{10140}$

$0 \overline{10150}$

$0 \overline{0160}$

010170

010180

010190

$0 \overline{0} 020$

$0 \overline{0210}$

$0 \overline{10220}$

010250

$0 \overline{10260}$

010270

$0 \overline{10280}$

ט 10290

010310

०广0320

PHINT 9012, IH3RLP

$0 \overline{1} 0380$

$0 \overline{10390}$

$0 \overline{0400}$

PRINT 9013

RETURN

9000 FURMAT (IHI,20X,7A4," LIUUID EFFLUENTS (CONTINUED)")

9001 FURMAT (IHI,20X,7A4," LIQUID EFFLUENTS")

9002 FORMAT IIHO,55X, "ANNUAL RELEASES TO DISCHAKGE LANAL"/20X, "COOLANT CO 10500 IONCENTRATIUNS",57("-"l," ADJUSTED ?E HALF-LIFE PRIMARY SECONDARY 3UARY TURE BLDG TOTAL LWO TOTAL DETEKGEN! TOTAL "/" NIICLIDOT05iO 4"(DAYS) "Z("(MICRO $L I / M L) "), 1 X, 4$ ("(CURIES) "),"(CURIES) ", 010540 5" $\left(C_{I} / Y R\right) \quad(C I / Y R I$ I (CI/YR)")

$0 \overline{1} 0420$

$0 \overline{1} 0480$ $0 \div 0490$

FURMAT (IX,A2, I $3, A 1,2 X, 1$ PE $9,2,2(2 x, E 9,2,2 x), 0 P, 7(1 X, F 9,5,1 X), F 10,5)$

9004 FORMAT (1 $X$, "ALL OTHERS", ?X, IPE $9.2,4 X, E Y, 2, U P, 2 X, 6(1 X, F 9,5,1 X), 3 X$,

1 1"0.00ก0", $1 \times, F 10.51$ 
9005 FOHMAT(" IUTAL"/," IEXCEPT TRITIUM) ",IRE9,E,4X,E9.2,00;2X,

$17(1 \times, F 9.5,1 \times), F 10.5)$

9010 FORMAT (" COKROSION ANU ACIIVATION PRODUCTS"I)

9011 FORMAT ("OFISSION PRODUCTS")

9012 FORMAT (1HO,1X,"TRITIUM RELEASE",12X,13," CURIES PER YEAR")

070740

$0 \overline{1} 0750$

9013 FORMATIIHO,IX, "NOTE, ,0OODO INDICATES THAT THE VALUE IS LESS THAN $11.0 E-5,11$

9014 FORMAT $(3 X, 10(2 x, A 2,13, A 1) / 3 X, 10(2 X, A 2,13, A 1))$ END

-DECK BLKDAT BLOCK DATA BLKDAT

PWCONC CONTAINS PRIMARY COOLANT CONCENTRATIONS FOR PWRS, SCUTV AND SCOT CONTAIN SECONDARY COOLANT CONCENTRATIONS FOK PLANTS WITH UGTUEE STEAM GENERATORS ANO FOR PLANTS WITH ONCE-THRUUGH STEAM GENERATORS, RESPECTIVELY.

COMMON/CONP/PWCONC $(800)$, SCUTV $(800)$, SCUT $(800)$

COMMON/DET/LAUNDRY (25), WLAUND (25)

BATA PWCONC/36*0,4.7E62,67*0,3,1E-3,4*0,1.6E -3,5*0,1,2E-3,3*0,3.0E $1-4,0,0,4,6 E-3,2 * 0,5,3 E-4,17 * 0,5,1 E-4,102 * 0,2,>E-3,64 * 0,2,2 E-3,68 * 0$ $2,1.6 E-2,1840,1,9 E-1,4 \$ 0,1,4 E-4,340,1,2 E-5,540,9,6 E-4,4,6 E-4,5,2 E-6$ $3,940,4,2 E-3,11 * 0,3,9 E 44,0 \cdot 0,2,8 E-4,15 * 0,6,4 E-3,4,7 E-3,16 * 0,7,5 E-3$, $415 * 0,9, \cap E-2,0,0,20 * 0,1.3 E-3,104 * 0,1,9 E-4,2,4 E-2,12 * 0,1,5 E-3,7,7 E-3$ $5,4,5 E-2,5 * 0,1,7 E-3,2 . i E-1 ; 4 * 0,1,4 E-1,5 * 0,3,4 E-1,2 * 0,7,1 E-3,2 * 0,2,6$ $6 E-1,8 * 0,8,7 E-4,3 * 0,9,4 E-3,13 * 0,1,3 E-2,2,5 E-2,5 * 0,1,5 E-4,12 * 0,2,8 E-$ $73,3 * 0,3,9 E-3,92 \$ 0 /$

DATA SCUTV/36*0,1.5E-9.67*0,1,3E-7,4*0,6,5E-8,5*0,4,9E-8,3*0,1.2E$18,0,0,1,9 E-7,2 * 0, ? .2 E 68,17 * 0,2,1 E-8,102 * 0,8,7 E-8,64 * 0,8,4 E-8,68 * U$, $27.5 E-8,18 * 0,5,3 E-7,4 * 0,5,7 E-9,3 * 0,4,9 E-10,5 * 4,2,8 E-8,3,2 E-9,2.1 E-1$ $30,9 * 0,1,2 E-7,11 * 0,1,6 E-8, n, 0,1,1 E-8,15 * 0,2,5 E-7,1,1 E-7,16 * 0,3,1 E-7$ $4,15 * 0,3,7 E-6,0,0,20 * 0,5,3 t-8,104 * 0,7,8 E-9,2,2 E-7,12 * 0,5,4 t-8,2,9 E-$ $58,1, B E-6,5 * 0,6,6 F-8,3,1 E-6,4 * 0,4,8 E-6,5 * 0,2,4 E-6,2 * 0,3,3 E-7,2 * 0,6$. $66 E-6,8 * 0,4,0 E-8,3 * 0,4,4 E-7,13 * 0,5,2 E-7,9,3 E-7,5 * 0,6,1 E-9,12 * 0,1,0 E$ $7-7,3 * 0,1,6 E-7,92 * 01$

DATA $S \mathrm{COT} / 36 * 0,1,0 E<7,67 * 0,6,9 \mathrm{E}-9,4 * 0,3,6 \mathrm{E}-9,5 * 0,2,7 \mathrm{E}-9,3 * 0,6,7 E-1$ $10,0,0,1,0 E-8,2 * 0,1,2 E+9,17 * 0,1,1 E-9,102 * 0,5,6 E-9,64 * 0,4,9 E-9,68 * 0$, $21,8 E-8,18 *, 6,0 E-7,440,3,1 E-10,3 * 0,2,7 E-11,5 * U, 2,1 E-9,9,7 E-10,1.2 E$ $3-11,940,9,3 E-9,11 * 0,8,7 E-10,0,0,6,2 E-10,15 * 0,1,4 E-8,1,0 E-8,16 * 0,1$. $47 E-8,15 * 0,2,0 E-7,0,0,40 * 0 ; 2,9 E-9,104 * 0,4.2 E-10,5,1 E-8,12 * 0,3,3 E-9$, $51,5 E-8,5,2 E-8,5 * 0,3,8 E-?, 2,4 E-7,4 * 0,1,6 E-7,5 * 0,3,8 E-7,2 * 0,3,0 E-8,2$ $6 * 0,3,0 E-7,8 * 0,3,6 E-9,3 * 0,3,9 E-8,13 * 0,2,9 E-8,5,6 E-8,5 * 0,3,3 E-10,12 *$ $70,6 \cdot 2 E-9,3 * 0,8,7 E-9,92 * 01$

C

C

C

LAUNDHY ARE THE RADIOISOTOPES IN THE DETEKGENI WASTES. WLAUNB ARE THE CORRESPONUING CONCENTRATIONS.

DATA LAUNURY $/ 150320,240510,250540,260550,260590,270580,270600,2806$ $130,380890,380900.390910,400950,410950,420990,441030,441060,471101$. $2511240,531310,551340,951360,551370.561400,581410,581440 /$

DATA WLAUNO $/ 1,8 E-4,4,7 E-3,3,8 E-3,7,2 E-3,2,2 E-3,7,9 E-3,1,4 E-2,1,7 E-$ $13,8,8 E-5,1,3 E-5,8,4 E-5,1,1 E-3,1,9 E-3,6,0 E-5,2,9 E-4,8,9 E-3,1,2 E-3,4$ $2,3 E-4,1,6 E-3,1,1 E-2,3,7 E-4,1,6 E-2,9,1 E-4,2,3 E-4,3,9 E-3 /$

ENO

$0 \lcm{1230}$

SULVE

SUBROUTINE SOLVE

COMMON/EQ) XTEMP $(800)$, XNEW $(10,800), B(800), N(800)$

$0 \longdiv { 1 2 4 0 }$

*DECK

COMMON/FLUXN/REGENT,D!S $(800)$, ILITE, IACT, I !OT

DO $10 I=I$, ITOT

011250

$D(I)=-D I S(I)$

$10 \times \operatorname{TTEMP}(I)=0.0$

UELT = REGE'NT $\$ 86400$.

CALL DECAY (1, UELT, ITO!)

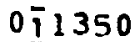

071360

011370

$0 \longdiv { 1 3 9 0 }$ 
CALL. TERM (UELT, $1, I T O T)$

CALL EQUIL (1, ITOT)

$0 \overline{1410}$

DO $30 I=1$, ITOT

011420

$X \operatorname{TEMP}(I)=X N E W(1, I)$

RETURA

END

-DECK TERM

SUBROUTINE TERM(T,M,IIOT)

$C$
6
$C$
$C$
$C$
$C$
$C$
$C$
$C$
$C$
$C$
$C$

TERM ADDS ONE TERM TO EACU ELEMENT OF THE SOLUTION VECTOR

CSUM(N) IS THE CURRENT APPROXIMATION TO XNEW(H,J)

CIMO(N), IS THE VECTOR CONTAINING THE LAST TERM ADDED TO EACH

ELEMEAT OF CSUM(J)

CIMN(N) IS THE VECTOR CONTAINING 1/TON TIMES IHE NEW TERM TO BE

ADDED TO CSUM (J)

CIMN (N) IS GENERATED EROM CIMO(J) BY A RECURSION RELATION: CIMN $(J)=$ SUM OVE $L$ OF $(A P(J i L) * C I M O(L))$

$A P(I, N)$ IS THE REDUCEบ TRANSI İION MATËIX FOR IHE LONG-LIVED

NUCLIDES

LOGICALLONG

DIMENSION AP $(2500), \operatorname{CIMA}(800), \operatorname{CIMO}(800), \operatorname{CIMN}(800), \operatorname{CSUM}(800)$

OIMENSION QUB $(50)$, LOCP $(2500)$, NONP $(800)$

COMMON/SERIES/ XP $(800 \AA$, XPAR $(800)$, LONG $(800)$

$0 \overline{1430}$

011440

$0 \overline{1450}$

$0 \overline{1460}$

COMMON / CUNST / MMN, ERR, MZERU

COMMON/EQ/XTEMP $(800)$, XNEW $(10,800) ; B(800), N(800)$

COMMON/MATRIX/A $(2500), L O C(2500)$, NONO $(800), K D(000)$

$0 \longdiv { 1 4 8 0 }$

$0 \overline{1} 1490$

$0 \longdiv { 1 5 0 0 }$

$0 \frac{1}{1510}$

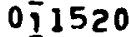

$0 \overline{1530}$

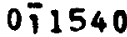

$0 \overline{1} 1550$

011560

o 11570

$0 \overline{1} 1580$

$0 \overline{11590}$

$0 \overline{11600}$

LEVEL $2, A, L O C, N O N O, K O$

$0 \longdiv { 1 6 9 0 }$

COMMON TERMU $/ D D(100 \%, U X P(100)$, OUEUE $(50)$, NUU (50), NOUEUE (50), NQ $(800)$ NUL $=0$

NN $=0$

$c$

FIRST CONSTHUCT REDUCED TKANSITION MATRIX FOR LUNG-LIVED ISOTOPES

DO $220 \mathrm{~L}=1$, ITOT

IF(.NOT.LUNG(L)) GO TU 210

NUM $=N O N \cap(L)$

IF (M.GST.MMN,OR,M.EQ,MZERO) NUMA=KD(L)

CIMH $(L)=B(L)$

IF (NUM.LE.NUL) GO TO $2 ! 0$

$N S=N N+\overline{1}$

$N=N U L$

$N L=N U M-N U L$

DO $200 \mathrm{NI}=1, \mathrm{NL}$

$N=N+1$

$N=L O C(N)$

$D J=-D(J)$

$0 \overline{1730}$

0 0 0540

$0 \longdiv { 1 7 5 0 }$

$0 \leq 1760$

$0 \div 1770$

$0 \overline{1} 1780$

$0 \overline{1790}$

011800

011810

011820

$0 \overline{1} 1830$

011840

$0 T 1850$

011860

011870

071880

011890

$0 \div 1900$

$0 \overline{1} 1910$

C

THIS IS A TEST TO SEE IF ONE OF THE ASSYMPTQIIC SOLUTIONS

011920

C

IF (.NOT.LONG (J)) GO TU 10

$N N=N N+1$

$A P(N N)=A(N)$

$\operatorname{LOCP}\left(N_{N}\right)=J$

GO TO 200

$C$
$C$
$C$
$C$

GOING BACK UP THE CHA! NN TU FIND A PARENT WHICE IS NOT IN

EQUILIBRIUM

NSAVE $=\overline{0}$

QUE $=A(N) / D \mathrm{~J}$

$D R B=1 \cdot \overline{0}$

$\operatorname{CIMB}(L)=\operatorname{CIMB}(L)+D U E * B(J)$

NUQ $(L)=0$ 


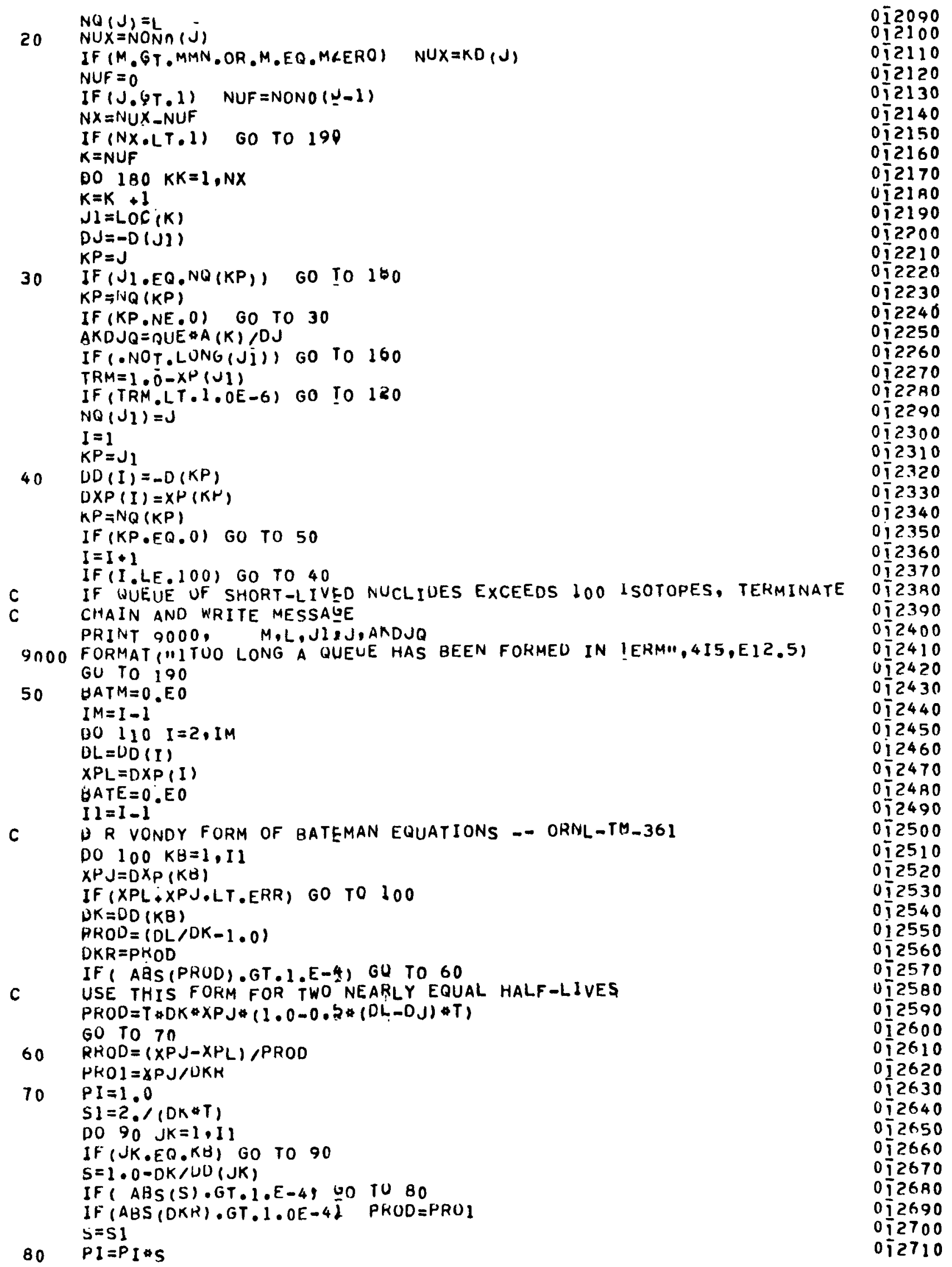


IF (ABS (PI).GT.1.E25) GO TO 100

$0 \lcm{2720}$

CONTINUE

$0 \longdiv { 2 7 3 0 }$

BATE $=$ BATE +PROD $/ P I$

$0 \longdiv { 2 7 4 0 }$

100 CONTINUE

C

IF SUUMATIUN IS NEGATIVE, SET EQUAL TO ZEHO AND PRINT MESSAGE

$0 \overline{12750}$

IF (BATE.LT.0.EO)PRINTYOOI,L,IM,BATE,BATM

$0 \div 2760$

$0 \lcm{2770}$

9001 FORMAT "IBAIE IS NEGATIVE IN TEKM. IHERE ARE MORE THAN TWO SHORT-LOİZTBO 1 IVED NUCLIDES IN A CHAIN VITH NEARLY EQUAL DIAGONAL ELEMENTS $/ 1012790$ 2" L,IM,BATE,BATM = ", ZIS, IPZE (2,5)

IF (BATE,LT.O.EO)BATE= Q.EO

BATM $=$ BATM+BATE

110 CONTINUE

DRA = AKDJQ UU* (TRM-BATM ) TTRM

GO TO 130

120 DRA $=A K D J Q * A M A X I(D R B, 0,0) * D J$

$0 \overline{12800}$

012810

012820

$0 \overline{2830}$

012840

IF (NS.GT.NN) GO TO 150

DO 140 LJ=NS, NN

IF (LOCP (LJ).NE.JI) GH.TO 140

012850

प 2860

012870

$0 \longdiv { 2 8 8 0 }$

$A P(L J)=A P(L J)+D R A$

$0 \longdiv { 2 8 9 0 }$

$0 \longdiv { 1 2 9 0 0 }$

GO TO 180

140 CONTINIIE

$150 \quad N N=N N+1$

$A P(N N)=D R A$

$L O C P\left(N_{N}\right)=J 1$

GU TO $\bar{\jmath} 80$

160 IF (AKDJQ.LE.1.0E-06) GO TO I80

$0 \longdiv { 2 9 1 0 }$

$0 \overline{12920}$

$0 \overline{129.30}$

$0 \longdiv { 2 9 4 0 }$

$0 \overline{12950}$

$0 \lcm{2960}$

012970

IF (NSAVE.GE.50) GO TO 1 B.

170 NSAVE =NSAVE +1

(VUUEUE (NSAVE) $=J 1$

QUEUE (NSAVE) $=A K D J Q$

NQU (NSAVE) $=U$

QUB (NSAVE) $=\dot{U} R B-1 \cdot /(D \cup \$ T)$

$0 \longdiv { 2 9 8 0 }$

$0 \longdiv { 2 9 9 0 }$

$0 \uparrow 3000$

$0 \longdiv { 3 0 1 0 }$

$0 \% 3020$

$0 \overline{1} 3030$

CONT INUE

190 IF (NSAVE.LE.O) GO TO ZOO

$0 \longdiv { 1 3 0 4 0 }$

$0 \longdiv { 3 0 5 0 }$

$J=N Q U E U E$ (NSAVE)

$0 \longdiv { 3 0 6 0 }$

QUE = QUEUE (NSAVE)

$0 \overline{1} 3070$

$N Q(J)=N D U$ (NSAVE)

ט 3080

URB =QUB (NSAVE)

$0 \longdiv { 3 0 9 0 }$

$C I M B(L)=C I M B(L)+Q U E \otimes B(J) * A M A X I(1) R B, 0.0)$

$0 \div 3100$

NSAVE

$0 \frac{1}{13110}$

GO TO 20

$0 \div 3120$

$\begin{array}{ll}200 & \text { CONTINUE } \\ 210 & \text { NUL }=\text { NONO (L) }\end{array}$

013130

013140

$\operatorname{NONP}(L)=N N$

$0 \longdiv { 3 1 5 0 }$

220 CUNTINUE

$0 \overline{3160}$

C FIND NORM OF MATRIX AYOD EBTIMATE ERROR AS DESCRIGED IN LAPIDUS

$0 \longdiv { 1 3 1 7 0 }$

C AND LUUS, OPTIMAL CONIROL OF ENGINEERING PROCÉSSES BLAISDELL 1967

C FIND THE MINIMUM OF TIIE MAXIMUM ROW SUM AND T⿱艹̈E MAXIMUM COLUMN SUMO ASUM $=\overline{0} .0$

$A S \cup M J=0.0$

13180

$N U L=1$

DO $250 \quad I=1, I T O T$

IF (.NOT.LONG (I) GO TU. 250

$D I=-D(I) \oplus T$

$A J=D I$

NUM $=$ NONP (I)

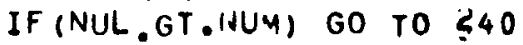

DO $230 \mathrm{~N}=N U L, N U M$

013200

013210

$0 \longdiv { 1 3 2 2 0 }$

013230

013240

$0 \overline{1} 3250$

013260

013270

$0 \longdiv { 1 3 2 R 0 }$

$0 \overline{1} 3290$

$230 \quad A J=A J+A P(N)$

$0 \overline{3300}$

$240 \quad A I=0 I+D I$

IF (AI.GT.ASUM, ASUM $=A I$

$0 \overline{13310}$

If (AJ.GT.ASUMJ) $A S U M J=A J$

013320

$0 \overline{3330}$ 
USE ASUM TU DECIDE HOW MAINY TERMS ARE REQUIREW AND ESTIMATE ERROK 013360 NLARGE $=3.5 * A S U M+5$.

ERR I =EXP (ASUM) (ASUM *2.71828/XLARGE) *NLARGE/SORT16.2832*XLARGE) 013390 IF (ERR I.GT.1.E-3) PRINT 9002, ERR1, ASUM INLARGE

9002 FORMAT ("OMAXIMUM ERROB GT 0.001, =11F10.6,", TKACE = "F10.4.

$0 \overline{3400}$

1 "NLARGE = "16)

C NEXT GENERATE MATRIX EXPONENTIAL SOLUTION

$0 \div 3410$

$0 \longdiv { 3 4 2 0 }$

DO $260 \quad I=1$, ITOT

$\operatorname{CSUM}(I)=X \operatorname{TEMP}(I)$

$\operatorname{CIMN}(I)=X \operatorname{TEMP}(I)$

260 CONTINUE

EKR3 $=0.001$ \#ERR

DO $310^{\circ} \mathrm{NT}=1$, NLARGE

DO $270 I=1,1$ TOT

$\operatorname{CIMO}(I)=\operatorname{CIMN}(I)$

270 CONTINUE

$T O N=T / N T$

NUL $=1$

DO $300 \quad I=1$, I TOT

IF (.NOT.LUNG II) GO TU 300

$0 \longdiv { 3 4 3 0 }$

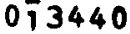

$0 \overline{1} 3450$

$0 \frac{1}{3460}$

$0 \longdiv { 1 3 4 7 0 }$

$0 \longdiv { 3 4 8 0 }$

$0 \overline{1} 3490$

$0 \overline{3500}$

$0 \div 3510$

$0 \overline{1} 3520$

$0 \overline{13530}$

$0 \longdiv { 1 3 5 4 0 }$

$0 \overline{1} 3550$

$0 \overline{1} 3560$

NUM $=$ NONP (I)

CI MNI $=\tilde{0} .0$

IF (NT.EQ.1) CIMNI $=$ CIMP(I)

$0 \longdiv { 3 5 7 0 }$

IF (NUL.GT. INUM) GO TO Z9O

$0 \overline{1} 3580$

$0 \longdiv { 3 5 9 0 }$

UO $280 \mathrm{~N}=\mathrm{NUL}$, NUM

$J=L O C P(N)$

$280 \quad \operatorname{CIMNI}=\operatorname{CIMNI}+A P(N) * \operatorname{CIMU}(J)$

$290 \quad \operatorname{CIMNI}=C I M N I+D(I) * C I M O(I)$

CIMNI $=$ TON $\#$ CIMNI

IF (ABS (CIMNI) -LT .ERR3) CIMNI $=0$.EO

$\operatorname{CIMN}(I)=\operatorname{CIMIVI}$

$\operatorname{CSUM}(I)=\operatorname{CSUM}(I)+\operatorname{CIMNI}$

300 NUL $=N O N P(I)+1$

310 CONTINUE

DO $320 \quad I=1, I$ TOT

IF (CSUM(I) .LT.ERR) $\quad \operatorname{C\supseteq UM}(I)=0.0$

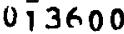

$0 \overline{3610}$

$0 \longdiv { 3 6 2 0 }$

$0 \longdiv { 3 6 3 0 }$

$0 \overline{3} 3640$

$0 \div 3650$

$0 \longdiv { 1 3 6 6 0 }$

013670

$0 \longdiv { 1 3 6 8 0 }$

$0 \longdiv { 3 6 9 0 }$

$0 \frac{1}{3700}$

0 3710

$0 \overline{1} 3720$

IF (LONG (I)) XNEW(M,I)

320 CONTINUE

KETURN

013730

$0) 3740$

$0 \longdiv { 3 7 5 0 }$

END

-DEGK DECAY

SUBROUTINE UECAY $(M, T, \downarrow T O T)$

C GECAY TREATS SHORT-LIVED ISOTOPES AT BEGINNINQ OF CHAINS USING

$0 \overline{13760}$

0,3770

$0 \overline{3780}$

$0 \overline{3790}$

BATEMAN EQUATIONS

LOGICALLONG

COMMON/SERIES/ XP $(800), X P Q R(800)$, LONG $(800)$

$0 \div 3800$

$0 \overline{13810}$

CUMMON/CONST/MMN,ERR, MZEHU

$0 \uparrow 3860$

COMMON /EQ $/ X T E M P(800), X N E M(10,800), R(800), R(800)$

CUMMON/MATRIX/A $(2500), L O C(2500), N O N O(800), K D(800)$

$0 \overline{1} 3900$

$0 \overline{0} 0560$

COMMON,TERMU /DD $(100), 0 \times P(100)$; OUEUE $(50)$, NUU $(50)$, NQUEUE $(50), N Q(800) 013910$

$A X N=-A L O G(0.001)$

UU $10 \quad I=1,1$ TOT

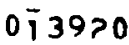

$\operatorname{XPAR}(I)=0.0$

0 j 3930

LONG I I $=. F A L S E$.

$0 \frac{1}{3940}$

$X P I=0.0$

$U T=D(1) * T$

IF (DT.LT. -50.$)$ GO TO 10

IF (ABS (DT) .LE.AXN) LUNG I I) =.TRUE.

$0 \div 3950$

$0 \overline{1} 3960$

XPI =EXP(OT)

013970

$0 \longdiv { 1 3 9 8 0 }$

$0 \longdiv { 3 9 9 0 }$ 


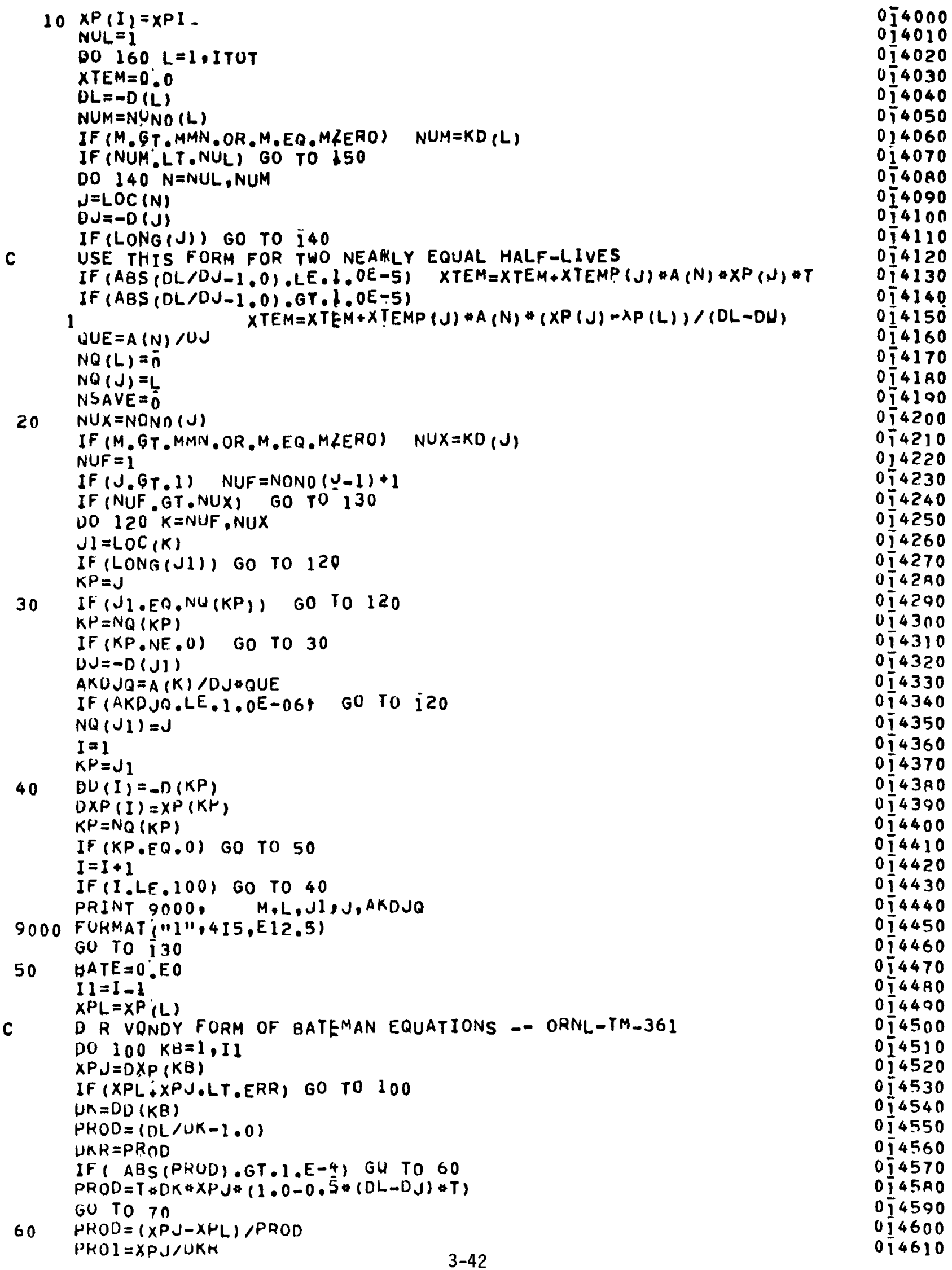




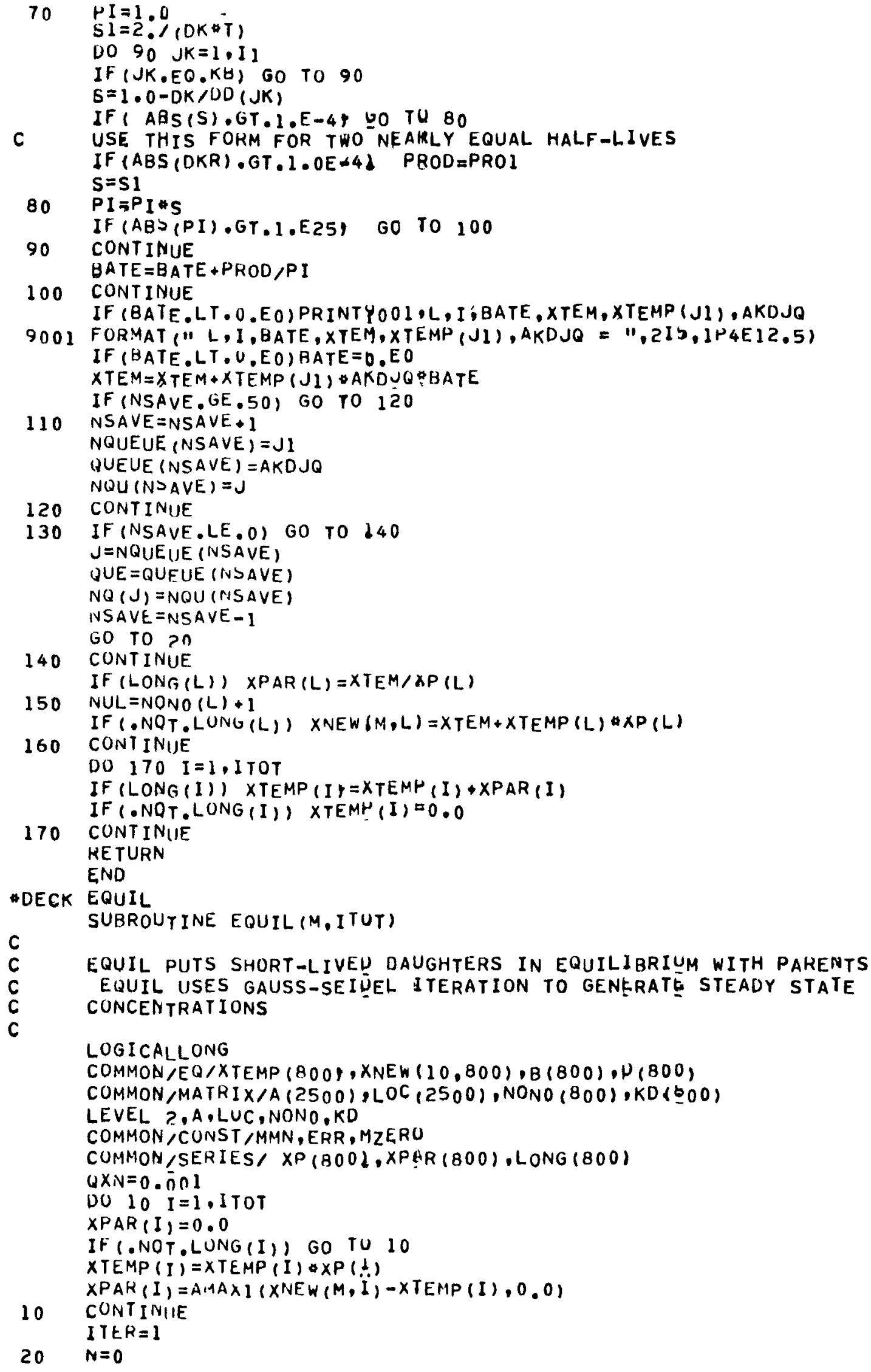




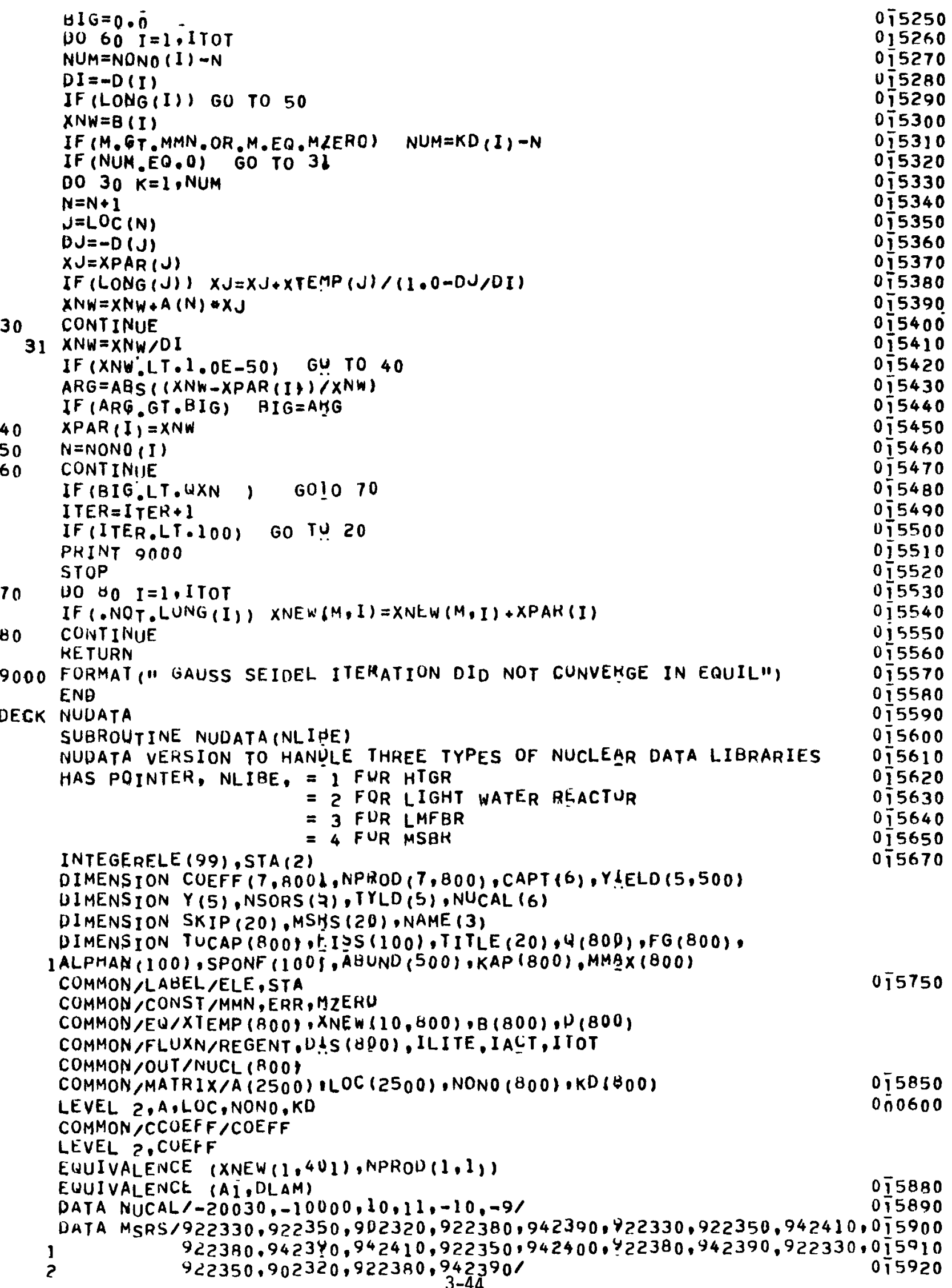




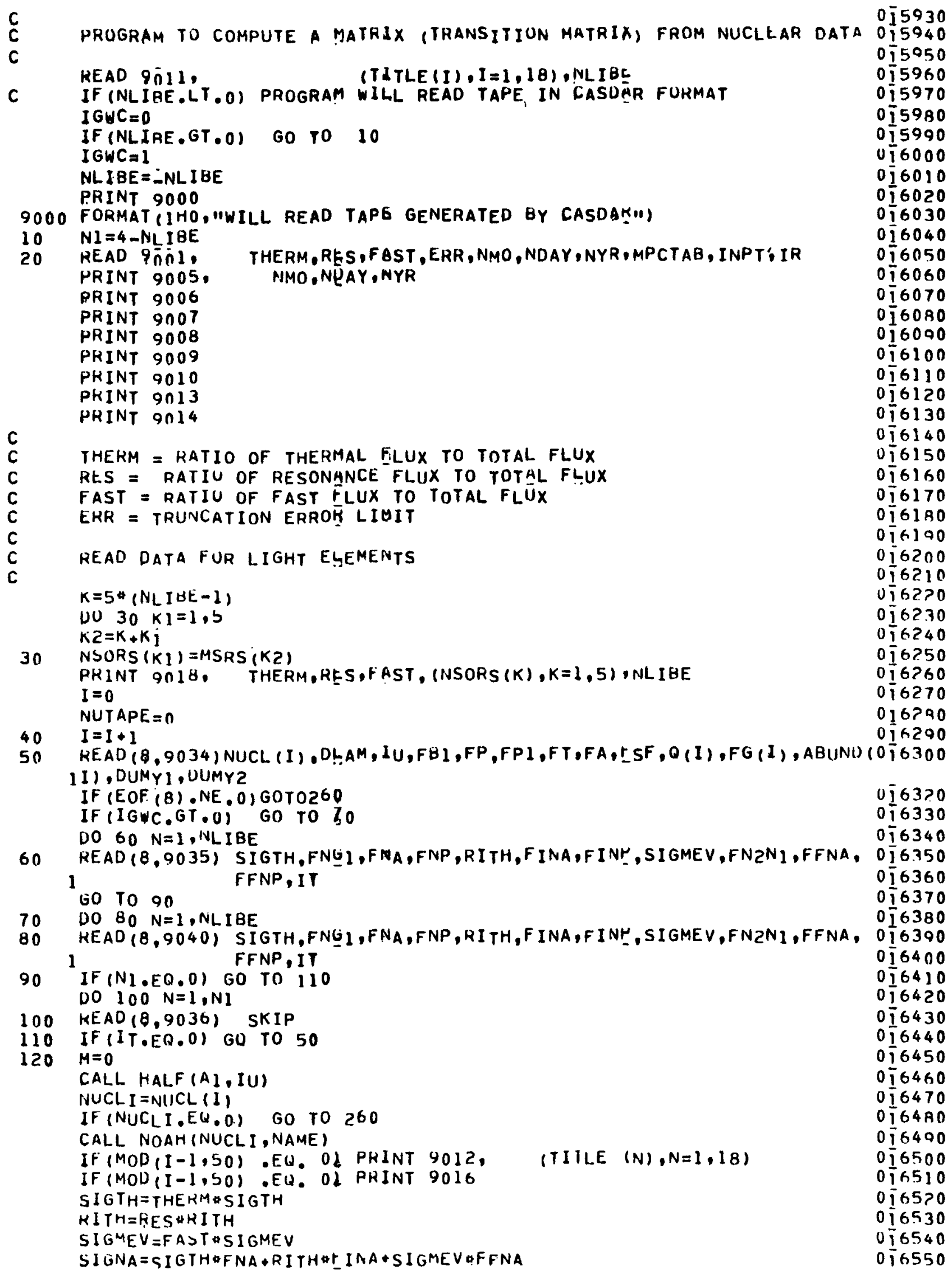


$S I G N P=S I G I H * F N P+R I T H * I I A P+S I G M E V * F F N P$

$0 \overline{16560}$

$F N G=1.0-F N A-F N P$

IF (FNG,LT, I, OE -4)FNG =U.

F. ING $=1: 0-F$ INA-F INP

IF (FING.LT.1.OE-4)FING=0.

FN2N=1:0-FFNA-FFNP

IF (FNZN,LT I, OE -4)FN2N $=0$.

$S I G N G=S I G T H \# F N G * R I T H \# I_{I N G}$

SI GNZN=SIGMEV \$FNZN
130 PRINT 9033, NAME.
1
FNG
140 IF (A).LE.ERR) GO TO 180
ABETA $=\overline{1}, 0$

DLAM,FBI,FE,FPI,FT,EA, SIGNG,
SIGNA, SIGNP, Y I I, FG I I, ABUND I

C
C
C
C

$0 \overline{16570}$

$0 \overline{6580}$

$0 \overline{16590}$

$0 \longdiv { 6 6 0 0 }$

$0 \overline{166 \overline{10}}$

$0 \overline{16620}$

$0 \overline{16630}$

$0 \longdiv { 1 6 6 4 0 }$

$0 \longdiv { 1 6 6 5 0 }$

$0 \longdiv { 6 6 6 0 }$

$0 \overline{\$} 6670$

$0 \longdiv { 6 6 8 0 }$

016690

\section{TEST POSITRON EMISSION}

IF (FP :LT. ERR) GO TO 150

$M=M+1$

$\operatorname{CUEFF}(M, I)=F P * A I$

NPROD $(M, I)=N U C L I-10000$

$A B E T A=\triangle B E T A-F P$

C

C

TEST POSITRUN EMISSION TO EXCITED STATE OF PRUDUCT NUCLIDE

IF (FPI LT. ERR) GO TU 150

$M=M+1$

$\operatorname{COEFF}(M, I)=F P I * \operatorname{COEFF}(M-1, d)$

$N P R O D(M, I)=N P R O D(M-1, I)+1$

C

$\operatorname{COEFF}(M-1, I)=\operatorname{COEFF}(M-1, I)-\operatorname{COEFF}(M, I)$

C TEST ISOMERIC TRANSITLON

C

150 IF (FT LLT.ERR) GO TO 160

$M=M+1$

$\operatorname{COEFF}(M, I)=F T * A I$

$\operatorname{NPROD}(M, I)=N U C L I$

ABE TA $=A B E T A-F T$

c

c TEST ALPHA EMISSION

160 IF (FA:LT.ERR) GO YO 170

$M=M+1$

$\operatorname{COEFF}(M, I)=F A \otimes A I$

NPROD $(M, I)=N U C L I-20040$

$M=M+1$

$\operatorname{COEFF}(M, I)=\operatorname{COEFF}(M-1, h)$

$N P R O D(M, I)=20040$

c

ABETA $=$ ARETA-FA

C

TEST NEGATRON EMISSION

170 IF (ABETA.LT.1.E-4) GO TO 180

$M=M+1$

$\operatorname{CUEFF}(M, I)=A B E T A * A I$

NPROD $(M, I)=N U C L I+10000$

c

TEST AEgATRUN EMISSION TO EXCITED STATE OF PRUDUCT NUCLIDE

IF (FBI LLT. ERR)GO TÚ 180

$M=M+1$

$0 \overline{6700}$

$0 \overline{16710}$

$0 \uparrow 6720$

$0 \overline{6730}$

$0 \overline{16740}$

$0 \longdiv { 1 6 7 5 0 }$

$0 \overline{16760}$

016770

016780

$0 \frac{1}{16} 6900$

$0 \overline{6800}$

$0 \uparrow 6810$

$0 \overline{1} 6820$

$0 \overline{16830}$

$0 \overline{16840}$

$0 \overline{16850}$

016960

$0 \overline{16870}$

$0 \longdiv { 6 8 8 0 }$

$0 \div 6890$

$0 \longdiv { 6 9 0 0 }$

$0 \overline{6910}$

$0 \overline{169 ? 0}$

$0 \overline{16930}$

$0 \overline{16940}$

$0 \overline{16950}$

016960

$0 \overline{16970}$

$0 \overline{1} 6980$

076990

0 7000

017010

017020

$0 \overline{7} 7030$

$0 \overline{1} 7040$

017050

0] 7060

077070

$0 \% 7080$

077090

$0 \div 7100$

0 ำ110

017120

$0 \overline{17130}$

017140

077150

$0) 7160$

$0 \div 7170$ 


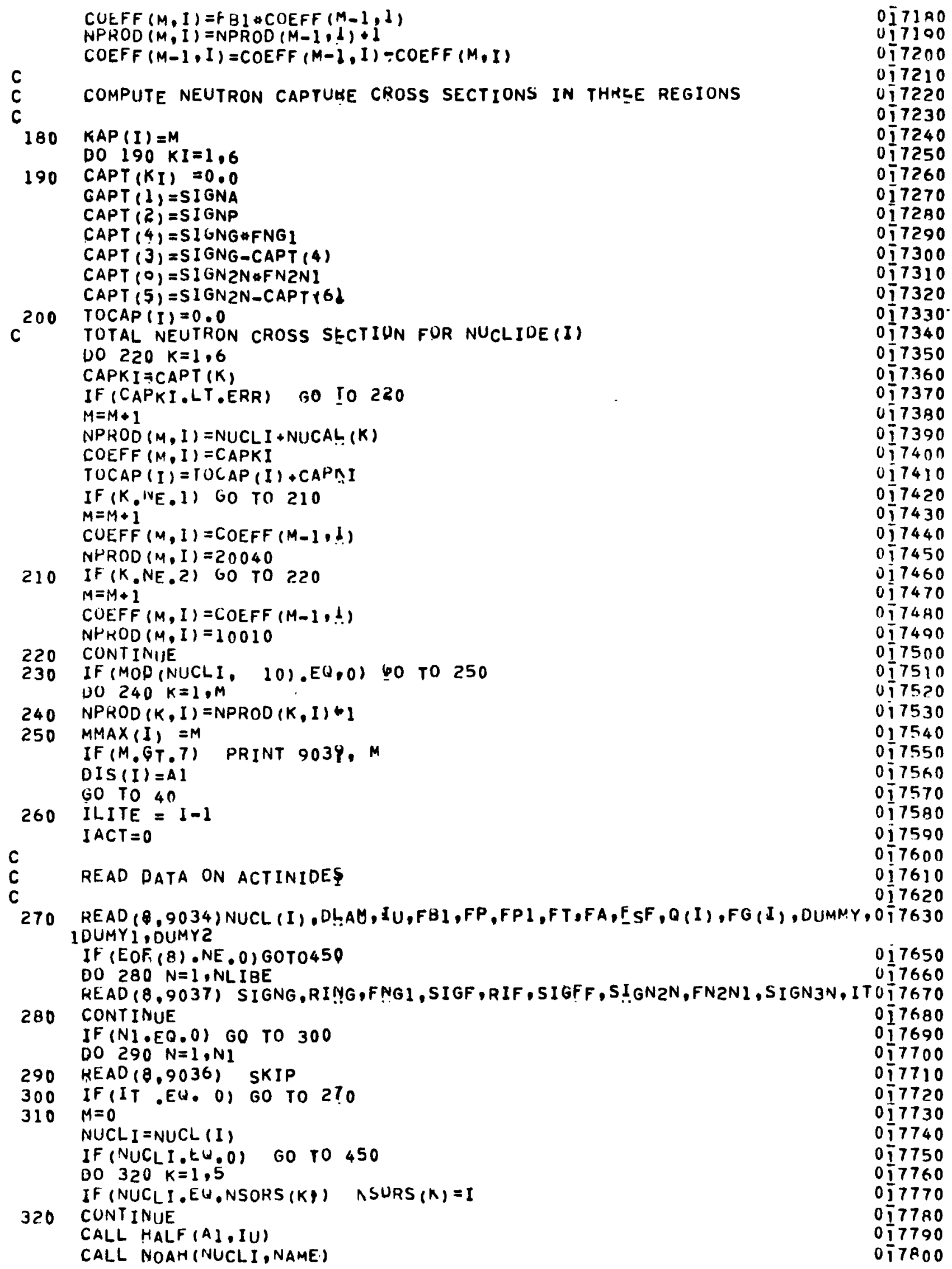




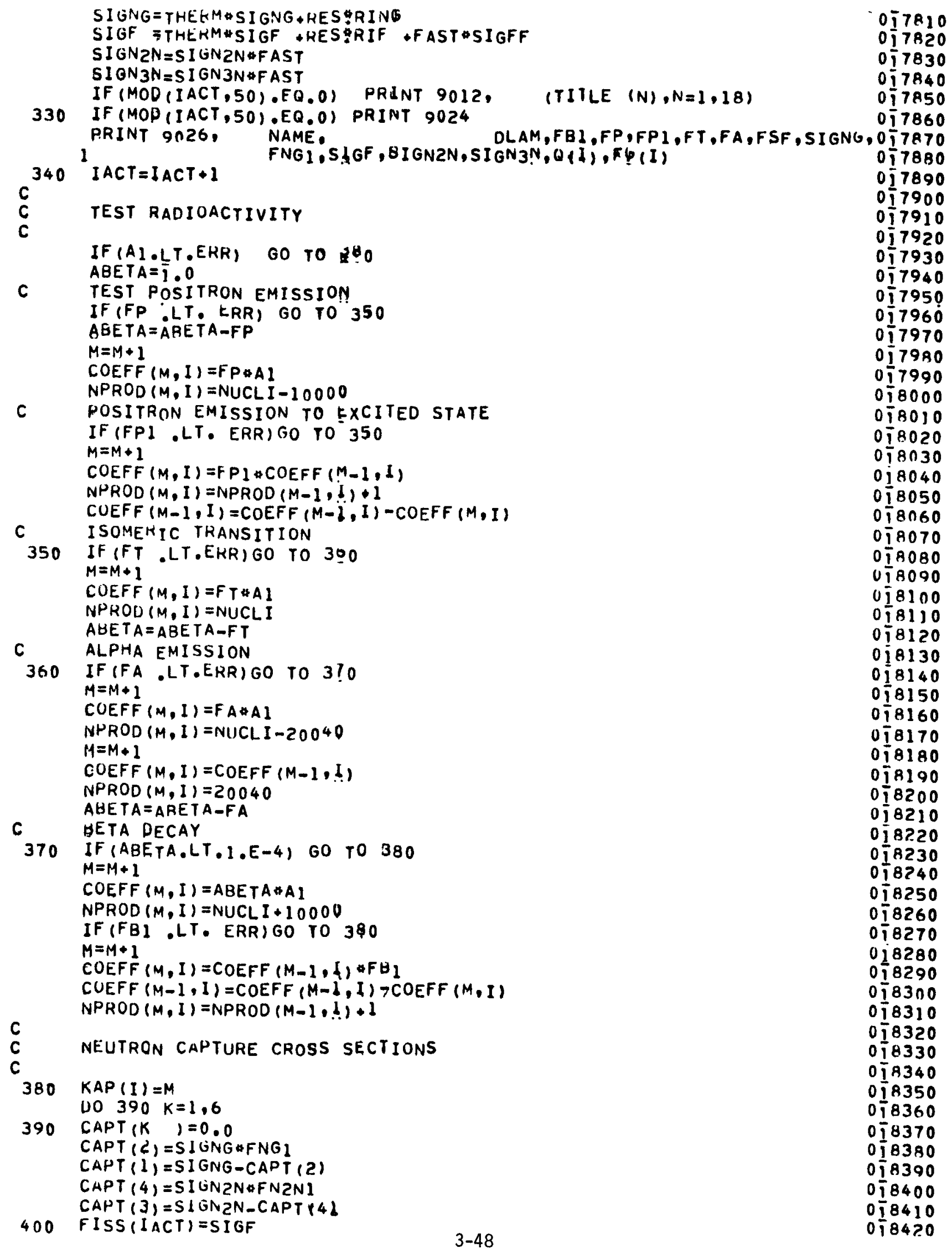




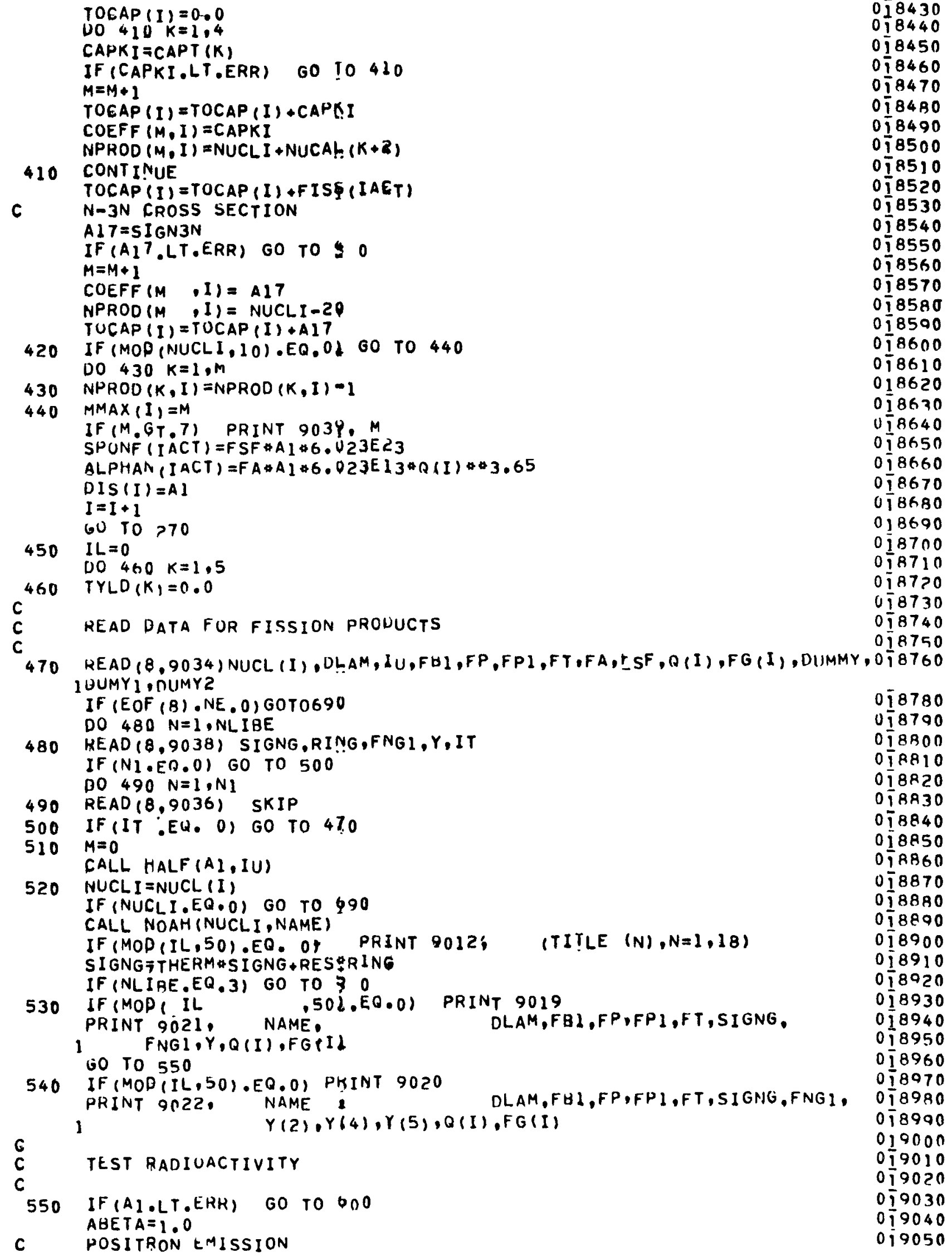

$0 \overline{8780}$

$0 \frac{1}{8700}$

$0 \overline{18800}$

$0 \frac{1}{1} 8810$

018820

018830

078840

018850

0,8860

$0 \div 8870$

$0 \longdiv { 8 8 8 0 }$

018890

$0 \overline{18900}$

018910

018920

018930

018940

$0 \lcm{8950}$

018960

$0 \uparrow 8970$

$0 \overline{18980}$

$0 \overline{8990}$

0,9000

$0 \% 9010$

$0 \overline{19020}$

$0 \lcm{9030}$

$0 \overline{9040}$

$0 \lcm{9050}$ 


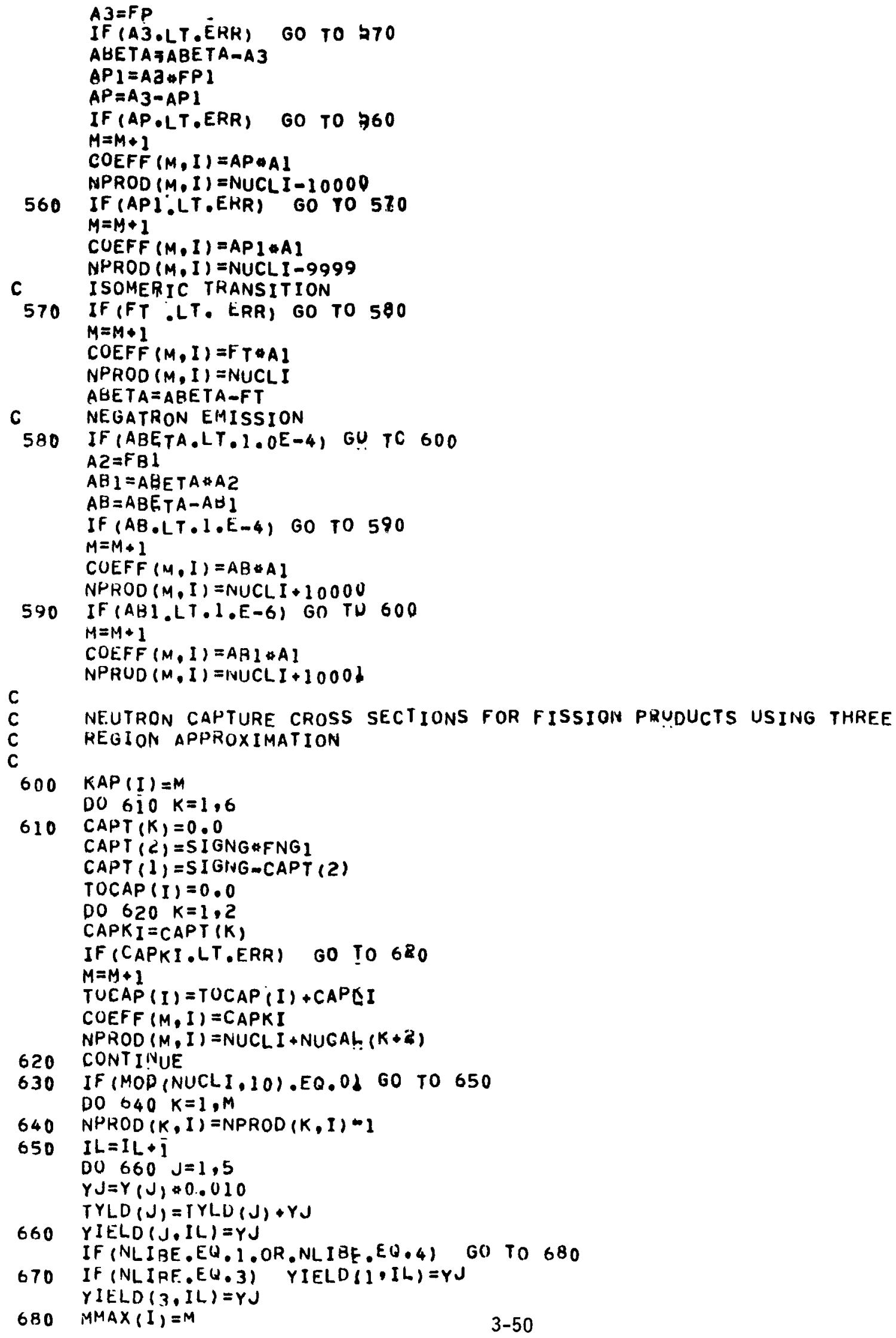

$0 \overline{9} 9240$

$0 \longdiv { 9 2 9 0 }$

0 19300

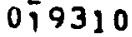

$0 \longdiv { 9 3 2 0 }$

019330

$0 \overline{9} 9340$

$0 \overline{19350}$

$0 \longdiv { 9 3 4 0 }$

$0 \div 9370$

0 93 म

$0 \lcm{19390}$

019400

$0 \longdiv { 9 4 1 0 }$

019420

$0 \longdiv { 9 4 3 0 }$

$0 \overline{19440}$

$0 \frac{19450}{9}$

$0 \longdiv { 9 4 6 0 }$

$0 \lcm{9470}$

$0 \overline{1} 9480$

$0 \lcm{9490}$

079500

$0 \longdiv { 9 5 1 0 }$

$0 \longdiv { 1 9 5 2 0 }$

$0 \longdiv { 9 5 3 0 }$

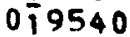

$0 \longdiv { 9 5 5 0 }$

$0 \overline{19560}$

$0 \div 9570$

019590

$0 \overline{9590}$

$0 \div 9600$

019610

$0 \overline{1} 9620$

019630

019640

$0 \longdiv { 9 6 5 0 }$

0 19660

$0 \longdiv { 9 6 7 0 }$ 


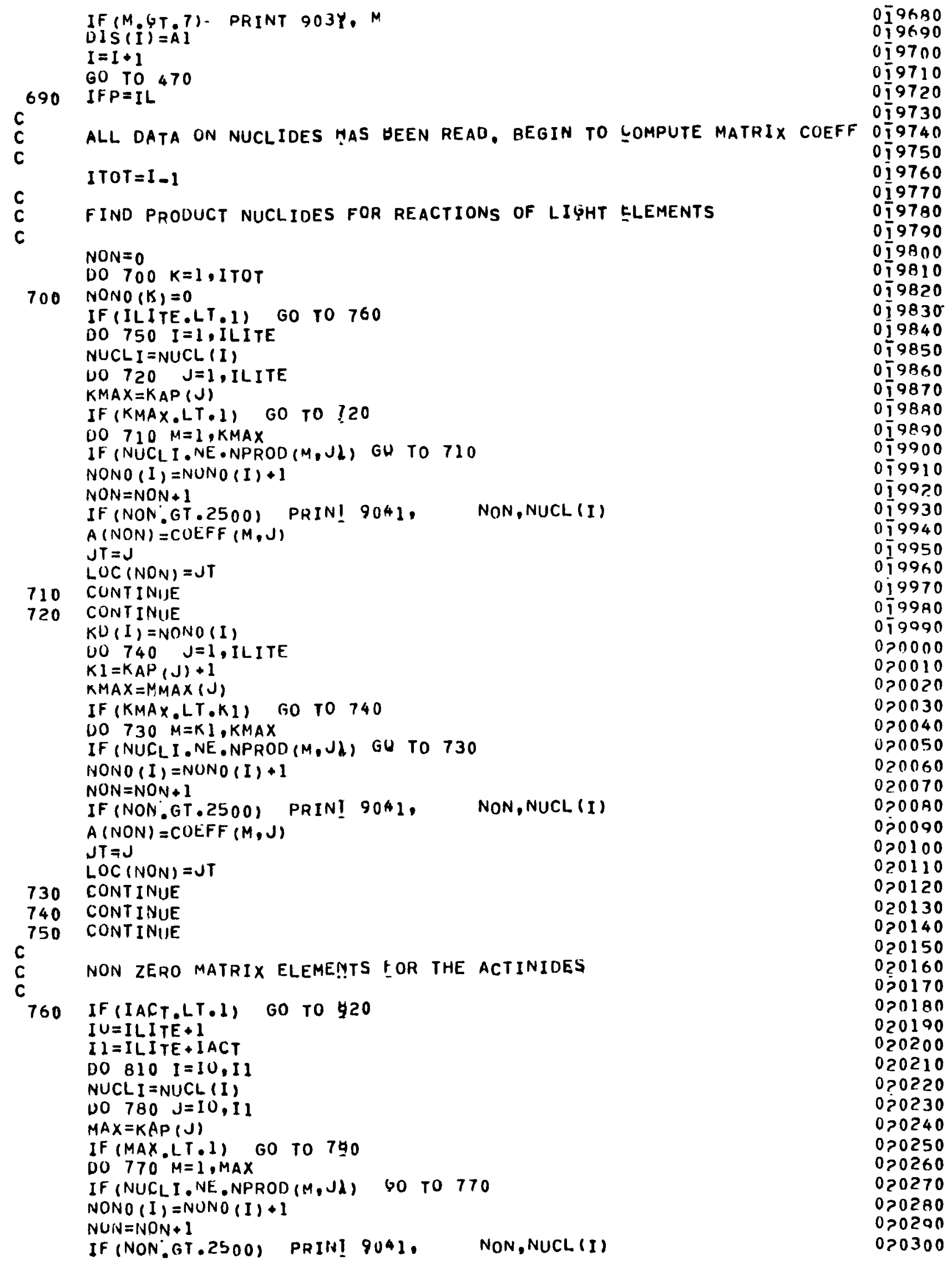




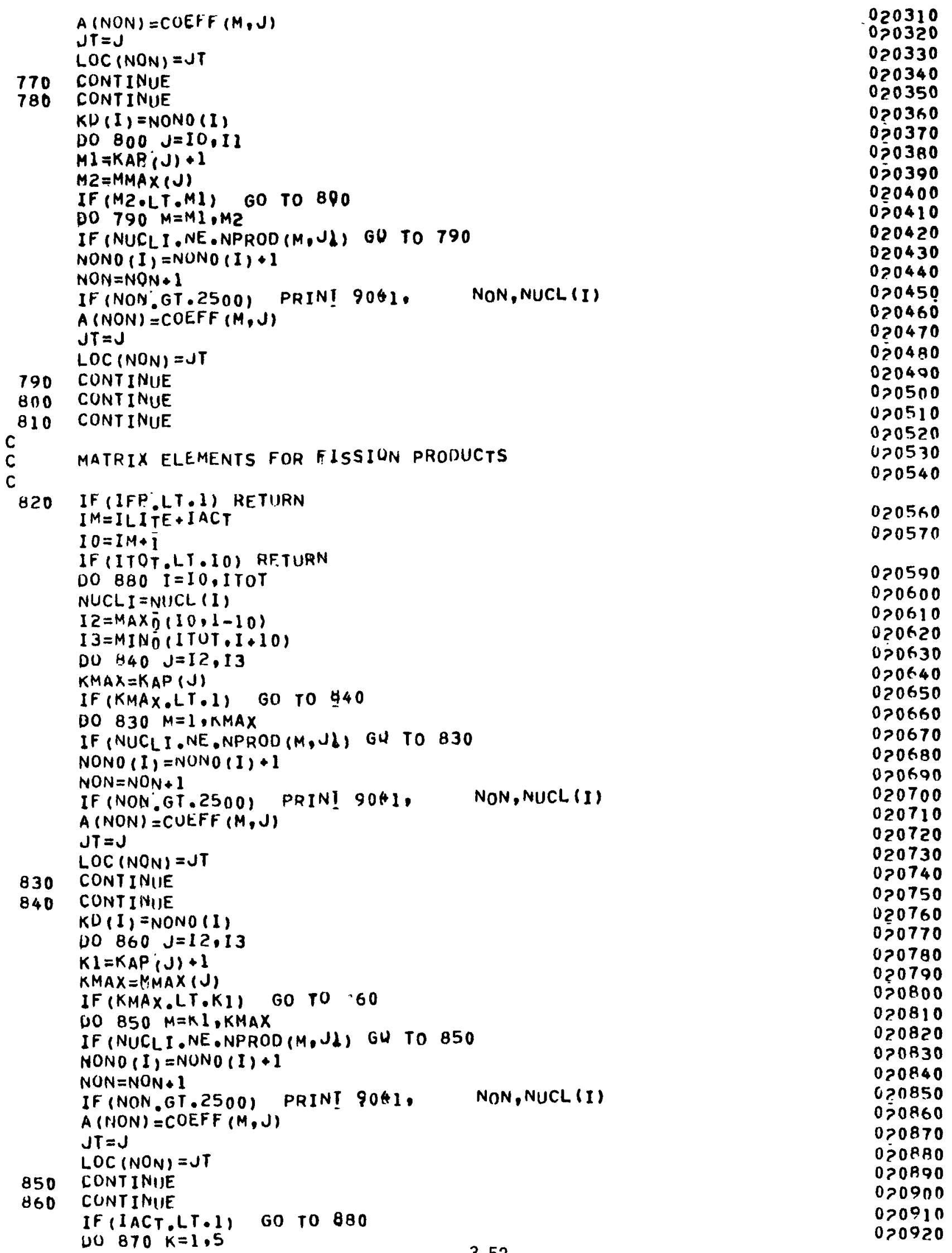


$I L=I-I M$

IF (YIELD (K,IL),LT.ERR) GU TO 870

$0>0930$

$N O N=N O N+1$

IF (NON.GT.2500) PRINI 9041, NON,NUCL (I)

020940

$0>0950$

NONO (I) $=$ NONO (I) +1

020960

$K K=N S O R S(K)$

$L O C(N 9 N)=K K$

$K F=K K-I L I T E$

$A(N O N)=Y I E L D(K, I L) * F I \$ S\left(K F_{1}\right)$

870 CONTINUE

880 CONTINUE

IF (IFP.LE.O) GO TO 900

IF (NLIRE.NE.3) GO TO $\$ 90$

PKINT 9027 , TYLDY21, TYLD(4), TYLD(5)

GO TO 900

C

PRINT $9030, \quad$ (TYLD(I), $1=1,5$ )

ALL MATRIX ELEMENTS AKE NUW COMPUTED

BEGIN TRANSIENT SOLUTION

020970

$0 ? 0980$

$0 ? 0990$

$0 ? 1000$

0 ว 1010

021020

021030

021040

$0>1050$

$0 ? 1060$

021070

$0>1080$

$0>1090$

021100

$0>1110$

021120

$0>1130$

TEMPORARILY WRITE OUT MATKIX ELEMENTS

021140

$0>1150$

$0>1160$

021170

PRINT ONZS

$N=0$

DO $910 \quad I=1,1 \mathrm{TOT}$

INUM $=$ NONO (I)

IF (NUM.LE.0) GO TO 910

$N I=N+N(I M$

$N=N+1$

PRINT 9.28, I,UIS II), TOCAP $(I),\left(A(K), L U C(K), K=N, N_{1}\right)$

0211 म0

$0>1190$

$0>1200$

$0>1210$

$0>1220$

$0>1>30$

$0 ? 1240$

$0>1250$

$0>1260$

$N=N I$

$0>1270$

021290

RE TURN

920 STOP

C

C

c

9001 FORMAT (4F10.5,6I2)

021290

$0 ? 1300$

021310

021320

9005 FORMAT $11 \mathrm{Hl}, 43 \mathrm{X}$, "NUCLEAR TKANSMUTATION DATA HEVISED ", I $2, " / ", 12, " 0>1370$

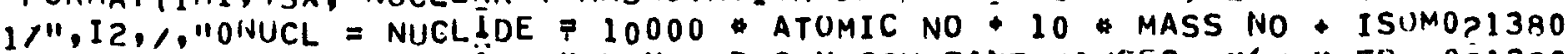
2ERIC STATE (0 OR 1)",IOX, "DLAM = DECAY COINSTAPT $(1 / S E C), " \% /$ "FB, 0?1390 3FP, FA, FT = FRACTIONAL DECAY BY BETA, POSITRÜN IOR ELECTRON CAPTUOJ1400 4HE), ALPHA, INTERNAL TRANSITION. FB = I FP - FA - FT":1, FBI.021410 5 FPI. FNGI, FN2NI = FRACTION UF BETA, POSITRDI, N-GAMMA, N-2N TRANO? 1420 6SITIONS TO EXCITED STATE UF PRODUCT NUCLINE"," SIGTH, SIGNG, SIG0?1430 $7 F$, SIGNA, SIGNP = THERMAL CKOSS SECTIUNS (BARNS) FOR ABSORPTION, NOJ1440 B-GAMMA, FISSION, N-ALP.HA, N-PROTON.")

021450

9006 FORMAT" SIGNG = SIUTTH 11 - FNA -FNPI. SIGNA = SIGTH *FNA. 0 1460 $1 S I G N P=$ SIGTH * FNP. FNA; FNP = FRACTION THEKMAL N-ALPHA, N-PROTO0? 1470 2N,",/," RITH, RING, RIF, KINA, RINP = RESUNANCE INTEGRAL FOR ABSUROJ14BO 3PIION, N-GAMMA, FISSION, N-ALPHA, N-PROTON,","," RING = RITH 1021490 41 - FINA - FINP). RINA = HITH FINA. RINP = KITH *FINP. FINA, FO?1500 SIINP = FRACTION RESONAINCE N-ALPHA, N-PROTON." "I" SIGMEV, SIGFF, SIOP1510 GGNZN, SIGNAF, SIGNPF ; FAST CROSS SECTIONS (BERNS) FOR ABSORPTION,0?1520 7FISSION, N-2N, N-ALPHA, N-PKOTON,",/," SIGNEN = SIGMEV " 11 - FF021530 BNA - FFNP). SIGNAF = SIGMEV * FFNA. SIGIYPF = SIGMEV FFNP. FFN021540 9A, FFDP = FRACTION FAST N>ALPHA, N-P."1

$0 \supset 1550$

9007 FURMAT(" Y23, Y25, YOL, Y28, Y49 = FISSIUN YIELD (PERCENT) FROM 23021560 13-U, 235-U, 232-TH, 238-U, 239-PU.",/"W = CEAT PER UISINTEGRATI0 $>1570$ 2UN. FG = FRACTION OF HEAT IN GAMMAS UF EIVERGY GREATER THAN 0.2 MEO 21580 $3 V . " /, " O$ EFrECTIVE CRUSS SECTIONS FUR A VULUME AVERAGED THERMAL ILOZ1500 
470.876 EV) FLUX ARE AS FULLOWS.",/" IV_GAMMA - SIGNG \# THEKMO?1600 5 + RING * RES.", 11 " FISSION - SIGF THEKM + RIF * RES + SIGFOPI6IO 6F "FAST.", $10 X, " T H E R M=1 / V$ CURRECTION FOK THERMAL SPECTRUM AND TE0ZI6ZO 7MPERATURE."," " N-AN SIGNZN"FAST:",36X,"IRES = RATIU 0?1630 BOF RESONANCE FLUX PER LETUARGY UNIT TO THERMAL FLUX."1) 9008 FORMAT " N-ALPHA - SIGNA "THERM * RINA * RES * SIGNAF "FAST0?IG50 1.",7X,"FAST $=1.45 *$ RATIO OF FAST (GT 1.0 MEV) TO THERMAL FLUX "OS1660 2/" N-PROTON - SIGIYP * THERM + RINP * HES * SIGNPF *AST."I 02I670 9009 FORMATIIHO,59X, "REFERENCEG", $/$, HALF LAVES, DECAY SCHEMES, AND OZI6RO 1THERMAL POWER",/" C M LEOERER, J M HULLANDER, AND I PERLMAN "ITABOZ1690 2LE OF ISOTOPES - SIXTY EDATIONUII JOHN WILEY AIND SONS, INC 11967$) 11,071700$ 3/" B S DZHELEPOV AND L K PEKER "DDECAY SCHEMES OF RADIOACTIVE NUCOZITIO 4LEI" PERGAMMON PRESS (1961)"/,"D T GOLDMAN AND JAMES R ROSSER "O?1720 5"CHART OF THE NUCLIDESIII AINTH EDITION GENERAL ELECTRIC CO (JULY OPIT30 61966)"./"E D ARNOLD " "PROGRAM SPECTKA"1" APPENDIX A OF OHNL-3576 0>1740 7 (APRIL, 1964 ) 11 )

$021750^{\circ}$

9010 FORMAT " CROSS SECTIONS AND FLUX SPECTRA"," 8 E PRINCE "INEUTO?I760 IRON REACTION RATES IN THE MSRE SPECTRUMIII ORNL-4119, PP 79-83 (JULO?1770 2Y 1967,",/,"B E PRINGE "NEUTRON ENERGY SPECTRA IN MSRE AND MSBR"0?I780 3" ORNL-4191, PP 50-58 (DEE 1967)",\%" M D GOLUBERG ET AL "INEUTRUNOP1790 4 CROSS SECTIONS"II BNL-325. SECOND ED, SUPP NO 2 IMAY 1964 - AUG 19021800 566) ALSO EAKLIER EDITIONS"," H T KERR, UNPUDLISHED ERC COMPILAYIOZIRIO SUN (FEB 1968)",/." M K DRAKE "MA COMPILATION UF RESONANCE INTEGRALOPIBZO 7S" NUCLEUNICS, VOL 24, NU 8, PP 108-111 (AUG 1966)",/," BNWL STAFO?IB30 8F "'INVESTIGATION OF IY-2N CROSS SECTIONS"I BNWC-98, PP 44-98 (JUNEO21840 9 1965) 11)

9011 FORMAT (18A4,I3)

9012 FORMAT (1H1,20X,18A4)

021850

$0>1860$

021870

9013 FOKMAT," H ALTER AND C E NEBEK " "PRODUCTIUN QH H AND HE IN METALS O弓IIBBO 1UURING REACTOR IRRADIÄTIONIII J NUCL MATLS, VOL 16, PP 68-73 119651021890 2",/" L L BENNETT "URECOMMENDED FISSIUN PKODULT CHAINS FOR USE IN O?I900 3REACTOR EVALUATION STÜDIESUII ORNL-TM-165\% (SEFT 1966)")

9014 FORMAT " FISSION PKODUCT YIELDS",/," E MEEK AND B F KIDEK, "1OZI920 1 SUMMARY OF FISSION PRUDUCT YIELDS FOR U-235, Ū-238, PU-239, AND PUO2I930 2-24I AT THERMAL, FISSION SPECTRUM AND"/" I 4 MEV NEUTRUN ENERGIOPIO40 3ES $1 "$ APED-5398-A(REV.1, 104T. 1968)"/"S KATCOFF "IFISSION PRODICTOZI950 4 YIELDS FRUM NEUTRON INQUCËD FISSIONM" NUCLEONİCS, VOL 18. NO 11. 021960 $5(N O V$ 1960)" $" N$ D DUDEY "I REVIEW OF LOW-MASS ATOM PRODUCTION IN F0?I970 6AST REACTUKS" " ANL-74\$4, (APRIL 1968) ")

9016 FORMAT IHO.20X "ILIGHT ELEMENTS, MATERIALS OF IIVATTION PRODUCTS ", "O NUCL ULAM FËI FP " 2"FPI FT FA SIGNG FNGI SIGNZN FNZNI" 3" SIGNA SIGNP FG ABUNDANCE")

9018 FORMAT (1HO.10X,"THERM "F 10.5.5X,"RES= "F $10.5 \% 5 X, " F A S T=" F 10.5$. $1 / /, 1 X, " N E U T K O N$ SOURCE 15 (I) $10 ; 5 X) ; 5 X$, "NLI $P E=11[3$ )

9019 FORMATIIH0,36X,"FISSIYN PRODUCTS"\% $/ 110$ NUCL DLAM

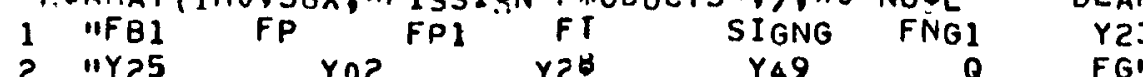
DLAM
Y23
FG')
OLAM 9020 FORMAT (1H0,36X,"FISSIUN PROODUCTS", , "10 NUCL

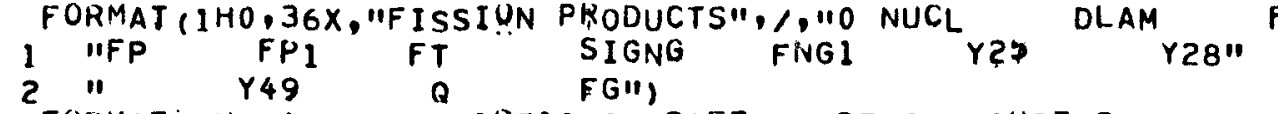

9021 FORMATSIH,A2,I3,AI,IPE 10,2, OP4FT,3,1PE10,2,0YF7,3, 1 IPSE, $10.2,0 P 2 F 7.3)$

9022 FURMATIIH, A2,I3,A1,1HEIO.2, OP4FT,3,1HEIO.2, 1 OPF 7,3,1P3E 10,2,0P2F.7.3)

9024 FURMAT $(1 H 0,32 X$, "ACTINIDE? AND THEIR DAUGUTERS",/

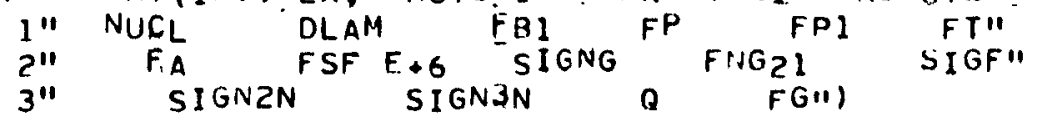

9026 FORMATIIH,A2,I3,A1,IPEI0.2, OP5F 7.3,6PF10.1,1HE10.2, 1 OPF $7.3,1 P 3 E 10.2,0$ PF $9.3, F 6.21$

9027 FURMAT ("OSUM OF YIELUS OF ALL FISSION PRONUCTS $=11,15 x, 1+3 E 9.2)$ 000660 022090 022100 0 ก0690 000700 000710 000720 000730 000740 0 กิ0750 0 กิ0760 0 กิ0770 0 กิ0780 022220 000800 000810 000820 0,0830 $0 \cap 0840$ 022200 
9028 FURMAI $(15,2 x, 1 P E) 10.3,3 x, E 10.3,5(2 x, E 10,3,3 x, 12) /(30 x, 5(2 x, E 10,3$, $13 x, 15) 11$

9029 FORMAT ("INON-ZEHO MATKIX ELEMENTS AND THEIR LUCATIONS"/

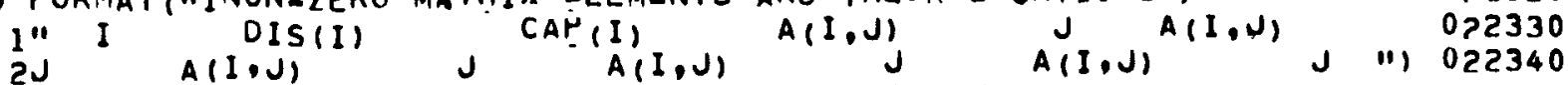

9030 FORMAT (63HOSUM OF YIELDS UF ALL FISSION PKODULTS

$1,5(E 9,2,1 X))$

9033 FURMATIIH,A2,I3,A1,1PE10.2,0P5F7.3,1PE10.2,0KF7,3,1PE10,2. 1 OPFI.3,1P2E10.2,0P2E7,3:F8.31

9034 FURMAT I $7, F 9.3,11,5 F 5,3,1$ RE9,2,OP2F5,3,F7.3,2E6,0)

9035 FOHMAT $(7 X, F 9.2,3 F 5,3, F, 9,2: 2 F 5,3, F 9,2,3 F 5,3,5 X, I 1)$

9036 FORMAT (20A4)

9037 FORMAT $(7 \times, 2 F 9.2, F 5,3,4 F 9,2, F 4.1, F 9,2,11)$

9038 FURMAT $(7 X, 2 F 9,2, F 5,3,5 F 9,2,4 X, 11)$

9039 FORMAT ("O WARNING. MUUT UF RANGE IN NUDATA, $="$ I5)

9040 FORMAT! $7 \times, F 9,2,3 F 8,6, F 6,2,2 F 3,1, F 9,2,3 F 5,3,5 X$, II)

9041 FORMAT ("O NON HAS EXCEEDEB 2500 , EQUAL TO "2IQ) END

\$DECK COLLECT

SUBROUTINE COLLECT (TMP, CWASTE, ITOT)

COMMON/EU/XTEMP $(800)$, XNEW $(10,800), B(800), \mathrm{V}(800)$

UIMENSION CWASTE (BOO)

IF (TMB.LT.1) RETURN

DO $10 \quad I=1$, ITOT

$B(I)=C W A S T E(I)$

$10 X \operatorname{TEMP}(I)=0.0$

CALL DFCAY (1,TMB, ITOT)

CALL TERM(TMB, I, ITOT)

CALL EOUIL (1. I TOT)

UU $20 \quad I=1$, I $10 T$

20 CWASTE $(I)=\operatorname{XNEW}(1,1) / T M B$

RETURN

END

-UECK STORAG

SUBROUTINE STORAG (TMH,CWASTE, ITOT)

COMMON,EQ/XTEMP $(800)$, XNEW $(10,000), A(800), 1(800)$

DIMENSION CWASTE IITOTL

IF (TMB:LT.1) RETURN

DELT $=T M B$

DO $10 \quad I=1$, I TOT

$B(I)=0.0$

$10 \quad X \operatorname{TEMP}(I)=$ CWASTE (I)

CALL DECAY $(1$, DELT, ITOI)

000860

0 กี0870

022420

022430

022440

000890

022460

022470

022480

$0 \supset 2490$

022500

022510

CALL TERM (TMB,1,ITOT)

CALL EQUIL (1,ITOT)

DO $20 \quad I=1$, I TOT

$20 \operatorname{CWASTE}(I)=\operatorname{XNEW}(1, I)$

KETURN

END

*DECK GLKDATT́

C PHOGRAM BLOCK DATA

BLOCK DATA ULKDATI

INTEGERELE ( 99$), S T A(2)$

COMMON LAUEL, ELE,STA

$0 ? 2550$

$0>2560$

022570

$0>2580$

$0 ? 2590$

$0>2600$

$0 ? 26>0$

$0 \supset 2630$

022640

022650

022660

022670

DATA ELE/" H", "HE" "LI","bE", B"," C", N"," O", F", "NE", "NA", "MO?ZRQO IG", "AL", "SI", P", "S", "CL", "AR","K", "CA", "SC", "T I", V"; "CR", "MNO?Z9OO 2", "FE", "CO", "NI", "CU", "ZN", "GA", "GE", "AS", "SE", "BR", "KR", "RB", "SR"OJ2910

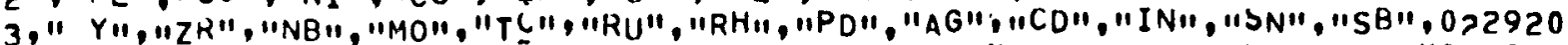
4"TE"," I", "XE", "CS", "QQA", "LA", "CE", "PR", "ND", "PM", "SM", "EU", "GD", "O Z2930 5TH", "DY", "HO", "ER", "TM", "Y甘", "LU", "HF", "TA", "W", "RE", "US", IR", "POPZ940 GI", "AU", "HG", "TL", "PB", "BI", "PO", "AT", "RN", "FK", "RA", "AC", "TH", "PAO 22950 7"," U", "NP", "PU", "AM", "CM", "RN", "CF", "ES"/

022960 DATA STA/" ".M"

022970 
END

- DEEK HALF

SUBROUTINE HALF (A,I)

C SUBROUTINE HALF CONVE

DIMENSION CIO) CONVERTS UALF-LIFE TO DECAY CUNSTANT (1/SKC)

022980

$0>2990$

023000

$0>3010$

DATA $C / 6.9315 E-01,1.1552 E-02,1.9254 E-04,8.0220 E-06,2.1965 E-08,0.0,0 ? 3030$

1

IF $(A .9 T .0 .0)$ GO TO 10

IF $(I . F 0.6)$ GO TO 20

$A=9.99$

RETURN

$10 \quad A=C(I) / A$

RETURN

$20 \quad A=0.0$

RETURN

END

*DECK NOAH

SUBROUTINE NOAH (NUCLI INAME)

C SUBROUTINE NOAH CONVESTS SIX

INTEGERNAME (3)

INTEGERELE (99), STA (2)

COMMON/LABEL/ ELE,STA

$I S=M O D(N U C L I, 10)+1$

$N Z=N U C L I / 10000$

$M W=N U C L I / 10-N Z \$ 1000$

NAME $\{1\}=E L E(N Z)$

NAME (2) $=M W$

$\operatorname{NAME}(3)=S T A($ IS)

RE TURN

END

$0>3040$

023050

023060

023070

023080

$0>3090$

$0>3100$

$0>3110$

$0>3120$

023130

$0>3140$

$0>3150$

023160

$0>3170$

023190

023100

023200

$0 ? 3210$

$0>3220$

$0 ? 3230$

023240

$0>3250$

023260

$0>3270$ 


\section{CHAPTER 4. DATA FOR RADIOACTIVE SOURCE TERM CALCULATIONS FOR PRESSURIZED WATER REACTORS (PWR's)}

This chapter lists the information needed to generate source terms for PWR's. The information is provided by the applicant and is consistent with the contents for the Safety Analysis Report (SAR) and the Environmental Report (ER) of the proposed pressurized water reactor. This information constitutes the basic data required in calculating the releases of radioactive material in liquid and gaseous effluents (the source terms). All data are on a per-reactor basis.

\subsection{GENERAL}

1. The maximum core thermal power (MWt) evaluated for safety considerations in the SAR.

Note: All the information required in calculating the releases should be adjusted to this power level.

2. The quantity of tritium released in liquid and gaseous effluents (Ci/yr per reactor).

\subsection{PRIMARY SYSTEM}

1. The total mass (1b) of coolant in the primary system, excluding the pressurizer and primary coolant purification system, at full power.

2. The average primary system letdown rate (gal/min) to the primary coolant purification system.

3. The average flow rate (gal/min) through the primary coolant purification system cation demineralizers.

Note: The letdown rate should include the fraction of time the cation demineralizers are in service.

4. The average shim bleed flow rate (gal/min).

\subsection{SECONDARY SYSTEM}

1. The number and type of steam generators and the carryover factor used in the evaluation for iodine and nonvolatiles.

2. The total steam flow rate $(1 \mathrm{~b} / \mathrm{hr})$ in the secondary system.

3. The mass of liquid in each steam generator (1b) at full power.

4. The primary-to-secondary system leakage rate (1b/day) used in the evaluation. 
5. Description of the steam generator blowdown purification system. The average steam generator blowdown rate $(1 \mathrm{~b} / \mathrm{hr})$ used in the evaluation.

6. The fraction of the steam generator feedwater processed through the condensate demineralizers and the DF's used in the evaluation for the condensate demineralizer system.

7. Condensate demineralizers

a. Average flow rate $(1 \mathrm{~b} / \mathrm{hr})$;

b. Demineralizer type (deep bed or powdered resin);

c. Number and size $\left(\mathrm{ft}^{3}\right)$ of demineralizers;

d. Regeneration frequency;

e. Indication whether ultrasonic resin cleaning is used and the waste liquid volume associated with its use; and

f. Regenerant volume (gal/event) and activity.

\subsection{LIQUID WASTE PROCESSING SYSTEMS}

1. For each liquid waste processing system, including the shim bleed, steam generator blowdown, and detergent waste processing systems, provide in tabular form the following information:

a. Sources, flow rates (gal/day), and expected activities (fraction of primary coolant activity) for all inputs to each system.

b. Holdup times associated with collection, processing, and discharge of all liquid streams.

c. Capacities of all tanks (gal) and processing equipment (gal/day) considered in calculating holdup times.

d. Decontamination factors for each processing step.

e. Fraction of each processing stream expected to be discharged over the life of the plant.

f. For demineralizer regeneration, provide time between regererations, regenerant volumes and activities, treatment of regenerants, and fraction of regenerant discharged. Include parameters used in making these determinations.

g. Liquid source term by radionuclide in $\mathrm{Ci} / \mathrm{yr}$ for normal operation, including anticipated operational occurrences. 
2. Provide piping and instrumentation diagrams (P\&ID's) and process flow diagrams for the liquid radwaste systems along with all other systems influencing the source term calculations.

\subsection{GASEOUS WASTE PROCESSING SYSTEM}

For the waste gas processing system, provide the following:

1. The method of stripping gases from the primary coolant, the volumes $\left(\mathrm{ft}^{3} / \mathrm{yr}\right)$ of gases stripped from the primary coolant, the bases for these volumes.

2. Description of the process used to hold up gases stripped from the primary system during normal operations and reactor shutdown. If pressurized storage tanks are used, include a process flow diagram of the system indicating the capacities $\left(\mathrm{ft}^{3}\right)$, number, and design and operating storage pressures for the storage tanks.

3. Describe the normal operation of the system, e.g., number of tanks held in reserve for back-to-back shutdown, fill time for tanks. Indicate the minimum holdup time used in the evaluation and the basis for this number.

4. If HEPA filters are used downstream of the pressurized storage tanks, provide the decontamination factor used in the evaluation.

5. If a charcoal delay system is used, describe this system and indicate the minimum holdup times for each radionuclide considered in the evaluation. List ${ }_{3}$ all parameters, including mass of charcoal ( $\mathrm{lb}$ ), flow rate $\mathrm{ft}^{3} / \mathrm{min}$ ), operating and dew point temperatures, and the dynamic adsorption coefficients for $\mathrm{Xe}$ and $\mathrm{Kr}$ used in calculating holdup times.

6. Provide piping and instrumentation diagrams (P\&ID's) and process flow diagrams for the gaseous radwaste systems along with other systems influencing the source term calculations.

\subsection{VENTILATION AND EXHAUST SYSTEMS}

For each building housing systems that contain radioactive materials, the steam generator blowdown system vent exhaust, gaseous waste processing system vent, and the main condenser air removal system, provide the following:

1. Provisions incorporated to reduce radioactivity releases through the ventilation or exhaust systems.

2. Decontamination factors assumed and the bases (include charcoal adsorbers, depth of charcoal beds, HEPA filters, and mechanical devices).

3. Release rates for radioiodine, noble gases, and radioactive particulates $(\mathrm{Ci} / \mathrm{yr})$, radioactive particulate size distribution, and the bases. 
4. Release point description, including height above grade, height above relative location to adjacent structures, relative temperature difference between gaseous effluents and ambient air, flow rate, velocity, and size and shape of flow orifice.

5. For the containment building, the building free volume $\left(\mathrm{ft}^{3}\right)$ and a thorough description of the internal recirculation system (if provided), including the recirculation rate, charcoal bed depth, operating time assumed, and mixing efficiency. Indicated the expected purge and venting frequencies and duration and continuous purge rate (if used). 


\section{LIQUID SOURCE TERM CALCULATIONAL PROCEDURE FOR REGENERANT WASTES FROM DEMINERALIZERS OTHER THAN CONDENSATE DEMINERALIZERS}

Often in PWR radwaste systems, demineralizers other than the condensate demineralizers may undergo regeneration, for example, the radwaste demineralizer in the dirty waste system. The PWR-GALE Code can calculate the liquid effluent resulting from periodic regeneration of non-condensate demineralizers by following the procedure outlined below.

1. Input to Cards $1-11$ and Cards $27-42$

A separate computer run for calculating the regeneration waste effluent from non-condensate demineralizers is required. Cards 1-11 should be filled out as indicated for the specific plant in Sections 1.5.2.1 through 1.5.2.11 of this report. Also Cards 27 through 41 may be left blank (except that values of 1.0 must be entered for Card 28 entries). Card 42 should be left blank.

2. Input to Cards 12-26

The only liquid source term data cards completed (Cards 12-26) should be the three card sets used in the input data for the stream in which the demineralizer to be regenerated is located. The remaining card sets should have a zero entered for the input flow rate.

a. Input Flow and Activity (Card 12, 15, 18, 21 or 24)

The input flow rate and input activity should be the average daily input flow rate and input activity processed through the demineralizer to be regenerated. For example, if the demineralizer to be regenerated is used to process a shim bleed waste stream, the total input flow rate might be 1440 gallons per day.

Note that it is not the flow rate and activity which is due to the regenerant waste which is entered, it is the normal flow rate and activity through the component to be regenerated which is entered.

b. Regeneration Frequency (Card 14, 17, 20, 23 or 26)

Enter the time between regenerations in days as the "collection time." If a regeneration frequency is stated by the applicant, it may be used; otherwise the following frequency may be used: 


\section{TABLE A-1}

Demineralizer Service

Primary Coolant Letdown

Boron Recovery System

Equipment Drain Wastes

Floor Drain Wastes

Steam Generator Blowdown

\section{Regeneration Frequency}

180 days

180 days

*

*

90 days

* Regeneration frequency is calculated by dividing the waste quantity (gallons) by the waste flow rate in gallons per day. The waste quantity is $25000 \mathrm{gal} / \mathrm{ft}^{3}$ times the volume in $\mathrm{ft}^{3}$ of resin for equipment drain waste and $2000 \mathrm{gal} / \mathrm{ft}^{3}$ times the volume in $\mathrm{ft}^{3}$ of resin for floor drain waste. The calculated values of 25,000 and $2,000 \mathrm{gal} / \mathrm{ft}^{3}$ of resin for the waste are based on $12,000 \mathrm{~g}$ $\mathrm{CaCO}_{3}$ ion exchange capacity per $\mathrm{ft}^{3}$ of resin and $5 \mu \mathrm{mho} / \mathrm{cm}$ and $50 \mu \mathrm{mho} / \mathrm{cm}$ average conductivity for equipment and floor drain liquid wastes.

By inputting the normal flow rate and activity in Item a and the regeneration frequency as the collection time in Item b the PWR-GALE Code will accumulate all of the activity processed through the demineralizer during its normal operation and decay the activity as a function of the time over which it was collected.

\section{c. Process Time and Fraction Discharged}

Use the same "process time" and "fraction discharged" as indicated for the stream in which the regeneration wastes are processed as indicated in Section 1.5.2.12.4 of this document.

d. Decontamination Factors (Card 13, 16, 19, 22 or 25)

The decontamination factors entered should consider radionuclide removal by the equipment used to process the regenerant wastes using the normal source term procedures of 1.5.2.12.2. In addition, the decontamination factors entered should be used to adjust the source term for the fraction of the activity in the process stream flowing through the demineralizer during normal operation which is not removed by the demineralizer. 
e. Sample Case

A demineralizer is used to process shim bleed waste and is to be regenerated. The normal flow rate for the demineralizer is $1440 \mathrm{gpd}$ and the activity is calculated in the PWR-GALE Code. The regenerant wastes will be processed through an evaporator and discharged.

Fill in the Cards $12-14$ in the following manner:

Card 12

Spaces 18-41 enter - shim bleed demin regen

Spaces 42-49 enter - 1440.0

$\underline{\text { Card } 13}$

The wastes will be processed through an evaporator which will provide the following DF's according to Table 1-4 of Section 1.5 .2 .12 .2 .

$$
\begin{aligned}
& \text { I }-10^{2} \\
& \text { Cs, Rb }-10^{3} \\
& \text { Others }-10^{3}
\end{aligned}
$$

While in operation, referring to Table 1-4 of Section 1.5.2.12.2 demineralizer DF's are:

$$
\begin{aligned}
& \mathrm{I}-10 \\
& \text { Cs, Rb }-2 \\
& \text { Others }-10
\end{aligned}
$$

Therefore, for "I" and "Others," 90\% of the activity processed through the demineralizer is removed by the resins and no adjustment is needed. Only $50 \%$ of the $\mathrm{Cs}$ and $\mathrm{Rb}$ in the waste stream is removed by the resins, however, so the DF entered for Cs should be adjusted. Thus, the DF's entered on Card 13 would be:

$$
\begin{aligned}
& I \quad 100.0 \\
& \text { Cs, Rb }-2000.0 \\
& \text { Others }-1000.0
\end{aligned}
$$

Card 14

Spaces 29-33 "Collection Time." Using the value from Table A-1 of 180 days for the regeneration frequency

Enter 180.0 days in spaces 29-33. 
Use the same "Process time" and "fraction discharged" as is indicated for the stream in which the regeneration wastes are processed as indicated in Section 1.5.2.12.4 of this report.

Note: If there is more than one stream for which non-condensate regenerant demineralizer is used, follow the same procedures explained under item A2 for the other stream or streams.

3. Components in Service

a. If the waste is processed through a component other than a regenerable demineralizer prior to processing by the regenerable demineralizer, the activity in the steam entering the demineralizer will be less than the activity entered as described above. To compensate for this difference, the DF's for the regenerant waste calculation should be adjusted in a manner similar to that described above. The product of the DF's should be used.

b. If two regenerable demineralizers are used in series, follow the procedure in a above. Adjust the DF for nuclides removed from the waste stream, by using the product of the DF's for two demineralizers in series, $i . e$. , consider the two demineralizers as one larger demineralizer.

4. Use of Computer Calculated Result

Combine the values printed out in the individual liquid source term columns for the system in which the demineralizer is being regenerated (not the adjusted total value) with the normal liquid source term run values. Do not use the adjusted total value from the right hand column since the source term run to which the regenerant waste run will be added has already been adjusted. 


\section{REFERENCES}

1. American National Standards Source Term Specification, ANSI N237-1976, American National Standards Institute.

2. Regulatory Guide 1.140, "Design, Testing, and Maintenance Criteria for Normal Ventilation Exhaust System Air Filtration and Adsorption Units of Light-Water-Cooled Nuclear Power Plants," March 1978, Office of Standards Development, U. S. Nuclear Regulatory Commission.

3. Letter from H. Till, Electric Power Research Institute, to J. Collins, NRC, March 8, 1978.

4. NUREG/CR-0140, "In-Plant Source Term Measurements at Ft. Calhoun Station, Unit 1," July 1978.

5. NUREG/CR-0715, "In-Plant Source Term Measurements at Zion Station," May, 1979.

6. NUREG/CR-1629, "In-Plant Source Term Measurements at Turkey Point Station - Unit 3 and 4," September, 1980.

7. Electric Power Research Institute Report EPRI NP-939, "Sources of Radioiodine at Pressurized Water Reactors," November, 1978.

8. Westinghouse Electric Corporation, WCAP-8253, "Source Term Data for Westinghouse Pressurized Water Reactors," July, 1975.

9. Letter from T. M. Anderson, Westinghouse Electric Corp. to J. Collins, NRC, April 17, 1979.

10. Combustion Engineering, CENPD-67, Rev. 1, "Iodine Decontamination Factors During PWR Steam Generation and Steam Venting," J. A. Martucci, November, 1974.

11. Combustion Engineering, CENPD-67, Addendum 1P, "Iodine Decontamination Factors During PWR Steam Generation and Steam Venting," November 1974.

12. Westinghouse Electric Corporation, WCAP-8215, "Steam Side Iodine Transport Study at Point Beach Unit No. 1 of Wisconsin Electric Power Company," October 1973.

13. General Electric Company, Figure 5 of Draft Report, "Fission Product Transport Measurements at Brunswick - 2," C. Lin and H. Kenitzer (to be published).

14. NUREG-0017, "Calculation of Releases of Radioactive Materials in Gaseous and Liquid Effluents from Pressurized Water Reactors (PWR-GALE Code)," April 1976. 
15. NUREG-0016, Rev. 1, "Calculation of Releases of Radioactive Materials in Gaseous and Liquid Effluents from Boiling Water Reactors (BWRGALE Code)," January 1979.

16. Pilgrim 2 Preliminary Safety Analys is Report (PSAR) (Docket No. 50-471), Appendix 11E, Amendment 12, November 1974.

17. Letter from K. Seyfrit, Technical Assistance Branch, AEC, Regulatory Operations, to G. Lainas, Containment Systems Branch, AEC, Licensing "PWR Purging and Venting Experience," September 3, 1974.

18. NUREG-75/087, "U. S. Nuclear Regulatory Commission Standard Review Plan," Section 6.2.4, "Containment Isolation System," Rev. 1, November 1978.

19. Rochester Gas and Electric Corporation, "Radioactivity in the Containment Building Atmosphere of Ginna Station," A. R. Piccot, 1971.

20. Nuclear Containment Systems, Incorporated, NCS-1101, "Dynamic Adsorption Coefficient and Its Application for Krypton-Xenon Delay Bed Design," J. L. Kovach, Draft, November 1971.

21. L. R. Michaels and N. R. Horton, "Improved BWR Offgas Systems," 12th Air Cleaning Conference, San Jose, California, August 1972.

22. W. E. Browning et al., "Removal of Fission Product Gases from Reactor Offgas Streams by Adsorption," ORNL Central Files Number 59-6-47, June $11,1959$.

23. H. J. Schroeder et al., "Offgas Facility at the Gundremmingen Nuclear Power Plant," Journal for Nuclear Engineers and Scientists," No. 5, May 1971, pp. 205-213.

24. Letter from Kerndraftwerk Lingen GMBH to Peter Lang, North American Carbon, "Gas Delay System at KWL," December 30, 1970.

25. General Electric Company, NED0-10751, "Experimental and Operational Confirmation of Offgas System Design Parameters," C. W. Miller, proprietary report, October 1972.

26. Letter from J. L. Kovach, Nuclear Containment Systems, Inc., to V. Benaroya, AEC, "Gas Delay Systems," December 1, 1971.

27. D. P. Siegwarth et al., "Measurement of Dynamic Adsorption Coefficients for Noble Gases on Activated Carbon," 12th Air Cleaning Conference, August 1972.

28. General Electric Co., NEDO-20116, "Experimental and Operational Confirmation of Offgas System Design Parameters," C. W. Miller, October 1973. 
29. ANSI/ANS 55.6-1979, "American National Standard Liquid Radioactive Waste Processing System for Light Water Reactor Plants," American National Standards Institute, April 1979.

30. NWT 133-1, "OTSG Secondary Water Chemistry Study," Nuclear Water and Waste Technology, March 1978.

31. NWT 133-2, "OTSG Secondary Water Chemistry Study," Nuclear Water and Waste Technology, June 1978.

32. NUREG/CR-0143, "The Use of Ion Exchange to Treat Radioactive Liquids in Light-Water-Cooled Nuclear Power Plants," August 1978.

33. NUREG/CR-0142, "The Use of Evaporation to Treat Radioactive Liquids in Light-Water-Cooled Nuclear Power Plants," September, 1978.

34. NUREG/CR-0141, "The Use of Filtration to Treat Radioactive Liquids in Light-Water-Cooled Nuclear Power Plants," September 1978.

35. "A Study of Reverse 0smosis Applicability to Light Water Reactor Radwaste Processing," J. Markind, T. Van Tran, November 1978.

36. W. R. Greenway et al., "Treatment of Radioactive Steam Generator Blowdown," 33rd Annual Meeting, International Water Conference of the Engineers' Society of Western Pennsylvania, October 24-26, 1972.

37. C. Kunz et al., "C-14 Gaseous Effluent From Pressurized Water Reactors," CONF-741018, Symposium on Population Exposures, Proceedings of the Eighth Midyear Topical Symposium of Health Physics Society, Knoxville, Tennessee, October 21-24, 1974, pp. 229-234.

38. Westinghouse Electric Corporation, WCAP-7702, "Interim Report on Study of Iodine Transport in PWR Steam Systems," May, 1971.

39. Letter from T. M. Anderson, Westinghouse Electric Corp., to R. Bangart, NRC, November 8, 1979.

40. Letter from J. J. Barton, Metropolitan Edison Co., to J. Collins, NRC, December 4, 1979.

41. U.S.E.P.A., EPA-520/5-76-003, "Radiological Surveillance Studies at the Oyster Creek BWR Nuclear Generating Station," June 1976.

42. "In-Plant Source Term Measurements at Prairie Island Nuclear Generating Station." To be published as a NUREG document.

43. "In-Plant Source Term Measurements at Rancho Seco Station," NUREG/ CR-2348, October 1981. 